\title{
A REGULAÇÃO DA CONTRATAÇÃO INTERNACIONAL DE TRANSFERÊNCIA DE TECNOLOGIA - PERSPECTIVA DO DIREITO DE PROPRIEDADE INDUSTRIAL, DAS NORMAS CAMBIAIS E TRIBUTÁRIAS E DO DIREITO CONCORRENCIAL
}

Tese apresentada à Faculdade de Direito da Universidade de São Paulo para obtenção do Título de Doutor em Direito

Área de Concentração: Direito Comercial Orientador: Prof. Titular Dr. Calixto Salomão Filho

São Paulo

2010 


\section{AUTORIZO A REPRODUÇÃO E DIVULGAÇÃO TOTAL OU PARCIAL DESTE TRABALHO, POR QUALQUER MEIO CONVENCIONAL OU ELETRÔNICO, PARA FINS DE ESTUDO E PESQUISA, DESDE QUE CITADA A FONTE.}

\section{FICHA CATALOGRÁFICA}

Franco, Karin Klempp

A regulação da contratação internacional de transferência de tecnologia - perspectiva do direito de propriedade industrial, das normas cambiais e tributárias e do direito concorrencial / Karin Klempp Franco; orientador Calixto Salomão Filho - São Paulo, 2010. 240 p.

Tese (Doutorado - Programa de Pós-graduação em Direito Comercial) - Faculdade de Direito da Universidade de São Paulo.

1. Transferência de tecnologia. 2. Contratos de transferência de tecnologia. 3. Regulação. 4. Políticas públicas. 5. Política industrial e tecnológica. 
FOLHA DE APROVAÇÃO

KARIN KLEMPP FRANCO

A REGULAÇÃO DA CONTRATAÇÃO INTERNACIONAL DE TRANSFERÊNCIA DE TECNOLOGIA - PERSPECTIVA DO DIREITO DE PROPRIEDADE INDUSTRIAL, DAS NORMAS CAMBIAIS E TRIBUTÁRIAS E DO DIREITO CONCORRENCIAL

Tese apresentada à Faculdade de Direito da Universidade de São Paulo para obtenção do Título de Doutor em Direito. Área de Concentração: Direito Comercial Orientador: Prof. Titular Dr. Calixto Salomão Filho

Aprovado em:

Banca examinadora 
Para Isadora Penkal Franco 
Agradecimentos:

Agradeço ao Prof. Dr. Calixto Salomão Filho, pelo incentivo e apoio ao tema, apoio a mim e pela paciência, constantes. Agradeço ao MaxPlanck-Institut für ausländisches und internationales Privatrecht, na figura do Prof. Dr. Dr. Dr. h.c. mult. Klaus J. Hopt, pela acolhida e oportunidade de pesquisa. Muito obrigada à amiga Katharina Krapp, pela estadia em sua casa em Munique quando ainda elaborava o projeto de pesquisa, permitindo o acesso à biblioteca do Max-PlanckInstitut für Geistiges Eigentum, Wettbewerbs- und Steuerrecht. Agradeço com carinho especial aos meus pais, que me ensinaram que o estudo nos torna independentes. Ao querido Rogério Emílio. Aos amigos que contribuíram com a tese e me deram apoio, principalmente ao dedicado Vicente Oliveira, à sempre prestativa Floriana Postel, à Maria Schweinberger e à Minica. 


\section{LISTA DE ABREVIATURAS E SIGLAS}

\begin{tabular}{|c|c|}
\hline ADN & Ato Declaratório Normativo \\
\hline AN & Ato Normativo \\
\hline BACEN & Banco Central do Brasil \\
\hline BIT & Bilateral Investment Treaties \\
\hline CADE & Conselho Administrativo de Defesa Econômica \\
\hline CST & Coordenação Geral do Sistema de Tributação \\
\hline CUP & Convenção da União de Paris para a Proteção à Propriedade Industrial \\
\hline DIRTEC & Diretoria de Contratos de Tecnologia e Outros Registros (INPI) \\
\hline FIRCE & Gerência de Fiscalização e Registro de Capitais Estrangeiros \\
\hline FTC & Federal Trade Commission \\
\hline GATT & Acordo Geral sobre Pautas Aduaneiras e Comércio \\
\hline GATS & Acordo Geral sobre o Comércio de Serviços \\
\hline IEDI & Instituto de Estudos para o Desenvolvimento Industrial \\
\hline INPI & Instituto Nacional da Propriedade Industrial \\
\hline MDIC & Ministério do Desenvolvimento, Indústria e Comércio Exterior \\
\hline MEFP & Ministério da Economia, Fazenda e Planejamento \\
\hline $\mathrm{MF}$ & Ministério da Fazenda \\
\hline NAFTA & North American Free Trade Agreement \\
\hline OCDE & Organização para a Cooperação e Desenvolvimento Econômico \\
\hline OMC & Organização Mundial do Comércio \\
\hline ONU & Organização das Nações Unidas \\
\hline PICE & Política Industrial de Comércio Exterior \\
\hline PITCE & Política Industrial, Tecnológica e de Comércio Exterior \\
\hline PDP & Política de Desenvolvimento Produtivo \\
\hline PPA & Plano Plurianual \\
\hline SBDC & Sistema Brasileiro de Defesa da Concorrência \\
\hline SISBACEN & Sistema de Informações do Banco Central \\
\hline $\mathrm{SRF}$ & Secretaria da Receita Federal \\
\hline SUMOC & Superintendência da Moeda e do Crédito \\
\hline TOT CODE & Conferência das Nações Unidas sobre um Código de Conduta em \\
\hline & Transferência de Tecnologia, no âmbito da UNCTAD \\
\hline TRIPS & $\begin{array}{l}\text { Acordo Sobre Aspectos dos Direitos de Propriedade Intelectual Relacionados } \\
\text { ao Comércio }\end{array}$ \\
\hline UNCTAD & Conferência das Nações Unidas para o Comércio e Desenvolvimento \\
\hline US DoJ & United States Department of Justice \\
\hline
\end{tabular}




\section{RESUMO}

A transferência internacional de tecnologia é operação que serve como base para o desenvolvimento tecnológico. Muito além da dicotomia desenvolvimento autóctone versus importação de tecnologia, verificamos que a importação de tecnologia é, também, geradora de parte das condições precedentes para o desenvolvimento de inovação localmente. Componente-chave de qualquer processo de transferência de tecnologia é a efetiva transferência de habilidades e know-how intangível que assegurem a capacidade produtiva. $\mathrm{O}$ canal de transferência de tecnologia não é uma forma fácil de construir capacidade de inovação. Por meio deste, as conseqüências da transferência de tecnologia serão determinadas pelos objetivos gerais das corporações que contratam, os quais certamente não englobam a disseminação da tecnologia para potenciais concorrentes. Dentro do contexto de conflito tecnológico norte-sul ainda existente, a harmonização do direito da concorrência e da propriedade intelectual em torno do interesse coletivo concentra-se justamente na administração da intenção dos países detentores da tecnologia de manter o seu monopólio e acesso restrito à tecnologia e o dos países receptores de terem amplo acesso e utilização da tecnologia. A política de intensificação da transferência de tecnologia internacional depende não somente de políticas regionais e internacionais, mas também de políticas nacionais. É preciso analisar caminhos viáveis para as políticas dentro da moldura nacional e internacional existente. A industrialização brasileira orientou-se no sentido de gerar capacidade produtiva com adoção de padrões tecnológicos relativamente atrasados e imposição de elevadas barreiras à entrada, impactando significativamente a capacidade do país de gerar, transferir e introduzir inovações tecnológicas. A regulação da transferência de tecnologia que a acompanhou tinha como vetores principais a substituição de importações paralelamente a controles fiscais e cambiais dos pagamentos das contratações, como forma de promover o equilíbrio da balança de pagamentos do país. Esta permanece em vigor, com alterações mínimas. Ao Governo cabe delinear de forma mais clara em sua política industrial o tipo e maneira de controles que pretende exercer sobre a importação de tecnologia para o país, e com qual finalidade. Adicionalmente, é preciso promover uma harmonização dos vários diplomas legais incidentes na operação para que expressem coerência entre si. A coerência será atingida na medida em que se escolham os vetores definidores da regulação de forma consistente. A regulação deve concentrar-se na absorção da técnica pela mão-de-obra local, sem desestimular o fornecedor estrangeiro. Ambos objetivos serão atingidos com a (i) matização da regulação na área tributária e cambial e a (ii) promoção de maior interatividade entre a regulação pela propriedade industrial e o direito concorrencial, que devem focar nos termos das contratações. Quanto à política da concorrência, é preciso distinguir entre uma política de concorrência baseada somente em inovação e aquela baseada em disseminação da inovação. Quando se foca somente na inovação e se impede a disseminação, esquece-se de que o bônus que se concede hoje à inovação implicará um preço no futuro. Uma política de concorrência com a intenção de promover a disseminação e absorção de tecnologia não pode ser tarefa para as autoridades da área concorrencial, somente.

Palavras-chave: Transferência de tecnologia. Contratos de transferência de tecnologia. Regulação. Políticas públicas. Política industrial e tecnológica. Propriedade intelectual. Propriedade industrial. Importação de tecnologia. Inovação. Concorrência. Concorrênciainovação e concorrência-disseminação. 


\section{ABSTRACT}

The international transfer of technology is an operation that serves as a basis for technological development. Well beyond the contrast indigenous development versus importation of technology, the importation of technology also generates preconditions for the development of local innovation. A key component of any transfer of technology process is the effective transfer of expertise and intangible know-how that ensure the production capacity. The transfer of technology vehicle is not a simple form of building innovation capacity. Through it, the consequences of the transfer of technology are determined by the overall purposes sought by the companies that convene this and certainly does not cover the dissemination of the technology to potential competitors. Within the context of the northsouth technological conflict that still exists, streamlining of antitrust law and of intellectual property law considering the public interest lays precisely on the management of the intention of the countries that own the technology to sustain their monopoly and restrict the access to the technology and the intention of the acquiring countries to have broad access and use of the technology. The policy of incrementing transfer of international technology depends not only on regional and international policies, but also on national policies, being necessary to analyze viable courses for the policies in the existing national and international framework. The Brazilian industrialization was guided in the direction of generation of production capacity adopting international standards that were relatively obsolete and by imposing obstacles to imports, substantially affecting the country's capacity to generate, transfer and adopt new technologies. The technology transfer regulations that accompanied it had as its main pillars the replacement of imports and tax and currency exchange controls over the payments of the agreements to stabilize the country's foreign trade deficit. This continues to exist, with minimal changes. It is incumbent on the Government to clearly outline in its industrial policy the type and form of the control that it intends to use in the importation of technology into Brazil and with what purpose. Further, it is necessary to harmonize the several statutes that apply to the operation so that they reflect coherency among each other. Coherence shall be attained upon selecting the vectors that define the regulation in a consistent manner. The regulation should concentrate on the absorption of the know-how by the local workers, but without discouraging the foreign supplier. Both goals would be met upon (i) softening the regulation under the tax and exchange aspects, and (ii) fostering greater interaction between the regulation in the intellectual property and antitrust laws areas, which should focus on the contractual clauses. As regards the antitrust policy, it is necessary to distinguish between an antitrust policy that is based solely on innovation and that which is based on the dissemination of the innovation. When only innovation is focused and dissemination is hindered, the bonus that is now being conferred to innovation and that will have a toll in the future is ignored. An antitrust policy that is intended to foster the dissemination and absorption of technology cannot be a task borne only by the antitrust authorities.

Key words: Technology transfer. Transfer of technology agreements. Regulation.

Governmental policies. Industrial and technological policy. Intellectual property. Industrial property. Importation of technology. Innovation. Competition. Innovation-oriented competition and dissemination-oriented competition. 


\section{ZUSAMMENFASSUNG}

Die Operation des internationalen Technologietransfers ist eine der Grundlagen für die technische Entwicklung. Die Feststellung, dass der Import von Technologie auch einen Teil der Voraussetzungen für die lokale Entwicklung der Innovation schafft, geht weit über die Dichotomie der 'eigenständigen Entwicklung' versus 'Technologieimport' hinaus. Eine Schlüsselkomponente jedes Technologietransferprozesses ist die effektive Übertragung von Fähigkeiten und know-how, durch die die Produktionskapazität sichergestellt wird. Der Technologietransfer ist keine einfache Form des Aufbaus von Innovationskapazität, da sich die Konsequenzen des Technologietransfers an den allgemeinen Zwecken des Unternehmens orientieren, das diesen Technologietransfer vertraglich vereinbart. Die Verbreitung der Technologie an potenzielle Konkurrenten gehört sicher nicht zum Unternehmenszweck. Im Kontext des noch existierenden Nord-Süd-Technologiekonflikts konzentrieren sich die Harmonisierung des Wettbewerbsrechts und des Rechtes des geistigen Eigentums um das kollektive Interesse herum auf die Verwaltung der Absichten der beteiligten Nationen. Die Länder, Inhaber der Technologie sind, geht es darum, ihr Monopol zu wahren und den Zugang zur Technologie zu beschränken und den Empfängerländer um möglichst umfassenden Zugang und Nutzung der Technologie. Die Politik der Intensivierung des internationalen Technologietransfers hängt nicht nur von regionaler und internationaler, sondern auch von nationaler Politik ab. Es sind innerhalb des existierenden nationalen und internationalen Rahmens gangbare Wege zu analysieren. Die brasilianische Industrialisierung bewegte sich bisher in Richtung der Erzeugung von Produktionskapazität auf relativ verspäteter Technologiestandards und die Auferlegung hoher Handelsschranken und beeinträchtigte dadurch erheblich die Fähigkeit des Landes zur Erzeugung, Übertragung und Einführung technischer Innovationen. Hauptvektoren der Regelung des Technologietransfers waren die Ersetzung der Importe und die gleichzeitige Steuer - und Devisenkontrolle der Zahlungen für den Technologietransfer als Form der Förderung des Gleichgewichts der Zahlungsbilanz des Landes. Diese Regelung gilt nach wie vor, wenn auch mit minimalen Änderungen. Es ist Aufgabe der Regierung, in ihrer Industriepolitik klar abzugrenzen, welche Typen und Arten der Kontrollen sie beim Import von Technologie nach Brasilien auszuüben beabsichtigt und welcher Zweck mit der Kontrolle verfolgt werden soll. Darüber hinaus müssen die für diese Operationen einschlägigen gesetzlichen Vorschriften harmonisiert werden, um sie zueinander kohärent zu machen. Diese Kohärenz wird durch die konsistente Wahl der die Regelung definierenden Vektoren erreicht. Die Regulierung muss sich auf die Absorption der Technik durch lokale Fachkräfte konzentrieren, ohne den ausländischen Lieferanten den Anreiz zum Technologietransfer zu nehmen. Beide Ziele werden erreicht durch (i) Differenzierung der Regelung im Steuer- und Devisenrecht und (ii) Förderung größerer Interaktivität zwischen den Regelungen der gewerblichen Schutzrechte und des Wettbewerbsrechts, die sich auf die Bestimmungen der Technologietransferverträge konzentrieren müssen. Was die Wettbewerbspolitik betrifft, so ist zwischen einer nur auf Innovation und auf einer auf der Verbreitung der Innovation beruhenden Wettbewerbspolitik zu unterscheiden. Liegt der Schwerpunkt nur auf der Innovation und wird die Verbreitung verhindert, wird vergessen, dass der Bonus, den man heute der Innovation einräumt, seinen Preis in der Zukunft zu zahlenden Preis hat. Eine Wettbewerbspolitik zur Förderung der Verbreitung und der Absorption der Technologie kann nicht nur Aufgabe der Behörden des Wettbewerbsbereichs sein.

Schlüsselbegriffe: Technologietransfer. Technologietransferverträge. Regulierung. Öffentliche Politik. Industrie- und Technologiepolitik. Sonstige Schutzrechte. Gewerbliche Schutzrechte. Technologieimport. Innovation. Wettbewerb. Wettbewerb-Innovation und WettbewerbVerbreitung. 


\section{SUMÁRIO}

INTRODUÇÃO

CAPÍTULO I - TECNOLOGIA, TRANSFERÊNCIA DE TECNOLOGIA E O CONFLITO

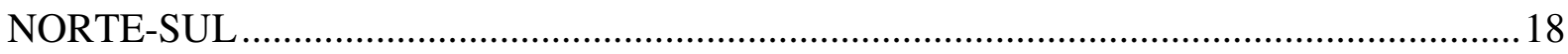

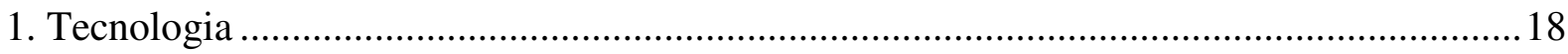

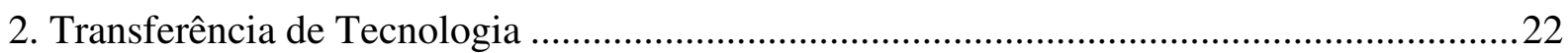

3. Tecnologia, Know-how e Segredo de Negócio - A Proteção pelo Direito Brasileiro da Propriedade Industrial.

4. Aspectos do Direito dos Contratos / Natureza Jurídica da Transferência de Tecnologia ....31 4.2. Caracterização da Natureza Jurídica do Contrato: Prestação de Serviços, Licença ou Cessão

5. Conflito Tecnológico Norte-Sul

6. A Tutela da Transferência de Tecnologia e da Proteção ao Segredo de Negócio no Direito Internacional

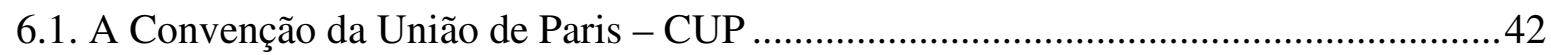

6.2. O Código Internacional de Conduta em Transferência de Tecnologia - TOT Code ....44

6.3. O TRIPS - Acordo Sobre Aspectos dos Direitos de Propriedade Intelectual

Relacionados ao Comércio

7. Necessidade do Foco da Regulação Nacional na Absorção de Tecnologia Localmente .....53

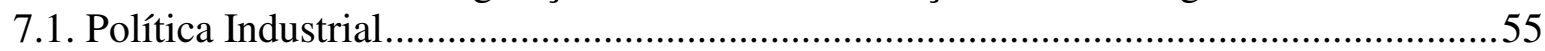

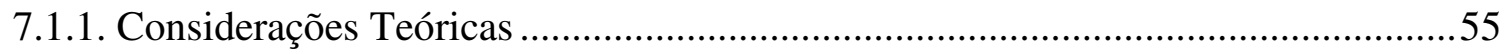

7.1.2. Histórico da Política Industrial Recente ....................................................................57

7.2. Aplicação da Política Industrial de Absorção e Difusão de Tecnologia nos Contratos de

Transferência de Tecnologia

CAPÍTULO II - FUNDAMENTOS JURÍDICOS E REGULATÓRIOS DA ATUAÇÃO DO INPI NO REGISTRO DOS CONTRATOS DE TRANSFERÊNCIA DE TECNOLOGIA ....61

1. Contexto Histórico e Econômico da Regulação dos Contratos de Transferência de

Tecnologia.

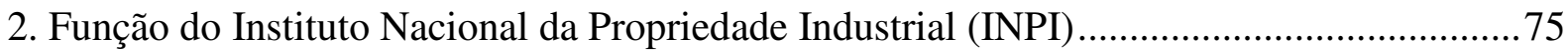

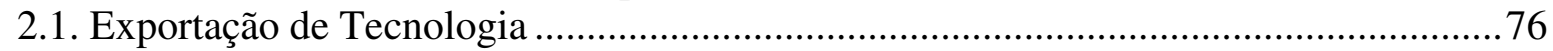

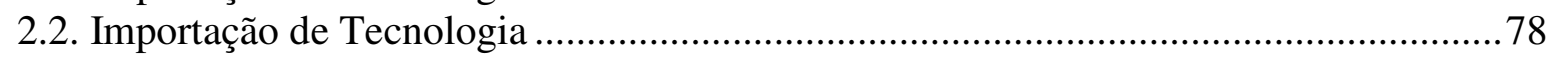

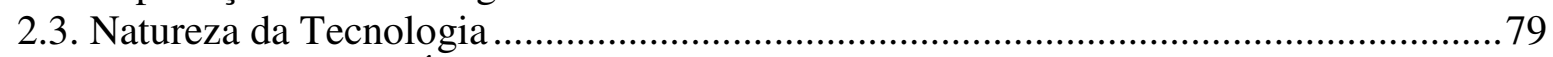

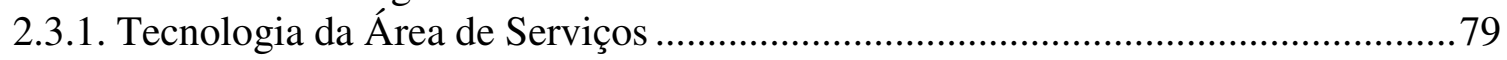

2.3.2. Programas de Computador e Serviços Correlatos .................................................. 82

2.3.3. Tecnologia Não Protegida pela Propriedade Industrial - Ausência de

Confidencialidade 


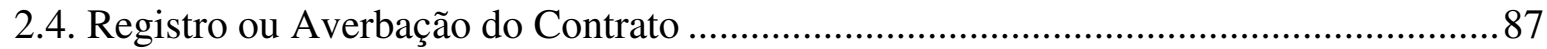

2.4.1. Natureza Jurídica e Função do Registro ………………………………………........ 87

2.4.1.2. Produção de Efeitos Perante Terceiros ..........................................................99

2.4.2. Conteúdo do Certificado de Averbação................................................................92

2.5. Análise da Legislação que Confere Suporte às Atividades do INPI .............................93

2.5.1. Evolução Legislativa .............................................................................................95

3. Breve Delineamento e Valoração de Aspectos da Legislação Tributária Aplicável aos Contratos de Transferência de Tecnologia e de sua Interpretação pelo INPI ...........................102

3.1. Classificação das Operações de Transferência de Tecnologia pela Legislação Tributária

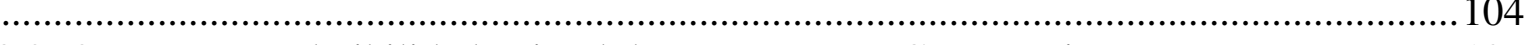

3.2. O Foco na Dedutibilidade Fiscal dos Pagamentos Contratuais....................................107

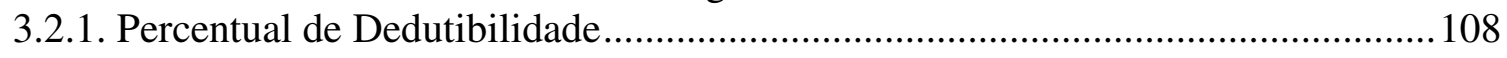

3.2.2. Prazo de Dedutibilidade .................................................................................112

3.2.3. Concomitância de Pagamentos por Marcas e Transferência de Tecnologia ........113 3.3. A Atuação do INPI em Relação a Aspectos Tributários dos Contratos de Transferência

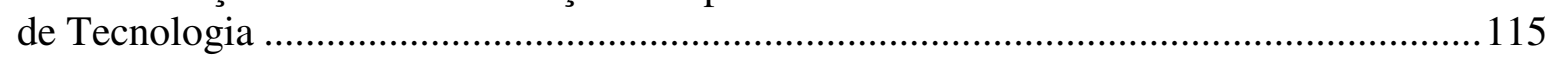

4. Os Contratos de Transferência de Tecnologia e a Legislação Cambial ................................120

4.1. Limitação de Remessas entre Empresas do Mesmo Grupo Econômico ……………...120

4.2. A Atuação do INPI em Relação a Aspectos Cambiais dos Contratos de Transferência

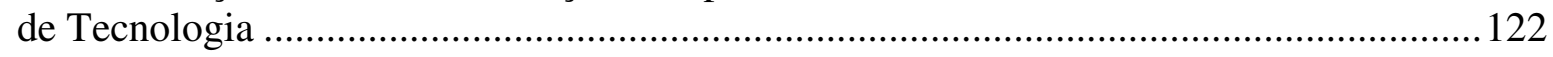

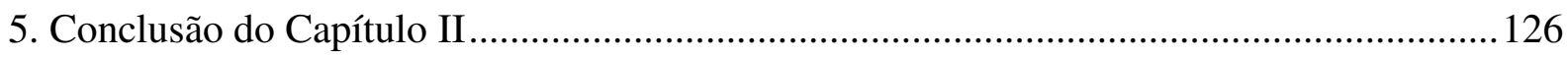

CAPÍTULO III - A INSTRUMENTALIZAÇÃO DA DIFUSÃO E ABSORÇÃO TECNOLÓGICA POR MEIO DA PROTEÇÃO E ESTÍMULO À CONCORRÊNCIA NO DIREITO DE PROPRIEDADE INTELECTUAL ………….............................................. 130

1. Direito de Propriedade Intelectual, Direito da Concorrência e a Política Industrial nos

Contratos de Transferência de Tecnologia ...

1.1. Interação e jogo de interesses em torno destes três elementos na transferência de

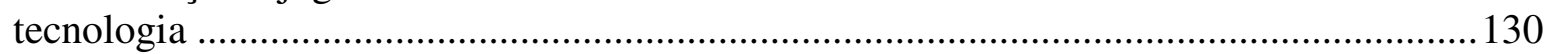

1.2. A intersecção entre o direito concorrencial e o direito de propriedade intelectual. ....136

1.3. Especificidades quanto ao contrato de transferência de tecnologia ...............................144

1.4. A absorção e a difusão de tecnologia delineada nas cláusulas contratuais. .................146

2. As Práticas Restritivas em Contratos de Licença no TRIPS ...................................................153

3. A Regulação Administrativa dos Contratos de Transferência de Tecnologia sob a Perspectiva Concorrencial na Europa, sob o Tratado de Roma ………………………….....158

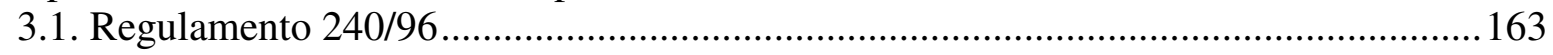

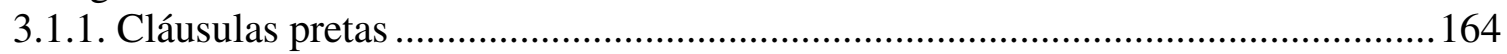

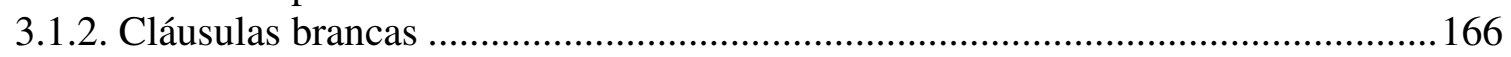

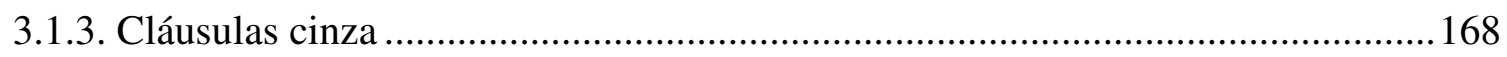

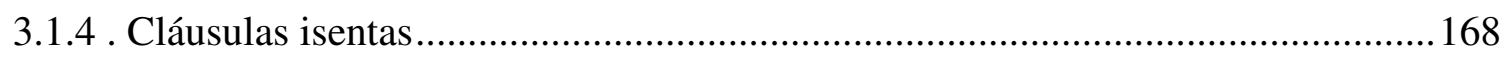

3.1.5. Críticas e mudanças para o novo Regulamento..................................................... 170

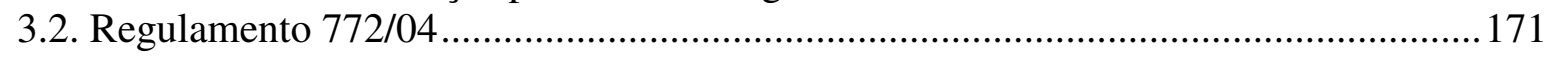

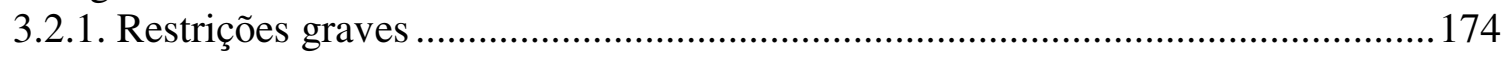

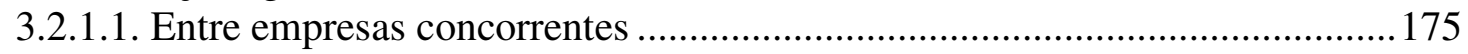

(i) Fixação de preços..........................................................................................175 


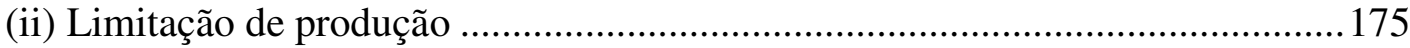

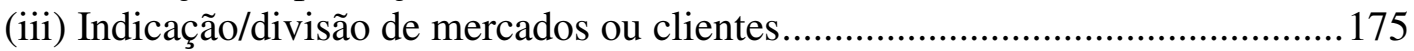

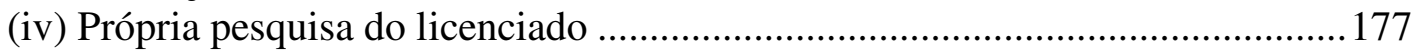

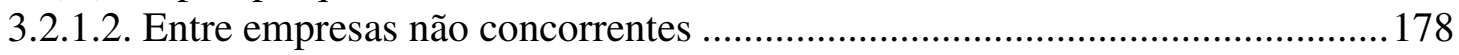

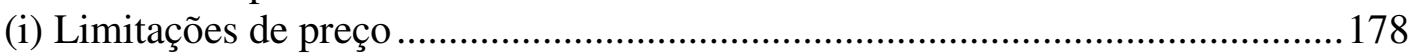

(ii) Restrições ao território e círculo de clientes do licenciado .............................. 178

(iii) Restrições ao território e círculo de clientes do licenciante ...........................179

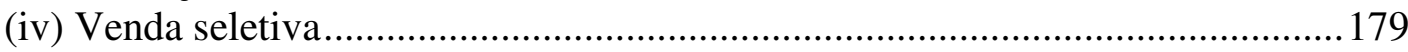

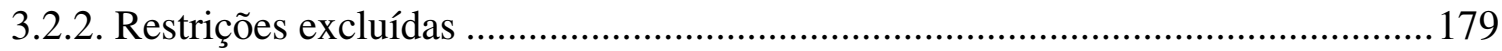

(i) Retrolicença e dever de cessão ..................................................................... 179

(ii) Proibição de contestação dos direitos do licenciante em juízo..........................180

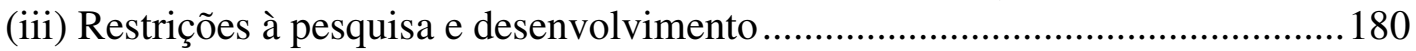

3.3. A Aplicação do Direito Concorrencial pela Comissão Européia ................................ 181

4. Direito da Concorrência e da Propriedade Industrial como Instrumento de Política Pública na Revisão dos Contratos de Transferência de Tecnologia no Brasil ................................... 182 4.1. A Aplicação de Disposições do Direito Concorrencial a Contratos de Transferência de

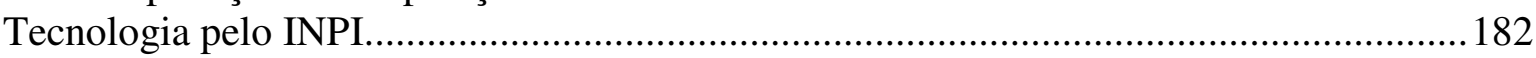
4.2. A Aplicação da Lei 8.884/94 ao Contrato de Transferência de Tecnologia................. 192 4.3. Recomendação de Criação de Regulação Administrativa Específica para Contratos de Transferência de Tecnologia

4.3.1. Análise da experiência recente internacional dos países em desenvolvimento.... 199

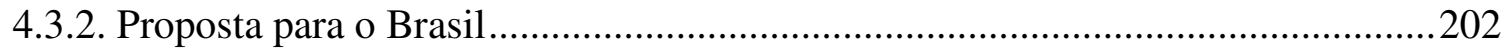

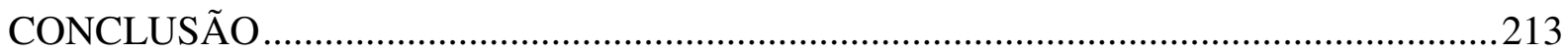

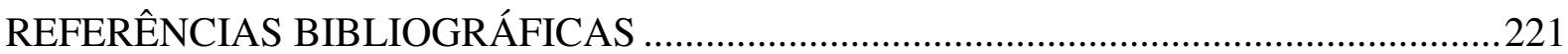




\section{INTRODUÇÃO*}

Deter o conhecimento da técnica, promover o aprendizado tecnológico e a inovação são peças essenciais para o desenvolvimento social e econômico e para a inserção do país no competitivo comércio internacional, em época de economias inter-relacionadas e interdependentes e de insuficiência do desenvolvimento econômico voltado para o mercado interno, somente.

O senso comum infere e estudos efetivamente demonstram que países com alto índice tecnológico têm números promissores na área econômica e social e estão inseridos de forma mais equilibrada nas trocas do comércio internacional. A tecnologia - não isolada nos círculos científicos, mas aplicada na atividade econômica do país - é capaz de gerar um círculo virtuoso, desenvolvendo mão-de-obra, gerando empregos, renda, receitas e exportações.

O Brasil possui um parque tecnológico diversificado, herança da sua industrialização planificada ao longo dos anos cinqüenta. Possui tecnologias avançadas em alguns setores, mas também carências tecnológicas graves em áreas importantes.

\footnotetext{
* Utilizaremos neste trabalho os conceitos de propriedade intelectual e propriedade industrial de forma distinta. A propriedade industrial está contida no conceito de propriedade intelectual, que a abrange.

Propriedade intelectual conforme o Decreto 75.541/75 (Convenção de Estocolmo que institui a Organização Mundial da Propriedade Intelectual 'OMPI') compreende:

“Art. $2^{\circ}$ Definições. Para os fins da presente Convenção, entende-se por: [...]

Inciso VIII 'propriedade intelectual', os direitos relativos:

às obras literárias, artísticas e científicas,

às interpretações dos artistas intérpretes e às execuções dos artistas executantes, aos fonogramas e às emissões de radiofusão;

às invenções em todos os domínios da atividade humana,

às descobertas científicas,

aos desenhos e modelos industriais,

às marcas industriais, comerciais e de serviço, bem como às firmas comerciais e denominações comerciais,

à proteção contra a concorrência desleal e todos os outros direitos inerentes à atividade intelectual nos domínios industrial, científico, literário e artístico.

No Brasil, o termo propriedade industrial é legalmente definido. Conforme a Lei 9.279/96:

“Art. 20 A proteção dos direitos relativos à propriedade industrial, considerado o interesse social e o desenvolvimento tecnológico e econômico do País efetua-se mediante:

I - concessão de patentes de invenção e de modelo de utilidade

II - concessão de registro de desenho industrial

III - concessão de registro de marca

IV - repressão às falsas indicações geográficas; e

V - repressão à concorrência desleal."
} 
O conhecimento não é absolutamente estanque e independente. Cada inovação evolui, em maior ou menor grau, da técnica já existente, do denominado estado da técnica mundial. A difusão desse conhecimento é em parte quase que automática pela própria interligação da economia. Porém, há um papel importante a ser desenvolvido por cada Estado para tornar essa difusão do conhecimento global mais intensa localmente.

Há técnicas que são mantidas em segredo ou em monopólio de poucos, justamente pelo alto valor econômico que incorporam. Há, também, técnicas que podem ser aprendidas indiretamente, incorporadas em um equipamento ou uma prestação de serviços. É a transferência de tecnologia que vai permitir o aperfeiçoamento da técnica em território nacional, que por sua vez permitirá o avanço do parque tecnológico brasileiro, seja por meio do desenvolvimento autóctone de inovações, seja por outras operações de transferência de tecnologia do exterior.

A transferência de tecnologia é, portanto, a base para o desenvolvimento tecnológico. Muito além da dicotomia desenvolvimento autóctone versus importação de tecnologia, verificamos que a importação de tecnologia é, também, geradora de parte das condições precedentes para o desenvolvimento de inovação localmente. Por meio dela é que um país alcança o estado da técnica mundial que lhe permitirá avançar tecnologicamente.

Ressalte-se que a transferência de tecnologia não opera em um vácuo, existem fatores complementares que ajudam a implementá-la de forma efetiva. Estes são a política governamental e regulação, mas também a qualidade da infra-estrutura de produção, a estrutura de mercado, a qualidade de instituições de pesquisa e desenvolvimento, bem como de sua infra-estrutura, e a capacidade de colaboração recíproca e de interação entre essas instituições.

O contraponto das operações de transferência de tecnologia são as importações de produtos acabados industrializados. É justamente a importação que se pretende afastar, posto que incapaz de gerar ou de gerar na mesma intensidade os efeitos sinérgicos de desenvolvimento de mão-de-obra, geração de empregos, renda, receitas e exportações que as operações de transferência de tecnologia.

A tecnologia importada é transferida de muitas maneiras. Uma delas é o investimento estrangeiro direto. A aplicação de capital estrangeiro em subsidiárias 
(controladas por empresa estrangeira) ou mesmo em uma nova empresa criada em parceria com um sócio local é operação que implica transferência de tecnologia. Ela pode não estar em primeiro plano, como negócio jurídico principal, mas ocorrerá quase que automaticamente da operação, envolvendo tanto tecnologia de produção, quanto gerencial e administrativa.

Outra forma de transferência de tecnologia internacional são os contratos de desenvolvimento conjunto de inovações. Há a transferência de tecnologia de uma parte a outra para que juntas consigam gerar algo novo. A união de esforços, seja a união de técnicas, ou de técnica e infra-estrutura, é que gerará a sinergia para a inovação.

Transferência de tecnologia internacional ocorre também em contratos de compra e venda de maquinários e equipamentos importados (inclusive militares). A absorção acontece de forma subsidiária, refere-se aos conhecimentos inferidos quando da instalação, operação, conserto e manutenção destes bens.

A prestação de serviços técnicos também implica a transferência de tecnologia. Trata-se de transferência de tecnologia no corpo-a-corpo, de um técnico a outro, quando da realização dos serviços. Há transferência de conhecimentos por meio dos relatórios gerados, dos ajustes efetuados, do treinamento realizado.

$\mathrm{E}$, finalmente, há a transferência de tecnologia internacional em contratos que envolvam direitos de propriedade intelectual. A tecnologia vem revestida de um direito de propriedade ou de um uso exclusivo instituído pela relação contratual, no caso dos segredos de negócio.

Ciente da importância da transferência de tecnologia, o Brasil desenvolveu uma regulação específica com o intuito de monitorá-la e direcioná-la aos interesses nacionais. Como é comum nos países de menor desenvolvimento tecnológico, herança de uma política de substituição de importações, a regulação foca consistentemente em aspectos cambiais e tributários.

No presente trabalho, pretendemos comprovar que a regulação da contratação internacional de transferência de tecnologia deve concentrar-se na absorção da técnica pela mão-de-obra local, sem desestimular o fornecedor estrangeiro. Ambos os objetivos serão atingidos com a (i) matização da regulação na área tributária e cambial e (ii) promoção de 
maior interatividade entre a regulação pela propriedade industrial e o direito concorrencial, que focarão nos termos das contratações, promovendo a difusão do conhecimento.

O primeiro argumento que corrobora a tese é o de que uma técnica só é absorvida quando há um preparo para tanto. Enquanto cabe ao Estado prover soluções para a educação básica da mão-de-obra nacional, a regulação estatal dos termos da contratação também ajudará se focar em permitir o mais amplo acesso da mão-de-obra local à técnica e assegurar sua efetiva implementação na atividade produtiva local. A regulação é necessária, não há como deixar a absorção da tecnologia pela mão-de-obra local dependente de questões comerciais. As questões comerciais podem, e devem, objetivar o fomento da transferência de tecnologia internacional. Seu foco é outro. Com exceção da política desenvolvida pela Coordenação de Imigração do Ministério do Trabalho e Emprego a partir de 1991 para aprovação da renovação de visto de técnicos estrangeiros sob contratos de cooperação técnica, não há um ponto sequer da regulação atual que se concentre em criar as condições de efetivo acesso da mão-de-obra local à técnica e de promoção da sua efetiva implementação na atividade produtiva local.

O segundo argumento principal da tese é o de que a regulação existente para essas operações é inadequada porque se baseia em pontos atualmente irrelevantes para a economia do país e tem como conseqüência o desestímulo das operações de transferência de tecnologia. Desenvolvida a partir da década de cinquienta, a regulação está baseada na necessidade de evitar-se a remessa desenfreada de pagamentos ao exterior e coibir-se a distribuição disfarçada de lucros entre empresas coligadas, regulando-se assim a balança de pagamentos do país. Praticamente não se renovou nos anos oitenta e noventa, tendo se tornado inadequada no contexto econômico atual. Ao invés de promover operações de transferência de tecnologia para o Brasil, a regulação atual acaba por desestimulá-las. Ademais, seu aperfeiçoamento legislativo faz-se necessário, a fim de legitimar a implementação de política industrial de absorção de tecnologia pela mão-de-obra local (conforme o primeiro argumento supra exposto) e extirpar a orientação jurisprudencial negativa à regulação que está despontando.

O terceiro argumento a corroborar a tese é o de que uma regulação eficaz, que incentive a transferência de tecnologia promovendo a absorção pela mão-de-obra local conseguirá se estabelecer com base na proteção à propriedade intelectual e na preservação da concorrência. Isso pode ocorrer por meio de ingerência do Estado nos termos contratuais pactuados. 
Desenvolveremos a tese da seguinte maneira:

No Capítulo I analisaremos o que se entende sob o conceito de tecnologia e sua transferência. Faremos uma delimitação das categorias de operação de transferência de tecnologia que serão objeto da presente tese. Concluiremos que se trata de matéria com tratamento multidisciplinar. Verificaremos o tratamento dado a essas operações internacionalmente e o jogo de interesses internacional (conflito norte-sul) que essas operações envolvem. Justificaremos a importância das operações de transferência de tecnologia para o alcance do estado da técnica mundial pelo Brasil. Mostraremos que isso somente será possível com uma regulação que foque na absorção da técnica pela mão-de-obra local.

O Capítulo II trará uma exposição crítica da atual regulação das operações de transferência de tecnologia no país, implementada principalmente pelo Instituto Nacional da Propriedade Industrial - INPI, que aplica a legislação nas áreas de propriedade intelectual, tributária, cambial e concorrencial a esses contratos. Apontaremos o contexto histórico do seu surgimento e demonstraremos sua inadequação à realidade atual, pois que desestimula a transferência de tecnologia internacional para o Brasil.

No Capítulo III apresentaremos o tratamento que poderá ser conferido às operações de transferência de tecnologia internacional sob a ótica do direito concorrencial, relacionado-o com o tratamento com base no direito de propriedade intelectual. Utilizaremos como fundo da argumentação o modelo de regulação europeu. 


\title{
CAPÍTULO I - TECNOLOGIA, TRANSFERÊNCIA DE TECNOLOGIA E O CONFLITO NORTE-SUL
}

\begin{abstract}
Ao aceitar a idéia central de Adam Smith de que é o trabalho que cria a riqueza, Marx soube perceber que o valor econômico pode também ser criado pelo trabalho intelectual, pela tecnologia. Nos Grundrisse für eine Kritik der politischen Ökonomie, observou que 'à medida que a grande indústria se desenvolve, a criação da verdadeira riqueza depende menos do tempo e da quantidade de trabalho empregado do que da ação de fatores postos em movimento no curso do trabalho, e cuja poderosa eficácia é incomensuravelmente maior que o tempo de trabalho imediato que custa a produção; ela [a criação da riqueza] depende muito mais do estado geral da ciência e do progresso tecnológico, que é uma aplicação da ciência à produção.'
\end{abstract}

Fábio Konder Comparato ${ }^{1}$

No capítulo I analisaremos o que se entende sob o conceito de tecnologia e sua transferência. Faremos uma delimitação das categorias de operação de transferência de tecnologia que serão objeto da presente tese. Concluiremos que se trata de matéria com tratamento multidisciplinar. Verificaremos o tratamento dado a essas operações internacionalmente e o jogo de interesses internacional (conflito norte-sul) que estas operações envolvem. Justificaremos a importância das operações de transferência de tecnologia para o alcance do estado da técnica mundial pelo Brasil. Mostraremos que isto somente será possível com uma regulação que foque na absorção da técnica pela mão-de-obra local.

\section{Tecnologia}

Etimologicamente, a palavra tecnologia deriva dos radicais gregos technéltékhné/tekhno (habilidade, destreza, ofício, arte, ciência) e logos/logía (linguagem, razão, conhecimento, ensinamento, ciência, palavra, proposição) ${ }^{2}$.

${ }^{1}$ COMPARATO, F. Ética. São Paulo: Companhia das Letras, 2006, p. 342.

${ }^{2}$ Duden - Deutsches Universalwörterbuch. Conforme Maria Helena Pereira Dias: "Entre os gregos combinar os termos téchne (arte, destreza) e logos (palavra) orientava o discurso sobre o sentido e a finalidade das artes técnica e arte no mundo grego possuíam apenas uma pequena distinção, a téchne não era uma habilidade qualquer e requeria o uso de certas regras. Heródoto, o primeiro a definir o termo téchne, apresenta-o como um "saber fazer de forma eficaz" e, segundo Platão, seu sentido diz respeito à "realização material e concreta de algo". A natureza inteligente do homem permite-lhe transformar pela téchne a realidade natural em uma realidade artificial com a finalidade de sua subsistência e proteção. Conforme Aristóteles, a téchne é superior à 
No senso comum, o termo tecnologia é definido como "conjunto de conhecimentos, especialmente princípios científicos, que se aplicam a um determinado ramo de atividade"3 ou, ainda, "processo de conhecimento sistematizado que se aplica na elaboração de tarefas artísticas, científicas ou industriais" ${ }^{» 4}$. No ordenamento jurídico brasileiro, assim como em muitos outros, tais como o alemão, o termo tecnologia não possui definição legal. O que leva a um desentendimento sobre a abrangência do conceito, qual acabou por gerar uma miríade de definições pelos intérpretes do direito; isso ocorre não somente no âmbito da ciência do direito, mas também na ciência econômica e da engenharia, por exemplo 5 .

O primeiro ponto de conflito importante na caracterização da tecnologia diz respeito à natureza do conhecimento. Indaga-se se somente o conhecimento das ciências técnicas no sentido estrito implicaria uma tecnologia, excluindo-se conhecimentos da área de administração e dos negócios. Parte da doutrina entende que, na transmissão destes últimos, estar-se-ia lidando com uma forma de instrução e ensino, mas não de transferência de tecnologia ${ }^{6}$. Referidos conhecimentos constituiriam corriqueiramente aspectos comportamentais humanos, habilidades que não circulam, pois que não se incorporariam a bens. $\mathrm{O}$ entendimento que nos parece correto é o de que tecnologia constitui a totalidade dos conhecimentos utilizados para a produção e comércio de bens e serviços ${ }^{7}$. Esse conceito

experiência, mas inferior ao raciocínio. Entretanto demanda este último. Em relação ao conhecimento, enquanto a epistéme era para os gregos um conhecimento teórico a téchne era um conhecimento prático, com vistas a um objetivo concreto" (DIAS, M. H. P. Hipertexto, O Labirinto Eletrônico, Uma Experiência Hipertextual. Tese de Doutoramento na Faculdade de Educação da Universidade Estadual de Campinas, Unicamp, 2000. Disponível em <http://www.libdigi.unicamp.br/document/?code=vtls000197594>. Acesso em 15/10/2009, Capítulo Escrita e Tecnologia).

${ }^{3}$ Dicionário da Língua Portuguesa Novo Aurélio Século XXI, 1999.

${ }^{4}$ Vocabulário Enciclopédico de Tecnologia Jurídica e de Brocardos Latinos. Rio de Janeiro: Forense, 1997.

${ }^{5}$ Para uma discussão sobre os diferentes conceitos de tecnologia no campo econômico, vide: ELIAS, L. A.; CASSIOLATO, J. E. O Balanço de Pagamentos Tecnológicos Brasileiro: Evolução do Controle Governamental e Alguns Indicadores. In: VIOTTI, E. B.; MACEDO, M. de M. (org.). Indicadores de Ciência, Tecnologia e Inovação no Brasil. Campinas: Ed. Unicamp, 2003, p. 278 e ss.

${ }^{6}$ Vide, entre outros, FUNKE, G. Technologietransfer in internationalen Corporate Joint Ventures: eine Untersuchung zu dem Wirtschaftsordnungsrecht im Hinblick auf patentrechtlich nicht geschützte Technologie. Europäische Hochschulschriften: Reihe 2, Rechtswissenschaft, Band 2382. Frankfurt/M., Berlin, Bern, New York, Paris, Wien: Peter Lang, 1998, p. 11 e ss.

${ }^{7}$ Neste sentido, HEUBEL, A. Technologietransfer durch internationale Unternehmenskooperationen - Eine vertragstheoretische Analyse Law and Economics, Band 23. München: Beck, 1994, p. 22 e ss. A definição de José Roberto Dromi parece-nos a mais plausível, para quem a tecnologia compreende algo a mais e algo a menos que a palavra "técnica". Algo a menos, pois quando se menciona tecnologia retira-se o círculo do conhecimento relativo ao direito, às artes e à pedagogia. Algo a mais, pois tecnologia refere-se não somente a técnicas de engenharia, mas também a métodos de negócios, especialmente na área de organização da produção e de marketing. DROMI, J. R. Derecho y Tecnologia. Revista de Direito Público, São Paulo, 1989(55), p. 152. Na área econômica, John K. Galbraith entende a tecnologia como ferramenta para aplicação do conhecimento a tarefas práticas, forçando a divisão e subdivisão das tarefas, a fim de obter um melhor desempenho. Esta divisão e subdivisão forçada, constante e cada vez mais intensa é um dos marcos representativos da indústria moderna - 
recepciona também o fato de as economias modernas serem crescentemente economias do setor de serviços e do conhecimento ${ }^{8}$. Alguns autores entendem a tecnologia ou a técnica comercial como a técnica de segunda geração, sendo a técnica industrial a técnica de primeira geração 9 .

Entendemos, também, que a tecnologia pode referir-se tanto a produtos e serviços como a processos em si mesmos. Mas, a fim de adquirir o status de uma tecnologia é preciso que a técnica consiga abstrair-se de seu criador e formar um corpo único e independente de instruções. Para ser considerada tecnologia, é preciso que a técnica esteja sistematizada ${ }^{10}$.

Ainda sobre a delimitação do conceito tecnologia, discute-se se bens materiais podem ser considerados tecnologia ${ }^{11}$. A tecnologia, como conhecimento, necessariamente constitui-se de informações. Ela pode estar corporificada em um bem ou suporte, mas existe independentemente dele. A questão que se coloca nessa hipótese é a da forma de transferência ou de comunicação da tecnologia e não a da sua natureza. Tecnologia pode ser comunicada de maneira abstrata - incluída abstratamente em um documento - e também de forma aplicada, corporificada em um maquinário. Nesse último caso, por exemplo, a leitura das instruções de

GALBRAITH, JOHN K. O Novo Estado Industrial. Tradução da $3^{\text {a }}$ edição por Leônidas Gontijo Carvalho. São Paulo: Abril Cultural, 1982, p. 191.

${ }^{8}$ Conforme STIGLITZ, J. Development Policies in a World of Globalization. Paper presented on the occasion of the fiftieth anniversary of the Brazilian Economic and Social Development Bank (BNDES). Rio de Janeiro, September 2002, p. 21. Nota-se que o conhecimento da área administrativa, gerencial e de marketing foi e ainda é discriminado na prática normativo-legislativa. Exemplificativamente, o INPI (Instituto Nacional da Propriedade Industrial) não registra contratos referentes a tecnologias nesta área, a menos que se revistam do formato de franquia. Já a lei alemã de repressão às práticas de limitação da concorrência, GWB - "Gesetzt gegen Wettbewerbsbeschränkungen", continha disposições sobre contratos de licença de direitos de propriedade industrial (§ 20) e dispunha que o mesmo aplicava-se a contratos relativos a know-how técnico (§ 21). Já o know-how não técnico, ficava sujeito subsidiariamente às regras gerais da lei (e não ao $§ 20$ ). Com a paulatina adaptação da lei às regras concorrenciais do direito comunitário europeu, esta diferenciação foi revogada e atualmente a GWB faz menção expressa às diretivas e regulamentos europeus para grupos e categorias de contratos $[\S 2(2)]$.

${ }^{9}$ MARTINEK, M. Moderne Vertragstypen, Band II: Franchising, Know-how Verträge, Management- und Consultingverträge. Munique: Beck, 1992, p. 214 e ss., justifica esta proteção de segunda geração por haver: "(...) um avanço do conhecimento, aplicável racionalmente, e que é relevante diferencial competitivo para as empresas". (nossa versão do alemão).

${ }^{10}$ O TOT Code reconhece esta necessidade de sistematização: "Transferência de tecnologia sob este Código é a transferência de conhecimento sistematizado para a fabricação de um produto, para a aplicação de um processo ou para a prestação de serviços e não se estende a transações envolvendo a mera compra ou a mera locação de bens. (...)". Capítulo 1, item 1.2. A Conferência das Nações Unidas sobre um Código de Conduta em Transferência de Tecnologia nasceu em 1974, conforme analisaremos ainda neste capítulo no subitem de convenções internacionais. O texto atualizado do código, versão de 1985, está acessível no seguinte endereço eletrônico: http://stdev.unctad.org/compendium/themes/coc.htm - último acesso em 07/05/2009.

${ }^{11}$ Parte da doutrina entende que o termo "tecnologia" abrange o conhecimento técnico imaterial e também bens corpóreos, tais como instalações, plantas fabris, desenhos técnicos, descrições procedimentais, máquinas e equipamentos, vide: HÖLZLWIMMER, G. Produkthaftungsrechtliche Risiken des Technologietransfers durch Lizenzverträge. Tese de Doutoramento na Ludwig-Maximiliams-Universität zu München. Munique, 1993, p. 8. 
montagem, funcionamento e manutenção do maquinário deixarão claro qual tecnologia nele está corporificada, pois que sistematizada ao redor de um maquinário.

A análise econômica da informação que constitui uma tecnologia permite concluir que se trata, por natureza, de um bem público, livremente disponível e acessível. As características principais do bem econômico informação seriam, assim, a não-rivalidade e o fato de não ser excludente. $O$ uso da informação por uma pessoa não diminui a disponibilidade de uso por outros. Além disso, pela facilidade e baixo custo de transmissão, pode se tornar muito oneroso eliminar a possibilidade de terceiros aprenderem e utilizarem a informação. O terceiro incorrerá custos ao retransmitir esta informação, mas o custo principal é o de sua criação e produção. No instante em que o titular vende a informação a um terceiro, o terceiro torna-se um competidor potencial do detentor original.

Como consequiência, quanto maior a quantidade de pessoas que têm acesso ou conhecimento de uma determinada informação, menor o seu valor econômico. Aquela informação que todos conhecem ou todos da área técnica conhecem não possui um valor econômico em si mesma. Se qualquer um pode se utilizar da informação, detê-la ou desenvolvê-la e colocá-la em circulação não conferiria uma vantagem competitiva ou de mercado. Ou seja, o valor econômico da informação é inversamente proporcional à quantidade de pessoas que a conhecem. Logo, a circulação da informação tecnológica sem qualquer tipo de interferência de regulação tenderá a fornecer um nível deficiente ou muito reduzido de inovações técnicas para a sociedade. Trata-se de típico exemplo de falha de mercado. $^{12}$

Automaticamente se inquire, então, sobre a possibilidade de se apropriar a informação consistente da tecnologia. Trata-se de processo que aumenta o valor da tecnologia para seu titular ao criar escassez por meio de acesso restrito ao seu conteúdo. Para tanto, fazse necessária uma intervenção governamental.

Juridicamente, bens com valor de mercado geralmente recebem a tutela do direito de propriedade ou uma forma de proteção indireta que garanta o controle do seu uso. A atribuição de um direito de propriedade ou de uso exclusivo a uma informação é alcançada por meio do direito da propriedade intelectual. Já a proteção indireta, por meio de contrato ou

${ }^{12}$ Vide: BARBOSA, C. R. Propriedade Intelectual Enquanto Informação e os Aspectos Econômicos dos Bens Intelectuais. Tese de Doutoramento. Universidade de São Paulo, Faculdade de Direito, 2007, sobre a questão da propriedade intelectual enquanto informação. 
de ilícitos civis e criminais, pode vir contida tanto na lei de propriedade industrial, bem como na legislação genérica civil, contratual e criminal.

Assim, a tutela jurídica da informação por meio da propriedade intelectual baseiase em considerações de ordem econômica e política, a concessão desta proteção é uma escolha do Governo. ${ }^{13}$

\section{Transferência de Tecnologia}

A tecnologia circula. Assim como não existe uma definição de tecnologia, também não há uma lista de operações de transferência de tecnologia. A fim de verificar se há uma transferência de tecnologia ou não, é preciso analisar a operação, concretamente. Somente se caracterizará uma transferência de tecnologia se houver uma intenção de fornecer o conhecimento. Caso contrário, estar-se-á diante de uma difusão de tecnologia, e não de uma transferência. ${ }^{14}$ A difusão de tecnologia é um benefício adicional que a transferência de tecnologia pode trazer para a economia receptora da tecnologia. A introdução de uma nova tecnologia em um país pode ter efeitos que se espalham pela economia como um todo, dependendo das políticas adotadas pelo país receptor - i.e. obrigatoriedade de treinamento de mão-de-obra local, utilização de empresas locais de engenharia e consultoria, entre outros. ${ }^{15}$ Analisaremos a questão da difusão tecnológica nos Capítulos II e III.

Para que haja uma transferência de tecnologia, não é necessário haver um contrato específico ou uma indicação específica da operação de transferência de tecnologia. A transferência de tecnologia geralmente ocorre por meio de duas categorias principais: operações em que a transferência de tecnologia é uma conseqüência do objetivo principal e operações em que a transferência de tecnologia é o foco mesmo da operação.

\footnotetext{
13 António Carlos dos Santos e outros analisam que com a percepção da crescente valia econômica da informação, os agentes econômicos têm defendido a introdução nos sistemas jurídicos de modalidade de proteção direta da informação, um direito de propriedade sobre a informação. DOS SANTOS, A. C.; GONÇALVES, M. E.; MARQUES, M. M. L. Direito Econômico. 4. ed. Coimbra: Almedina, 2001, p. 472 e ss.

${ }^{14}$ Guido Funke esclarece em detalhe a questão da difusão tecnológica. (FUNKE, G. Technologietransfer in internationalen Corporate Joint Ventures: eine Untersuchung zu dem Wirtschaftsordnungsrecht im Hinblick auf patentrechtlich nicht geschützte Technologie, p. 15).

${ }^{15}$ UNCTAD - United Nations Conference on Trade and Development. Transfer of Technology. United Nations Publication. New York and Geneva, 2001. Disponível em: <http://www.unctad.org/en/docs//psiteiitd28.en.pdf>. Acesso em: 20/01/2010, p. 7.
} 
Até mesmo o Código Internacional de Conduta em Transferência de Tecnologia (“TOT Code") não apresenta um conceito exaustivo do termo ${ }^{16}$ :

Capítulo 1, item 1.2. - Operações de transferência de tecnologia são arranjos entre partes, (...) particularmente nos seguintes casos:

(a) A cessão, venda e licenciamento de todas as formas de propriedade industrial, exceto marcas de comércio, serviço e nomes empresariais quando não sejam parte de uma operação de transferência de tecnologia;

(b) $\mathrm{O}$ fornecimento de know-how e expertise técnica na forma de estudos de viabilidade, planos, diagramas, modelos, instruções, guias, fórmulas, desenhos de engenharia básica ou detalhada, especificações e equipamentos para treinamento, serviços envolvendo pessoal de assessoria técnica ou administrativa, e treinamento de pessoal;

(c) $\mathrm{O}$ fornecimento de conhecimento técnico necessário para a instalação, operação e funcionamento de maquinário e equipamento e projetos turn-key;

(d) A prestação de conhecimento técnico necessário para adquirir, instalar, e usar maquinário, equipamento, bens intermediários e/ou matérias-primas que tenham sido adquiridas por compra, aluguel ou outros meios;

(e) O fornecimento de conteúdo tecnológico em operações industriais e de cooperação técnica (nossa versão para o português, grifos nossos).

Essa definição interessa-nos, pois já delineia o conteúdo tecnológico das operações, inclusive aquelas que não têm a transferência de tecnologia como objeto principal. Assim, ela não menciona compra e venda de maquinário e equipamentos, mas a prestação de conhecimento técnico necessário para tanto [itens (c) e (d) acima]. Conclui-se que onde há tecnologia pode haver a transferência de tecnologia, desde que o receptor tenha condições de aprender a técnica por meio da operação. Isso poderá ocorrer, exemplificativamente, por meio de uma empresa comum que é formada [item (e)], ou na construção de plantas e linhas de produção [itens (b) e (c)]. É preciso distinguir entre a roupagem das operações comerciais e seu conteúdo, a fim de conseguir determinar quando há transferência de tecnologia ou não ${ }^{17}$. Conforme a importância econômica que a tecnologia vem adquirindo, é cada vez mais comum que dentro dessas operações encontrem-se cada vez mais contratos de fornecimento de tecnologia, contendo pagamentos autônomos, adicionais ao do negócio principal.

A presente pesquisa, entre as várias espécies de operação de transferência de tecnologia expostas, foca na análise dos contratos internacionais de transferência de tecnologia propriamente ditos, quais sejam, os contratos que têm por objeto principal a comunicação de tecnologia. Estes estão contidos nos itens (a) e (b) acima.

\footnotetext{
${ }^{16}$ O texto atualizado do código, versão de 1985, está acessível no seguinte endereço eletrônico: http://stdev.unctad.org/compendium/themes/coc.htm - último acesso em 07/05/2009.

${ }^{17}$ Guido Funke distingue entre vários níveis de operações, em um primeiro, externo, a roupagem econômica e em um segundo, interno, o negócio transferência de tecnologia (FUNKE, G. Technologietransfer in internationalen Corporate Joint Ventures: eine Untersuchung zu dem Wirtschaftsordnungsrecht im Hinblick auf patentrechtlich nicht geschützte Technologie, p. 16).
} 
Nosso objeto de análise excluirá, entre os contratos de transferência de tecnologia, os contratos que envolvam a transferência de informação sujeita a direito de propriedade industrial. Assim, entre os contratos listados no item (a) excluímos aqueles referentes à licença de tecnologias patenteadas e aquelas protegidas por meio de desenho industrial no território brasileiro.

Logo, refulgem como objeto crucial de análise as operações de transferência internacional de tecnologia para o Brasil, por meio de contratos de fornecimento de know$h o w^{18}$ e de prestação de serviços técnicos. A diferenciação entre as modalidades está na forma de comunicação dos conhecimentos: (i) diretamente pela entrega de documentos no fornecimento de know-how (manuais, desenhos, plantas, lay-out de maquinário e outros) ${ }^{19}$ ou (ii) indiretamente, por meio de técnicos que repassam o conhecimento, ao prestar serviços que são aproveitados pela parte adquirente ${ }^{20}$.

Essas categorias são aquelas que envolvem com maior intensidade a transmissão da técnica e geralmente estão presentes como negócio jurídico adicional e acessório em todas as modalidades indiretas de transferência anteriormente mencionadas.

Os serviços técnicos podem referir-se a uma fase pré-operacional - quando a linha de produção ou fábrica está sendo planejada - ou operacional - quando a produção já está em andamento. A diferenciação é relevante para fins de tratamento tributário e definição dos parâmetros de remuneração, como analisaremos no capítulo respectivo. Ainda dentro da categoria de serviços técnicos, distingue-se entre o gênero a assistência técnica pelo fato de que o método ou sistema é ensinado ao tomador dos serviços diretamente.

\footnotetext{
${ }^{18} \mathrm{O}$ próximo subitem, 3., analisará o conceito de know-how.

${ }^{19}$ Estes contratos são denominados contratos de "fornecimento de tecnologia industrial" pelo INPI - Instituto Nacional da Propriedade Industrial. Conforme a definição que consta do site do INPI: "Contratos que objetivam a aquisição de conhecimentos e de técnicas não amparados por direitos de propriedade industrial, destinados à produção de bens industriais e serviços. Esses contratos deverão conter uma indicação perfeita do produto, bem como o setor industrial em que será aplicada a tecnologia" (disponível em: <www.inpi.gov.br>, acesso em: 05/11/2009).

${ }^{20}$ Estes contratos são denominados pelo INPI de "contratos de prestação de serviços de assistência técnica e científica". Conforme a definição que consta do site do INPI: "Contratos que estipulam as condições de obtenção de técnicas, métodos de planejamento e programação, bem como pesquisas, estudos e projetos destinados à execução ou prestação de serviços especializados. São passíveis de registro no INPI os serviços relacionados à atividade fim da empresa, assim como os serviços prestados em equipamentos e/ou máquinas no exterior, quando acompanhados por técnico brasileiro e/ou gerarem qualquer tipo de documento, como por exemplo, relatório" (disponível em: <www.inpi.gov.br>, acesso em: 05/11/2009).
} 
Entendemos, ainda, que a prestação de serviços técnicos sempre envolverá transferência de tecnologia ${ }^{21}$. Pela própria natureza do conhecimento, mesmo que não exista sob o contrato autorização de uso do know-how utilizado na prestação, aprende a empresa receptora indiretamente o conhecimento, por meio do acompanhamento do trabalho do técnico ou do próprio contato com o resultado final. É verdade que esse aprendizado é mais intenso quando a prestação contratual é destinada especificamente ao aprendizado da técnica, como no caso dos contratos de assistência técnica. Porém, retirar do contrato de serviços técnicos a transferência de tecnologia, ainda que indireta, ${ }^{22}$ pelo acompanhamento do serviço, pela leitura de um relatório produzido ou, ainda, pela natureza mesma do conhecimento envolvido na prestação, não nos parece o caminho correto.

Vale ressaltar, entretanto, que não é qualquer prestação de serviços que envolve transferência de tecnologia. Sua prestação deve envolver ou implicar necessariamente uma informação caracterizável como tecnologia, conforme a definição construída no subitem 1 , imediatamente anterior ${ }^{23}$.

\section{Tecnologia, Know-how e Segredo de Negócio - A Proteção pelo Direito Brasileiro da Propriedade Industrial}

Conforme analisamos no Item 1, a doutrina nacional e internacional não demonstra uniformidade sobre os conceitos abrangidos no termo tecnologia. Os agentes econômicos utilizam comumente o termo "know-how" para designar a tecnologia não patenteada ou não sujeita ao direito de propriedade.

\footnotetext{
${ }^{21}$ Vale salientar que algumas modalidades de serviços técnicos tais como serviços arquitetônicos ou serviços de suporte de software, não são registráveis pelo INPI e, portanto, não serão abrangidas neste trabalho. Abordaremos esta situação no Capítulo II, Item 2.3, que trata da natureza da tecnologia sujeita à regulação do Instituto.

${ }^{22}$ Condição para tal é que o receptor tenha condições, i.e. esteja preparado tecnicamente, para aprender a técnica por meio da operação.

${ }^{23}$ Gabriel Leonardos adota posicionamento diferente, de que a prestação de serviços técnicos apenas implicará em transferência de tecnologia se houver, implícita ou explicitamente, a autorização de uso posterior do knowhow por aquele que tomou os serviços. O autor fundamenta com o fato de que esta diferenciação é inclusive utilizada no direito tributário internacional, daí os serviços técnicos nem sempre estarem incluídos no conceito de royalties dos Tratados Internacionais para Evitar a Bi-Tributação, nem no art. 12 da convenção-modelo da OCDE. LEONARDOS, G. A Tributação da Transferência de Tecnologia. Rio de Janeiro: Forense, 1997, p. 95 e 96.

Ressaltamos que é comum negociar-se a inclusão de serviços técnicos no conceito de royalties do tratado específico a ser assinado, por meio de seu Protocolo, conforme analisaremos a seguir, no capítulo referente à política tributária.
} 
Ocorre que o termo know-how também não foi definido legalmente, devendo seu conceito ser extraído do jogo interpretativo feito pelo jurista ${ }^{24}$. Sua origem é do círculo anglosaxão e deriva da prática, sendo abreviação da expressão "know how to do it", ou, "saber como fazer". Termo surgido da prática comercial, é consenso que know-how necessariamente deve ter aplicabilidade no comércio e na indústria. Encontra-se na doutrina posicionamento de que o know-how, para ser caracterizado como tal, deveria ser secreto ${ }^{25}$.

Discordamos deste ponto de vista, que surge da falta de delineamento dos termos e conceitos que vão sendo criados pela prática. Tecnologia, como analisamos no Item 1, constitui a totalidade dos conhecimentos utilizados para a produção e comércio de bens e serviços, desde que sistematizados. Know-how refere-se àquela parte da tecnologia que não está protegida por um direito de propriedade industrial em sentido estrito, tal como uma patente ou um desenho industrial. Já a questão da confidencialidade, refere-se à proteção da informação pela propriedade industrial de forma indireta, conforme veremos infra.

O know-how se perfaz de informação, bem imaterial, sendo perfeitamente possível sua transferência de forma plena a um terceiro. Essa transferência, porém, não implicará automaticamente a não-utilização pelo sujeito anterior. $\mathrm{O}$ sujeito que detinha a informação anteriormente não terá como apagá-la da memória, como esvaziar seu conhecimento daquela informação, daquele know-how. Será possível delimitar-se contratualmente a utilização pelo sujeito anterior. Ou, ainda, limitar esse uso pelo sujeito a práticas leais. Porém, não faz sentido limitar o uso de uma informação que muitos detêm, isto é, não faz sentido limitar o uso de uma informação de conhecimento público, que não esteja sujeita à proteção por meio de propriedade, como a patente, por exemplo ${ }^{26}$. Assim, o know-how adquire proteção limitada

\footnotetext{
${ }^{24}$ Conforme LARENZ, Karl. Metodologia da Ciência do Direito. 2. ed. Lisboa: Fundação Calouste Gulbekian, 1983 , p. 236 e ss.

${ }^{25}$ Conforme STUMPF, Herbert. Der Lizenzvertrag. 5. ed. Heidelberg: Recht und Wirtschaft, 1984, p. 18.

${ }^{26}$ Lei 9.279/96, art. 5’: "Consideram-se bens móveis, para os efeitos legais, os direitos de propriedade industrial." Newton Silveira elucida que a partir da percepção da humanidade de que a criação não se exauria somente em um exemplar, mas poderia ser reproduzida e multiplicada, formou-se a consciência de que ao criador pertencia sua obra, criação que não se confundia com a matéria. Tratava-se de uma classe de bens intangíveis ligados à pessoa do autor, assim como coisas materiais que lhe pertençam (SILVEIRA, N. A Propriedade Intelectual e as Novas Leis Autorais. São Paulo: Saraiva, 1998, p. 13 e ss.). A ideologia subjacente ao direito imaterial que se reconhecia teve, à época, três principais teorias; a de direito da personalidade; a de monopólio legal de direito privado, oriundo da tradição inglesa e consubstanciado no Statute of Monopolies de 1624 e a de propriedade, baseada na lei francesa de 1791 e no Patent Act dos Estados Unidos de 1790. O conceito que acabou por predominar foi o da propriedade, ainda que a propriedade sobre bens intangíveis guarde diferenças fundamentais em relação à propriedade de bens materiais.
} 
pelo direito brasileiro, com base na repressão à concorrência desleal, por meio de responsabilidade criminal e civil, mas desde que sejam informações sigilosas ${ }^{27}$.

Dentro do direito da propriedade intelectual, o vocabulário utilizado para designar dados técnicos e informações sobre como fazer é variado. A Lei 5.772/71 tratava separadamente de informações referentes à indústria e ao comércio, referindo-se a segredo de indústria e a segredo de comércio. Atualmente, ambos são tratados de forma homogênea pela Lei 9.279/96. Entendeu-se que ambos servem à atividade empresarial; a denominação amplamente aceita pela doutrina é "segredo de negócio". ${ }^{28}$

Assim, começamos no nível mais abrangente de tecnologia, descemos para o know-how, e, dentro do know-how, para o segredo de negócio.

Logo, recebe a proteção pelo instituto jurídico da concorrência desleal a informação utilizável na indústria, comércio ou prestação de serviço e que seja confidencial, ou não seja de conhecimento público, ou não seja evidente para um especialista técnico no assunto $^{29}$.

\footnotetext{
${ }^{27}$ Conforme Pontes de Miranda: "Não há prazo para a duração do direito sobre o segredo de fábrica ou de indústria; se o novum deixa de existir (outros já chegaram ao mesmo meio de fabricação ou de produção), ou se deixa de existir o segredo, - o direito extingue-se" (PONTES DE MIRANDA. Tratado de Direito Privado. Parte Especial. Campinas: Bookseller, 2002, Tomo XVI, p. 573).

${ }^{28}$ Conforme explicitado por Elisabeth Fekete, a doutrina entende cabível uma definição englobadora de todos os segredos que compõem a esfera privada da empresa, na categoria de segredos empresariais (FEKETE, E. K. $O$ Regime Jurídico do Segredo de Indústria e Comércio no Direito Brasileiro. Rio de Janeiro: Forense, 2003, p. 17 e ss.). Vide também Jacques Labrunie: "Nos dias atuais, a tendência é referir-se genericamente à tecnologia ou know-how, em sentido amplo, e referir-se a segredo de negócio também em sentido amplo, abrangendo qualquer tipo de know-how secreto, que os norte-americanos denominam de trade secret" (LABRUNIE, J. A Proteção ao Segredo de Negócio. In: SIMÃO FILHO, A.; LUCCA, N. (coord.) Direito Empresarial Contemporâneo. 2. ed. São Paulo: Juarez de Oliveira, 2004a, p. 92).

${ }^{29}$ Conforme a letra da Lei 9.279/96:

"Art. 195. Comete crime de concorrência desleal quem: (...)

XI - divulga, explora ou utiliza-se, sem autorização, de conhecimentos, informações ou dados confidenciais, utilizáveis na indústria, comércio ou prestação de serviços, excluídos aqueles que sejam de conhecimento público ou que sejam evidentes para um técnico no assunto, a que teve acesso mediante relação contratual ou empregatícia, mesmo após o término do contrato;

XII - divulga, explora ou utiliza-se, sem autorização, de conhecimentos ou informações a que se refere o inciso anterior, obtidos por meio ilícitos ou a que teve acesso mediante fraude;

(...)§ $1^{\circ}$ Inclui-se nas hipóteses a que se referem os incisos XI e XII o empregador, sócio ou administrador da empresa, que incorrer nas tipificações estabelecidas nos mencionados dispositivos.(...)

Art. 206. Na hipótese de serem reveladas, em juízo, para a defesa dos interesses de qualquer das partes, informações que se caracterizem como confidenciais, sejam segredo de indústria ou de comércio, deverá o juiz determinar que o processo prossiga em segredo de justiça, vedado o uso de tais informações também à outra parte para outras finalidades.

Art. 207. Independentemente da ação criminal, o prejudicado poderá intentar as Ações cíveis que considerar cabíveis na forma do Código de Processo Civil” (grifos nossos).
} 
Dessa última característica deriva o valor econômico da informação em questão, pois a informação que todos conhecem ou todos da área técnica conhecem não possui valor econômico em si mesma, na medida em que qualquer um pode utilizar-se da informação de conhecimento público. Não haveria uma vantagem competitiva ou de mercado ao utilizá-la.

Entendemos que, quanto maior a quantidade de pessoas que têm acesso ou conhecimento de uma determinada informação, menor o seu valor econômico. Ou seja, o valor econômico da informação é inversamente proporcional à quantidade de pessoas que a conhecem.

A fragilidade de proteção pela concorrência desleal reside na falta de um direito de uso exclusivo da informação oponível a quaisquer terceiros. Caindo em domínio público, o valor comercial da informação é perdido e seu antigo titular não tem qualquer direito de ação contra terceiros que passam a utilizá-la, mas somente contra aquele que violou a obrigação de sigilo. O desenvolvimento autônomo da mesma informação por um terceiro também é algo passível de ocorrer e, nessa situação, não haverá uma forma de defesa para o titular da informação, pois que o desenvolvimento foi independente, sem qualquer recurso aos e uso indevido dos dados do primeiro titular ${ }^{30}$.

Ainda assim, a proteção da informação como segredo de negócio pode ser uma escolha da parte que a desenvolveu. Mesmo quando a informação poderia ser suscetível de patenteamento, há situações em que se opta pela proteção sob outro sistema.

A um, porque o sistema de patentes é estruturado com base na publicidade. A patente é um direito concedido pelo governo de determinado território para premiar a atividade inventiva, mas exige como contrapartida que a invenção se torne pública para a

\footnotetext{
${ }^{30}$ Pontes de Miranda explica que o segredo de fábrica ou de indústria possui eficácia erga omnes, porém não real: "O sistema jurídico brasileiro absteve-se de considerar direito real o direito sobre o segredo de fábrica ou de indústria. É direito de eficácia perante todos, pois todos têm de admitir que exista e não seja violado, abstendose, portanto, de ofensas. Não se lhe atribuiu a realidade que se reconheceu à obra literária, científica ou artística, nem à patente de invenção e dos modelos de utilidade, nem ao registro dos desenhos industriais" (PONTES DE MIRANDA. Tratado de Direito Privado, p. 571). Labrunie também defende que no caso do segredo de negócio não existe uma abrangência de proteção erga omnes, pelo fato de não ser o direito de propriedade: “(...) Impossível obrigar, como regra, que toda a coletividade respeite os segredos de negócio de uma determinada empresa. (...) havendo contrato entre o titular do segredo e o usuário da informação, a questão será resolvida pelo princípio pacta sunt servanda. O titular do segredo estará protegido pela relação contratual.” Continuando mais adiante, o mesmo autor dispõe: “(...) o terceiro que teve acesso ao segredo por meios ilícitos ou mediante fraude também será claramente responsabilizado, criminal e civilmente. É fato que trata-se ainda de regra restrita. Repita-se, o segredo de negócio não tem proteção ampla, decorrente do direito de propriedade" (LABRUNIE, J. A Proteção ao Segredo de Negócio, p. 103 e 104).
} 
sociedade, inclusive para usos excluídos da proteção patentária ${ }^{31}$ e também para que, vencido o seu período de proteção, terceiros possam colocar no mercado produtos que incorporem aquela invenção.

A dois, porque é proteção por período de tempo determinado.

A três, porque para fazer valer estes direitos é preciso acionar o judiciário, o que implica custos, determinado prazo e alguma incerteza jurídica quanto ao deslinde da questão.

E a quatro, como o processo de patenteamento de uma invenção implica custos, é um procedimento efetuado antes mesmo de se ter a exata noção do sucesso comercial da invenção; deve ser realizado para cada um dos países dos quais se pretenda obter a proteção patentária, já que se trata de proteção territorial. Vale notar que, quando se patenteia uma determinada invenção em um país, ela se torna pública. Os bancos de patentes são abertos para acesso internacional, o que implica que outras empresas, em países em que a proteção patentária não foi buscada, possam utilizá-la livremente, sem ter violado um segredo comercial, já que a publicidade conferida à invenção foi autorizada pelo próprio titular ao submeter-se ao processo de obtenção do direito de patente ${ }^{32}$.

Elisabeth Fekete lembra mais uma distinção. Concedida a patente, há a obrigação do titular de utilizar essa tecnologia, sob pena de se ter o direito compulsoriamente licenciado ou extinto ${ }^{33}$. Ora, se o Estado permite o uso exclusivo de determinada invenção, retirando a possibilidade de utilização pelo restante da sociedade (salvo exceções ao direito de patente), é justo exigir que a invenção seja efetivamente explorada. Já o segredo de negócio poderá ou não ser utilizado comercialmente, sem que isso afete em absoluto sua proteção.

A conseqüência é que o patenteamento torna-se desinteressante para empresas que detenham uma tecnologia facilmente copiável, e para empresas que não disponham de recursos para investir em vários processos de patenteamento ao redor do mundo. Ou não se

\footnotetext{
${ }^{31}$ Lei 9.279/96, art. 43 - são exemplos de usos excluídos: atos praticados com finalidade experimental, relacionados a estudos ou pesquisas científicas ou tecnológicas; atos praticados em caráter privado e sem finalidade comercial, entre outros.

${ }^{32}$ Neste sentido, Flores, C. entende que o maior custo da patente não é o administrativo, mas o estratégico, pois que a empresa sinaliza para o mercado a tendência tecnológica e onde seus recursos financeiros estão sendo aplicados (FLORES, C. Segredo Industrial e o Know-how Aspectos Jurídicos Internacionais. Rio de Janeiro: Lumen Juris, 2008, p. 58).

${ }^{33}$ FEKETE, E. K. O Regime Jurídico do Segredo de Indústria e Comércio no Direito Brasileiro, p. 98. Lei 9.279/96, art. 68 - referente à licença compulsória e arts. 78, 80, 81, 82 e 83 quanto à extinção do direito pela caducidade.
} 
sintam confortáveis ou com estrutura para ter um processo de violação de patente em cada parte do mundo, ao qual tenham de recorrer, para proteger sua invenção. Conclui-se, assim, que o segredo de negócio não é necessariamente um sistema de proteção subsidiário ao sistema de patentes ${ }^{34}$, mas um sistema de proteção, com prós e contras, em relação ao sistema de proteção por patente.

A ressalva relevante a ser feita é que nem toda tecnologia tem de estar protegida pela propriedade intelectual ou industrial a fim de poder ser objeto de uma operação que tenha a transferência de tecnologia como seu objeto principal. Um contrato de transferência de tecnologia não precisa conter conhecimentos protegidos por propriedade intelectual, pois a caracterização de transferência de tecnologia e a caracterização da propriedade intelectual da informação nela contida são assuntos distintos.

A doutrina levanta a questão se haveria de se ter um valor econômico para que o know-how possa ser transferido onerosamente num contrato de transferência de tecnologia. Certamente uma informação disponível a muitos possui um valor econômico inferior, mas isso não significa que a parte receptora não tenha interesse em receber essa informação juntamente com explicações adicionais e assistência na maneira como ela deve ser empregada ou implementada ${ }^{35}$. A questão foge do âmbito e jurídico e passa ao âmbito econômico e político. E, como tal, será abordada ao analisarmos a atuação do INPI em relação a estes contratos, Capítulo II, Item 2.

\footnotetext{
${ }^{34}$ FLORES, C. Segredo Industrial e o Know-how Aspectos Jurídicos Internacionais, p. 58. Mais adiante em sua obra (p. 108), Cesar Flores cita, ainda, Guillermo Cabanellas, para quem a proteção de segredos industriais pode ser contraria à ordem pública, caso desestimule a apresentação de patentes como forma de proteção (Regimen jurídico de los conocimientos técnicos. Buenos Aires: Heliasta, 1984, p. 72).

${ }_{35}$ Altin-Sieber reconhece valor econômico ao know-how não secreto, por exemplo quando o receptor tem interesse em poupar tempo e custo de absorção e incorporação deste conhecimento, optando por adquiri-lo de quem já o incorporou, testou e o conhece (ALTIN-SIEBER, I. Joint Ventures, Technologietransfer und - schutz. Heidelberg: Recht und Wirtschaft, 1996, p. 47). Leonardos entende que "o contrato de know-how pode ter por objeto tecnologia sigilosa bem como a que esteja em domínio público. As obrigações das partes serão, naturalmente, distintas em um caso e em outro. Tais diferenças far-se-ão notar nos termos e condições contratuais, que, normalmente, serão tanto mais favoráveis ao recipiente da tecnologia quanto maior for o numero de fontes dessa tecnologia" (LEONARDOS, G. A Tributação da Transferência de Tecnologia, p. 95). Flores tem entendimento diverso: “(...) se a tecnologia estava em domínio público, na época da celebração do contrato, este será nulo, por falta de objeto" (FLORES, C. Segredo Industrial e o Know-how Aspectos Jurídicos Internacionais, p. 92).
} 


\section{Aspectos do Direito dos Contratos / Natureza Jurídica da Transferência de Tecnologia}

\subsection{Características Gerais do Contrato}

Os contratos de transferência de tecnologia são sinalagmáticos, comutativos e, usualmente, bilaterais, escritos e onerosos.

A operação de transferência de tecnologia comumente envolve duas partes, fornecedor e receptor da tecnologia. Mas a categoria de contrato admite também um plurilateralismo, tanto da parte fornecedora quanto da parte recipiente da tecnologia ${ }^{36}$. São também sinalagmáticos, pois com o consenso nascem obrigações para as partes contratantes e as obrigações nascidas para cada parte são causa uma da outra. Contrapostas e equivalentes, as obrigações de (i) disponibilizar as informações e prestar os serviços e (ii) a obrigação de pagamento e de confidencialidade ${ }^{37}$.

É comum haver contratos tácitos de transferência de tecnologia entre empresas coligadas, mas a legislação brasileira é clara ao exigir o registro do contrato de transferência de tecnologia no INPI para que produza efeitos em relação a terceiros ${ }^{38}$. Entendemos, contudo, que a forma escrita não é condição de validade do contrato, ainda que em alguns ordenamentos jurídicos a forma tenha sido considerada condição de validade para contratos com cláusulas que imponham validamente uma limitação à concorrência ${ }^{39}$.

\footnotetext{
${ }^{36}$ Para fins de registro no INPI, o multilateralismo certamente criará dificuldades. Não há procedimento previsto no INPI para um contrato multilateral com vários fornecedores, por exemplo. Do ponto de vista de remessa de pagamentos ao exterior, a pluralidade de fornecedores também não é abrangida pelo registro no Sistema Eletrônico do Banco Central do Brasil - Sisbacen.

${ }^{37}$ Sobre o sinalagma vide LABRUNIE, J. A Proteção ao Segredo de Negócio, p. 100.

${ }^{38}$ Art. 211 da Lei 9.279/96. Assim, havendo pagamentos, por exemplo, faz-se necessário que o contrato esteja registrado no INPI. O registro pelo INPI será analisado no Capítulo II.

${ }^{39}$ Caso da Alemanha, conforme o $§ 24$ da GWB, antes da sua adaptação ao direito comunitário europeu. Sobre o assunto vide: HENN, Günter. Patent und Know-how Lizenzvertrag. 3. ed. Heidelberg: Recht und Wirtschaft, 1992, p. 209, e MARTINEK, M. Moderne Vertragstypen, p. 256. João Marcelo Assafim entende que: "Embora a tese não tenha um amparo mais sólido na legislação brasileira, nos inclinamos a pensar que a ausência da exigência da forma escrita em contratos de transferência de tecnologia (...) produz, na prática, um nível tal de dificuldades que nos leva a entender que a ausência de instrumento escrito incide na própria validade do negócio jurídico (ASSAFIM, J. M. A Transferência de Tecnologia no Brasil Aspectos Contratuais e Concorrenciais da Propriedade Industrial. Rio de Janeiro: Lumen Juris, 2005, p. 144).
} 
Nada impede que a transferência de tecnologia seja gratuita. Usualmente esta pode se delinear gratuita quando a parte recipiente já adquire, por exemplo, maquinário ou equipamento do fornecedor da tecnologia. A gratuidade não necessariamente retirará o sinalagma do contrato, pois que poderá haver outras prestações da receptora satisfazendo os interesses da parte fornecedora. ${ }^{40}$

\subsection{Caracterização da Natureza Jurídica do Contrato: Prestação de Serviços, Licença ou Cessão}

Maior dificuldade existe quanto à caracterização da forma de circulação do conhecimento. Há uma transferência de tecnologia quando se concede a possibilidade de uso de uma tecnologia a terceiro, voluntariamente. Em se tratando da prestação contratual de assistência técnica ou de serviços técnicos, a concessão da possibilidade de uso ocorre indiretamente, já que a transferência de tecnologia não é o objeto principal da transação. Nesse caso, a natureza jurídica da prestação principal sob o contrato delineia-se como prestação de serviços, que não apresenta extensos desafios doutrinários ${ }^{41}$. Já quanto à prestação contratual de disponibilização direta de informações, que ocorre na transferência de know-how propriamente dita, analisaremos, a princípio, as figuras da licença e da cessão.

O instituto da licença não é usualmente definido nos ordenamentos jurídicos, nesse sentido, o ordenamento jurídico brasileiro não é exceção ${ }^{42}$. Trata-se de modo de circulação típico dos bens intangíveis, por meio do qual se autoriza o uso a terceiros, sem que a titularidade original do bem seja transferida ${ }^{43}$.

Independentemente de sua natureza jurídica específica e única, faremos o raciocínio de analogia da licença com o instituto da locação do nosso código civil para fins de

\footnotetext{
${ }^{40}$ Neste mesmo sentido, ASSAFIM, João Marcelo. A Transferência de Tecnologia no Brasil Aspectos Contratuais e Concorrenciais da Propriedade Industrial, p. 147.

${ }^{41}$ Analisando-se os artigos principais da prestação de serviços no código civil pátrio, cabe-nos reiterar que a limitação temporal de quatro anos para a prestação de serviços contida no art. 598 do Código não se aplica a esta modalidade de prestação de serviços. As partes poderão pactuar livremente sua duração, que a fim de ser aprovada pelo INPI deverá ser razoável conforme o objetivo subjacente da operação: conserto de maquinário, treinamento de mão-de-obra, etc.

${ }^{42}$ Para a Alemanha, vide: STUMPF, H. Der Lizenzvertrag, 1984, p. 55 e ss.

${ }^{43}$ Sobre a tipicidade, cumpre comentar que embora os contratos de transferência de tecnologia estejam expressamente previstos em lei (art. 211 da Lei 9.279/96), seu conteúdo e regras não são objeto de lei, somente de regulação administrativa. Assim, entendemos que uma tipicidade não pode ser derivada da singela menção em lei. Posição contrária adota ASSAFIM, João Marcelo. A Transferência de Tecnologia no Brasil Aspectos Contratuais e Concorrenciais da Propriedade Industrial, p. 153.
} 
embasamento da análise. A associação da locação com a licença é, de início, quase que imediata. Conforme o artigo 565 do Código Civil em vigor:

Na locação de coisas, uma das partes se obriga a ceder à outra, por tempo determinado ou não, o uso e gozo de coisa não fungível, mediante certa retribuição.

As regras e a doutrina sobre a locação de coisas são utilizadas de modo subsidiário para as licenças de direitos imateriais, guardadas as devidas diferenciações do fato de seu objeto tratar de bens intangíveis. Já para informações não sujeitas ao direito de propriedade, a subsidiariedade muitas vezes resta prejudicada, conforme analisaremos a seguir. $^{44}$

Temos como elementos característicos da definição legal de locação a (i) cessão ${ }^{45}$ a um terceiro do (ii) uso e gozo de (iii) coisa não fungível (iv) mediante certa retribuição (v) por tempo determinado ou não.

O primeiro e segundo requisitos da licença seriam a cessão do uso e gozo a terceiro. Não se pode licenciar validamente mais do que se tenha direito. Assim, se não se tem o controle sobre o uso e gozo de uma informação, não se pode ceder isso a terceiro. No caso específico do segredo de negócio, como analisamos anteriormente, não há um direito de propriedade da informação. A proteção à informação por meio do instituto da concorrência desleal não confere ao titular nem mesmo direito de uso exclusivo da informação, pois que ela poderá ser desenvolvida e usada autonomamente por terceiro. Porém, a propriedade ou o direito de uso exclusivo não estão entre os requisitos legais para que se configure a licença. Não é necessário ser o proprietário da coisa para ter o controle sobre seu uso e gozo. Se eu detenho, tenho acesso àquela informação, sem com isso estar infringindo um direito de terceiro ou uma relação contratual, eu posso licenciá-la validamente. Inclusive, assim como na locação se admite a operação de sublocação, na licença se admite a operação de sublicença. A sublocação tem a mesma natureza jurídica da locação. A sublicença teria a mesma natureza jurídica da licença.

\footnotetext{
${ }^{44}$ A caracterização da transferência de know-how como licença é polêmica. Para tanto, vide BARTENBACH, K., GENNEN, K.; GAUL, D. Patentlizenz- und Know-how-Vertrag. 4. Aufl. Koeln: O. Schmidt, 1997, p. 25 e ss; FUNKE, G. Technologietransfer in internationalen Corporate Joint Ventures: eine Untersuchung zu dem Wirtschaftsordnungsrecht im Hinblick auf patentrechtlich nicht geschützte Technologie, p. 37 e ss.; Der Lizenzvertrag. 5. ed. Heidelberg: Recht und Wirtschaft, 1984, p. 55 e ss.

${ }^{45}$ Utilizaremos nos parágrafos seguintes o verbo ceder no sentido de disponibilizar, somente com a intenção de replicar o vocabulário do art. 565 do Código Civil referente à locação. Para bens imateriais o termo cessão possui um significado diferente e específico, como veremos ainda neste item, contrapondo-o à licença.
} 
O terceiro requisito diz respeito ao objeto, de ser coisa não fungível. A informação, da qual a tecnologia se constitui, é certamente coisa não fungível quando sujeita a proteção como segredo de negócio, ou seja, quando confidencial. Uma informação não confidencial geralmente possuirá uma diferenciação muito tênue das demais informações disponíveis, sua infungibilidade restará prejudicada. Nesse caso, torna-se necessário analisar se a informação está sistematizada, constituindo uma tecnologia em si mesma. Havendo uma sistematização, ela começa a se diferenciar. A vantagem competitiva em receber onerosamente a informação pode estar na velocidade com que será possível aplicar a tecnologia na situação concreta, pois a informação será recebida sistematizada. Isso porque, mesmo sendo uma informação disponível, interessa a um terceiro especificamente aquela tecnologia com aquele conhecimento de aplicação, com aquela experiência prática; assim ela se torna diferençável das demais. A própria sistematização ou a maneira de transmissão e ensino da informação podem ser confidenciais, ou de acesso restrito.

Concluímos que algum conteúdo da informação deve ser de acesso restrito e de conhecimento não público, caso contrário não se consegue fazer a diferenciação entre a transferência integral da informação e sua licença. Em se tratando de bem intangível, que pode ser utilizado concomitantemente por uma miríade de sujeitos, não há como evitar a transferência total da informação. Uma vez fornecida, não há como voltar atrás. $\mathrm{O}$ conhecimento se aprende, talvez se esqueça, mas o esquecimento não é algo voluntário.

A diferenciação entre transferir de vez a informação ou apenas ceder o seu uso e gozo (temporário ou não) ocorrerá por meio do delineamento contratual da transação. Exemplos disso são cláusulas de devolução dos documentos e materiais, restrição ao uso das informações após o término contratual, confidencialidade. Na licença de segredo de negócio tem-se somente o componente negativo, qual seja, do licenciador eximir-se de utilizar sua faculdade de se insurgir contra o licenciado. ${ }^{46}$

Neste ponto encontramos dificuldade em reconhecer a possibilidade de existência da licença de informação de domínio público. Se ela já é de domínio público, como restringir seu uso após o término do contrato, exigir confidencialidade ou devolução de documentos que

\footnotetext{
${ }^{46}$ Ahrens, 2008, p. 20 e ss e 162 e ss. Conforme UNCTAD: "O know-how é explorado por meio da transferência contratual protegida e restrita. $\mathrm{O}$ contrato poderá conter cláusulas que protejam o know-how contra o abuso pela parte recipiente por meio da ferramenta de cláusulas restritivas que controlem a liberdade do recipiente de ação ao aplicar o know-how". UNCTAD - United Nations Conference on Trade and Development. Transfer of Technology. United Nations Publication. New York and Geneva, 2001. Disponível em: <http://www.unctad.org/en/docs//psiteiitd28.en.pdf>. Acesso em: 20/01/2010, p. 89 (nossa versão do inglês).
} 
já estão na posse de uma diversidade de terceiros? Que efeito surtirá, exigir-se isso de um só agente detentor da informação entre tantos? Concluímos, portanto, que para ser objeto de licença parte da informação deve necessariamente ser de acesso restrito. Acesso restrito deve ser entendido nesta hipótese em sentido abrangente, acesso restrito em determinado território geográfico, em determinada área de atuação. Trata-se de um conceito diferente do conceito de novidade utilizado como requisito essencial para a patenteabilidade de uma invenção ${ }^{47}$.

Quanto ao requisito da onerosidade, não o entendemos como tipificador da licença. Licenças gratuitas são comuns, a contraprestação pelo fornecimento de informação pode se revestir de outras prestações, que não afetam em absoluto o sinalagma do contrato.

Já a temporalidade do contrato de licença de know-how é um aspecto controverso. Se concluído sem limitação de prazo, aproxima-se de uma compra de tecnologia, já que não haveria praticamente como se diferenciar as duas operações. Realmente, o fornecimento de informações não pode ser revertido. Porém, sendo o know-how secreto, da sua manutenção como tal deriva parte substancial de seu valor comercial. Assim, no contrato incluir-se-ão cláusulas respectivas de devolução da informação com o término ou rescisão do contrato, de manutenção de confidencialidade, restringindo mesmo o uso da tecnologia.

Concluímos, assim, que o contrato de licença de know-how não possui uma natureza jurídica específica. Em se tratando de operação sui generis, pode adquirir a natureza de uma locação, de uma compra, de um arrendamento, de uma sociedade. Conforme o caso concreto, é possível trazer à aplicação subsidiária normas de diferentes institutos jurídicos. Logo, o que determinará se, na prática, ocorre ou não uma "licença" do segredo de negócio/informação são as condições pactuadas para o negócio.

A cessão, para os direitos de propriedade intelectual, é entendida como a operação pela qual se transfere a propriedade do direito - seja uma marca, uma patente, um desenho industrial, uma cultivar - de uma pessoa física ou jurídica a outra. Na cessão, o antigo proprietário deixa de ter qualquer espécie de disponibilidade sobre aquela informação da qual

\footnotetext{
47 Alexandre Gnocchi tem posicionamento ligeiramente divergente: "Pergunta-se se "dados de natureza confidencial" podem ser objeto de um contrato de licença. Respondemos sim e não. (...) o requisito da novidade é elemento fundamental para a validade de um contrato dessa natureza. Não se justificaria, e constituiria modalidade de fraude, uma licença formada sobre "dados de natureza confidencial" já em domínio público" (GNOCCHI, A. Licenças e Roialties no Brasil. São Paulo: Revista dos Tribunais, 1960, p. 206).

Para uma análise do conceito de novidade em patentes vide LABRUNIE, J. Direito de Patentes - Condições Legais de Obtenção e Nulidades. Barueri: Manole, 2006, p. 60 e ss.
} 
o direito é constituído ${ }^{48}$. Mesmo em se tratando de informação - a qual todos poderiam utilizar concomitantemente - com base na mesma ficção jurídica que instaurou a propriedade sobre aquele direito de propriedade intelectual, podemos apreender o sentido da transferência de propriedade desse mesmo direito a um terceiro, extinguindo todos os direitos de uso e gozo que o antigo proprietário possuía, a partir da data da cessão. Daí a analogia comum com o instrumento da compra e venda do art. 481 do Código Civil:

Pelo contrato de compra e venda, um dos contratantes se obriga a transferir o domínio de certa coisa, e o outro, a pagar-lhe certo preço em dinheiro.

Com a diferenciação premente de que a onerosidade, elemento definidor da compra e venda, inexiste na cessão, a cessão gratuita é perfeitamente possível e corriqueira.

Para a hipótese da informação que não é objeto de um direito de propriedade intelectual, chegamos, novamente, à conclusão de que o delineamento da transação é que definirá a operação como cessão. A primeira dificuldade que se apresenta é a de como limitar os direitos de uso e gozo do know-how ao detentor original da informação, já que a informação se difundiu com o aprendizado e não há direito de uso exclusivo por determinado agente. Aqui, como na licença, chega-se à solução pelas regras contratuais delineadas para a transação. Instransponível, porém, a dificuldade de se admitir a cessão de uma informação que é de domínio público. Não há cessão de informação de domínio público.

A problemática da definição da natureza jurídica da operação num contrato de transferência de tecnologia está no fato de que, ao registrar estes contratos, o INPI modifica as cláusulas contratuais pactuadas pelas partes. Assim, acaba por transformar uma licença de know-how, usualmente contratada, em operação ainda diferente da cessão, pois que ao final do contrato o fornecedor permanece utilizando-se das informações. Assim, quando da atuação do INPI em relação a estes contratos, realmente lidando com conceito sui generis. Cabanellas, ao discorrer sobre a atuação das autoridades de registro de transferência de tecnologia na América Latina dispõe que, “em certos casos, não é possível aplicar as disposições da

\footnotetext{
${ }^{48}$ Alexandre Gnocchi estabelece que: "A cessão é uma alienação. A licença é a autorização de uso ou exploração" (GNOCCHI, A. Licenças e Roialties no Brasil, p. 7).

João Marcelo Assafim discorre: "Assim, cabe estabelecer uma referência inicial com relação à extensão dos negócios jurídicos relativos à conclusão de um contrato pelo qual se transmitem bens imateriais juridicamente protegidos em duas situações distintas: aquela em que a titularidade do bem é transmitida sem limites; e aquela em que o bem contemplado no objeto do contrato de transmissão de tecnologia é transmitido de forma limitada. Na primeira situação, a relação jurídica se instrumenta mediante a cessão (assignment) e, na segunda, mediante a licença (license)" (ASSAFIM, J. M. A Transferência de Tecnologia no Brasil Aspectos Contratuais e Concorrenciais da Propriedade Industrial, p. 127).
} 
regulação sobre atos de transferência de tecnologia sem que se altere em certa extensão alguns princípios da lei de contratos". 49

\section{Conflito Tecnológico Norte-Sul}

Vivemos numa era de transição da economia de base industrial para uma economia de bens imateriais como recursos estratégicos. Na sociedade da informação, há a procura por informação adaptada às diferentes necessidades de utilizadores privados e públicos, o que tem estimulado a criação de uma vasta gama de produtos e serviços da informação ${ }^{50}$.

A transferência de tecnologia se intensifica, fomentando e estimulando a inovação. O progresso tecnológico e a capacidade de produção de um país são instrumentos valiosos para o seu progresso e desenvolvimento.

Por uma perspectiva econômica, a tecnologia agrega valor a bens e serviços, tornando-os mais competitivos em relação a outros. Além disso, padrões tecnológicos vão sendo estabelecidos, em alguns setores em velocidade recorde, tornando necessário aos produtores acompanhar esse desenvolvimento, sob o risco de não ter seus bens e serviços comercializados no mercado ${ }^{51}$.

As empresas têm dificuldade em alcançar o estado da técnica, uma sinergia de cooperação para desenvolvimento e aquisição de tecnologia confere uma vantagem

\footnotetext{
${ }^{49}$ CABANELLAS, G. J. Antitrust and direct regulation of international transfer of technology transactions: a comparison and evaluation. Weinheim; Deerfield Beach, Florida; Basel, Verlag Chemie, 1984, p. 26.

${ }^{50}$ Conforme Manuel Castells: "Uma nova economia surgiu em escala global no último quartel do século XX. Chamo-a de informacional, global e em rede para identificar suas características fundamentais e diferenciadas e enfatizar sua interligação. É informacional porque a produtividade e a competitividade de unidades ou agentes nessa economia (sejam empresas, regiões ou nações) dependem basicamente de sua capacidade de gerar, processar e aplicar de forma eficiente a informação baseada em conhecimentos. É global porque as principais atividades produtivas, o consumo e a circulação, assim como seus componentes (capital, trabalho, matéria-prima, administração, informação, tecnologia e mercados) estão organizados em escala global, diretamente ou mediante uma rede de conexões entre agentes econômicos. É rede porque, nas novas condições históricas, a produtividade é gerada, e a concorrência é feita em uma rede global de interação entre redes empresariais. Essa nova economia surgiu no último quartel do século XX porque a revolução da tecnologia da informação forneceu a base imaterial indispensável para a sua criação" (CASTELLS, M. A Sociedade em Rede - A Era da Informação: Economia, Sociedade e Cultura Volume 1. 11. ed. São Paulo: Paz e Terra, 2008, p. 119 e ss.).

${ }^{51}$ Como exemplo pode-se citar o setor de computadores, onde velocidades e capacidades de armazenamento são rapidamente atualizadas, tornando produtos antigos rapidamente obsoletos.
} 
competitiva temporal. Empresários utilizam-se de tecnologia alheia para evitar os custos de pesquisa e desenvolvimento. O licenciamento de know-how próprio também cumpre a finalidade de diminuir os custos internos de pesquisa e desenvolvimento, ou a tecnologia desenvolvida não serve a nenhuma finalidade onde foi gerada, e de tornar a própria tecnologia um standard da indústria, de cujo uso muitos dependerão.

O fato é que ainda se pode afirmar que (i) a maioria dos desenvolvimentos tecnológicos está concentrada em poucos países desenvolvidos e (ii) por conta dos direitos de propriedade intelectual tem-se um mercado tecnológico muito desenvolvido e uma dependência tecnológica mútua entre as empresas bastante elevada.

Comparato entende que "a grande 'trouvaille' do empresário capitalista foi, sem dúvida, perceber, muito cedo, que sua principal arma para a conquista dos mercados e do próprio poder político eram a apropriação e o desenvolvimento incessante da tecnologia $[\ldots]^{, 52}$.

No mesmo sentido, Ascensão afirma que tudo no desenvolvimento tecnológico aponta para a globalização, que "resulta da evolução tecnológica e de outras circunstâncias históricas, que levam a que se prefigure a circunstância em que o homem vai seguidamente viver". Mas a globalização não é so um facto: é também uma política. A maneira como a globalização se faz não está desligada da opção humana [...].",53

O desenvolvimento da economia mundial nas últimas décadas faz com que os países desenvolvidos percam competitividade para a fabricação de produtos em seu território, bem como para a produção de produtos agrícolas, de forma que se apegam ao monopólio das tecnologias que detêm e desenvolvem, a fim de obter vantagens competitivas.

Como parte da globalização, os detentores de tecnologia desejam uma proteção cada vez mais harmonizada e intensa dos direitos de propriedade intelectual, que lhe permitirão lucros maiores. Os países em desenvolvimento desejam mitigar essa proteção em prol do desenvolvimento de suas economias e de um aumento do bem-estar social de sua população.

\footnotetext{
${ }^{52}$ COMPARATO, F. Ética, p. 342 e ss.

${ }^{53}$ ASCENSÃO, J. O. Direito de Autor e Desenvolvimento Tecnológico: Controvérsias e Estratégias. Revista Forense, Rio de Janeiro, 2005 (374), p. 156.
} 
A Conferência das Nações Unidas Sobre o Comércio e Desenvolvimento UNCTAD - publicou em 2007 relatório sobre conhecimento e tecnologia aplicados a países menos desenvolvidos. A conclusão é de que conhecimento e aprendizado tecnológico são condições essenciais para o desenvolvimento desses países, principalmente o licenciamento de tecnologias estrangeiras, ainda que envolva custos de aquisição e riscos de absorção ${ }^{54}$.

Ocorre uma mudança significativa na atualidade, no sentido de que a moeda de troca para o fornecimento de tecnologia torna-se a liberalização do comércio. Retiram-se as discussões sobre propriedade intelectual do âmbito da OMPI (Organização Mundial da Propriedade Industrial) e elas são inseridas no âmbito do GATT (Acordo Geral sobre Tarifas e Comércio, da OMC - Organização Mundial do Comércio), por meio do TRIPS (Acordo Sobre Aspectos dos Direitos de Propriedade Intelectual Relacionados ao Comércio). Dentro dessa lógica, o descumprimento da proteção à propriedade intelectual acarreta sanções comerciais internacionais; ou o descumprimento de outros pontos do acordo pode levar a sanções na proteção da propriedade intelectual localmente ${ }^{55}$. Analisando-se a história das políticas industrial, comercial e tecnológica dos países desenvolvidos, temos um quadro bem diferente daquele exortado por comentaristas neoliberais e incentivado nos países em desenvolvimento $^{56}$. Parece-nos que a regulação é necessária, não há como deixar a absorção

\footnotetext{
${ }^{54}$ Sumário do relatório pode ser acessado em: <http://www.unctad.org > UNCTAD - United Nations Conference on Trade and Development. The Least Developed Countries Report 2007Knowledge, Technological Learning and Innovation for Development. United Nations Publication. New York and Geneva, 2007. Versão compilada disponível em: $<$ http//:www.unctad.org $>$.

${ }^{55}$ Vide MP 482 de 10/02/2010 e Resolução 15 de 05/03/2010 do Conselho de Ministros da Câmara de Comércio Exterior.

${ }^{56}$ A análise histórica de Karl Polanyi sobre a auto-regulação imperfeita do mercado nos anos 1879 a 1929 provoca-nos uma impressão de dejà-vu quanto à atual realidade: “(...) os métodos políticos eram usados para suplementar a auto-regulação imperfeita do mercado. A teoria ricardiana do comércio e meio circulante ignorou em vão a diferença de status existente entre os vários países, segundo a sua diferente capacidade de produzir riquezas, capacidade de exportação, de comércio, de navegação e de experiência bancária. Pela teoria liberal, a Grã-Bretanha era apenas mais um átomo no universo do comércio e ocupava precisamente o mesmo lugar que a Dinamarca e a Guatemala. (...) Tais diferenças podiam ser ignoradas pela teoria, mas suas conseqüências não podiam ser abandonadas da mesma forma na prática. Era freqüente os países ultramarinos estarem impossibilitados de atender às suas dívidas externas ou verem suas moedas depreciadas, o que ameaçava sua insolvência. Às vezes eles decidiam corrigir a balança através de meios políticos e interferiam na propriedade de investidores estrangeiros. Em nenhum desses casos se poderia depender dos processos econômicos autocurativos (...). Isto exigiria que os países envolvidos fossem participantes mais ou menos igualitários num sistema de divisão internacional do trabalho, o que não era o caso, enfaticamente.

Seria ocioso esperar que, por um processo invariável, o país cuja moeda se desvalorizasse aumentaria automaticamente suas exportações, restaurando assim o seu balanço de pagamentos, ou que sua necessidade de capital estrangeiro pudesse compeli-lo a compensar o estrangeiro e reassumir o montante da dívida. (...) $\mathrm{O}$ mecanismo do mercado mundial não podia se permitir correr tais riscos. Assim, enviavam-se navios de guerra para o local e o governo negligente, fraudulento ou não, se defrontava com a alternativa de um bombardeio ou um ajuste. Não havia outro método capaz de obrigar o pagamento, impedir grandes perdas e manter o sistema em funcionamento. Prática semelhante era utilizada para induzir os povos coloniais a receberem as vantagens do comércio, quando o argumento teoricamente infalível da vantagem mútua não era prontamente reconhecido
} 
da tecnologia pela mão-de-obra local dependente apenas de questões comerciais. As questões comerciais podem e devem focar a promoção da transferência de tecnologia internacional, mas elas jamais conseguirão dar conta da questão da absorção da tecnologia pela mão-de-obra local. Seu foco é outro ${ }^{57}$.

\section{A Tutela da Transferência de Tecnologia e da Proteção ao Segredo de Negócio no Direito Internacional}

Desde os anos 1960 os países em desenvolvimento têm expressado em vários fóruns internacionais o desejo de maior acesso a tecnologias estrangeiras e melhorias de sua capacitação tecnológica. O desenvolvimento cooperativo baseado em um tratamento diferenciado para os países não desenvolvidos em termos de propriedade intelectual, a "Nova Ordem Econômica Internacional" ${ }^{58}$, era idéia que teve início com a I Conferência das Nações Unidas para o Comércio e Desenvolvimento (UNCTAD) e o Grupo dos 77 (setenta e sete) países em desenvolvimento, instaurado ao final da Conferência. ${ }^{59}$

pelos nativos - e talvez jamais o fosse. (...) É claro que nenhuma dessas dificuldades deveria surgir sob um sistema supostamente auto-regulável. Todavia, enquanto cada vez mais os pagamentos só eram feitos sob a ameaça da intervenção armada, e as rotas comerciais se mantinham abertas apenas com a ajuda dos navios de guerra (...) mais patente se tornava o fato de que era preciso utilizar instrumentos políticos para manter o equilíbrio da economia mundial" (POLANYI, K. A Grande Transformação - As Origens de Nossa Época. Rio de Janeiro: Elsevier, 2000, p. 243 e ss.).

${ }^{57}$ CHANG, H. Chutando a Escada - A Estratégia do Desenvolvimento em Perspectiva Histórica. São Paulo: Ed. Unesp, 2003, p. 106.

Conforme matéria de capa da revista The Economist (Nov. 7th-13th, 2009) "So much gained, so much to lose", sobre os 20 anos da queda do muro de Berlim: “(...)Above all politics remains stubbornly local. All that economic integration has not been matched politically. And to the extent that there is a global guarantor of the current system, it is America, a country which as globalisation works will continue to lose relative Power. Thanks to its generosity in exporting the secrets of success, it now has China closer to its shoulder and other emerging giants are catching up. Public support for protectionism has surged in the United States (...)" (grifos nossos).

${ }^{58}$ Resolução 3202 (S-VI) da Assembléia Geral das Nações Unidas.

${ }^{59}$ Conforme consta em <http://www.unctad.org>: "Estabelecida em 1964, a UNCTAD promove a integração favorável ao desenvolvimento dos países em desenvolvimento na economia mundial. A UNCTAD progressivamente evoluiu para instituição reconhecida como autoridade por basear-se em conhecimento cujo trabalho pretende auxiliar no delineamento dos debates sobre políticas atuais para o desenvolvimento, com um foco particular em assegurar que políticas domésticas e ação internacional dão sustento uma à outra ao lograr o desenvolvimento sustentável.”. Último acesso em 03/01/09. Vide comentários de Barbosa, D. B. Uma Introdução à Propriedade Intelectual. 2. ed. Rio de Janeiro: Lumen Juris, 2003, p. 152. Silveira, N. comenta sobre o grupo dos 77, instituído no mesmo ano, que possui como um dos intuitos lograr um tratamento mais justo no comércio de tecnologia (SILVEIRA, N. Licença de Exploração de Patentes com Cláusula Acessória de Assistência Técnica - Royalties Contratados em Fraude à Lei. Revista de Direito Mercantil, n. 63 julho/setembro 1986(63), p. 97). 
Nas últimas duas décadas, cláusulas específicas sobre transferência de tecnologia foram incorporadas em diversos instrumentos internacionais. Essas provisões dispõem sobre diferentes objetivos, escopos e maneiras de implementação da transferência de tecnologia. $\mathrm{Na}$ grande maioria dos casos, entretanto, as cláusulas consubstanciam comprometimentos de “melhores esforços", somente.

No plano de ação de Bangcoc da $\operatorname{UNCTAD}^{60}$, a Conferência foi exortada a analisar os aspectos de transferência de tecnologia nos acordos internacionais. Essa ação gerou o "Compêndio de Acordos Internacionais sobre Transferência de Tecnologia: Instrumentos Selecionados" de $2001^{61}$.

O Compêndio lista 80 documentos contendo disposições sobre transferência de tecnologia e distingue duas principais formas de tratamento da transferência de tecnologia: (i) cláusulas que dispõem sobre o balanceamento dos interesses entre os criadores e os potenciais utilizadores da tecnologia - disponibilidade, escopo e uso dos direitos de propriedade intelectual e (ii) cláusulas que focam diretamente a transferência de tecnologia e promoção de capacidades, especificamente em países menos desenvolvidos. Nesta última hipótese, as cláusulas lidam com a tecnologia em setores específicos, tais como proteção do meio ambiente. $^{62}$

Geralmente, os instrumentos distinguem entre duas principais categorias de países destinatários das disposições, países desenvolvidos e em desenvolvimento, com o objetivo de destiná-los diferentes tipos de obrigações. Assim, as disposições sobre transferência de tecnologia referem-se especificamente a países em desenvolvimento, com baixa capacidade tecnológica. O Compêndio conclui que, apesar de a transferência de tecnologia ser um objetivo fundamental de muitos instrumentos internacionais, sua implementação e execução na prática ainda é um desafio.

\footnotetext{
${ }^{60}$ Plano de Ação de Bangcoc, parágrafos 117 e 128. UNCTAD - United Nations Conference on Trade and Development. Set of Multilaterally Agreed Equitable Principles and Rules for the Control of Restrictive Business Practices. United Nations Publication. New York and Geneva, 2000. Disponível em: $<$ http://www.unctad.org/en/docs/tdrbpconf10r2.en.pdf>. Acesso em: 19/02/2010.

${ }^{61}$ Compendium of International Arrangements on Transfer of Technology: Selected Instruments - relevant provisions in selected international arrangements pertaining to transfer of technology. (UNCTAD/ITE/IPC/Misc.5). Disponível em: <http://www.unctad.org/en/docs//psiteipcm5.en.pdf>.

${ }^{62}$ A adoção de compromissos de transferência de tecnologias harmônicas ao meio-ambiente tem sido uma preocupação recente e corriqueira dos instrumentos internacionais recentes. Vide: UNCTAD - United Nations Conference on Trade and Development. Transfer of Technology. United Nations Publication. New York and Geneva, 2001. Disponível em: <http://www.unctad.org/en/docs//psiteiitd28.en.pdf>. Acesso em: 20/01/2010, p. 21.
} 
A legislação brasileira na área de propriedade industrial foi paulatinamente adaptada nas últimas décadas aos padrões mínimos negociados internacionalmente no âmbito das convenções internacionais, caminhando para uma proteção cada vez mais acentuada e rigorosa dos direitos e aumentando as áreas de "uso exclusivo".

Analisaremos a seguir os instrumentos internacionais que consideramos mais relevantes para o presente trabalho. ${ }^{63}$

\subsection{A Convenção da União de Paris - CUP}

A Convenção da União de Paris para a Proteção da Propriedade Industrial foi acordada pela primeira vez em 1883. Desde então, foi revista sete vezes. No Brasil, vigora a versão de Estocolmo de $1967^{64}$. A cada nova revisão, a proteção aos direitos de propriedade industrial nos países-membros foi sendo harmonizada e intensificada ${ }^{65}{ }_{-}^{66}$.

Na CUP cada país possui liberdade para legislar em matéria de propriedade intelectual, obedecendo certos parâmetros mínimos indicados (bastante inferiores aos padrões TRIPS, que é posterior à CUP) e desde que conceda ao estrangeiro o mesmo tratamento que concede ao nacional. Não há na CUP uma regulamentação específica em termos de transferência de tecnologia ou know-how ou mesmo quanto ao segredo de negócio. Esses

\footnotetext{
${ }^{63}$ Para um estudo aprofundado das convenções internacionais na área de propriedade intelectual e sua evolução, sugerimos a consulta à tese de livre docência na Faculdade de Direito da Universidade de São Paulo no ano de 2000: "A Proteção Internacional dos Direitos de Propriedade Intelectual - Das Uniões Internacionais à OMCTRIPS.” Basso, M. O Compêndio da UNCTAD citado anteriormente compila todas as cláusulas de transferência de tecnologia dos 80 instrumentos que lista.

${ }^{64}$ Decreto 75.572/75. Decreto Legislativo 78/74. O Decreto 635/92 promulgou a revisão de Estocolmo. O Decreto $1.263 / 94$ ratificou a declaração de adesão aos arts. $1^{\circ}$ a 12 e ao art. 28 alínea 1 do texto da revisão de Estocolmo.

${ }^{65}$ A CUP e a Convenção de Berna para a Proteção de Obras Literárias e Artísticas de 1886 previam a criação de um escritório internacional. Os dois escritórios, das duas convenções, foram unificados em 1893. Em 1973, o BIRPI então criado, Bureaux Internationaux Réunis pour la Protection de la Propriété Intellectuelle, foi substituído pela Organização Mundial da Propriedade Intelectual (OMPI/WIPO), com a assinatura da Convenção da OMPI, em Estocolmo, em 1967, em força desde 1970 e alterada em 1979. Em 1974 a OMPI adquiriu o status de agência especializada do sistema da Organização das Nações Unidas.

${ }^{66}$ Denis Borges Barbosa lembra que a CUP surgiu originalmente da necessidade gerada pelo intercâmbio comercial entre as nações de economia de mercado do hemisfério norte (BARBOSA, D. B. Uma Introdução à Propriedade Intelectual, p. 157).
} 
termos não são sequer mencionados em referida Convenção. A proteção da concorrência desleal consta do art. 10 bis $^{67}$.

A última revisão da CUP, de 1980, não logrou sucesso. Os países em desenvolvimento pretendiam conseguir um equilíbrio maior entre os direitos dos titulares dos direitos de propriedade intelectual e os países em desenvolvimento, diminuindo os poderes daqueles e melhorando a criação e transferência de tecnologia para estes.

Os países desenvolvidos, em especial os Estados Unidos, não aceitaram a nova proposição em relação à revisão da CUP. Explicam que a propriedade industrial trata de interesses empresariais e não estatais, os quais se poderia transigir muito dificilmente ${ }^{68}$. Interessante a maneira como os Estados Unidos colocaram seu posicionamento, já que a proteção à propriedade industrial tem, sim, embasamento econômico, mas é inexoravelmente, uma opção política do Estado.

Na mesma época, mais especificamente em 1974, a UNCTAD negociava um Código de Conduta para a Transferência de Tecnologia.

\footnotetext{
${ }^{67}$ Art. 10 bis:"1) Os países da União obrigam-se a assegurar aos nacionais dos países da União proteção efetiva contra a concorrência desleal.

2) Constitui ato de concorrência desleal qualquer ato de concorrência contrário aos usos honestos em matéria industrial ou comercial.

3) Deverão proibir-se particularmente:

$1^{\circ}$ todos os atos suscetíveis de, por qualquer meio, estabelecer confusão com estabelecimento, os produtos ou a atividade industrial ou comercial de um concorrente;

$2^{\circ}$ as falsas alegações no exercício do comércio, suscetíveis de desacreditar o estabelecimento, os produtos ou a atividade industrial ou comercial de um concorrente;

$3^{\circ}$ as indicações ou alegações cuja utilização no exercício do comércio seja suscetível de induzir o público em erro sobre a natureza, modo de fabricação, características, possibilidades de utilização ou quantidade de mercadorias.".

${ }^{68}$ Denis Borges Barbosa relata sobre a reunião dos países da União para a revisão da Convenção: “(...) Coube ao representante americano, muito sério, nervoso no isolamento de um plenário de 120 países em que o único voto discordante era o seu, explicar a realidade das coisas: é sempre possível fazer concessões ao Terceiro Mundo, alimentar o ideal de uma nova ordem econômica mundial, da redistribuição dos papéis econômicos, quando se fala em termos de interesse público dos Estados. Mas na Convenção de Paris, o interesse direto em jogo é o das empresas, não dos Estados; e não se pode transigir o interesse das empresas tão facilmente.(...)" (grifos nossos) (BARBOSA, D. B. Uma Introdução à Propriedade Intelectual, p. 157), relatando o Documento WIPO PR/SM/3 (1983) Parágrafo 244.

Para uma leitura do contexto histórico, vide CHANG, H. Chutando a Escada - A Estratégia do Desenvolvimento em Perspectiva Histórica, p. 148.
} 


\title{
6.2. O Código Internacional de Conduta em Transferência de Tecnologia - TOT Code ${ }^{69}$
}

\author{
A Conferência das Nações Unidas sobre um Código de Conduta em Transferência
} de Tecnologia nasceu em 1974, como iniciativa que reconhecia o papel fundamental que a ciência e a tecnologia desempenham no desenvolvimento socioeconômico de todos os países e, em especial, na aceleração do desenvolvimento dos países menos desenvolvidos ou em desenvolvimento. ${ }^{70}$ Os grupos de negociação do TOT Code dividiram-se basicamente entre o Grupo dos 77 (países em desenvolvimento, incluindo o Brasil), o Grupo B (países desenvolvidos), o Grupo D (países socialistas e a Mongólia) e a China Popular como um quarto "grupo negociador". ${ }^{71}$ Há uma influência recíproca entre os assuntos negociados no âmbito do TOT Code e as legislações latino-americanas de transferência de tecnologia que foram promulgadas à época. ${ }^{72}$

Inicialmente, o Grupo dos 77 pretendia que o TOT Code tivesse natureza obrigatória, enquanto o Grupo B insistia para que a natureza jurídica adotada fosse a de conjunto de pautas de observância voluntária. Acabou por prosperar nas negociações a posição de que o TOT Code não teria força vinculante, mas tornar-se-ia um norte para as operações de transferência de tecnologia a serem contratadas internacionalmente. Como diretriz ou "soft law", qualquer ação estatal em conformidade com suas disposições estaria legitimada, mas nenhuma parte estaria estritamente obrigada a cumprir com o instrumento ${ }^{73}$.

${ }^{69}$ O texto atualizado do código, versão de 1985, está acessível no seguinte endereço eletrônico: $<$ http://stdev.unctad.org/compendium/themes/coc.htm>- último acesso em 07/05/2009.

${ }^{70}$ A Resolução 3202 (S-VI) da Assembléia Geral das Nações Unidas contém a Declaração Referente ao Estabelecimento uma Nova Ordem Econômica Internacional, sob a qual todos os esforços deveriam ser envidados a fim de se formular um Código Internacional de Conduta em Transferência de Tecnologia.

${ }^{71}$ CORREA, C. M. El derecho latinoamericano y la propuesta de regulación internacional de la transferência de tecnología: un análisis preliminar. 1981. Disponível em: $<$ http://www.iadb.org/intal/intalcdi/integracion_latinoamericana/documentos/057-

Derecho_de_la_Integracion_Estudios.pdf >,p. 32 .

${ }^{72}$ CORREA, C. M. El derecho latinoamericano y la propuesta de regulación internacional de la transferência de tecnología: un análisis preliminar. 1981. Disponível em: $<\mathrm{http}: / /$ www.iadb.org/intal/intalcdi/integracion_latinoamericana/documentos/057-

Derecho_de_la_Integracion_Estudios.pdf >, p. 33. Vide Capítulo II, Item 1.

${ }_{73}$ Apesar da sua natureza não vinculante, o instrumento foi igualmente difícil de se negociar, como se vinculante fosse. Acordos de observância voluntária são capazes de criar precedentes internacionais. O termo "soft law" é definido como "Expressão inglesa empregada (...) por aqueles que pretendem designar regras cujo valor normativo é limitado, pois que os instrumentos em que estão inseridas não são juridicamente obrigatórios (...). Considerada como um processo de finalidade normativa, uma regra de "soft law"será, entretanto - conforme os defensores desta expressão - suscetível de [i]gerar uma acumulação convergente de pretensões normativas [ii] acabar por constituir uma norma nova, com um caráter juridicamente obrigatório. De uma forma geral, o conceito é invocado quando de resoluções ou recomendações adotadas por diversas organizações internacionais (...). O conceito é, assim, invocado como uma manifestação contemporânea da opinio juris sive necessitatis. Acompanhado de uma prática adequada, pode ser criador de diversos costumes novos, os quais, apesar de serem 
A negociação do TOT Code estendeu-se até 1995, quando se encerrou por falta de consenso. $\mathrm{Na}$ tentativa de acordo os países participantes acabaram se dividindo em dois grupos principais e com interesses antagônicos: os países mais desenvolvidos (Grupo B) e os menos desenvolvidos (Grupo dos 77). Conforme comunicação do secretário geral da UNCTAD: ${ }^{74}$

\begin{abstract}
Não existem condições, atualmente, para se atingir um acordo integral sobre todas as questões ainda em aberto na minuta do código de conduta. Caso os Governos assim indiquem - diretamente ou por meio do Secretário-Geral da UNCTAD que reportará conforme a Resolução da Assembléia Geral 46/214 - que há a convergência de posições necessária para se alcançar um acordo em todas as questões pendentes, então a Comissão retomará e continuará os trabalhos, no intuito de facilitar o acordo sobre o Código (nossa versão do inglês).
\end{abstract}

Apesar do fracasso das negociações, é importante frisar que o preâmbulo do TOT Code contém considerações interessantes sobre o papel da tecnologia para o desenvolvimento: trata da necessidade de os países mais desenvolvidos darem acesso à tecnologia aos países menos desenvolvidos, considerando que todas as pessoas têm o direito de se beneficiarem dos avanços e desenvolvimentos em ciência e tecnologia a fim de melhorar seu padrão de vida.

Indo além do preâmbulo, pode-se dizer que o TOT Code contém diversos capítulos, estendendo-se desde definições sobre o que é transferência de tecnologia e até questões como objetivos e princípios, tratamento da matéria em território nacional por cada país, itens financeiros, exemplos de cláusulas restritivas, treinamento de mão de obra local, práticas para a negociação de contratos entre particulares. ${ }^{75}$

Havia efetivamente nos anos 60 e 70 interesse em regular-se a transferência internacional de tecnologia por meio de um código em que os países desenvolvidos e detentores de tecnologia colaborariam com o desenvolvimento das outras economias dos países em menor estágio de absorção tecnológica.

gerais, refletem a grande maioria que o subscreve (...)" (nossa versão do francês) (Dictionnaire de Droit International Public, Emile Bruylant, Bruxelas, 2001).

${ }^{74} \mathrm{TD} / \mathrm{CODE}$ TOT/60 Disponível em: <www.stdev.unctad.org/compendium/themes/coc.htm>. Acesso em: 07/05/2009.

${ }^{75}$ Capítulos: 1) Definições e Campo de Aplicação; 2) Objetivos e Princípios; 3) Regulação Nacional das Transações de Transferência de Tecnologia; 4) Regulação das Práticas Comerciais Restritivas; 5) Garantias, Responsabilidades, Obrigações; 6) Tratamento Especial para Países em Desenvolvimento; 7) Colaboração Internacional; 8) Máquina Institucional Internacional; 9) Lei Aplicável e Solução de Controvérsias. 
Entretanto, ao longo da década de 80, assistimos um desenvolvimento diferente no posicionamento desses países, que se intensifica na década de 90 .

\author{
O relatório mencionado dispõe: ${ }^{76}$
}

[...] A Comissão de Comércio e Desenvolvimento estabelecida no grupo de trabalho Ad Hoc sobre a Inter-relação entre Investimento e Transferência de Tecnologia relatou que (...) os países em desenvolvimento têm adotado como foco principal a formulação de políticas e instrumentos legislativos para a promoção e encorajamento de investimento estrangeiro e a transferência de tecnologia relacionada. Muitos países em desenvolvimento liberalizaram seu regime de investimento e tecnologia de transferência de tecnologia a fim de atrair mais investimento estrangeiro. A principal iniciativa adotada por estes países em prol da transferência de tecnologia tem sido a de focar na colaboração efetiva entre os parceiros envolvidos nas transações de transferência, mais do que no controle dos aspectos contratuais das transações. Mais recentemente, um número significativo de países também modificaram sua legislação de propriedade intelectual para fortalecer a proteção dos direitos de propriedade intelectual ou para introduzir novas medidas de proteção e defesa (grifamos).

Criticamos a posição exibida nesse relatório que exorta a mercantilização do direito e desvia o foco de atenção da política que se pretendia implementar em prol da prevalência do particular sobre as instituições. Procurar-se-ia criar, por meio dele, ordenamentos jurídicos que interessassem aos investidores, mas se deveria ter em mente que os interesses dos investidores nem sempre representam a melhor escolha de direito para a sociedade: diversas medidas podem ser tomadas a fim de incentivar o investimento estrangeiro, não representando um ou outro ponto da regulação, desfavorável aos interesses das corporações estrangeiras, um real impasse à transferência de tecnologia. ${ }^{77}$ É preciso

${ }^{76}$ TD/CODE TOT/60 Disponível em: <www.stdev.unctad.org/compendium/themes/coc.htm>. Acesso em: 07/05/2009.

${ }^{77}$ Sabino Cassese comenta a evolução da condição do ordenamento jurídico de cada país de um dado para uma eleição, onde o operador escolhe e expressa um juízo sobre a oferta do direito, como uma falência do Estado e a prevalência do particular sobre as instituições: "En primer lugar, se registra el pasaje de una estructura ordenada desde lo alto a un esquema de autoordenación. El ordenamiento jurídico, que era un dato, se transforma en una elección. De hecho, del lado de la "demanda del derecho", el operador puede realizar una elección, expresando así un juicio sobre la "oferta del derecho" y "adquiriendo" el más conveniente. (...) La elección es admitida para la búsqueda de la mejor tutela o del derecho menos severo o de aquél más conveniente. Los derechos o las administraciones objeto de la elección son, entonces, puestos en competencia. La replica de mercado que así se produce no es completa. Los derechos o los administraciones derrotadas, en realidad, no fallan. Sin embargo, aquellos vencedores amplían su esfera de dominio, yendo más allá de los confines nacionales, en un proceso acumulativo típico de la empresa que adquiere una posición dominante. Habría que preguntarse si el cuasimercado que así se desarrolla tiene necesariamente por efecto la optimización del resultado. (...) no se puede excluir que, en otros casos, la búsqueda del derecho menos severo y de la mejor tutela pueda resolverse en la prevalencia del peor derecho. Se ilustra así un paradigma, el de la "mercantilización" de las instituiciones que desmiente el paradigma tradicional por el cual las instituciones se imponen a los particulares, constituyendo un prerrequisito al cual estos últimos deben necesariamente adaptarse" (CASSESE, S. La Crisis Del Estado. Buenos Aires: Abeledo-Perrot, 2003, p. 152 e ss.). 
resgatar a legitimação do argumento do social neste campo do direito. ${ }^{78}$

\subsection{O TRIPS - Acordo Sobre Aspectos dos Direitos de Propriedade Intelectual Relacionados ao Comércio}

Na esteira das negociações iniciadas após o final da segunda guerra mundial a fim de fomentar o comércio mundial, logrou-se em 1993, ao final de mais uma rodada de negociações do Acordo Geral sobre Tarifas e o Comércio (GATT) ${ }^{79}$ (rodada de negociações do Uruguai), a criação de uma organização internacional - a Organização Mundial do Comércio (OMC) - bem como a execução de acordos-pilastras dessa organização: entre estes, o Acordo sobre Aspectos Comerciais dos Direitos de Propriedade Intelectual Relacionados ao Comércio (TRIPS). ${ }^{80}$

Ao estabelecer parâmetros de proteção mínima para os direitos de propriedade intelectual nos ordenamentos jurídicos dos países signatários, o TRIPS logrou aumentar a capacidade de efetivar e fazer valer os direitos de propriedade intelectual no mundo inteiro. ${ }^{81}$

Drahos e Braithwaite analisam a questão da negociação internacional na esfera da OMC e do TRIPS e como a dinâmica informal do poder desenhou-se a fim de criar o TRIPS com as cláusulas, expressões e palavras que contém. Concluem que se trata de produto das

\footnotetext{
${ }^{78}$ Neste sentido, DREXL, J. The Critical Role of Competition Law in Preserving Public Goods in Conflict with Intellectual Property Rights In: MASKUS, K.; REICHMAN, J. International Public Goods and Transfer of Technology under a Globalized Regime. Cambridge: Cambridge University Press, 2005, p. 715: “(...) não é importante somente que os fornecedores mais eficientes produzam os bens necessários. Também devemos considerar os ganhos oriundos da eficiência distributiva e como a habilidade de competir estará distribuída mundialmente entre os países e seus cidadãos. A análise empreendida até o momento clama a favor da reestruturação dos sistemas de propriedade intelectual, especialmente o sistema TRIPS, a partir de uma perspectiva social e global. Este objetivo torna-se particularmente difícil porque finalidades sociais, i.e. justiça distributiva, estão além do que a teoria econômica neoclássica pode explicar e descrever. Esta dificuldade, entretanto, não diminui a legitimidade do argumento social no direito. Neste sentido, os argumentos econômicos devem ser balanceados contra os argumentos sociais" (nossa versão do inglês).

${ }^{79}$ General Agreement on Tariffs and Trade.

${ }^{80}$ Vide HERDEGEN, M. Internationales Wirtschaftsrecht. 2. ed. Munique: Verlag C H Beck, 1995, p. 107 e ss. A ata final que incorpora os resultados da Rodado do Uruguai de Negociações Comerciais Multilaterais do GATT, que inclui o TRIPS, foi incorporada ao ordenamento jurídico brasileiro através do Decreto 1.355 de 30 de dezembro de 1994.

${ }^{81}$ Por exemplo, com a adesão ao TRIPS e a promulgação da Lei da Propriedade Industrial (Lei 9.279/96) tem-se a permissão de patenteamento de tecnologias em áreas anteriormente excluídas. A partir de então, existe a possibilidade de patenteamento, em território brasileiro, de tecnologias da área química, abrangendo mormente patentes na área de fármacos e alimentos. Inseriu-se inclusive uma regra de proteção de transição para patentes já concedidas e ainda em vigor em outros países do mundo, o mecanismo denominado "pipeline".
} 
estratégias globais de número relativamente pequeno de empresas e organizações empresariais que perceberam o valor da propriedade intelectual antes de quaisquer outros. ${ }^{82}$ Realmente, quando percebemos que, em uma economia globalizada, esses padrões de proteção afetam mercadorias tão básicas como sementes, serviços e o fluxo de informações é que aferimos seu custo real aos cidadãos e aos negócios. ${ }^{83}$

Ainda que institua um padrão elevado de proteção a esses direitos, o TRIPS contém em seu texto exceções importantes envolvendo a transferência e absorção de tecnologia. A recomendação da UNCTAD é de tornar o TRIPS mais eficaz quanto à transferência de tecnologia, incluindo uma revisão sobre seu impacto na capacitação tecnológica. Sugere também a instituição de comitês de coordenação interministerial nacionais e regionais para ajustar os parâmetros do TRIPS às necessidades dos países de inovação local. ${ }^{84}$

Nas disposições pertinentes, que analisaremos a seguir, delineiam-se critérios de "interesse público", "saúde pública" e "emergência nacional”, mas também critérios como “criação de base tecnológica estável”, "desenvolvimento tecnológico", "transferência internacional de tecnologia" e "disseminação de tecnologia".

O preâmbulo do TRIPS determina:

[...] Reconhecendo os objetivos básicos de política pública dos sistemas nacionais para a proteção da propriedade intelectual, inclusive os objetivos de desenvolvimento e tecnologia;

Reconhecendo igualmente as necessidades especiais dos países de menor desenvolvimento relativo a Membros no que se refere à implementação interna de leis e regulamentos com a máxima flexibilidade, de forma a habilitá-los a criar uma base tecnológica sólida e viável; [...] (grifamos)

\footnotetext{
${ }^{82}$ DRAHOS, P.; BRAITHWAITE, J. Information Feudalism - Who Owns the Knowledge Economy? London: Earthscan Publications, 2002, Prefácio e p. 192. Vide também sobre o cenário de negociações e o posicionamento dos países de terceiro mundo: LANDES, W. M.; POSNER, R. A. The Economic Structure of Intellectual Property Law. Cambridge, Massachussets e Londres: The Belknap Press of Harvard University Press, 2003, p. 22.

${ }^{83}$ A propriedade intelectual foi vista na época da negociação do TRIPS e ainda é vista por alguns segmentos como uma questão de longo prazo e com efeitos incertos. A liberalização de barreiras para certos produtos certamente tem um apelo muito mais imediato e o apoio de extensos setores da economia dos países em desenvolvimento.

${ }^{84}$ Compendium of International Arrangements on Transfer of Technology: Selected Instruments - relevant provisions in selected international arrangements pertaining to transfer of technology, p. 305 e ss. (UNCTAD/ITE/IPC/Misc.5). Disponível em: <http://www.unctad.org/en/docs//psiteipcm5.en.pdf>.
} 
Mais adiante, encontramos referências mais específicas à questão da transferência de tecnologia propriamente dita. Assim, por exemplo, o artigo 7 referente aos Objetivos:

A proteção e a aplicação de normas de proteção dos direitos de propriedade intelectual devem contribuir para a promoção da inovação tecnológica e para a transferência de tecnologia, em benefício mútuo de produtores e usuários de conhecimento tecnológico e de uma forma conducente ao bem-estar social e econômico e a um equilíbrio entre direitos e obrigações. (grifamos)

Também o artigo seguinte, $8^{\circ}$, dos Princípios:

1- Os Membros, ao formular ou emendar suas leis e regulamentos, podem adotar medidas necessárias para proteger a saúde e nutrição públicas e para promover o interesse público em setores de importância vital para seu desenvolvimento sócioeconômico e tecnológico, desde que estas medidas sejam compatíveis com o disposto neste Acordo.

2- Desde que compatíveis com o disposto neste Acordo, poderão ser necessárias medidas apropriadas para evitar o abuso dos direitos de propriedade intelectual por seus titulares ou para evitar o recurso a práticas que limitem de maneira injustificável o comércio ou que afetem adversamente a transferência internacional de tecnologia ${ }^{85}$ (grifamos).

$\mathrm{O}$ art. $7^{\circ}$ deve ser interpretado em conjunto com o art. $8^{\circ}$. Uma interpretação ampla dos textos sugere que os países-membros possuem, por uma questão de princípio, discrição considerável para impor sua política de concorrência e medidas relacionadas à transferência de tecnologia, desde que o nível geral de proteção à propriedade intelectual internamente esteja em harmonia com o do TRIPS. Não obstante, não resta claro como a proteção dos direitos de propriedade intelectual poderá contribuir para a transferência de tecnologia nesses países. O relatório da UNCTAD sobre transferência de tecnologia indica que, "a menos que estas cláusulas sejam interpretadas como impondo algumas obrigações sobre os países exportadores de tecnologia, elas oferecerão pouco mais do que inspiração de esperanças para os países em desenvolvimento." 86

No artigo 40, inserido na Seção 8, de Controle de Práticas de Concorrência Desleal em Contratos de Licenças, observa-se:

1 - Os Membros concordam que algumas práticas ou condições de licenciamento relativas a direitos de propriedade intelectual que restringem a concorrência podem afetar adversamente o comércio e impedir a transferência e disseminação de tecnologia.

\footnotetext{
${ }^{85}$ TRIPS, Artigo 8, Princípios.

${ }^{86}$ UNCTAD - United Nations Conference on Trade and Development. Transfer of Technology. United Nations Publication. New York and Geneva, 2001. Disponível em: <http://www.unctad.org/en/docs//psiteiitd28.en.pdf>. Acesso em: 20/01/2010, p. 29 e 30 (nossa versão do inglês).
} 
2 - Nenhuma disposição deste Acordo impedirá que os Membros especifiquem em suas legislações condições ou práticas de licenciamento que possam, em determinados casos, constituir um abuso dos direitos de propriedade intelectual que tenha efeitos adversos sobre a concorrência no mercado relevante. Conforme estabelecido acima, um Membro pode adotar, de forma compatível com as outras disposições deste Acordo, medidas apropriadas para evitar ou controlar tais práticas, que podem incluir, por exemplo, condições de cessão exclusiva, condições que impeçam impugnações da validade e pacotes de licenças coercitivos, à luz das leis e regulamentos pertinentes desse Membro. [...] (grifamos)

O art. 66, de título: "Países de Menor Desenvolvimento Relativo Membros", contém, ainda, norma orientadora do estímulo da transferência de tecnologia para essas economias: ${ }^{87}$

Os países desenvolvidos Membros concederão incentivos a empresas e instituições de seus territórios com o objetivo de promover e estimular a transferência de tecnologia aos países de menor desenvolvimento relativo Membros, a fim de habilitá-los a estabelecer uma base tecnológica sólida e viável (grifamos)

A decisão do Conselho do TRIPS de fevereiro de 2003 (IP/C/28) ${ }^{88}$ estipula que os Países Desenvolvidos Membros deverão fornecer relatórios sobre a implementação do art. 66.2 nos países menos desenvolvidos em períodos trienais, a serem complementados anualmente e fornecidos ao Conselho do TRIPS. Também trienalmente, os critérios estabelecidos para os relatórios serão revistos em sua eficácia e efetividade e, eventualmente, alterados.

Em trabalho sobre o status do desenvolvimento na implementação do art. 66.2 do TRIPS, Moon ${ }^{89}$ mostra que não houve um incremento na transferência de tecnologia para países em desenvolvimento. A autora ressalta que há uma dificuldade em analisar e comparar os relatórios dos vários países, pois o termo "transferência de tecnologia" não foi definido; ademais, não há como verificar se algo além do usual no curso normal de negócios entre os países está sendo fornecido como resultado o art. 66.2 do TRIPS. Assim, conclui sugerindo a alteração do artigo do TRIPS, com intuito de tornar sua redação mais incisiva e clara.

Adicionalmente, pode-se dizer que, especificamente no tocante ao segredo de negócio e à concorrência desleal, o TRIPS não traz inovações ou novos padrões de proteção

\footnotetext{
${ }^{87}$ Apesar do Brasil não poder ser classificado como um País Menos Desenvolvido Membro, a discussão do artigo é interessante, a fim de traçar conclusões geras sobre o status dos direitos e obrigações sob o TRIPS.

${ }^{88}$ Disponível em: <http://www.wto.org/english/tratop_e/trips_e>. Acesso em: 22/11/2009.

89 "Does TRIPS Art. 66.2 Encourage Technology Transfer to LDCs? An Analysis of Country Submissions to the TRIPS Council (1999-2007)" ICTSD Project on IPRs and Sustainable Development - Policy brief Number 2. December 2008. Disponível em: <http://ictsd.net/downloads/2.008/12/policy_brief_2.pdf >. Acesso em $<22 / 11 / 2009>$.
} 
em relação aos que já existiam anteriormente no ordenamento jurídico brasileiro ou em outras convenções internacionais. O TRIPS, inclusive, refere-se à CUP para aplicação subsidiária do conceito de concorrência desleal para o seu artigo 39:

1 - Ao assegurar proteção efetiva contra competição desleal, como disposto no Artigo 10 "bis" da Convenção de Paris (1967), os Membros protegerão informação confidencial de acordo com o Parágrafo 2 abaixo, (...)

2 - Pessoas físicas e jurídicas terão a possibilidade de evitar que informação legalmente sob seu controle seja divulgada, adquirida ou usada por terceiros, sem seu consentimento, de maneira contrária a práticas comerciais honestas ${ }^{(10)}$, desde que tal informação:

a) seja secreta, no sentido de que não seja conhecida em geral nem facilmente acessível a pessoas de círculos que normalmente lidam com o tipo de informação em questão, seja como um todo, seja na configuração e montagem específicas de seus componentes;

b) tenha valor comercial por ser secreta; e

c) tenha sido objeto de precauções razoáveis, nas circunstâncias pela pessoa legalmente em controle da informação, para mantê-la secreta. (...)

(10): Para os fins da presente disposição, a expressão "de maneira contraria a práticas comerciais honestas" significará pelo menos práticas como violação ao contrato, abuso de confiança, indução à infração, e inclui a obtenção de informação confidencial por terceiros que tinham conhecimento, ou desconheciam por grave negligência, que a obtenção dessa informação envolvia tais práticas.

Conclui-se, então, que: (i) o termo "tecnologia" não foi definido no TRIPS, mas devemos interpretá-lo como tecnologia objeto de patente ou de outra regulação pertinente à propriedade intelectual, como o segredo de negócio; ${ }^{90}$ (ii) o acordo contém diversos dispositivos com exceções importantes à proteção da propriedade intelectual a serem utilizadas pelos países em desenvolvimento, tais como "criação de base tecnológica estável", "desenvolvimento tecnológico", "transferência internacional de tecnologia" e "disseminação de tecnologia".

Logo, nem mesmo o TRIPS, com seus padrões elevados de proteção à propriedade intelectual, logra impedir que o Brasil imponha regras e políticas específicas destinadas a incentivar a absorção de know-how pela mão-de-obra nacional: desde que se respeite em território nacional os direitos de patente, ${ }^{91}$ qualquer regulação de absorção de

\footnotetext{
${ }^{90}$ Assim, deve-se interpretá-lo a partir de seu significado comum, dentro do contexto do instrumento em que está inserido e à luz do objeto e objetivo do Tratado conforme o Art. 31.1 da Convenção de Viena sobre o Direito dos Tratados (promulgada pelo Decreto Presidencial 7.003/09 e aprovada pelo Decreto Legislativo 496/09). No caso do TRIPS, o objeto e objetivo do tratado é estabelecer padrões mínimos de proteção à propriedade intelectual, Assim, o termo "tecnologia" deve ser entendido como se referindo a tecnologia protegida por patentes ou outra forma de direito de propriedade intelectual.

${ }^{91}$ Vale ressaltar que o direito de patente é territorial, portanto, uma tecnologia patenteada em um determinado país, mas não no Brasil, não receberá qualquer proteção por propriedade intelectual em território nacional. Aliás, trata-se de tecnologia de conhecimento público, já que o patenteamento traz a público, mundialmente, a tecnologia, conforme analisamos no subitem 3 , acima.
} 
tecnologia protegida por segredo de negócio pela mão-de-obra local que se institua em território pátrio não representará violação aos termos do tratado, quanto mais aquela tecnologia não secreta, constituindo know-how, mas não segredo de negócio, conforme analisamos no subitem 3, supra. Isso reflete um posicionamento claro nas negociações: a tecnologia não patenteada tem relevância, cada país deseja adotar um regime diferente para sua regulação, a qual não foi objeto de negociação no âmbito do TRIPS.

Ullrich aponta que a reserva aos países-membros do estabelecimento de regras concorrenciais em acordos de licença é uma concessão efetuada em contrapartida ao esforço dos países em desenvolvimento em relação ao TOT Code, que não logrou ser assinado. ${ }^{92}$

Ponto crucial a ser considerado relativamente ao TRIPS é que a inclusão das exceções nele previstas foi negociada, isto é, implicou contrapartidas. As exceções devem ser utilizadas pelos países em desenvolvimento em sua máxima extensão, a fim de fazer valer o que se negociou dentro do pacote geral do TRIPS. ${ }^{93}$

Pode-se dizer que no período pós-TRIPS fortalece-se o mecanismo de negociação bilateral tendente a aumentar os níveis de proteção dos direitos; há um "novo bilateralismo" da propriedade intelectual, conforme expõe Basso. ${ }^{94}$ Recentemente, também em fóruns multilaterais, como, por exemplo, em acordos concluídos ou em negociação no âmbito da

\footnotetext{
${ }^{92}$ ULLRICH, H. Expansionist Intellectual Property Protection and Reductionist Competition Rules: a TRIPS Perspective. In: MASKUS, K.; REICHMAN, J. International Public Goods and Transfer of Technology under a Globalized Regime. Cambridge: Cambridge University Press, 2005, p. 730: "Esta reserva a favor da soberania da política de concorrência dos Membros representa concessão feita pelos países industrializados em resposta a um esforço anterior dos países em desenvolvimento de editar um Código de Conduta para a Transferência de Tecnologia" (nossa versão do inglês).

${ }^{93}$ Conforme Stiglitz, J. as regras do jogo da globalização foram desenhadas por certos interesses nos países avançados industrialmente e países como o Brasil devem tomar posição agressiva em defesa de um regime melhor balanceado. O que tomará tempo. Neste meio tempo têm de aprender a se virar da melhor maneira possível com as regras do jogo (STIGLITZ, J. Development Policies in a World of Globalization., p. 24).

94 “(...)Frente à realidade perversa de que para obter ajuda econômica os países em desenvolvimento devem prover seus ordenamentos internos com níveis maiores de proteção aos investidores estrangeiros, passaram a proliferar acordos de livre-comércio bilaterais e regionais (FTAs), assim como acordos bilaterais de investimentos (BITs) entre países desenvolvidos e em desenvolvimento. Tais acordos vêm disfarçados de certas benevolências porque, em tese, os países em desenvolvimento podem obter concessões adicionais e benefícios durante as negociações. Porém, na prática, revelam-se instrumentos coercitivos, politicamente desestabilizadores, inapropriados às necessidades de desenvolvimento sustentável e ao acesso à tecnologia e à saúde pública.

Enquanto o "antigo bilateralismo" não buscava necessariamente obter dos países em desenvolvimento substantivos compromissos de propriedade intelectual, o "novo bilateralismo" se utiliza de esquemas bilaterais e (até regionais) como instrumento para ultrapassar as limitações impostas pelo TRIPS e extinguir suas flexibilidades. Assim como, para expandir os direitos de propriedade intelectual em detrimento do interesse público tanto dos países em desenvolvimento quanto dos desenvolvidos. (...)" (grifos nossos). BASSO, M. Propriedade Intelectual na Era pós-OMC., Porto Alegre: Livraria do Advogado Editora, 2005, p. 11 e ss.
} 
OMPI, tem-se tentado - e logrado - aumentar o nível de proteção dos direitos de propriedade intelectual para além dos padrões atuais. ${ }^{95}$

\section{Necessidade do Foco da Regulação Nacional na Absorção de Tecnologia Localmente}

A política de intensificação da transferência de tecnologia por meio de mecanismos internacionais depende não somente de políticas regionais e internacionais, mas também de políticas nacionais. As intervenções devem ser parte do desenvolvimento de estratégias mais extensas, engendradas para o desenvolvimento de capacidades produtivas em todas as suas dimensões, incluindo o fortalecimento da capacidade de absorção doméstica de conhecimento.

Um componente-chave de qualquer processo de transferência de tecnologia é a efetiva transferência de habilidades e know-how intangível que assegurem a capacidade produtiva. Países receptores de tecnologia devem levar em consideração os seguintes pontos a fim de permitir e encorajar um ambiente de efetiva transferência de tecnologia: (i) recrutamento e treinamento de pessoal técnico; (ii) fomento das relações entre centros de pesquisa públicos e privados e empresas de consultoria; (iii) união de esforços e aproximação entre empresas e o Governo; (iv) encorajamento do desenvolvimento de capacitação para ter acesso, adotar, administrar e aplicar tecnologia por exemplo por meio do desenvolvimento de recursos humanos, fortalecimento de capacidade institucional de pesquisa e desenvolvimento, pesquisa e consulta sobre necessidades tecnológicas e parcerias de longo prazo entre detentores de tecnologia e receptores.

O licenciamento de tecnologias estrangeiras, ainda que envolva custos de aquisição e riscos de absorção, é imprescindível a fim de permitir o encalço do padrão tecnológico vigente nos outros países. Porém, a utilização da importação de tecnologia por

\footnotetext{
${ }^{95}$ Vide MASKUS, K. E.; Reichman, J. H. „The Globalization of Private Knowledge Goods and the Privatization of Global Public Goods, p. 6, sobre o "WIPO Copyright Treaty". "WIPO Performances and Phonograms Treaty" e negociações em curso na OMPI para a harmonização dos direitos de patente. Conforme RODRIK, D. Industrial Policy for the Twenty-First Century. September 2004. Disponível em: <http://www.ksg.harvard.edu/rodrik>. Acesso em: 18/08/2008, p. 35: "O Acordo TRIPS e suas versões bilaterais e regionais, ainda mais restritivas, tornam virtualmente impossível adotar-se uma estratégia de engenharia reversa e cópia. Os custos de desenvolvimento do TRIPS tiveram até o presente uma análise somente em relação à saúde pública e ao acesso a medicamentos. Seus efeitos adversos na capacidade tecnológica ainda devem receber a atenção devida" (grifamos e traduzimos do inglês).
} 
meio do licenciamento, como instrumento de acesso ao "pool" internacional de tecnologia, geralmente é considerado como diretamente relacionado ao nível de renda e sofisticação tecnológica das economias.

Isso porque, a fim de utilizar-se eficientemente deste canal de difusão tecnológica, é preciso que o país disponha de talentos na área de engenharia e programas de pesquisa e desenvolvimento para adaptação e ensino, em grau muito mais elevado do que em outros canais de importação de tecnologia (tais como o canal de compra de maquinário e equipamentos). $\mathrm{O}$ aprendizado associado a essa forma de transferência de tecnologia não ocorre automaticamente. Daí existir pouca atividade de licenciamento em países em estágios iniciais de alcance ao padrão tecnológico mundial. Esse canal é tipicamente utilizado e mais relevante em outros estágios, mais avançados, de desenvolvimento tecnológico. ${ }^{96}$

Como a intensificação de licenciamento de tecnologia não assegurará, por si só, que essas conexões internacionais trabalhem efetivamente como canais de difusão tecnológica, a intensidade do componente de aprendizado em cada transação deve ser valorizada. É preciso focar na intensidade do aprendizado e não no volume de contratos de licença. Somente assim ocorrerá a difusão tecnológica.

Pagamentos por meio de licenciamento estão geralmente associados à presença de corporações transnacionais no país. É natural que grande parte dos pagamentos em taxas de licenciamento ocorra entre empresas do mesmo grupo. Se este é o tipo de investimento estrangeiro direto ao qual o país estiver tendo acesso por parte da transnacional, então se deve estimular o licenciamento nesses países. Porém, deve haver uma política de ancoramento desta tecnologia nas economias domésticas dos países.

\footnotetext{
${ }^{96}$ UNCTAD - United Nations Conference on Trade and Development. The Least Developed Countries Report 2007 Knowledge, Technological Learning and Innovation for Development. United Nations Publication. New York and Geneva, 2007. Versão compilada disponível em: <http//:www.unctad.org>, p. 43. Generalizando, pode-se classificar os países em três categorias, conforme a sua relação com o conhecimento: os que produzem tecnologia, os que conseguem adaptar e copiar esta tecnologia e os que estão completamente excluídos da produção tecnológica, sendo simples consumidores, ou às vezes nem isso. Joseph Stiglitz afirma que "(...) o ingrediente central nas políticas de sucesso dos países do leste asiático foi a tentativa deliberada de fechar o abismo tecnológico. Estes países perceberam que o que os separava dos países mais desenvolvidos não era somente um abismo no capital, mas um abismo no conhecimento e eles trabalharam duro, e com sucesso, a fim de trazer a tecnologia moderna para suas sociedades. Hoje, em muitas áreas, eles estão ma linha de frente". (nossa versão do inglês) (STIGLITZ, J. Development Policies in a World of Globalization. Paper presented on the occasion of the fiftieth anniversary of the Brazilian Economic and Social Development Bank (BNDES). Rio de Janeiro, September 2002, p. 17).
} 
Políticas específicas para a difusão de tecnologia são necessárias. A questão que se impõe é: quais políticas específicas?

Nos países em desenvolvimento, a inovação é baseada principalmente em desenvolvimentos que fazem um acréscimo a tecnologias existentes, mais do que em contribuições originais para o estado atual do conhecimento. ${ }^{97}$ A informação não é só efeito do seu processo de produção, a informação é também condição de seu processo de produção. Assim, a sociedade seria beneficiada se os competidores tivessem a permissão de aperfeiçoar a inovação, após utilizá-la.

Estudo da UNCTAD demonstra que a aplicação de cláusulas de transferência de tecnologia em contatos de licenciamento é mecanismo recomendado fortemente para a governança de conhecimento ${ }^{98}$.

Dessa forma, entendemos que o Estado deve focar em políticas com medidas de prevenção a (i) práticas anticompetitivas pelos detentores dos direitos sobre a tecnologia ou (ii) práticas que impeçam "indevidamente" a transferência e disseminação de tecnologia. O conteúdo que se concederá ao "indevidamente" será definido pela política industrial e de inovação do país, tendo em vista seu interesse público. O controle dessas práticas é bastante comum em países desenvolvidos, mas é comum a falta de medidas legislativas nesta área nos países em desenvolvimento.

\subsection{Política Industrial}

\subsubsection{Considerações Teóricas}

Tradicionalmente, o Estado desempenha três funções básicas na economia, interferindo direta e indiretamente nos mercados. São elas: função estabilizadora (relacionada

\footnotetext{
${ }^{97}$ A inteiração com fornecedores, distribuidores e consumidores em um dado mercado gera a necessidade de aperfeiçoamentos na tecnologia para o local, que muitas vezes acaba por ser aproveitado mundialmente.

${ }^{98}$ UNCTAD - United Nations Conference on Trade and Development. The Least Developed Countries Report 2007 Knowledge, Technological Learning and Innovation for Development. United Nations Publication. New York and Geneva, 2007. Versão compilada disponível em: <http//:www.unctad.org>, p. XI.
} 
à política fiscal e monetária), função alocativa (relacionada à alocação de recursos para a provisão pública e privada de bens e serviços) e função distributiva (relacionada à aplicação dos parâmetros de igualdade socioeconômica desejados). ${ }^{99}$

A intervenção pública alocativa nos mercados se legitima a partir de falhas de coordenação, grandes efeitos para o mercado ou problemas significativos de apropriação, todos presentes numa economia do conhecimento baseada em inovação. ${ }^{100}$ Usando-se uma legitimação da política industrial sob a perspectiva desenvolvimentista, o Estado se legitimaria a exercê-la como uma função de transformação social e econômica, um elemento ativo e não somente focado na manutenção do sistema de mercado. Já sob a perspectiva de construção de competência para inovar, a política industrial assume um caráter microeconômico, privilegiando alguns setores em função da diferenciação de sua capacidade inovativa. Silva e Campanário definem política industrial da seguinte forma:

[...] a criação, a implementação, a coordenação e o controle estratégico de instrumentos destinados a ampliar a capacidade produtiva e comercial da indústria, a fim de garantir condições concorrenciais sustentáveis nos mercados interno e externo. ${ }^{101}$

O desenvolvimento de tecnologia e a promoção de inovações implicam custos altos, retornos incertos e uma fácil apropriação dos resultados. Assim, não são desdobramentos naturais de toda e qualquer empresa capitalista. Setores não-governamentais não estão preparados cientificamente para a pesquisa e também a pesquisa pública deve ser promovida, pois não subordinada aos interesses privados. ${ }^{102}$

\footnotetext{
${ }^{99}$ Para estudo sobre a relação das concepções de Estado com o embasamento das políticas públicas vide: CAMPANÁRIO, M. de A. Intenções Implícitas da Nova Política Industrial Brasileira. 2004. Material distribuído como leitura na disciplina "Política Industrial e Tecnológica", do Programa de Pós-Graduação da Faculdade de Economia e Administração da USP, em 2006, p. 3 e ss.

${ }^{100}$ Isto, sob uma perspectiva neoclássica. Vide STIGLITZ, J. Development Policies in a World of Globalization. Paper presented on the occasion of the fiftieth anniversary of the Brazilian Economic and Social Development Bank (BNDES). Rio de Janeiro, September 2002, p. 18.

${ }^{101}$ CAMPANÁRIO, M. de A.; SILVA, M. M. Fundamentos de Uma Nova Política Industrial. In: FLEURY, M.T.L.; FLEURY, A. Política Industrial 1. São Paulo: Publifolha, 2004, p. 13.

${ }_{102}$ Salomão Filho C. entende que os desafios do desenvolvimento econômico não serão devidamente considerados enquanto não se integrar melhor as questões de ciência e tecnologia nas estratégias básicas de desenvolvimento dos países de baixa renda. Caso contrário, a dependência tecnológica e econômica é reforçada em relação aos países desenvolvidos (SALOMÃO FILHO, C. Regulação e Desenvolvimento. São Paulo: Malheiros, 2002, p. 119 e ss.).
} 
Instrumentos de política de inovação são direitos de propriedade intelectual, ${ }^{103}$ financiamento público para pesquisa, descontos fiscais dados aos inovadores, encomendas públicas. Também a defesa da concorrência, que gera a necessidade de a empresa conquistar e manter seus mercados, pode ser considerada estímulo e parte da política de inovação.

A interferência do Governo nos mercados por meio da política industrial baseia-se em uma infra-estrutura institucional representada pelo aparato jurídico e regulatório governamental. Sua base, assim como seus limites, está na legislação de propriedade intelectual, de defesa da concorrência, tributária, cambial, entre outras, e em diretrizes constitucionais.

Focando especificamente a importação de tecnologia para difusão e promoção do encalço tecnológico, este item da política industrial deve fundamentar-se no direito de propriedade industrial e da concorrência, utilizando-se deles como instrumento de aplicação de seus objetivos.

\subsubsection{Histórico da Política Industrial Recente}

O processo de desenvolvimento industrial brasileiro norteou-se basicamente em (i) proteção ao mercado interno, (ii) políticas de comércio exterior, (iii) políticas de financiamento de bens de capital (base de toda a indústria de transformação) e (iv) industrialização acelerada em setores específicos com participação do Estado na economia por meio de empresas estatais, a chamada política industrial desenvolvimentista de substituição de importações, que se esgotou na década de oitenta (80).

A industrialização orientou-se no sentido de gerar capacidade produtiva com adoção de padrões tecnológicos relativamente atrasados e imposição de elevadas barreiras à entrada, impactando significativamente a capacidade do país de gerar, transferir e introduzir inovações tecnológicas.

\footnotetext{
103 A propriedade intelectual é instituída por lei, porém, o Estado possui espaço para ação em relação ao exercício dos direitos e às exceções abertas pela lei em relação ao interesse público, abuso de posição dominante, emergência nacional, entre outros.
} 
De grande relevância é o fato de a matriz tecnológica nacional não ter evoluído para setores mais dinâmicos da indústria, a exemplo do que ocorreu nos países asiáticos. Neles, políticas de apoio universal à inovação impactaram todas as cadeias produtivas e fazem avançar a microeletrônica, setor transversal no qual uma patente agrega valor à tecnologia de outras indústrias.

A abertura econômica ocorrida no Brasil nos anos 90 afetou drasticamente a indústria doméstica ${ }^{104}$, de forma que o Governo priorizou instrumentos da política de estabilização em detrimento da política industrial e tecnológica. Paradoxalmente, neste período a indústria sofre um processo de reestruturação, resultado da atração de investimentos diretos externos e maior penetração de importações sobre o processo de produção industrial local. Milton de Abreu Campanário aponta que com a introdução de insumos modernos ocorre uma especialização intra-indústria, promovendo economias de escala e especialização $^{105}$.

Com a estabilidade, a estratégia em torno da política industrial e tecnológica voltou ao foco central. Em 2004 o Governo Federal divulgou a PITCE (Política Industrial, Tecnológica e de Comércio Exterior), como parte do PPA 2004-2007 (Plano Plurianual), que delineia a diretriz estratégica do Governo Federal ${ }^{106}$. A PITCE foca em aumento da estrutura produtiva, capacidade de inovação e expansão das exportações como base para inserção do país no comércio internacional. O documento elege setores nos quais o Brasil tem maior capacidade ou necessidade: semicondutores, software, bens de capital e fármacos, num caráter seletivo, justificado pelo baixo desempenho desses setores nas exportações e sua contribuição para importações e, também, pela sua capacidade de difusão de progresso técnico. A PITCE articula-se por onze programas de política industrial e cinquienta e sete medidas.

\footnotetext{
${ }^{104}$ Conforme Campanário, M. A., Costa. T. R.; Muniz, M.M.: “A política econômica da era FHC promoveu a abertura econômica causando profundas mudanças estruturais na indústria ao afetar o nível de investimento, preços, quantum produzido, valor adicionado, margens, emprego, coeficientes de comércio e produtividade". CAMPANÁRIO, M. de A.; COSTA. T. R.; MUNIZ, M. M. Política Industrial, Tecnológica e de Comércio Exterior: Análise dos Fundamentos e Arranjos Institucionais. Palestra no IX Seminário Latino-Iberoamericano de Gestión Tecnológica - 25/28 Outubro de 2005, p. 1.

105 CAMPANÁRIO, M. de A. Intenções Implícitas da Nova Política Industrial Brasileira. 2004. Material distribuído como leitura na disciplina "Política Industrial e Tecnológica", do Programa de Pós-Graduação da Faculdade de Economia e Administração da USP, em 2006, p. 7 e ss.

${ }^{106}$ A PITCE se constitui de três (3) documentos: (i) Sexta Carta de Concertação: Política Industrial como Consenso Para uma Agenda de Desenvolvimento; (ii) Diretrizes de Política Industrial, Tecnológica e de Comércio Exterior e (iii) Medidas de Política Industrial e de Comércio Exterior - disponível em:

$<$ http://www.desenvolvimento.gov.br/sitio/inicial/index.php $>$.
} 
Dentre os programas, pode-se destacar na área tecnológica o sétimo, INO: Inovação de Produto, Processo e Gestão, com políticas que incentivem o processo de patenteamento e certificação, entre outras e o décimo primeiro, SINI: Fortalecimento do Sistema Nacional de Inovação, que foca a modernização e reestruturação dos institutos e centros de pesquisa e incentiva a parceria entre universidades, institutos de pesquisa e empresas ${ }^{107}$. No entanto, não há qualquer direcionamento específico para promover a importação de tecnologia estrangeira ${ }^{108}$.

Já com o novo PPA 2008-2011, a Política Industrial é renomeada para Política de Desenvolvimento produtivo - PDP, com maiores pretensões quanto à abrangência, profundidade, articulações, controles e metas. A elevação da capacidade de inovação das empresas brasileiras permanece como uma das prioridades. Um dos programas do PPA, o 0393, denomina-se "Desenvolvimento do Sistema de Propriedade Intelectual" e apresenta intenções de aperfeiçoar o marco regulatório de propriedade intelectual do país.

Focando na atuação do INPI, o Programa monitora as áreas de concessão de direitos de propriedade intelectual, entretanto não dispensa qualquer atenção à atividade de importação de tecnologia, regulada pelo INPI por meio do registro de contratos.

\subsection{Aplicação da Política Industrial de Absorção e Difusão de Tecnologia nos Contratos de Transferência de Tecnologia}

O Instituto Nacional da Propriedade Industrial, INPI, é a autarquia que atualmente tem a atribuição legal de registrar contratos que impliquem em transferência de tecnologia. Em relação a estes contratos, o INPI desenvolve há algumas décadas a atividade de regulamentação estatal da transferência de tecnologia para setores específicos da economia. A atuação do INPI deve ser pautada para regular o conteúdo dos contratos de transferência de tecnologia impedindo práticas anti-competitivas dos contratos e as que impeçam

\footnotetext{
${ }^{107}$ Com efeito, houve em 2004 a promulgação da Lei de Inovação, Lei 10.973/04 e em seguida da Lei do Bem, Lei 11.196/05. A partir destes diplomas legais, a política de incentivo à capacidade de criação tecnológica mudou de cenário e colocou a empresa no cerne do processo de inovação.

${ }^{108}$ Relatório do DIEESE - Departamento Intersindical de Estatística e Estudos Econômicos - aponta que a PITCE teve como legado a obtenção de marcos legais específicos [como a lei de inovação] e criação de linhas de crédito do BNDES para setores específicos, gerando frustração na indústria. (Nota Técnica 67 de maio de 2008).
} 
indevidamente a transferência e disseminação da tecnologia. Para tanto, deverá estar aparelhado com instrumento normativo adequado, inclusive com a utilização, dentro de sua área de competência administrativa e em coordenação com o órgão encarregado da defesa econômica, da política econômica antitruste instrumentada juridicamente pela lei de defesa da concorrência.

Defendemos, assim, a implementação de instrumento de política industrial que foque na criação de normas técnicas e legais que promovam a importação, transferência e consequiente difusão tecnológica, baseando-se em aspectos do direito da concorrência e do interesse público, conferindo competências específicas e claras ao INPI quando do registro dos contratos. 


\title{
CAPÍTULO II - FUNDAMENTOS JURÍDICOS E REGULATÓRIOS DA ATUAÇÃO DO INPI NO REGISTRO DOS CONTRATOS DE TRANSFERÊNCIA DE TECNOLOGIA
}

\begin{abstract}
Nós construímos explicações, em primeiro lugar, construindo uma estrutura política genérica. A estrutura política é a regra do jogo, definida por um governo; ela fornece regras econômicas e, especificamente, direitos de propriedade. Assim, se queremos entender direitos de propriedade e a forma como são exercidos, temos de entender a forma pela qual o sistema político criou e especificou a estrutura de direitos de propriedade como ela existe. [...] nossa forma [de construir explicações] é deficiente de um sistema de modelos que entenda o mundo dinâmico. [...] Um das questões cruciais sobre o mundo em que vivemos hoje, que certamente tornou-se óbvia com a atual crise financeira é que o mundo está evoluindo. O que fazia sentido e estruturava o jogo ontem não necessariamente funciona hoje e amanhã. E, então, estamos presos ao fato de que um sistema dinâmico significa que temos de entender não somente aonde estamos, mas aonde estamos indo. ${ }^{109}$
\end{abstract}

O Capítulo apresenta as linhas mestras da regulação das operações de transferência de tecnologia no país, envolvendo os seguintes vetores: (i) vetor de substituição de importações, (ii) vetor tributário, (iii) vetor cambial, (iv) vetor absorção e difusão de tecnologia, (v) vetor propriedade intelectual e (v) vetor concorrencial. Os três primeiros vetores foram os prevalecentes na aplicação e interpretação da regulação face às vicissitudes de um país de industrialização retardatária e periférico na economia global, que teve de priorizar a estabilização econômica ao invés do desenvolvimento tecnológico. Na atual conjuntura da economia mundial, a regulação da transferência de tecnologia deve ser retomada como instrumento de inserção e de permanência dos agentes econômicos locais no mercado global, competindo. A nova chave de aplicação e interpretação da regulação da transferência de tecnologia é a que prioriza os três últimos vetores: absorção e difusão de tecnologia e instrumentalização da concorrência pela propriedade intelectual.

\section{Contexto Histórico e Econômico da Regulação dos Contratos de Transferência de Tecnologia.}

\footnotetext{
${ }^{109}$ NORTH, D. C. A Recommendation on How to Intelligently Approach Emerging Problems in Intellectual Property Systems. Review of Law and Economics, vol. 5, iss. 3, Article 9, 2009. Disponível em: <http//www.bepress.com/rle/vol5/iss3/art9>. Acesso em: 05/01/2010, p. 1133. (nossa versão do inglês).
} 
O Brasil foi um país de industrialização retardatária. A partir dos anos $30^{110} \mathrm{e}$, sobretudo, depois da Segunda Guerra Mundial, teve um fabuloso crescimento econômico, e o setor industrial tornou-se um eixo para a economia. De fato, a fase desenvolvimentista pósguerra havia gerado uma enxurrada de políticas industriais protecionistas nas economias mundiais, com vistas a preservar uma indústria nascente da competição internacional.

A partir de 1945 e até o governo de João Goulart adotou-se políticas ativas de substituição de importações ${ }^{111}$. A década de 50, principalmente a segunda metade, foi marcada pelo avanço do processo de industrialização brasileiro. Houve vigoroso investimento público do Estado, com investimentos diretos ou empresas estatais, e também capitais privados internacionais ${ }^{112}$ e nacionais, formando-se um tripé.

O que se pretendia era promover o estabelecimento de indústrias no Brasil que fabricassem produtos até então importados. Visualizava-se um mercado já existente para determinados produtos e por meio de uma série de medidas protecionistas, incentivos e subsídios, encorajava-se tanto o capital nacional como o estrangeiro a construir indústrias no Brasil para substituir importações.

Esta atividade de investimento explica as elevadas taxas de crescimento dos anos cinqüenta (50), reforçadas pela política do governo brasileiro de estimular a integração vertical da estrutura industrial, estimular a indústria de bens de consumo e a indústria de bens de capital. A intenção era a de que a implantação destas indústrias substitutas nacionais criasse renda adicional. Dessa forma, quando o processo de substituição de importações chegasse ao fim (i.e. a relação importação/oferta global da maioria das indústrias atingisse níveis extremamente baixos), já se teria gerado renda suficiente para continuar o processo de crescimento industrial autóctone.

\footnotetext{
${ }^{110}$ Conforme Suzigan, W.: "No período a partir da década de 30, a ação do Estado em defesa do setor agrícolaexportador em crise (café) ajudou indiretamente o desenvolvimento industrial. A demanda de produtos manufaturados passou a crescer primordialmente em função da renda gerada nas atividades ligadas ao mercado interno, e o nível de renda foi mantido elevado por políticas macroeconômicas expansionistas em defesa do setor exportador." SUZIGAN, W. Estado e Industrialização no Brasil. Revista de Economia Política, São Paulo, Centro de Economia Política, 1988(8), p. 6.

${ }^{111}$ Conforme Furtado, "a industrialização de substituição de importações foi, sem lugar a dúvida, um processo reativo: tratou-se de encher um vazio. Uma demanda que florescera no quadro da economia primárioexportadora deu sentido e direção às transformações operadas no sistema produtivo. $\mathrm{O}$ declínio do coeficiente de comércio exterior não era outra coisa senão uma reversão do processo de especialização internacional. Como o voltar-se ao mercado nacional significa diversificação da atividade produtiva, a reversão assumia a forma de industrialização" (FURTADO, C. Estado e Empresas Transnacionais na Industrialização Periférica. Revista de Economia Política, São Paulo, Centro de Economia Política, 1981(1), p. 41).

${ }^{112}$ A política cambial da época acelerou o movimento de internacionalização do capital do pós-guerra e elevou a participação das empresas estrangeiras no setor industrial no Brasil.
} 
A política de substituição de importações consistiu em forçar a industrialização tanto do ponto de vista extensivo como intensivo, fortalecendo os elos internos, mas se descurando da modernização de outros setores da economia, especialmente a agricultura e dando pouca atenção a forças perturbadoras que estavam sendo produzidas pelas políticas do governo, especialmente as crescentes taxas de inflação ${ }^{113}$. A organização desta política ficou a cargo do Plano de Metas lançado pelo então governo de Juscelino Kubitschek, que previa a formação de "Grupos Executivos", por meio dos quais o governo brasileiro planejou, coordenou e financiou o desenvolvimento de algumas indústrias importantes, tais como, automobilística, construção naval, química e bens de capital, que se beneficiaram de incentivos e subsídios adicionais.

Parte do crescimento nos anos cinqüenta (50), em especial na segunda metade, foi proporcionado somente por um substancial influxo de capital estrangeiro, tanto sob a forma de investimento direto, como de empréstimos ${ }^{114}$. A estratégia utilizada foi fechar a economia, reservando o mercado para produtores locais, inclusive multinacionais ${ }^{115}$.

Suzigan conclui que o empresariado industrial brasileiro foi incutido de uma mentalidade protecionista, não tendo se preparado para que, ao fim do processo substitutivo de importações, tivéssemos uma indústria eficiente e competitiva, voltada para os mercados

\footnotetext{
${ }^{113}$ BAER, W. A Economia Brasileira. São Paulo: Nobel, 2007, p. 188.

${ }^{114}$ Por meio da Instrução 113 da Sumoc (Superintendência da Moeda e do Crédito) de 1955, permitiu-se às empresas estrangeiras importarem bens de capital sem cobertura cambial se o investidor estrangeiro aceitasse o valor (em moeda nacional) do equipamento como a participação de capital na empresa que fosse usar o equipamento. Isso beneficiou os investidores estrangeiros na medida em que eles evitavam os custos de transação e os custos diretos do mercado de câmbio. Vide CAPUTO, A. C.; DE MELO, H. A Industrialização Brasileira nos Anos de 1950: Uma Análise da Instrução 113 da Sumoc. Estudos Econômicos, São Paulo, 39(3): 513-538 jul.-set. 2009, p. 513 e ss.; GONÇALVES, R. Globalização Produtiva, Investimento Externo Direto e Empresas Transnacionais no Brasil: Uma Perspectiva Histórica. 2008. Disponível em: <http://www. reggen.org.br/midia/documents/globaprodutivaivesextdireto.pdf>. Acesso em: dez. 2009, p. 9.

${ }^{115}$ Furtado, C. analisa a atuação da empresas estrangeiras no processo de substituição de importações, atentando para o fato de que se utilizam de tecnologias já amortizadas e ultrapassadas no "centro" econômico global: "Ora, a tecnologia é a principal fonte do poder de mercado, razão pela qual aqueles que a controlam somente a cedam mediante condições muito restritivas. De maneira geral, as licenças de cessão dessa tecnologia não são mais que preparação de terreno, visando a uma implantação efetiva no mercado. Segue-se uma participação no capital da firma que utiliza esta tecnologia e finalmente seu controle. (...) Pela simples razão em que se "fecham" numa época em que no Centro a tecnologia orienta-se para a globalização, as economias periféricas tiveram que enfrentar, por toda parte, na fase da industrialização substitutiva, problemas de estreiteza de mercado ou de substituição de capacidade produtiva em múltiplos setores (...). A ação do Estado, conduzindo à descapitalização de certas indústrias de base durante uma primeira fase, permitiu contornar parcialmente esse obstáculo. No que respeita aos produtos finais, esse obstáculo se transformaria em arma eficaz na mão de empresas transnacionais, pelo fato de que podem utilizar tecnologia já amortizada e, em muitos casos, equipamentos total ou parcialmente amortizados. Nos setores em que a dimensão do mercado é insuficiente (...) as empresas transnacionais tendem a predominar ou são as únicas com condição de implantar-se. Para uma empresa local que devesse pagar a tecnologia ao preço de mercado e recuperar o capital investido nos prazos correntes, os custos de produção seriam demasiadamente elevados, o que agravaria a estreiteza do mercado" (FURTADO, C. Estado e Empresas Transnacionais na Industrialização Periférica, p. 44).
} 
interno e externo. A política de industrialização se caracterizava por um protecionismo exagerado e permanente. Isto resultou numa indústria com elevado grau de ineficiência, não competitiva interna e internacionalmente e com pouca ou nenhuma criatividade em termos tecnológicos. Não havia uma estratégia de desenvolvimento científico e tecnológico como parte das políticas de industrialização ${ }^{116}$. No que diz respeito à estratégia industrial das empresas transnacionais, Gonçalves afirma que: "não há como negar a ampliação do atraso tecnológico e organizacional das subsidiárias operando no Brasil" ${ }^{\text {"117. }}$.

As altas taxas de crescimento em 1960 e 1961 ainda refletiam o resultado da política de substituição de importação adotada ${ }^{118}$. Entretanto, a estratégia de desenvolvimento adotada nos anos cinqüenta (50) deixou uma herança a ser enfrentada pelos formuladores de política dos anos sessenta (60).

Houve uma industrialização muito rápida, mal planejada e excessivamente unilateral para que se pudesse sustentar. Nesse período, a dívida externa havia alcançado US\$ 2 bilhões (dois bilhões de dólares norte americanos), os pagamentos em juros e amortização e as remessas de lucros das empresas estrangeiras produziram crescentes pressões no balanço de pagamentos. O fato de a política de substituição de importações ter sido unilateral, tendo se descuidado da promoção de exportações e/ou da sua diversificação, estava se tornando um problema importante.

O crescimento industrial havia causado uma acentuação das desigualdades, com a distribuição desigual dos benefícios sob a ótica regional, setorial e das classes de renda. Havia sido causado também um atraso no sistema educacional, para o suprimento de pessoal melhor qualificado para o setor industrial.

\footnotetext{
116 "Juntamente com a política cambial, essas políticas favorecem taxas de rentabilidade mais elevadas no mercado interno em relação à exportação, criando, assim uma tendência à produção para o mercado interno. $\mathrm{O}$ resultado foi o desenvolvimento de uma indústria com elevado grau de ineficiência e, por isso mesmo nãocompetitiva interna e internacionalmente, e com pouca ou nenhuma criatividade em termos tecnológicos.

Essa ineficiência e não competitividade da indústria brasileira resultaram da ausência de uma estratégia de desenvolvimento científico e tecnológico como parte das políticas de industrialização implementadas a partir dos anos 50. (...) A proteção proporcionada constituía-se naquilo que Fajnzylber (1983) denomina 'protecionismo frívolo', no sentido de que não teve um objetivo de aprendizagem, apoiado num processo concomitante de geração de exportações e de desenvolvimento científico e tecnológico. A questão fundamental é que a substituição de importações não requer a absorção e desenvolvimento de tecnologia" (grifos nossos) (SUZIGAN, W. Estado e Industrialização no Brasil. Revista de Economia Política, São Paulo, Centro de Economia Política, 1988(8), p. 10 e ss.).

${ }^{117}$ GONÇALVES, R. Globalização Produtiva, Investimento Externo Direto e Empresas Transnacionais no Brasil: Uma Perspectiva Histórica, p. 15.

${ }^{118}$ BAER, W. A Economia Brasileira. São Paulo: Nobel, 2007, p. 181 e ss.
} 
Os anos iniciais dos sessenta trouxeram uma crise econômica, política e institucional produto da exaustão do modelo histórico de desenvolvimento que, nas três décadas precedentes, havia sustentado altas taxas de crescimento e engendrado profundas alterações estruturais na economia ${ }^{119}$. O breve governo de Jânio Quadros fez um esforço objetivando reformas estruturais e a estabilização, o que certamente contribuiu para sua renúncia. O período a partir da renúncia em agosto de 1961 até a deposição do governo João Goulart em abril de 1964 foi vazio de qualquer linha consistente de política econômica. Durante o governo Jânio Quadros, grupos que demandavam reformas institucionais básicas e políticas mais nacionalistas em relação ao capital estrangeiro tornaram-se crescentemente exigentes e tiveram influência substancial sobre o presidente. Foi demandado um controle maior sobre o capital estrangeiro (em alguns casos, desapropriação). Com as incertezas políticas, o investimento estrangeiro declinou.

Nesse contexto, em 1958 surge a primeira regra relevante na legislação brasileira controlando os pagamentos internacionais para a compra de tecnologia estrangeira. A Lei 3.470 de 28 de novembro de 1958, que altera a legislação do imposto de renda. Em seu artigo 74, dita as primeiras restrições legais à dedutibilidade de pagamentos por contratos de transferência de tecnologia. Exigia a lei, para os contratos de transferência de tecnologia, que fossem efetivamente prestados os serviços técnicos subjacentes. ${ }^{120}$ Ainda no mesmo ano, em 30 de dezembro de 1958, foi expedida a Portaria do Ministério da Fazenda 436/58, que regulamentou o art. 74 da Lei 3.470/58, fixando percentuais de dedutibilidade fiscal conforme o ramo da indústria que se pretendia fomentar ou, para usar os termos da regulação: “(...) considerando os tipos de produção ou atividade, segundo o grau de essencialidade". Espelhando o cenário econômico da época, à indústria de base eram designados os percentuais mais altos de dedutibilidade. Nota-se, assim, o vetor fiscal e cambial, direcionado à implementação da política de substituição de importações do nascimento da regulação.

\footnotetext{
${ }^{119}$ Vide LESSA, C. Prefácio. In: TAVARES, M. C. Da Substituição de Importações ao Capitalismo Financeiro Ensaios sobre Economia Brasileira. Rio de Janeiro: Zahar Editores, 1972.

${ }^{120}$ Ressalte-se que nesta época a previsão de averbação ou registro, a fim de produzir efeitos perante terceiros, pelo Departamento Nacional de Propriedade Industrial - DNPI de contratos que impliquem em transferência de tecnologia, i.e. assistência técnica, científica, administrativa e semelhante, não existia. O então Código da Propriedade Industrial trazia esta obrigação em relação a contratos de licença de direitos de propriedade industrial: marcas e patentes, somente.
} 
A doutrina da época manifestava-se favoravelmente à legislação. Gnocchi afirma haver um "desmando no campo da licença" e que o país estava "sedento de progresso, mas à justo preço". 121

Nesse período, institui-se uma severa lei de remessa de lucros. Aprovada pelo Congresso em outubro de 1962, com a Lei 4.131/62 instituiu-se o registro especial de capitais estrangeiros na moeda de origem na SUMOC, Superintendência da Moeda e do Crédito, que sistematizou o registro dos capitais estrangeiros ${ }^{122}$. Uma das principais características dessa Lei foi que ela não considerava como capital estrangeiro os lucros reinvestidos no país e, ao mesmo tempo, restringia as remessas de lucros conforme o fluxo de capital para o país nos anos anteriores. Essa lei foi regulamentada somente em janeiro de 1964, isto é, menos de três meses antes do golpe de estado e, portanto, nunca foi aplicada nos termos em que foi originalmente concebida $^{123}$.

Conforme o art. 9, os contratos que implicavam em transferência de tecnologia ficaram expressamente sujeitos a registro na SUMOC, a fim de permitir as remessas ao exterior. A mesma lei estipulava, ainda, que o registro averiguaria a efetividade da prestação dos serviços técnicos. $\mathrm{O}$ art. 14 estipulava uma proibição de remessa de royalties de marcas e patentes entre filial e matriz e entre subsidiária e matriz.

De 1962 a 1967, quando a pirâmide industrial já havia alcançado certa maturidade e haviam se esgotado as possibilidades da substituição de importações, os problemas de manutenção ou de expansão do nível de atividade industrial demandavam um aprofundamento e diversificação do consumo dos estratos de média e alta renda. Entra-se, assim, numa problemática da defesa do nível de renda, comum nas economias capitalistas

\footnotetext{
121 "É realmente extraordinário e, ao mesmo tempo, alarmante, o impulso que está tomando, no Brasil, a licença de patentes e de marcas estrangeiras. Tudo é feito à base de roialte e, à êste título, tem sido pagas, pelo Brasil, quantias fabulosas: em 1955196 milhões de dólares; em 1956275 milhões; em 1957350 milhões. Em três anos, uma cifra superior a 800 milhões de dólares. Pelos dados oficiais da Divisão do Imposto de Renda, o Brasil transferiu para o exterior, em 1956, à titulo de roialties, a cifra de $\mathrm{Cr} \$ 1.524 .200 .000,00$, da qual 52\% destinada aos Estados Unidos; $17 \%$ à Suíça; $11 \%$ à França, e a outros, 20\%. Como se vê, os Estados Unidos ocupam o primeiro lugar, com mais de $50 \%$.

Somente a quantia de 350 milhões de dólares remetida para o exterior em 1957, à titulo de roialte, é superior ao montante que o Brasil gasta com a importação de petróleo, trigo, fretes e seguros. Essa notícia deixou o Brasil perplexo. Vozes autorizadas se fizeram ouvir, reclamando a adoção de medidas de proteção à economia nacional. O "preço do progresso" estava custando sangue ao Brasil. (...)

(...) A lei 3470 de 28 de novembro de 1958 constitui a primeira reação ao desmando no campo da licença. É a primeira lei disciplinadora do roialte, em um país como o nosso, sedento de progresso, mas à justo preço" (GNOCCHI, A. Licenças e Roialties no Brasil. São Paulo: Revista dos Tribunais, 1960, p. 89 e ss.).

122 O Decreto-lei 9.025/46 já previa a necessidade de registro do capital estrangeiro na Carteira de Moeda de Câmbio do Banco do Brasil. Apos a criação do BACEN, o registro passou a ser realizado pela autarquia.

${ }^{123} \mathrm{O}$ Decreto 53.451/64 que havia regulamentado a Lei 4.131/62, acabou revogado pela Lei 4.390/64.
} 
maduras, mas precocemente colocada no Brasil. A nova problemática impõe uma reordenação nos processos de financiamento e produz, como resposta, a emergência do mercado de capitais.

Em abril de 1964, o novo governo de Castelo Branco formulou um governo de política econômica de curto prazo, o Plano de Ação Econômica do Governo - PAEG, que objetivava o controle da inflação e das distorções que haviam sido criadas no sistema econômico com a rápida substituição de importações e o longo período de inflação. Os principais objetivos do programa eram reduzir gradualmente a taxa de inflação, eliminar as distorções de preços e outras que a inflação havia produzido e modernizar os mercados financeiros, restaurando um clima de confiança do investidor na economia.

Não obstante, como conseqüência da falta de confiança na estabilidade política do país, nota-se significante redução da entrada do capital estrangeiro no Brasil. Apesar do PAEG, foi um período de persistência das altas taxas inflacionárias e da capacidade ociosa na indústria $^{124}$. Uma vez tendo se investido em uma estrutura industrial, é difícil alterá-la. As quantidades de capital empatados limitariam a escolha de caminhos futuros. Estagnação com inflação foi o fio condutor do período ${ }^{125}$.

Em agosto de 1964 o novo governo aprovou a Lei no 4.390, que alterava artigos da Lei no 4.131/62. Em 1964, a Lei 4.506/64 instaurou a regra da indedutibilidade dos pagamentos contratuais efetuados em contratos entre matriz e filial e também entre matriz e subsidiária também para os contratos de tecnologia não-patenteada. Os pagamentos indedutíveis já eram proibidos de serem remetidos pela lei 4.131/62, de forma que a lei proibiu a remessa de pagamentos contratuais ao exterior na hipótese de vínculo societário entre as partes contratuais. Ainda no mesmo ano, a Lei 4.595/64 vem regular o Sistema Financeiro Nacional, substituindo a SUMOC pelo Banco Central do Brasil. Procurava-se tornar a condução da política monetária mais independente ${ }^{126}$.

\footnotetext{
${ }^{124}$ Isso não obstante várias políticas do governo para impedir o aumento de preços - como por exemplo o condicionamento do patamar de preços à concessão de empréstimo às indústrias nos bancos do governo, também as siderúrgicas (em sua maioria de capital estatal) não eram autorizadas a elevar os preços.

${ }^{125}$ BAER, W. A Economia Brasileira. São Paulo: Nobel, 2007, p. 183 - parafraseando Mário Simonsen (Brazilian Inflation: Postwar experience and outcome of the 1964 Reforms - Economic Development Issues: Latin American Committee for Economic Development, Suplementary Paper, n. 21, Aug. 1967).

${ }^{126}$ A SUMOC era vinculada ao Banco do Brasil. Já o BACEN, cumpriria normas editadas pelo CMN (Conselho Monetário Nacional).
} 
No ano seguinte, o Decreto $55.762 / 65^{127}$ regulamentou as Leis 4.131/62 e 4.390/64, estipulando o Imposto Suplementar de Renda sobre o capital e re-investimentos registrados. Esse mesmo Decreto define o conceito de subsidiária para fins de limitação de dedutibilidade e proibição de remessas e estipula regras sobre a moeda na qual os pagamentos contratuais de tecnologia deverão ser remetidos.

Comentando a legislação, Pedreira afirma:

O pagamento de royalties ou assistência técnica, nessas hipóteses, era meio de diminuir o lucro tributável das sociedades brasileiras e fazer com que a remessa de lucros para o exterior ficasse sujeita apenas à incidência do imposto de $25 \%$ sobre rendimentos de residentes no exterior, sem a prévia incidência do imposto sobre lucro das pessoas jurídicas domiciliadas no país. ${ }^{128}$ (grifamos)

Ainda em 1966 o Decreto-Lei 37 institui a Lei do Similar Nacional, amparando a indústria nacional, pelo qual os produtos fabricados localmente eram registrados no Conselho de Política Aduaneira e habilitados à proteção contra importações através de tarifas mais elevadas. Continua-se, assim, com a regulação da transferência de tecnologia sob o vetor da política de substituição de importações, com lastro cambial e fiscal.

Em 1970 a Lei 5.648/70 cria o Instituto Nacional da Propriedade Industrial, assegurando-lhe poderes específicos para regular a transferência de tecnologia para o Brasil, promovendo-a. Conforme a exposição de motivos da Lei, reconhecia-se a participação elevada do know-how externo na industrialização brasileira. Institui-se sistematização específica para a regulação da transferência de tecnologia. Há um esboço de fortalecimento dos vetores propriedade intelectual e absorção e difusão de tecnologia, conforme a Exposição de Motivos da Lei. ${ }^{129}$

\footnotetext{
${ }^{127}$ O Decreto 53.451/64 que havia regulamentado a Lei 4.131/62, acabou revogado pela Lei 4.390/64.

${ }^{128}$ PEDREIRA, J .L. B. Imposto Sobre a Renda - Pessoas Jurídicas. Vol I. Rio de Janeiro: Justec, 1979, p. 396.

129 "As características do desenvolvimento econômico brasileiro acarretaram elevada participação do "knowhow" externo no atendimento da demanda tecnológica em suas diferentes etapas. Essa assimilação, embora tenha permitido o rápido crescimento de vários setores, nem sempre se tem apresentado em condições ideais para a solução de problemas tecnológicos característicos do atual estágio de desenvolvimento, tendo em vista a disponibilidade dos fatores de produção e a estrutura nacional de recursos.(...)

No sentido de acelerar o processo de transferência de tecnologia, impõe-se a necessidade da criação de um mecanismo eficiente, onde predominam a qualidade e a rapidez no exame dos privilégios e um adequado sistema de informações. Esse sistema deverá ter como objetivo procurar e distribuir informações à indústria, indicando ao adquirente da tecnologia a existência de alternativas, quer em termos de processos, quer de áreas de oferta.(...)

Para a execução dessa política faz-se necessária a transformação do Departamento Nacional da Propriedade Industrial em uma entidade suficientemente flexível, capaz de operar com o dinamismo que a moderna técnica requer" (grifamos). Em 8 de 04/09/1970.
} 
Em 1971 é promulgada a Lei 5.772/71, Código da Propriedade Industrial, que prevê expressamente a atribuição do INPI para o registro dos contratos de transferência de tecnologia, a fim de produzirem efeitos perante terceiros. Foi em 1972 que foi criada a área de contratos no INPI e que o INPI recebeu delegação de competência do Banco Central do Brasil para auxiliá-lo no controle cambial relativo à saída de divisas em pagamento de royalties e assistência técnica (Comunicado Firce 19 de 16/02/72). Antes disso, as remessas ao exterior eram autorizadas sem registro no INPI.

Não obstante preocupar-se em adotar padrões mais modernos de proteção à propriedade industrial, não havia na legislação preocupação expressa com a inovação tecnológica, voltada que estava a política econômica para a estabilização macroeconômica e substituição das importações. Denuncia-se, assim, a prevalência dos vetores fiscal, cambial e de substituição de importações sobre os vetores absorção e difusão do conhecimento e propriedade intelectual, não obstante a sistematização da regulação de transferência de tecnologia em torno do INPI.

A partir da crise do petróleo em 1973, a economia brasileira entra numa trajetória de desequilíbrio externo, que passou a ser determinante das políticas governamentais e da atuação das empresas. Nesse sentido, a orientação central da estratégia de ajuste passou a ser a redução do déficit na balança comercial. Os governos militares foram pródigos na concessão de estímulos à exportação, principalmente subsídios e incentivos fiscais, ao mesmo tempo em que aumentaram as barreiras de acesso ao mercado brasileiro, em particular, com utilização de medidas não-tarifárias ${ }^{130}$.

Entre 1974 e 1978 a política econômica tentava conciliar objetivos irreconciliáveis: Coutinho avalia que "Na primeira fase, entre 1974 e 1976, projetou-se um novo padrão de expansão, objetivando-se, de um lado, sustentar as elevadas taxas de crescimento e, de outro lado, reverter a aceleração da inflação e conter o déficit do balanço de pagamentos" ${ }^{\prime 31}$. Buscava-se alterar a estrutura da indústria brasileira para evitar a necessidade da importação de bens de capital e fortalecer a base exportadora. $\mathrm{O}$ crescimento econômico deveria ser sustentado por financiamentos. Uma política ambiciosa de gastos e política de crédito e financiamento de contenção. "Esta contradição manifestou-se num

\footnotetext{
${ }^{130}$ GONÇALVES, R. Globalização Produtiva, Investimento Externo Direto e Empresas Transnacionais no Brasil: Uma Perspectiva Histórica, p. 12.

${ }^{131}$ Trata-se do II PND ( Plano Nacional de Desenvolvimento).
} 
vaivém continuado". Ocorre forte elevação das taxas de juros aliada à entrada intensa de empréstimos estrangeiros ${ }^{132}$. Em 1974, a Instrução Normativa 5 da Secretaria da Receita Federal estipula que a averbação do contrato no INPI é necessária para que pagamentos contratuais fossem dedutíveis.

Em 1975 iniciam-se as reuniões sobre a criação de um Código Internacional de Conduta sobre Transferência de Tecnologia no âmbito da UNCTAD, da ONU ("TOT Code"). ${ }^{133}$ Desde o início, a gestação do TOT Code esteve vinculada com o direito latinoamericano sobre transferência de tecnologia. O texto de elaboração do TOT Code influiu nas alterações legislativas ocorridas na Argentina em 1974 e no Brasil em 1975. ${ }^{134}$ No ano de 1975, o Ato Normativo da Presidência do INPI 15/75 delineia diversas regras e políticas a serem adotadas pelo Instituto no registro dos contratos de transferência de tecnologia, inaugurando o que veio a ser comumente denominado de "dirigismo contratual". O Decreto 1.718/79 traz, em 1979, a obrigatoriedade de o INPI auxiliar a fiscalização dos tributos e prestar informações às autoridades fiscais quando assim solicitado. Assim como a regulação macroeconômica, nota-se a tentativa de conciliação de interesses inconciliáveis na atuação do INPI em relação à transferência de tecnologia. Ao mesmo tempo em que pretendia estimular a transferência de tecnologia (que tinha de vir de fora, pois não existia internamente), criava critérios de seleção de tecnologias prioritárias, dirigia fortemente as contratações privadas, aplicava a legislação cambial e fiscal com rigor, interpretando-a ainda mais restritivamente. ${ }^{135 \_}{ }^{136}$

O segundo choque do petróleo de 1979 fez com que o endividamento externo brasileiro crescesse com a mudança das condições de financiamento externo e elevação das taxas de juros do mercado internacional. Os anos oitenta protagonizaram diferentes medidas de ajustamento econômico, tanto no final do regime autoritário, quanto na fase da Nova

\footnotetext{
${ }^{132}$ COUTINHO, L. Inflexões e Crise da Política Econômica: 1974-1980. Revista de Economia Política, São Paulo, Centro de Economia Política, 1981(1), p. 77.

${ }^{133}$ Vide Capítulo I Item 6.2.

134 Vide CORREA, C. M. El derecho latinoamericano y la propuesta de regulación internacional de la transferência de tecnología: un análisis preliminar, p. 31 e ss.

${ }^{135}$ Vide Item 2.5 infra.

${ }^{136}$ CABANELLAS, G. J. Antitrust and direct regulation of international transfer of technology transactions: a comparison and evaluation, p. 15, explica que o surgimento da regulação da transferência de tecnologia no Brasil foi fortemente influenciada pela regulação em outros países da America Latina, a saber: Decisão 24 da Comissão do Acordo de Cartagena de 1970; as Leis Argentinas 19.231 e 20.794 de 1971, e a Lei Mexicana sobre o Registro de Contratos de Transferência de Tecnologia de 1972, tendo a América Latina se caracterizado por uma influência recíproca dos regimes e práticas adotados pelos países da região. A UNCTAD revela que o modelo latino-americano inspirou-se nos modelos do Japão e da República da Coréia (UNCTAD - United Nations Conference on Trade and Development. Transfer of Technology, p. 47).
} 
República. Todas fracassaram, dada a estagnação da renda per capita, a aceleração da inflação e aumento da dívida externa. "O período foi, inclusive, batizado de a década perdida"137. As empresas transnacionais reduziram significativamente seus investimentos no Brasil. Os dados indicam tendência de recuo principalmente via redução dos fluxos de entrada e aumento da repatriação de capital e das remessas de lucros. "O capital estrangeiro optou por uma estratégia de recuo gradual - retrenchment. Num contexto de profunda e longa crise econômica, houve uma desaceleração do crescimento do estoque de capital estrangeiro ao longo da "década perdida", 138 .

A crise macroeconômica, gerando estagnação e falta de acesso ao crédito estrangeiro, forçava o Governo a aceitar os preceitos estabelecidos pelo Consenso de Washington de liberalização, privatização e estabilização, que acabaram por encolher ainda mais o crescimento econômico ${ }^{139}$. Nos Estados Unidos e na Europa, uma nova onda liberal trouxe a estabilidade econômica e a retomada do crescimento. No Brasil, desigualdades de renda, limitações institucionais e crescente endividamento externo e interno impõem dificuldades ao exercício de política econômica liberal ${ }^{140}$.

Em 1988, promulga-se a nova Constituição Federal. A liberalização da economia brasileira tem início no fim da década de oitenta (80), eliminam-se barreiras não-tarifárias às importações, e reduzem-se tarifas médias e, ainda no início dos anos noventa (90), ocorre a liberalização de preços e desregulamentação setorial ${ }^{141}$.

A partir da década de 90 o Estado se retira da cena econômica por um processo vigoroso de privatização, não há uma agenda definida de política industrial, mas medidas pontuais, designadas pelo Estado a partir do delineamento do próprio setor industrial. $\mathrm{O}$

\footnotetext{
${ }^{137}$ PAIVA, P. Colloreconomics. Revista Brasileira de Economia, Rio de Janeiro, Fundação Getúlio Vargas, 1991(45), p. 35. Conforme Pereira, L. C. B.: "A aceleração da inflação nos últimos anos ocorreu enquanto a economia brasileira enfrenta a mais séria crise econômica de sua história industrial. A taxa de investimento caiu de 22/23 nos anos 70 para 16/17 por cento do PIB nos anos recesntes. Um desequilíbrio estrutural do setor público, cujo componente básico é uma enorme dívida pública externa, está pro trás da crise econômica. A aceleração da inflação no Brasil e seus altos níveis de atuais são um sintoma dessa crise, e são uma conseqüência indireta da crise fiscal do Estado brasileiro". PEREIRA, L. C. B. Os Dois Congelamentos de Preços no Brasil. Revista de Economia Política, São Paulo, Centro de Economia Política, 1988(8), p. 49.

${ }^{138}$ GONÇALVES, R. Globalização Produtiva, Investimento Externo Direto e Empresas Transnacionais no Brasil: Uma Perspectiva Histórica, p. 15.

${ }_{139}$ Apesar de opor-se ao Consenso de Washington na retórica, o Brasil claramente se submeteu, conforme as suas políticas implementadas na prática, aos elementos substanciais do conjunto de políticas. Sobre o impacto das políticas do Consenso de Washington nas economias latinas, vide STIGLITZ, J. Development Policies in a World of Globalization., p. 1.

${ }^{140}$ PAIVA, P. Colloreconomics, p. 36.

${ }^{141}$ FARINA, E. M. M. Q. Quatro Anos à Frente do CADE. Revista do IBRAC, São Paulo, 2009(16), p. 149.
} 
enfoque básico da Política Industrial e de Comércio Exterior, $\mathrm{PICE}^{142}$, foi o de criar condições que ampliassem a competitividade dos produtos e serviços brasileiros, por meio dela se deslocou o eixo da política industrial de aumento da capacidade produtiva para o aumento da competitividade $^{143}$. Há, portanto, maior valorização do papel do mercado como coordenador, dentro de uma ideologia de expor a indústria nacional à competitividade ${ }^{144}$. Embora as medidas de política econômica tenham conseguido estabilizar a moeda (o sucesso do Plano Real $^{145}$ traz de volta a estabilização de preços) e alterar substancialmente o padrão de concorrência das empresas locais, o padrão de investimento da economia se alterou ficando abaixo da média dos períodos anteriores. Além disso, o investimento externo direto se direcionou para setores orientados para o mercado interno com baixo impacto sobre os setores de ponta onde o progresso técnico e a incorporação de conhecimentos no aperfeiçoamento de produtos e de processos é essencial ${ }^{146}$.

A partir do final da década de oitenta e início da década de noventa ocorre o processo de desregulamentação cambial, onde há gradativa redução dos controles cambiais, com a simplificação das regras editadas pelo Banco Central do Brasil e menores exigências para as operações de câmbio.

Em 1991, com o advento da Lei 8.383/91, as remessas sob contratos de transferência de tecnologia entre subsidiária e matriz são liberadas, limitadas ao valor máximo de dedutibilidade. A proibição de qualquer remessa entre filial e matriz é mantida ${ }^{147}$.

Em 1994 o TRIPS é promulgado em território brasileiro (Decreto Legislativo 30/94 e Decreto 1.355/94). Também a Lei de Defesa da Concorrência (Lei 8.884/94).

Em 1995 há a reforma constitucional que equipara o tratamento do capital estrangeiro ao nacional e inicia a abertura de setores de interesse para o capital estrangeiro

\footnotetext{
${ }^{142}$ Medida Provisória 158/90 e Portaria 56 do MEFP.

${ }^{143}$ CASSIOLATO, J. E.; ELIAS, L. A. O Balanço de Pagamentos Tecnológicos Brasileiro: Evolução do Controle Governamental e Alguns Indicadores. In: VIOTTI, E. B.; MACEDO, M. de M. (org.). Indicadores de Ciência, Tecnologia e Inovação no Brasil. Campinas: Ed. Unicamp, 2003, p. 290.

${ }^{144}$ CAMPANÁRIO, M. de A. Intenções Implícitas da Nova Política Industrial Brasileira. 2004. Material distribuído como leitura na disciplina "Política Industrial e Tecnológica", do Programa de Pós-Graduação da Faculdade de Economia e Administração da USP, em 2006. Anotações de aula na disciplina "Política Industrial e Tecnológica”, do Programa de Pós-Graduação da Faculdade de Economia e Administração da USP.

${ }^{145}$ MP 434/94, reeditada e transformada em Lei: 8.880/95 e 9.069/95.

${ }^{146}$ VILLASCHI, A. Anos 90 - Uma década perdida para o sistema nacional de inovação brasileiro? São Paulo em Perspectiva, São Paulo, v. 19, n. 2, p. 3-20 abr.jun., 2005.

${ }^{147}$ Vide Item 4 supra.
} 
(cabotagem, telecomunicações, mineração, petróleo, etc.). Em dezembro, é promulgada a Lei 9.249/95, que elimina o imposto de renda sobre a remessa de lucros ao exterior ${ }^{148}$.

Em 1996 temos a introdução na legislação pátria da Lei da Propriedade Industrial (lei 9.279/96), adaptada aos padrões TRIPS, retirando parte das atribuições do INPI em relação à aceleração e promoção da transferência de tecnologia, mas mantendo sua atribuição de registro dos contratos respectivos ${ }^{149}$.

Em 1997 firma-se um Convênio entre o Instituto Nacional da Propriedade Industrial - INPI e o Conselho Administrativo de Defesa Econômica - CADE para cooperação na troca de informações, prevendo desenvolvimento de agenda de trabalho entre os dois órgãos.

Desponta a intenção do INPI de conferir um vetor concorrencial à regulação da transferência de tecnologia. Mas nada se altera na atuação, estagnada na "conciliação de interesses inconciliáveis" das décadas de setenta e oitenta. Abandona a "seleção de tecnologias prioritárias", mas continua a dirigir fortemente as contratações privadas e permanece com a mesma interpretação rigorosa e ampliativa da legislação cambial e fiscal. A qual, também em desalinho com a nova conjuntura macroeconômica, permanece em vigor.

A partir de 2000, com a liberalização e abertura da economia, uma política industrial em novas bases, que reconhece que os parques produtivos estão instalados e o ambiente de competição é internacional, desponta. Alcançada a estabilidade macroeconômica, trata-se agora, para a política industrial, de dotar as empresas nacionais de inovação e capacidade competitiva em outros patamares.

\footnotetext{
${ }^{148}$ CASsiOlato, J. E.; EliAS, L. A. O Balanço de Pagamentos Tecnológicos Brasileiro: Evolução do Controle Governamental e Alguns Indicadores, p. 292.

${ }^{149}$ A Exposição de Motivos (E.M. Interministerial 179 de 22 de abril de 1991) submete ao Presidente o anteprojeto de lei como resposta à Política Industrial e de Comércio Exterior, que pretende "criar um ambiente favorável aos investimentos, com o estabelecimento de regras claras e estáveis para o exercício da atividade econômica e o funcionamento do mercado". Os trabalhos para elaboração deste novo marco regulatório contaram com "representantes da iniciativa privada, interessados na matéria". Dispõe no item 27 que "[A] questão relativa à transferência de tecnologia foi tratada em consonância com as diretrizes da Política Industrial e de Comércio Exterior, buscando incentivar os processos de transferência e absorção de tecnologia, de importância crucial para que a indústria brasileira possa competir no exterior e oferecer ao consumo nacional produtos equivalentes àqueles a que têm acesso os cidadãos de outros países". No item 28 dispõe também: "Finalmente, é de se registrar a exclusão de dispositivos de natureza tributária e cambial relativos ao pagamento de 'regalias' pela exploração de patentes, pelo uso de marcas ou pela prestação de assistência técnica, por se tratar matéria estranha aos direitos e obrigações relativas à propriedade industrial, que o anteprojeto procura disciplinar."
} 
Em 2004 o Governo Federal divulgou a PITCE (Política Industrial, Tecnológica e de Comércio Exterior), como parte do PPA 2004-2007 (Plano Plurianual), que delineia a diretriz estratégica do Governo Federal. A PITCE foca em aumento da estrutura produtiva, capacidade de inovação e expansão das exportações como base para inserção do país no comércio internacional.

É editada a Resolução Normativa 61/2004 do Conselho Nacional de Imigração a qual condiciona a concessão do visto técnico temporário para técnicos estrangeiros ao treinamento que será fornecido aos funcionários da empresa brasileira ${ }^{150}$. Nota-se um vetor de absorção e difusão de tecnologia no delineamento desta política.

No mesmo ano, o Decreto 5.147/04, que normatiza as funções do INPI, volta a inserir expressamente a análise e decisão da averbação de contratos entre as atribuições da DIRTEC, vinculada às diretrizes de política industrial e tecnológica do Governo Federal. A exposição de motivos ${ }^{151}$ da regulação não é clara especificamente quanto aos contratos de

\footnotetext{
${ }^{150}$ Resolução Normativa 61/2004:

"Art. $1^{\circ}$ Ao estrangeiro que venha ao Brasil, sem vínculo empregatício com empresa nacional, para atendimento de situação de emergência, para transferência de tecnologia e/ou para prestação de serviço de assistência técnica, em decorrência de contrato, acordo de cooperação ou convênio, firmado entre pessoa jurídica estrangeira e pessoa jurídica brasileira, poderá ser concedida autorização de trabalho e o visto temporário previsto no inciso $\mathrm{V}$, do art. 13, da Lei 6.815, de 19 de agosto de 1980, alterada pela Lei 6.964, de 09 de dezembro de 1981, vedada a transformação em permanente.

Parágrafo único. Estão excluídas do conceito de assistência técnica as funções meramente administrativas, financeiras e gerenciais

"Art. $2^{\circ} \mathrm{O}$ pedido será formulado junto ao Ministério do Trabalho e Emprego, acompanhado dos seguintes documentos: (...)

IX - plano de treinamento detalhado e o número de brasileiros a serem treinados, em conformidade com o previsto no contrato, acordo ou convênio, especificando as qualificações profissionais do estrangeiro, o escopo do treinamento, sua forma de execução, o local onde será executado, o tempo de duração e os resultados esperados.

$\S 1^{\circ}$. Os documentos deverão indicar claramente seu objeto, demonstrando o programa para a transferência de tecnologia e/ou de treinamento no programa de assistência técnica a brasileiro, a remuneração a qualquer título, os prazos de vigência e de execução e as demais cláusulas e condições da contratação. (...)

Art. $3^{\circ}$ Para concessão de novas autorizações de trabalho e/ou prorrogação de autorizações existentes, deverão ser comprovados os resultados alcançados pelo Plano de Treinamento, previsto no inciso IX do art. $2^{\circ}$ da presente Resolução Normativa" (grifos nossos).

${ }^{151}$ Conforme a EM Interministerial 00178/MP/MDIC: "Há consenso na sociedade brasileira de que o desafio do crescimento econômico só poderá ser enfrentado mediante disseminação do uso dos mecanismos de geração de valor a partir do desenvolvimento e da proteção de ativos intangíveis (...)

As atuais deficiências do INPI já foram objeto de amplo debate (...). Em todas as instâncias houve plena convergência quanto à relevância central daquele órgão, particularmente para o funcionamento do sistema nacional de inovação (...)

É importante que o INPI seja cada vez mais capaz de contribuir tecnicamente na formulação das propostas e dos argumentos a serem considerados nas negociações internacionais e na instituição e revisão dos diplomas legais que regem a propriedade intelectual, de modo a assegurar que a regulação resultante seja sinérgica com as iniciativas de desenvolvimento tecnológico, econômico e social do País.

O INPI depara-se com uma série de dificuldades que decorrem, em grande parte, da baixa prioridade conferida, durante a década de 90 , aos temas ligados à política industrial.(...)"
} 
transferência de tecnologia, mas aponta a reorganização das funções do Instituto como uma resposta à nova política industrial.

A revisão do contexto histórico e econômico da regulação da transferência de tecnologia internacional no Brasil permite concluir que a realidade econômica contemporânea não se coaduna com a manutenção das linhas mestras interpretativas do vetor de substituição de importações, do vetor tributário e cambial, quando de sua instauração.

Quando da origem desta regulação, o país se encontrava em processo de industrialização planificada de substituição de importações, unilateral, pois voltado somente para o mercado interno, com uma característica forte de protecionismo exagerado e permanente. Não houve um esforço de alcanço dos padrões tecnológicos internacionais e desenvolvimento de inovações tecnológicas para a competitividade internacional da indústria local.

Ao contrário do que comumente se entende, as últimas duas décadas não foram de
declínio da política industrial. Ao contrário, incentivos e subsídios focaram em
exportações e investimento estrangeiro direto, na crença de que essas atividades são
a fonte de efeitos positivos. Assim, o desafio nos países em desenvolvimento não é
redescobrir a política industrial, mas aprender novamente como utilizá-la, de forma
mais eficaz. ${ }^{152}$

A atual realidade econômica urge por uma regulação com um enfoque diferente, que promova o desenvolvimento tecnológico brasileiro com base no encalço do padrão internacional e um forte destaque para a produção autóctone de inovação. Conforme analisaremos nos próximos Itens deste Capítulo, propomos a regulação pelos vetores da absorção e difusão de tecnologia e da instrumentalização da concorrência pela propriedade intelectual.

\section{Função do Instituto Nacional da Propriedade Industrial (INPI)}

O Instituto Nacional da Propriedade Industrial é a autarquia com atribuição legal de registrar os contratos de transferência de tecnologia que são objeto da presente tese ${ }^{153}$. Quando do registro do contrato, o INPI altera termos da contratação, fundamentando-se em normativos legais e administrativos. Analisaremos a seguir os respectivos normativos, a

\footnotetext{
${ }^{152}$ Vide RODRIK, D. Industrial Policy for the Twenty-First Century, p. 5.

${ }^{153}$ Contratos de transferência de tecnologia não patenteada e de prestação de serviços técnicos.
} 
atuação do INPI nestas contratações e a jurisprudência dos Tribunais em relação à atividade desenvolvida pelo INPI.

Concluiremos que a atuação do INPI desde os anos setenta permaneceu na "conciliação de interesses inconciliáveis": fomento de absorção de tecnologia localmente, mas desincentivando a transferência de tecnologia. Se a transferência é desincentivada, não há tecnologia para se fomentar a absorção. Nos anos noventa o INPI abandona a "seleção de tecnologias prioritárias", mas continua a dirigir fortemente as contratações privadas e permanece com a mesma interpretação rigorosa e ampliativa da legislação cambial e físcal.

Em virtude do fato de que a regulação de operações de transferência de tecnologia somente ter sido sistematizada pela legislação relacionando-a ao INPI, acabou por se disseminar a idéia de que operações não registráveis no INPI não constituiriam transferência de tecnologia. Não é verdade. Os conceitos de tecnologia e transferência de tecnologia, não definidos pelo direito, são amplos, conforme analisamos no Capítulo I deste trabalho, Itens 1 e 2 .

A fim de analisar a atuação do INPI em relação a essas operações, é preciso diferenciar inicialmente quais são as operações de transferência de tecnologia que estão sujeitas a registro no INPI. Conforme nossa argumentação ao longo deste trabalho, a regulação estatal, como parte da sua política industrial e tecnológica, submete somente algumas espécies de operação de transferência de tecnologia ao INPI.

\subsection{Exportação de Tecnologia}

O INPI não registra contratos de exportação de tecnologia brasileira para outros países. A exportação de tecnologia de uma empresa brasileira para uma empresa estrangeira ocorre por meio de um "contrato que implica em transferência de tecnologia", nos termos do art. 211 da Lei 9.279/96. Porém, na regulamentação da sua atividade, o INPI não incluiu esse tipo de contratação como sujeita a registro ${ }^{154}$.

\footnotetext{
${ }^{154}$ Ato Normativo 135/97 do Presidente do INPI. Conforme consta do site do INPI: "Por disposição legal devem ser Averbados/ Registrados pelo INPI todos os contratos que impliquem transferência de tecnologia, sejam entre empresas nacionais, ou entre empresas nacionais e sediadas ou domiciliadas no exterior.(...)
} 
A regulação da exportação da tecnologia deve basear-se em vetores delineadores diversos dos da importação de tecnologia. Ao contrário da difusão e absorção tecnológica, a preocupação seria com a manutenção da posição competitiva dos agentes econômicos brasileiros pelo controle da tecnologia, conforme analisamos no Item 5 do Capítulo ${ }^{155}$. Dado o atraso tecnológico em que o país se encontrava como decorrência da política unilateral de substituição de importações, é até mesmo previsível que os formuladores de políticas não tenham se preocupado com a regulação da exportação de tecnologia sob esse enfoque.

Em relação ao futuro, poderia haver um interesse no registro e regulação desses contratos no INPI, que controlaria os perfis de tecnologia exportados pelo país. Porém, entendemos que a prioridade atual é outra, a de absorção tecnológica gerada pela importação de tecnologia.

Tradicionalmente, a tutela no controle de exportação de tecnologia é direcionada a interesses políticos, na seara da segurança nacional ou de embargo comerciais. Em geral, são analisadas e fiscalizadas por órgão estatal específico, dentro dos controles de fronteira de um país. A obrigatoriedade de notificação da operação para registro pelo exportador, sujeitando-o a sanções específicas pelo descumprimento das leis de controle de exportações, é adotada pelos EUA ${ }^{156}$. A regulação da exportação de tecnologia na seara da segurança nacional está na seara de atribuições do Ministério da Defesa. ${ }^{157}$

Dada a dificuldade de se importar tecnologia pelo país na área militar, pois envolve interesses adicionais de restrição da transferência - muito além dos usuais do conflito

NOTA: São registrados apenas os contratos de assistência técnica em que o prestador de serviços é domiciliado no exterior. Assim sendo, os contratos internos e de exportação de SAT [serviços de assistência técnica], cujo prestador de serviço é uma empresa domiciliada no Brasil, não são registrados no INPI" (complementos em colchetes nossos) (Disponível em: <http://www.inpi.gov.br>. Acesso em 01/10/2009).

${ }^{155} \mathrm{O}$ conflito tecnológico norte-sul.

156 Vide: US Department of State / Directorate of Defense Trade Controls (Disponível em: <http://www.pmddtc.state.gov>. Acesso em julho de 2009). O Tratado de Wassenaar ou "The Wassenaar Arrangement on Export Controls for Conventional Arms and Dual-Use Goods and Technologies" é um regime de controle de exportações multilateral com 40 países participantes. É o successor do COCOM (Coordinating Committee for Multilateral Export Controls), tratado que vigorava na época da guerra fria e estabeleceu-se em 12 de Maio de 1996. O Brasil não é membro do Tratado de Wassenaar. O foco do tratado é promover a transparência dos controles nacionais de exportação. Possui uma lista de tecnologias restritas; divida em "Lista de Bens e Tecnologias de Uso Dual" (i.e. civil e militar) e Lista de Munições. Sobre controles militares na exportação de tecnologias vide: ALTIN-SIEBER, I. Joint Ventures, Technologietransfer und-schutz, p. 14 e 18.

${ }^{157}$ Conforme a Lei 10.683/03, alterada pela Lei 12.123/09, art. 27 inc. VII alínea o) constitui atribuição do Ministério da Defesa a "política nacional de exportação de produtos de defesa, bem como o fomento às atividades de pesquisa e desenvolvimento, produção e exportação em áreas de interesse da defesa e controle da exportação de produtos de defesa." 
norte-sul ${ }^{158}$ - o Ministério da Defesa do Brasil aprovou em 2002 "Política e Diretrizes de Compensação Comercial, Industrial e Tecnológica"159 . Com base no poder de compra do Estado quando da importação de produtos de defesa, deve-se exigir uma troca na forma de transferência de tecnologia para o desenvolvimento da Base Industrial de Defesa (BID) brasileira. Além disso, em 2009 delineia-se uma cooperação entre o Departamento de Ciência e Tecnologia do Ministério da Defesa e o INPI. A idéia é fomentar a utilização do sistema de propriedade industrial como fonte de informação e forma de proteção para as tecnologias desenvolvidas nos centros de pesquisa que funcionam no âmbito do Ministério da Defesa ${ }^{160}$.

\subsection{Importação de Tecnologia}

A atuação do INPI não se resume a qualquer contrato de importação de tecnologia estrangeira por parte brasileira. Somente algumas operações entre as inúmeras formas de transferência de tecnologia estão sujeitas a registro no INPI ${ }^{161}$.

Inexistindo definição na lei do que seja transferência de tecnologia, o delineamento do conceito para fins do registro é atribuição do INPI, desde que o faça amparado na legislação, dentro do respeito ao princípio da legalidade. O INPI tem (i) a função de "executar, no âmbito nacional, as normas que regulam a propriedade industrial, tendo em vista a sua função social, econômica, jurídica e técnica," 162 e a prerrogativa de (ii) "registrar contratos que impliquem em transferência de tecnologia para que produzam efeitos perante terceiros." ${ }^{163}$ No registro, deve "analisar e decidir quanto à averbação de modo alinhado às diretrizes de política industrial e tecnológica aprovadas pelo Governo Federal.”164

\footnotetext{
${ }^{158}$ Vide Capítulo I, Item 5.

${ }^{159}$ Portaria Normativa 764/MD. Conforme consta no site do Ministério da Defesa: “A Política de Compensação Industrial, Comercial e Tecnológica tem como objetivo coordenar as atividades que envolvem a utilização da ferramenta Offset em benefício do desenvolvimento industrial, tecnológico e de comércio exterior da Base Industrial de Defesa (BID) brasileira, a partir da utilização do poder de compra e o poder concedente do Estado, quando das importações de produtos de defesa" (disponível em: <www.defesa.gov.br/industria_defesa/index>. Acesso em: 14/11/2009).

${ }^{160}$ Fonte: <http://www.inpi.org.br>. Acesso em: 24/11/2009.

${ }^{161}$ Vide Capítulo I Item 2.

${ }^{162}$ Lei 5.648/70 Art. $2^{\circ}$.

${ }^{163}$ Lei 9.279/96 Art. 211.

${ }^{164}$ Decreto 5.147/04, Anexo I, Capítulo I, art. 13.
} 
Como autarquia vinculada ao Ministério do Desenvolvimento, da Indústria e do Comércio Exterior (MDIC) sua competência deriva da competência do próprio MDIC. A política do desenvolvimento da indústria, do comércio e dos serviços, bem como a propriedade intelectual e a transferência de tecnologia estão entre suas atribuições. ${ }^{165} \mathrm{O}$ registro do contrato pelo INPI ocorre como parte da política industrial e tecnológica do MIDC.

\subsection{Natureza da Tecnologia}

\subsubsection{Tecnologia da Área de Serviços}

O INPI estipula que a transferência de tecnologia refere-se a "conhecimento relacionado à produção industrial”. Apesar da definição do conceito pelo INPI mencionar a aquisição de conhecimentos para a produção de bens e serviços, logo em seguida há o mandamento de especificar "o setor industrial em que será aplicada a tecnologia". ${ }^{166}$ Numa primeira interpretação, entende-se que qualquer tecnologia utilizada para a produção e obtenção de bens e serviços seria passível de ser submetida ao órgão. Porém, o complemento da redação informando a necessidade de especificação do "setor industrial em que será aplicada a tecnologia", parece excluir a tecnologia de serviços. ${ }^{167} \mathrm{Na}$ prática, o posicionamento da DIRTEC é o de que contratos com tecnologia puramente relacionada ao setor de serviços não são passíveis de registro ${ }^{168}$.

\footnotetext{
${ }^{165}$ Lei 10.683/03 e alterações, Art. 27 inc. IX alíneas a) e b).

${ }^{166}$ Conforme <http://www.inpi.gov.br>: "Contratos que objetivam a aquisição de conhecimentos e de técnicas não amparados por direitos de propriedade industrial, destinados à produção de bens industriais e serviços. Esses contratos deverão conter uma indicação perfeita do produto, bem como o setor industrial em que será aplicada a tecnologia" (grifamos). Acesso em 15/07/2009.

${ }^{167}$ No modelo baseado em três setores, o desenvolvimento econômico obedece a uma seqüência natural em três tempos. A agricultura, pecuária, pesca e extrativismo mineral, ou setor primário, era, a princípio, o setor predominante em volume de produção e transação comerciais. Em seguida, veio o setor industrial, ou secundário, que se desenvolveu rapidamente visando substanciais melhorias da produtividade que provêm essencialmente das economias de escala, que levaram, conseqüentemente, ao desenvolvimento do setor de serviços, ou terciário. Este último setor amplia-se tão rapidamente e permeia o segundo gerando conflitos de definição sobre o que pertence a um e ao outro.

${ }^{168}$ A mera declaração de isenção de registro de um contrato possibilita às partes contratuais continuar com a contratação. Porém, pode não refletir a realidade da operação pretendida pelas partes. Na maioria das vezes estas operações revestem-se, então, do caráter de prestação de serviços simples, trazendo implicações tributárias ou de outra natureza às partes. É comum o fisco local, nos países de origem da tecnologia, exigir ou fiscalizar que a empresa efetivamente cobre royalties num patamar semelhante de todas as suas subsidiárias espalhadas pelo
} 
A proteção de uma tecnologia pela propriedade intelectual não discrimina o setor da economia. As diversas áreas do conhecimento humano, sejam aplicadas na agricultura, indústria e serviços recebem alguma forma de proteção. Especificamente no setor de serviços, não é possível patentear-se tecnologia. A proteção pela patente tem como pré-requisito a aplicabilidade industrial ${ }^{169}$. Esta é entendida como presente quando a tecnologia possa ser utilizada ou produzida em qualquer tipo de indústria ${ }^{170}$. Em qualquer gênero da indústria, inclui, em sentido amplo, o setor primário ${ }^{171}$, mas não o terciário ou de serviços.

O fato da tecnologia afeita à área de serviços não receber proteção patentária não lhe diminui a importância ou valor econômico per se. Com o desenvolvimento do setor de serviços na economia, a tecnologia relacionada às atividades de vendas e marketing torna-se tão valiosa quanto a industrial. Havendo sistematização desta tecnologia, ou seja, se o corpo de conhecimentos técnicos consegue se desvincular da empresa ou do núcleo de negócios onde foi gerada, sua transmissão a terceiros é usual e desejável.

Grande parte das tecnologias não patenteadas em circulação corresponde, inclusive, ao setor de serviços. A atribuição do MDIC refere-se à política de desenvolvimento da indústria, do comércio e dos serviços. Logo, deveria o INPI admitir tecnologias relacionadas a serviços em seu objeto de regulação.

Constava até há algum tempo no site do INPI lista de serviços não averbáveis como transferência de tecnologia ${ }^{172}$. A função da lista era orientar o usuário do sistema a fim de saber quando há necessidade submeter um contrato à averbação/registro. Constavam, exemplificativamente, as seguintes atividades ${ }^{173}$ :

\footnotetext{
- Agenciamento de compras, incluindo serviços de logística (suporte ao embarque, tarefas administrativas relacionadas à liberação alfandegária, etc.);

- Beneficiamento de produtos;
}

\footnotetext{
mundo. A não cobrança em determinado país ou a cobrança em patamares menores pode gerar pela lei fiscal local a imputação de receita (imputed royalties) e a respectiva cobrança do imposto de renda sobre o valor médio cobrado mundialmente. Outro problema que pode surgir, aqui no Brasil, é a questão da prova da prestação efetiva destes serviços para fins de dedutibilidade.

${ }^{169}$ Lei $9.279 / 96$, art. $8^{\text {o: }}$ "É patenteável a invenção que atenda aos requisitos de novidade, atividade inventiva e aplicação industrial".

${ }^{170}$ Lei $9.279 / 96$, art. 15 .

${ }^{171}$ Entendendo pela inclusão do setor primário: PONTES DE MIRANDA. Tratado de Direito Privado, p. 368; LABRUNIE, J. Direito de Patentes - Condições Legais de Obtenção e Nulidades, p. 70 e ss.

${ }^{172}$ Algumas das atividades relacionadas na lista realmente não implicariam uma transferência de tecnologia sistematizada, e sua inclusão na lista fazem sentido; exemplificativamente: agenciamento de compras, homologação e certificação de qualidade de produtos, consultoria jurídica ou financeira.

${ }^{173}$ Consulta ao site do INPI (http://www.inpi.gov.br) em junho de 1998. A autora não sabe esclarecer a partir de quando esta lista de serviços não averbáveis foi retirada do site.
} 
-Homologação e certificação de qualidade de produtos brasileiros, visando a exportação;

- Consultoria na área financeira;

- Consultoria na área comercial;

- Consultoria na área jurídica;

- Consultoria visando participação em licitação;

- Estudos de viabilidade econômica;

- Serviços de "marketing";

- Serviços realizados no exterior sem a presença de técnicos da empresa brasileira e, que não gerem quaisquer documentos e/ou relatórios;

- Serviços de manutenção de software sem a vinda de técnicos ao Brasil, prestados, por exemplo, através de 'help-desk';

- Licença de uso de software sem o fornecimento de documentação completa em especial o código-fonte comentado, conforme Art. 11, da Lei no 9609/98;

- Aquisição de cópia única de software;

- Distribuição de software.

O INPI registra corriqueiramente contratos relativos a operações de franquia, as quais operam primordialmente na área de serviços e comércio ${ }^{174}$. A Lei 9.279/96 reconheceu a franquia entre as operações que implicam transferência de tecnologia nos moldes do art. 211.

Embora contenham uma parcela de transferência de tecnologia, fornecimento de know-how, treinamento e assistência técnica, franquias empresariais são operações distintas da transferência de tecnologia pura. Envolvem obrigações típicas adicionais, tais como a licença de marca e a distribuição de produtos atrelada a um sistema típico de negócio ${ }^{175}$. A tecnologia inerente a uma operação de franquia certamente está sistematizada de forma clara, para que o modelo de negócios possa ser reproduzido por terceiros franqueados. Mas não é necessário exigir-se a caracterização de uma operação de franquia para que uma técnica na área de serviços possa ser reconhecida como revestida de sistematização, a qual lhe concederá o status de "tecnologia". 176

Independente das considerações sobre a conveniência de registrar no INPI tecnologias de serviços, que devem estar alinhadas a política industrial e tecnológica do

\footnotetext{
${ }^{174}$ Daí não se ter conhecimento de qualquer franquia instituída com base em uma patente e não em uma marca, apesar da expressa previsão legal de que a operação de franquia também se caracterizaria com a licença de uma patente (Lei 8.955/94, art. $2^{\circ}$ ).

${ }^{175}$ Conforme a Lei $8.955 / 94$, art. $2^{\text {o: }}$ "Franquia empresarial é o sistema pelo qual um franqueador cede ao franqueado o direito de uso de marca ou patente, associado ao direito de distribuição exclusiva ou semiexclusiva de produtos ou serviços e, eventualmente, também ao direito de uso de tecnologia de implantação e administração de negócio ou sistema operacional desenvolvidos ou detidos pelo franqueador, mediante remuneração direta ou indireta, sem que, no entanto, fique caracterizado vínculo empregatício. Vale ressaltar, porém, que quando inserida neste tipo de contratação, a tecnologia de serviços ou comércio entre empresas do mesmo grupo econômico tem a remuneração limitada pelo INPI a 1\%, conforme o item "Outros" da Portaria 436/58, assunto a ser tratado adiante no capítulo dedicado à regulação tributária.

${ }^{176}$ Vide Capítulo I, item 1.
} 
Governo Federal, ${ }^{177}$ é crucial que se aumente a segurança jurídica para os operadores do mercado por meio de normas claras quanto à necessidade ou não de registro no INPI. A edição de um normativo pelo INPI, expondo claramente os tipos de serviços técnicos que considera transferência de tecnologia ou não, é essencial.

\subsubsection{Programas de Computador e Serviços Correlatos}

Programas de computador incorporam tecnologia. A circulação desta tecnologia também é relevante para a economia e desenvolvimento do potencial técnico de um país, mas a escolha efetuada pelo Brasil para sua proteção foi aquela afeita ao direito autoral, sob uma lei específica, a Lei 9.609/98 (Lei de Software). ${ }^{178}$ Toda a regulamentação desta tecnologia é diferente da regulamentação da tecnologia que ficou sujeita à propriedade industrial. Além disso, há uma diferenciação quanto às regras do direito tributário e também das regras cambiais a que esta tecnologia está sujeita.

Porém, há situações em que mesmo esta tecnologia fica sujeita à regulamentação do INPI, provocando-se a coexistência de diferentes regulamentações para a mesma tecnologia. A intersecção de regulamentações começa com o art. 11 da própria Lei de Software (Lei 9.609/98):

\footnotetext{
Art. 11. Nos casos de transferência de tecnologia de programa de computador, o Instituto Nacional da Propriedade Industrial fará o registro dos respectivos contratos, para que produzam efeitos em relação a terceiros.
}

Parágrafo único. Para o registro de que trata este artigo, é obrigatória a entrega, por parte do fornecedor ao receptor de tecnologia, da documentação completa, em especial do código-fonte comentado, memorial descritivo, especificações

\footnotetext{
${ }^{177}$ Conforme RODRIK, D. Industrial Policy for the Twenty-First Century, p. 2: “As políticas de reestruturação da economia foram chamadas no passado de políticas industriais, mas entenda-se que o termo compreende outras áreas que não a indústria ou manufatura per se, tais como agricultura e serviços."

178 “Art. $2^{\circ} \mathrm{O}$ regime de proteção à propriedade intelectual de programa de computador é o conferido às obras literárias pela legislação de direitos autorais e conexos vigentes no País, observado o disposto nesta Lei.

$\S 1^{\circ}$ Não se aplicam ao programa de computador as disposições relativas aos direitos morais, ressalvado, a qualquer tempo, o direito do autor de reivindicar a paternidade do programa de computador e o direito do autor de opor-se a alterações não-autorizadas, quando estas impliquem deformação, mutilação ou outra modificação do programa de computador, que prejudiquem a sua honra ou a sua reputação.

$\S 2^{\circ}$ Fica assegurada a tutela dos direitos relativos a programa de computador pelo prazo de cinqüenta anos, contados a partir de $1^{\circ}$ de janeiro do ano subseqüente ao da sua publicação ou, na ausência desta, da sua criação. $\S 3^{\circ}$ A proteção aos direitos de que trata esta Lei independe de registro (...)".
} 
funcionais internas, diagramas, fluxogramas e outros dados técnicos necessários à absorção da tecnologia. (grifamos)

A Lei de Software remete a registro no INPI dos contratos de "transferência de tecnologia de programa de computador", para que produzam efeitos perante terceiros. A interpretação que o Instituto faz desse artigo, utilizando o seu parágrafo único como norte, é a de que qualquer contrato de licença ou comercialização de software no qual haja a transferência do código-fonte do programa de computador, será considerado um contrato de transferência de tecnologia, sujeito a registro no INPI. ${ }^{179}$

Grande incongruência de tratamento persiste também em relação a serviços técnicos envolvendo software. Esta incongruência ou sobreposição de regulamentações foi, em parte, gerada pelas próprias empresas contratantes, interessadas em viabilizar a vinda dos técnicos estrangeiros ao país para dar suporte ao programa de computador. Isso porque até 2004, sob a égide da Resolução Normativa 34/1999 do Conselho Nacional de Imigração, somente era possível obter-se visto temporário de assistência técnica para técnicos estrangeiros que viessem ao Brasil com base em contrato de serviços registrado no INPI. Como o registro no INPI era condição precedente para obtenção do visto para os técnicos, qualquer tipo de serviço técnico profissional era submetido ao INPI e desejava-se seu registro pelo órgão, caso contrário a vinda de técnicos ao Brasil restaria prejudicada. Atualmente, a competência para análise do contrato para fins de concessão do visto técnico é da Coordenação de Imigração do Ministério do Trabalho e Emprego, que analisa, ao mesmo tempo, o conteúdo do contrato de serviços técnicos e a viabilidade da concessão de autorização de trabalho e do visto para o técnico, com base no contrato. ${ }^{180}$

\footnotetext{
${ }^{179}$ Para um estudo sobre a caracterização de um programa de computador, conceituação de seus elementos técnicos e modalidades de programas de computador vide: DOS SANTOS, M. J. P. A Proteção Autoral de Programas de Computador. Rio de Janeiro: Lumen Juris, 2008, p. 25 e ss. Parece-nos que para que se caracterize uma transferência de tecnologia, utilizando-se o termo sem rigor técnico, em relação a um software é necessário analisar-se em primeiro lugar os termos contratuais. Estes indicarão se a parte receptora efetivamente está tendo acesso a informações e obtendo direitos que a permitirão dispor, comercializar e usufruir deste software como se o tivesse adquirido. A cessão do código-fonte certamente permite à parte que o recebe ter acesso à linguagem de programação do software, porém, contratualmente, pode não restar caracterizada uma transferência de tecnologia.

${ }^{180}$ Resolução Normativa 61/2004 do Conselho Nacional de Imigração. Conforme mencionamos no Item 1, deste Capítulo, neste ponto a regulação tem sido eficiente. O visto é concedido por um ano, renovável uma única vez por um ano adicional. A renovação do prazo do visto para o técnico estrangeiro é condicionada ao cumprimento do programa de treinamento da mão-de-obra local proposto.; negada em caso de não se atingir as metas propostas de treinamento durante o prazo contratual.
} 
Quanto aos serviços técnicos relacionados a programas de computador, o posicionamento da Diretoria de Transferência de Tecnologia e de Outros Registros do INPI DIRTEC é de que os serviços que não gerem relatórios ou produção de documentos não se enquadram como operação de transferência de tecnologia. Já os que gerarem relatórios ou documentos, envolvam a área de tecnologia da informação ou não, caracterizam-se como transferência de tecnologia e sujeitam-se a registro no Instituto.

Não consideramos esse ponto da regulação adequado. O fato de uma tecnologia abranger um programa de computador ou a área da tecnologia da informação deveria fazer com que ela se qualificasse inteiramente para o tratamento sob um sistema de regulação: cambial, tributário e de propriedade intelectual. Há de se lembrar que INPI é o Instituto Nacional da Propriedade Industrial e não intelectual. Não há uma alteração da natureza jurídica da tecnologia em si pelo fato de uma operação de software envolver a transferência de código fonte ou de serviços técnicos produzirem relatórios.

Caso haja uma opção política em aumentar o escrutínio sobre determinado tipo de contratação de transferência de tecnologia, é necessário criar-se uma regulamentação clara e uniforme, a fim de aumentar a segurança para os agentes do mercado. Trata-se, na nossa opinião, de opção do legislador em controlar determinado tipo de operação, para fins de política industrial. $^{181}$

\subsubsection{Tecnologia Não Protegida pela Propriedade Industrial - Ausência de Confidencialidade}

Há contratos em que o conteúdo tecnológico não está protegido por segredo de negócio, por ser a tecnologia de conhecimento público, ou em que a parte da tecnologia cujo conteúdo é confidencial é bastante reduzido. Conforme analisamos no respectivo item deste Capítulo, a confidencialidade é condição precedente para a proteção da informação como segredo de negócio, nos termos da legislação de propriedade industrial. ${ }^{182}$

\footnotetext{
${ }^{181}$ Vale ressaltar que somente em 1987, com a promulgação da Lei 7.646/87, o software recebeu proteção jurídica em território nacional. A política governamental desta área estava sob a égide da Secretaria Especial de Informática, SEI. Para análise da evolução histórica da proteção do programa de computador, vide: SANTOS, M. J. P. dos. A Proteção Autoral de Programas de Computador, p. 51 e ss.

${ }^{182}$ Capítulo I, Item 3.
} 
Claramente, o conceito de transferência de tecnologia independe de sua regulação por meio da propriedade intelectual. Há tecnologia e há transferência de tecnologia independentemente de se estar tratando de uma operação à luz da propriedade intelectual ou não. Exemplificativamente, na compra e venda de maquinário, em uma "joint venture" onde uma das partes entra com o modo de fabricação. ${ }^{183}$

O conceito de tecnologia é interdisciplinar e serve a diferentes funções. Certamente uma informação disponível a muitos possui um valor econômico inferior, mas a parte receptora pode ter interesse em receber esta informação juntamente com explicações adicionais e assistência na maneira como ela deve ser empregada ou implementada. Já expomos neste trabalho ${ }^{184}$ que ocorre uma operação de transferência de tecnologia toda vez que a prestação de serviços envolver ou implicar necessariamente uma técnica que a parte receptora tenha condições de absorver, por ser sistematizada.

Se o conteúdo em termos de propriedade industrial de um contrato de transferência de tecnologia é o segredo de negócio que a tecnologia incorpora, haveria por que submeter um contrato de uma tecnologia não confidencial ao Instituto Nacional da Propriedade Industrial, para registro? Isso porque o INPI tem como atribuição principal “(...) executar, no âmbito nacional, as normas que regulam a propriedade industrial, tendo em vista a sua função social, econômica, jurídica e técnica (...)."

Grande parte dos contratos de transferência de tecnologia que são submetidos ao INPI, mormente entre empresa relacionadas, é de tecnologias patenteadas em outros países, mas não no Brasil. Trata-se, então, de tecnologias já disponíveis ao público, pois o conceito de novidade é internacional e o acesso aos bancos de dados de patentes de cada um dos países do mundo é livre aos nacionais de outros países. Quando da autorização para utilização desta tecnologia em território brasileiro, utiliza-se como suporte contratual um contrato de transferência de tecnologia. Entendemos que se trata de transferência de tecnologia indireta, focada na aplicação prática dos conhecimentos não do conhecimento abstrato, pois que este já disponível. Logo, a classificação correta do tipo contratual nesta hipótese seria o de serviços técnicos e assistência técnica e não o de fornecimento de tecnologia industrial. ${ }^{186}$

\footnotetext{
${ }^{183}$ Vide Capítulo I, Item 3 deste trabalho.

${ }^{184}$ Capítulo I, Item 2.

${ }^{185}$ Lei 5.648/70 Art. $2^{\circ}$.

${ }^{186}$ Por conta da diferenciação entre operações de transferência de tecnologia não patenteada e licença de direitos de propriedade industrial é que os primeiros contratos estavam sujeitos a registro, até 1971, na SUMOC
} 
Foi somente a partir do final de 1970, com a criação do INPI (Lei 5.648/70), e em 1971, com a promulgação do Código de Propriedade Industrial (Lei 5.772/71), que referidos contratos tornaram-se sujeitos a registro em autarquia afeita à propriedade industrial, mas sem que o registro no Banco Central do Brasil fosse abolido, ficando os contratos de transferência de tecnologia com pagamentos contratuais ao exterior sujeitos ao duplo registro desde então.

Ocorre que qualquer contrato que implique em transferência de tecnologia está sujeito a registro no INPI, a menos que expressamente excluído por tratamento legal ou por política do Instituto, conforme os exemplos que verificamos acima quanto à tecnologia afeita ao software, aos serviços técnicos profissionais e à área da técnica em serviços. Não obstante o registro realizar-se atualmente pelo INPI, o vetor atual da regulamentação não está em questões de propriedade industrial, mas sim no vetor de substituição de importações, vetor fiscal e cambial. ${ }^{187}$

Aceitar ou não esse tipo de contrato para registro é algo que o INPI deve medir dentro dos objetivos de política industrial e tecnológica da nação e dos poderes que possui para a execução desta política. Entendemos que nesta hipótese, a atuação do INPI quando do registro do contrato estaria legitimada para: (i) classificar e enquadrar corretamente a contratação como serviços técnicos, já que o conteúdo de transferência de tecnologia estaria no ensinar a aplicação prática da tecnologia e não no transmitir a tecnologia já pública, e (ii) controlar e eventualmente eliminar cláusulas de confidencialidade que estejam presentes no instrumento contratual. A autarquia deve assumir os vetores de absorção e difusão de tecnologia e de instrumentalização da concorrência da regulação destas contratações no atual contexto econômico. $^{188}$

(Superintendência da Moeda e do Crédito - que veio a ser substituída pelo Banco Central do Brasil) e não no órgão encarregado de executar as normas de propriedade industrial. Isto demonstra o interesse do registro voltado à área fiscal e cambial e ao controle dos valores, prazos e forma dos pagamentos contratuais, mas não ao conteúdo de propriedade industrial.

${ }^{187}$ Vide Item 2.4.1 infra.

${ }^{188}$ Em acórdão proferido no ano de 1986, o Tribunal de Justiça de São Paulo entendeu impossível caracterizar-se um contrato como "cessão de know how, dado que este contrato pressupõe a existência de segredo industrial, o que não ocorre quando a técnica empregada caiu no domínio comum” (AP. 66.619-1 TJSP (4ª . Câmara Civil), Rel. Des. Alves Braga. RDM, ano XXV, n. 63, julho/setembro de 1986, p. 63 e ss.).

Ao comentar referida decisão, Silveira, N. corrobora o entendimento do Tribunal: "Se tais contratos se referissem a contratos e Know how, dos tipos previstos nos itens 4 e 5 do AN 15/75 [Ato Normativo 15/75 da Presidência do INPI] (fornecimento de tecnologia industrial ou cooperação técnico-industrial), a demonstrada ausência de novidade, ou caráter não secreto dos conhecimentos técnicos, que motivaram o cancelamento das patentes do apelante pelo INPI, igualmente inquinariam de nulos e sem objeto os contratos em questão" (esclarecimentos entre colchetes nossos) (SILVEIRA, N. INPI - Transferência de Tecnologia - Leis 5.648/70 e 5/772/71 - Averbação de contrato no INPI, p. 95 e ss.). 
Ao Governo cabe delinear de forma mais clara em sua política industrial o tipo e maneira de controles que pretende exercer sobre a importação de tecnologia para o país, e com qual finalidade. ${ }^{189}$ Adicionalmente, é preciso promover uma harmonização dos vários diplomas legais incidentes na operação para que expressem coerência entre si. A coerência será atingida na medida em que se escolham os vetores definidores da regulação de forma consistente.

\subsection{Registro ou Averbação do Contrato}

\subsubsection{Natureza Jurídica e Função do Registro}

Conforme a Lei 9.279/96, o registro dos contratos que impliquem em transferência de tecnologia no INPI torná-los-á aptos a produzirem efeitos perante terceiros. ${ }^{190}$ Logo, conforme o mandamento legal, não é o registro comum no Cartório de Registro de Títulos e Documentos, mas sim o registro no INPI. Ademais, não é qualquer contrato que corporifica operação de transferência de tecnologia que está sujeito a esse registro. Somente os contratos de transferência de tecnologia indicados pela lei e sua regulamentação, conforme analisamos nos Itens imediatamente anteriores.

\subsubsection{Os Termos "Registro" e "Averbação"}

A legislação utiliza-se indistintamente dos termos "registro" e "averbação" para definir o ato do INPI de revisão desses contratos. Enquanto o Art. 211 da Lei 9.279/96 referese a "registro", o certificado emitido pelo INPI denomina-se "Certificado de Averbação"191 . O

\footnotetext{
Não concordamos com ambas as posições. O julgado não analisa a questão da tecnologia e sua aplicação e interesse prático para a parte recipiente, ponto relevante e embasador da contratação. Conforme analisamos sob o Capítulo I, Item 3, o segredo industrial está abrangido no know-how, o qual, por sua vez, está abrangido pelo conceito de tecnologia. O termo know-how deriva da prática e implica mais do que segredo de negócio. A parte receptora tinha interesse no know-how, que por si só adquire, então, valor econômico.

${ }^{189}$ Analisando o TOT Code, verificamos que o setor de serviços foi incluído nas operações de transferência de tecnologia, conforme o Capítulo 1, Item1.2, alíneas (b) e (c). Vide considerações no Capítulo I, Subitem 2 deste trabalho. É preciso verificar se não é de interesse do país incluir estas tecnologias dentro do sistema de registro pelo INPI para fins de direcionamento da política industrial brasileira.

${ }^{190}$ Art. 211.

${ }^{191} \mathrm{Na}$ Lei 5.772/71, revogada, constava do art. 126 a "averbação" pelo INPI dos contratos que impliquem em transferência de tecnologia.
} 
Comunicado Firce 19/72 do Banco Central do Brasil refere-se a documento que tenha sido "averbado" pelo INPI. A Instrução Normativa da 5/74 da Secretaria da Receita Federal referese à "averbação" do contrato. A Lei 8.383/91 art. 50 refere-se a contratos "averbados" no INPI. O Decreto 3.000/99 $9^{192}$ (Regulamento do Imposto de Renda) dispõe no $\S 3^{\circ}$ do art. 355 sobre a "averbação" do contrato. O art. 13 do Anexo I do Decreto 5.147/04 menciona "averbação" do contrato.

Aparentemente utilizados como sinônimos, os termos "averbação" e "registro" possuem ligeira diferenciação em significado. Na averbação, "anota-se à margem de um assento ou documento fatos que alteram, modificam ou ampliam o conteúdo do mesmo assento ou documento". A averbação "tem a mesma função do registro originário, i. e. o de dar publicidade ao ato averbado." ${ }^{\prime 193}$ Conclui-se, portanto, que a averbação pressupõe um registro, pois que feita à sua margem. ${ }^{194}$

O registro tem a finalidade de assegurar a autenticidade, segurança e validade dos atos jurídicos ${ }^{195}$. A autenticidade e segurança são utilizadas no sentido de libertação do risco de não-veracidade das informações, por ser um sistema de controle que, inclusive, impõe remissões entre os vários registros públicos como obrigatórias, de forma que se constitua "malha firme e completa de informações". Ao promover o registro, influenciamos a eficácia do documento: “(...) relações jurídicas existem que exigem ser respeitadas por terceiros, sendo imperiosa a necessidade da criação de um órgão, de um sistema capaz de possibilitar êsse conhecimento erga omnes"196. A eficácia é, portanto, relacionada à aptidão de produzir efeitos jurídicos perante terceiros, mas não entre as partes, pois que o registro do ato jurídico não tem o condão de afetar-lhe a existência.

A legislação específica de propriedade industrial evoluiu na referência ao ato de revisão dos contratos de transferência de tecnologia, de "averbação" 197 para "registro" "198. Já

\footnotetext{
${ }^{192}$ O RIR/75 dispunha de maneira idêntica sob o art. 177 § $3^{\circ}$, bem como o RIR/80 e RIR/94.

${ }^{193}$ Enciclopédia Saraiva do Direito, coordenação do Prof. Limongi França. São Paulo, Saraiva, 1978, p. 482.

194 A doutrina difere "averbação" de "anotação" e "retificação". A averbação é nota marginal, mas com função de alterar ou modificar a substância do objeto do registro. Já a anotação e retificação referem-se aos casos em que a nota à margem tem função mais restrita, justamente de retificar ou anotar. Comum na forma, averbação, retificação e anotação diferem na substância. Vide: Repertório Enciclopédico do Direito Brasileiro por J. M. De Carvalho Santos coadjuvado por José de Aguiar Dias. Rio de Janeiro: Borsoi, Volume V, p. 246.

${ }^{195}$ Lei $6.015 / 73$, art. $1^{\circ}$.

${ }^{196}$ Nossos complementos entre colchetes. Repertório Enciclopédico do Direito Brasileiro por J. M. De Carvalho Santos coadjuvado por José de Aguiar Dias. Rio de Janeiro: Borsoi, Volume XLVIII, p. 5.

${ }^{197}$ Lei $5.772 / 71$, art. 126.

${ }^{198}$ Lei 9.279/96, art. 211.
} 
os contratos de licença de marcas, patentes e desenhos industriais permaneceram com a denominação "averbação" ao longo das leis de 1972 e $1996^{199}$.

Parte da doutrina entende que a evolução do termo utilizado na legislação para o ato do INPI em relação aos contratos de transferência de tecnologia de "averbação" para "registro" reflete a intenção do legislador de alterar o regime de verificação dos contratos ${ }^{200}$. Certamente houve um esboço de intenção de alteração desse regime, mas não pela mera substituição de um termo pelo outro. Na realidade, a Lei 9.279/96 modificou a Lei 5.648/70, lei de criação do INPI, especificamente no tocante à transferência de tecnologia. Assim, no contexto de modificação da redação dos artigos das leis específicas, o regime de análise dos contratos se alterou. Analisaremos a evolução da regulamentação das atividades do INPI nos Itens 2.5 e 2.5.1, infra.

À titulo de conclusão, entendemos que o termo "registro" é mais adequado para designar as atividades de verificação desses contratos pelo INPI. O termo averbação faz sentido em relação a um contrato de licença de direito de propriedade industrial, por inferir a anotação à margem do registro do direito mesmo ${ }^{201}$. É inadequado usar-se "averbação" para o contrato de transferência de tecnologia, pois a tecnologia não patenteada está sujeita a outro regime de proteção, que é o de concorrência desleal, conforme analisamos no Capítulo I Item 3 supra; a legislação específica que institui a necessidade de registro do contrato, Lei 9.279/96 art. 211, utiliza-se do termo registro. Logo, este é o que deveria ser adotado pela regulação.

\footnotetext{
${ }^{199}$ Lei 5.772/71, art. $30 \S$ único, art. $90 \S \S 3^{\circ}$ e $4^{\circ}$; Lei $9.279 / 96$, art. $62 \S \S 1^{\circ}$ e $2^{\circ}$, art. 121 , art. $140 \S \S 1^{\circ}$ e $2^{\circ}$, art. 141. Interessante notar que o caput do art. 30 da Lei 5.772/71 previa a averbação tanto da aquisição do privilégio quanto da concessão de licença de exploração de patente. Provavelmente aí se encontre a origem do uso da expressão averbação. Há um registro no INPI do direito de patente e do direito de marca, mas não há um registro no INPI da tecnologia não-patenteada ou do know-how, já que não constitui um direito de propriedade. Então, o contrato de uso do know-how não teria um registro original onde pudesse ser averbado. Entendemos que o termo averbação faria sentido se a licença de exploração ou uso do direito estivesse averbada à margem do registro da patente ou da marca. Porém, não é o que ocorre, já que a averbação de contratos é atribuição de diretoria distinta no INPI, que mantém arquivos e "registros" separados: DIRTEC - Diretoria de Transferência de Tecnologia e Outros Registros do INPI.

${ }^{200}$ BASTOS, A. W. C. (organização e pesquisa). Dicionário Brasileiro de Propriedade Industrial e Assuntos Conexos. Rio de Janeiro: Lumen Juris, 1997, p. 265.

${ }^{201}$ Pelo fato de diretorias distintas do INPI cuidarem do registro do direito de propriedade industrial e do contrato de licença deste direito, a existência do contrato de licença não é averbada à margem do registro da marca e da patente, por exemplo. Neste sentido, nossa sugestão é a utilização da expressão "registro" para a atuação do INPI em relação a todos os contratos sob a Lei 9.279/96.
} 


\subsubsection{Produção de Efeitos Perante Terceiros}

A Lei de Registros Públicos (Lei 6.015/73) estipula que o registro tem a função de conceder aos atos jurídicos autenticidade, segurança e eficácia ${ }^{202}$. Determina, ainda, que os registros da legislação civil não mencionados expressamente ficam sujeitos à legislação própria $^{203}$.

Assim, o alcance do significado de "produção de efeitos perante terceiros" para o registro do contrato de transferência de tecnologia no INPI deve ser inferido da própria Lei 9.279/96, bem como de toda a legislação que regulamenta esse registro - seja a legislação de criação do INPI, a legislação fiscal, cambial e os normativos administrativos das autoridades responsáveis.

O termo "terceiro" deve ser entendido como todos aqueles que não as próprias partes da contratação. Em relação às partes, o instrumento privado de acordo de vontades produz efeitos desde a sua assinatura ${ }^{204}$. Possui, assim, o contrato, eficácia simples a partir de sua assinatura. Do registro no INPI dependerá sua eficácia relativa. ${ }^{205}$

$\mathrm{O}$ ato de registro público de contrato de transferência de tecnologia parece contradizer a própria operação de transferência de tecnologia. Contratos de transferência de tecnologia propriamente ditos, i.e. aqueles que têm como objeto o fornecimento de segredo de negócio (i.e. excluindo-se os contratos de serviços técnicos) ${ }^{206}$, tem a confidencialidade como condição precedente de operacionalização, sob a conseqüência de perda do valor econômico da informação ${ }^{207}$. Logo, a regra deveria ser a de não se registrar contratos de transferência de tecnologia $^{208}$.

\footnotetext{
${ }^{202}$ Lei $6.015 / 73$, art. $1^{\circ}$.

${ }^{203}$ Lei $6.015 / 73$, art. $1^{\circ}, \S 2^{\circ}$.

${ }^{204}$ Desde que não eivado de algum vício de nulidade, como qualquer instrumento privado de acordo entre as partes.

${ }^{205}$ Vide JUNQUEIRA DE AZEVEDO, A. Negócio Jurídico - Existência, Validade e Eficácia. 2. ed. São Paulo: Saraiva, 1986, p. 63, e TINOCO SOARES, J. C. Lei de Patentes, Marcas e Direitos Conexos. São Paulo: Revista dos Tribunais, 1997, p. 228. Na jurisprudência, há menção específica em relação a contrato de licença de marcas: "Ocorre que o contrato de licença não foi averbado junto ao INPI, motivo pelo qual, perante terceiros, entre os quais a cessionária dos direitos sobre a marca, o negócio não produz efeitos, nos exatos termos do art. 140 da Lei 9.279/96." Recurso Especial 606.443 - SP (2.003/0204088-5) - Superior Tribunal de Justiça.

${ }^{206}$ Vide Capítulo I, Itens 2 e 3.

${ }^{207}$ Vide Capítulo I, Item 3.

${ }^{208}$ Vale ressaltar que pelo fato da necessidade de registro do contrato no INPI, ainda que ele não tenha como conseqüência a publicidade integral do documento (vide Item 2.4.2 infra), tem-se por praxe não incluir no documento que vai para registro as informações tecnológicas em si mesmas. A regulamentação entre as partes da entrega e lista dos documentos contendo as informações tecnológicas, parte crucial de uma operação de transferência de tecnologia, acaba ocorrendo à parte, por instrumentos separados.
} 
Havendo interesse em opor cláusulas contratuais a terceiros, poder-se-ia em tese recorrer ao registro usual no cartório de registro de títulos e documentos, que não exclui qualquer categoria de documento da faculdade de registro ${ }^{209}$. Entretanto, o art. 211 da Lei 9.279/96 tem como efeito tornar somente o registro no INPI do contrato ato válido para que o contrato produza efeitos perante terceiros ${ }^{210}$.

Interpretando-se a legislação que regula a atuação do INPI quando do registro, conclui-se que o interesse na produção de efeitos perante terceiros para as partes contratuais reside nos efeitos fiscais e cambiais que o contrato passará a produzir e na regulação em termos de política industrial e tecnológica. Não é usual que se tenha que registrar um contrato para que sua cláusula de pagamento seja válida perante as autoridades fiscais e cambiais. Portanto, diferentemente do registro de documentos sob a Lei 6.015/73, facultativo, o registro do contrato de transferência de tecnologia no INPI é, na realidade, obrigatório para contratos onerosos.

Além da cláusula de pagamentos, outras cláusulas usuais ${ }^{211}$ em um contrato de transferência de tecnologia são: cláusulas de confidencialidade, cláusulas de exclusividade e de limitação de escopo geográfico ou territorial de atuação no uso da tecnologia, cláusulas relativas à legitimação da parte brasileira para agir em juízo em defesa da parte estrangeira, relativamente à sua posição no contrato. Entendemos que o registro do contrato, executado dentro de uma finalidade de política industrial e tecnológica, implicaria, em relação a cláusulas de exclusividade, confidencialidade e limitação de território, a revisão de harmonização das cláusulas com o interesse público atinente ao direito da concorrência.

Assim, estar-se-ia dentro de uma função de revisão de cláusulas a fim de verificar sua harmonia com a legislação nacional, tendo como embasamento o interesse público de promoção da livre-concorrência, incluindo, na função de promoção da concorrência nos

\footnotetext{
${ }^{209}$ Lei 6.015/73 Art. 127: "No Registro de Títulos e Documentos será feita a transcrição:

I - dos instrumentos particulares, para a prova das obrigações convencionais de qualquer valor; (...)

VII - facultativo, de quaisquer documentos, para sua conservação."

${ }^{210}$ Vide FRANCO, V. H. De M. Contratos de Transferência de Tecnologia: Intervenção Estatal e Tutela Legal. Revista de Direito Mercantil, São Paulo, ano VXIII (nova série) 1979(33), p. 63.

${ }^{211}$ Contratos de transferência de tecnologia não obedecem a uma padronização de cláusulas típica, a sua forma de contratação é variada. Conforme a Coordenadora Geral de Contratos de Transferência de Tecnologia, da Diretoria de Transferência de Tecnologia Contratos e de Outros Registros, DIRTEC, Lia de Medeiros: "Em transferência de tecnologia, a possibilidade de adoção de um modelo contratual é remota ou mesmo impossível. Comumente, tem-se: I - Partes; II - Considerações; III - Definições; IV - Objeto; V - Território; VI Confidencialidade; VII - Pagamentos; VIII - Assistência Técnica; IX - Lei Aplicável; XI - Arbitragem. Palestra Propriedade Intelectual e Transferência de Tecnologia, proferida em 21 de junho de 2007, no painel Setorial da Inmetro. Disponível em: <www.inmetro.gov.br/painelsetorial/palestras/INPI.pdf>. Acesso em: 18/09/2009.
} 
mercados, a necessidade de absorção e difusão de tecnologia. No âmbito da União Européia, a regulamentação destas cláusulas em contratos de transferência de tecnologia já existe e está em sua terceira versão ${ }^{212}$.

Analisaremos a questão da intersecção entre a legislação da propriedade industrial e do direito da concorrência, bem como de sua aplicação na revisão dos contratos de transferência de tecnologia, no Capítulo III infra.

\subsubsection{Conteúdo do Certificado de Averbação}

O processo de registro do contrato de transferência de tecnologia no INPI culmina com a emissão de Certificado de Averbação $^{213}$ e publicação na Revista da Propriedade Industrial dos termos do Certificado de Averbação.

Enquanto no registro comum de títulos e documentos há uma transcrição do documento de forma integral e qualquer indivíduo pode requerer uma certidão de inteiro teor do mesmo $^{214}$, o registro no INPI opera de forma diferente. O conteúdo integral de um processo de registro de contrato de transferência de tecnologia não é acessível a quaisquer terceiros. Somente as partes podem requerer cópias de documentos arquivados.

O Certificado de Averbação é emitido e entregue à parte requerente do registro. Ele enumera dados específicos da contratação: partes, objeto, prazo, remuneração, responsabilidade pelo pagamento do imposto de renda. Os itens pertinentes a pagamento e prazo são incluídos conforme a legislação tributária e cambial aplicável, independente do conteúdo do contrato assinado pelas partes. Assim, o Certificado de Averbação determina a área de classificação da tecnologia, o percentual do pagamento, o prazo contratual, muitas vezes alterando os termos contratuais ${ }^{215}$. Explicações sobre derivações entre as cláusulas

\footnotetext{
${ }^{212}$ Vide Capítulo III Item 3.

${ }^{213}$ Contrariamente ao que dispõe o art. 211 da Lei 9.279/96, o Certificado que o INPI emite ao registrar o contrato de transferência de tecnologia vem com o nome de Certificado de Averbação e não Certificado de Registro.

${ }^{214}$ Lei 6.015/73, Art. 17: "Qualquer pessoa pode requerer certidão do registro sem informar ao oficial ou ao funcionário o motivo ou interesse do pedido."

${ }^{215}$ É comum o INPI emitir "exigência" no curso de um pedido de registro de contrato de transferência de tecnologia, requerendo esclarecimentos sobre as cláusulas contratuais ou até mesmo solicitando execução de
} 
contratuais e o conteúdo do Certificado de Averbação são incluídas no item "Observações" do Certificado de Averbação e/ou em carta separada, emitida pela respectiva Diretoria do INPI, a qual é mencionada no próprio Certificado de Averbação como "parte integrante do Certificado".

Na Revista da Propriedade Industrial (RPI), de ampla e irrestrita circulação, é publicada versão reduzida dos termos do Certificado de Averbação, onde é possível identificar as partes contratuais, a tecnologia, o valor e o prazo.

Concluímos que a intenção do registro no INPI é regulatória e com objetivo que vai além da finalidade de "autenticidade, segurança e eficácia" usual dos registros que conferem fé pública a documentos. Ele está vinculado ao exercício de política industrial pelo Poder Executivo, especificamente pelo Ministério do Desenvolvimento, Comércio e Indústria, ao qual a autarquia está vinculada. Não obstante a utilização do termo "registro", não se pode inferir que a Lei 9.279/96 tornou o INPI mero órgão registral.

Conforme descrito acima, quando do registro há uma ingerência efetiva da autarquia nas operações contratadas pelos particulares. A fim de legitimar referida ingerência, é preciso que a legislação a respalde.

\subsection{Análise da Legislação que Confere Suporte às Atividades do INPI}

Norteando a atuação da administração pública, temos o princípio da legalidade administrativa, que pode ser diferenciado entre o princípio do primado da lei e o princípio da reserva legal. O princípio do primado da lei infere a submissão da administração pública à lei, e impõe um limite negativo à atividade administrativa. Já o princípio da reserva legal resguarda determinadas condutas e as submete ao domínio da lei em sentido estrito. Assim, o INPI, ao exercer seu poder regulamentar de autarquia, não pode ir além da delegação de poderes que recebeu por lei, adentrando aspectos das relações contratuais sem que haja um embasamento legal para sua ação.

aditivo pelas partes, condicionando o registro à apresentação do aditivo contratual, que modifique cláusulas não condizentes com sua política em relação aos contratos de transferência de tecnologia. 
Como autarquia vinculada ao Ministério do Desenvolvimento, da Indústria e do Comércio Exterior, a atuação do Instituto deve harmonizar-se, em primeiro lugar, com o escopo de funções designadas a esse Ministério pela Presidência da República e, em segundo lugar, com as funções que o próprio Ministério lhe incumbir.

\section{A atuação do INPI é restrita ao mercado de propriedade industrial e de} transferência de tecnologia. Em razão de sua especificidade, o mercado de propriedade industrial e transferência de tecnologia tem uma regulação particular, sendo função do INPI institucionalizá-lo ${ }^{216}$. Assim, o INPI regulamenta o mercado, emite atos, fiscaliza e adjudica. $^{217}$

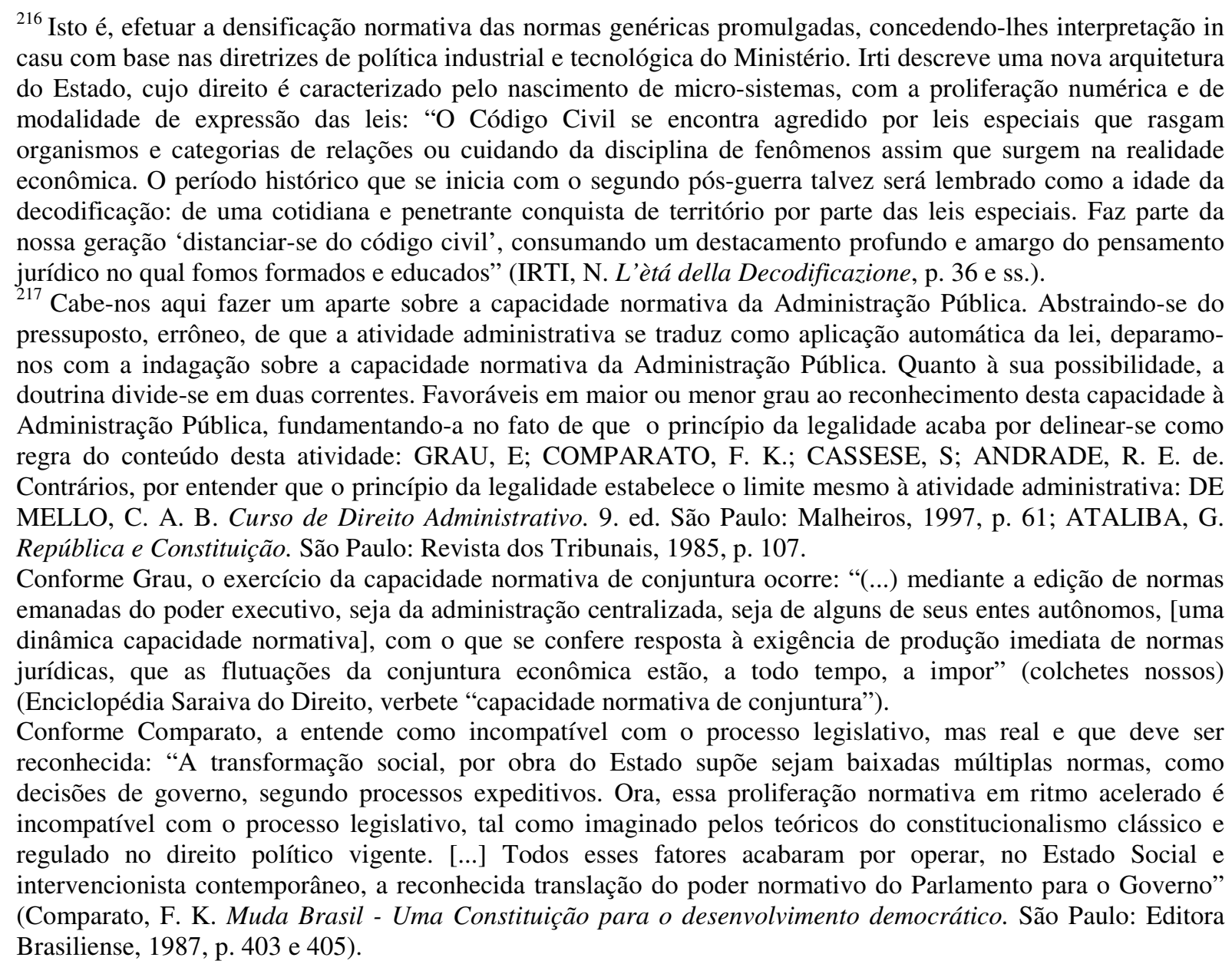
Cassese observa: "Los parlamentos y los gobiernos han visto ampliarse su representatividad popular (sufrágio universal). Pero, con relación a su dimensión y al numero de normas producidas cada año, o bien se han quedado parados o bien han progresado poco respecto al siglo pasado. Incluso los aparatos judiciales han permanecido estabilizados o han aumentado en menor medida que el aumento de la población y del crecimiento económico. Solo las Administraciones se han desarrollado en mayor medida que el aumento de población (de cerca del 1 por 100 a cerca del 10 por 100). En la ordenación de los poderes públicos, por tanto, los poderes legislativo y judicial están en una posición recesiva con relación al poder administrativo. Todo ello ha sido destacado por aquellos - partindo de Hans Kelsen en 1923 y de Carl Schmitt - que han hablado del Estado moderno como Verwaltungsstaat o 'Estado administrativo', en el sentido de que la Administración, y no a legislación o la actividad jurisdiccional, es el centro de la actividad estatal. Posteriormente, se ha sostenido que las autoridades administrativas, además de administrar, desarrollan una importante actividad normativa y de solución de 


\subsubsection{Evolução Legislativa ${ }^{218}$}

A lei de organização da Presidência de República e dos Ministérios dispõe expressamente que (i) a política de desenvolvimento da indústria, do comércio e dos serviços e (ii) a propriedade intelectual e transferência de tecnologia são assuntos da área de competência do Ministério do Desenvolvimento, da Indústria e do Comércio Exterior ${ }^{219}$. É relevante o fato da lei citar expressamente a transferência de tecnologia e não somente propriedade intelectual. Reconheceu-se que a regulação da transferência de tecnologia, ainda que afeita a aspectos de propriedade intelectual e com esta guardando maior afinidade, é matéria autônoma, envolvendo outras áreas do conhecimento ${ }^{220}$.

O INPI foi criado em 1958 pela Lei 5.648/70. O Instituto substituiu o Departamento Nacional de Propriedade Industrial, também vinculado ao Ministério da Indústria e do Comércio, mas que não possuía o dinamismo e a flexibilidade desejados para o órgão responsável pela proteção à propriedade industrial no país ${ }^{221}$. Com a lei, destinou-se ao INPI receita própria oriunda dos serviços prestados, instituiu-se publicação própria para divulgação de seus atos, a fim de aliviar o Diário Oficial da União, e atribui-se ao INPI competência específica em relação às operações de transferência de tecnologia. Inicia-se o

conflictos" (CASSESE, Sabino. Las bases del derecho administrativo. Madrid: Instituto Nacional de Administración Pública, 1994, p. 27).

Andrade expõe que: "[...] No entanto, mesmo quando se trate apenas de submissão ao princípio do primado da lei, sua interpretação deve ser precisa, ou seja, diante da outorga de capacidade normativa ao executivo, essa outorga deve ser específica, ou melhor, deve ser feita de forma clara, estabelecendo-lhe o conteúdo a ser regulamentado, seu fim e sua extensão. Dessa forma, o parlamento estabelece os limites dentro dos quais a capacidade normativa será exercida. Logo, o fato de o poder executivo ter capacidade normativa não chega a constituir forma de afronta ao princípio da distribuição dos poderes, pois essa capacidade normativa somente é exercida em virtude de autorização conferida por outro poder, titular nato dessa prerrogativa. É, pois, o próprio poder legislativo que estabelece o quadro no qual será exercida a capacidade normativa conferida à Administração, determinando quando e onde os regulamentos serão editados. Ademais, pode, ainda, o legislativo, com base no princípio do primado da lei, revogar a habilitação conferida, ab-rogar e modificar atos normativos da Administração. Basta, para isso, editar lei sobre a mesma matéria" (ANDRADE, R. E. de. A Capacidade Normativa da Administração Pública. In: (org.). Regulação Pública da Economia no Brasil. Campinas: Edicamp, 2003, p. 93 e ss.).

${ }^{218}$ Não analisaremos neste ponto as atividades e atribuições do órgão encarregado da proteção à propriedade intelectual previamente à criação do INPI. Até a criação do INPI, os contratos de transferência de tecnologia objeto deste trabalho estavam sujeitos a registro na SUMOC (Para uma análise da legislação referente a aspectos cambiais neste contratos, vide Item 4, infra). Conforme Elias e Cassiolato: "Até então, não se percebia a importação de tecnologia como um instrumento de política industrial e tecnológica voltada às necessidades do setor produtivo nacional" (ELIAS, L. A.; CASSIOLATO, J. E. O Balanço de Pagamentos Tecnológicos Brasileiro: Evolução do Controle Governamental e Alguns Indicadores., p. 281).

${ }^{219}$ Lei 10.683/03 e alterações posteriores, art. 27 inc. IX alíneas a) e b), respectivamente.

${ }^{220}$ Referimo-nos ao Capítulo I, Itens $1,2,3$ e 5.

${ }^{221}$ EM 8 de 4/09/1970. 
vetor interpretativo da regulação de transferência de tecnologia sob o viés da propriedade intelectual.

A Lei $5.468 / 70$, art. $2^{\circ}$, dispõe:

O Instituto tem por finalidade principal executar, no âmbito nacional, as normas que regulam a propriedade industrial, tendo em vista a sua função social, econômica, jurídica e técnica.

Parágrafo único. Sem prejuízo de outras atribuições que lhe forem cometidas, o Instituto adotará, com vistas ao desenvolvimento econômico do País, medidas capazes de acelerar e regular a transferência de tecnologia e de estabelecer melhores condições de negociação e utilização de patentes, cabendo-lhe ainda pronunciar-se quanto à conveniência da assinatura, ratificação ou denúncia, de convenções, tratados, convênios, e acordos sobre propriedade industrial. (Nossos grifos).

O Decreto 68.104/71, que regulamenta a Lei 5.648/71, dispôs, ainda, que o INPI deverá criar melhores condições de absorção, adaptação ou desenvolvimento de ciência ou tecnologia, por meio do aproveitamento das informações acumuladas e de ampla divulgação nos setores industriais ou de pesquisa. À Secretaria de Informações e Transferência de Tecnologia $^{222}$ caberia orientar, fiscalizar e fazer executar as atividades de transferência de tecnologia. ${ }^{223}$ Os Decretos que se seguiram, Decreto $77.483 / 76^{224}$ e Decreto 77/91 225 continuavam a dispor sobre a função da autarquia de criar melhores condições de absorção de tecnologia e acelerar a transferência de tecnologia.

A Lei 5.772/71, código da propriedade industrial, fazia remissão expressa ao dispositivo legal de "medidas para a regulação da transferência de tecnologia da lei de criação do INPI" ao estipular a necessidade de averbação dos contratos:

Art. 126. Ficam sujeitos à averbação no Instituto Nacional da Propriedade Industrial, para os efeitos do art. $2^{\circ}$, parágrafo único, da Lei n. 5.648, de 11 de dezembro de 1970 , os atos ou contratos que impliquem transferência de tecnologia.

Consolidou-se, assim, moldura legal fechada e completa para a aplicação da política de transferência de tecnologia pela autarquia.

\footnotetext{
${ }^{222}$ Predecessora da DIRTEC, Diretoria de Transferência de tecnologia e outros Registros do INPI.

${ }^{223}$ Art. $3^{\circ}$ inc. III e art. 19 inc. I.

${ }^{224}$ Art. $2^{\circ}$ inc. I e III; art. 12.

${ }^{225}$ Art. $1^{\circ}$ inc. I e art. 11. À época da edição do decreto o INPI encontrava-se subordinado ao Ministério da Justiça. Em 1992 a autarquia "retornou” ao Ministério da Indústria e Comércio.
} 
Os regulamentos emitidos em seguida pelo INPI dando conta do escopo de sua atuação estreitaram ainda mais os contornos da averbação dos contratos. O Ato Normativo 15/75 da Presidência do INPI definia parâmetros e critérios para a contratação, informando termos e condições obrigatórios e proibidos para os instrumentos. Adicionalmente, estipulava a revisão da conveniência de ser importada determinada tecnologia, "considerando as diretrizes estabelecidas no II PND",226. Em 1978, o Ato Normativo 30/78 limitou o registro de contratos de fornecimento de tecnologia industrial para a indústria automobilística; o Ato Normativo 32/78 tornou a submissão do contrato para consulta previamente ao pedido de averbação obrigatória. ${ }^{227}$

Exercia o INPI verdadeiro dirigismo contratual. ${ }^{228}$ A autarquia aplicava, quando do registro do contrato, critérios de seleção prioritária de tecnologias, comprovação de não existência de tecnologia similar em território nacional, determinava investimentos a serem realizados pela parte brasileira em pesquisa e desenvolvimento próprios para permitir a efetiva substituição da importação da tecnologia ${ }^{229}$. Assim como ocorria à época na regulação

\footnotetext{
${ }^{226}$ AN 15/75, Consideranda. II PND: II Plano Nacional de Desenvolvimento, vide Item 1 supra.

${ }^{227}$ Outros Atos Normativos foram emitidos pelo Presidente do INPI à época, os quais não analisaremos no contexto deste trabalho. Conforme Franco, V. H. De M., ocorre, na realidade, uma integração contratual, há uma concorrência de fontes na formação do contrato: "Não se trata de predeterminação do conteúdo contratual, mas sim de concorrência com fontes na formação do regulamento do contrato, (...) [H]á, na hipótese, uma intervenção direta do Estado na determinação do conteúdo contratual; intervenção que não se apresenta somente como limites externos à atuação privada, mas, como verdadeiros elementos que vão integrar o próprio regulamento estabelecido pelas partes (conteúdo do contrato) (...) ao lado da vontade negocial passa a coexistir a vontade legal, ambas tendentes à determinação do conteúdo. (...) A integração contratual não abrange somente a função de preencher as lacunas do contrato, mediante normas dispositivas (supletivas), mas, ainda, a de determinar-lhe o conteúdo, mediante normas cogentes, cuja incidência não pode ser afastada pela disposição das partes" (FRANCO, V. H. De M. Contratos de Transferência de Tecnologia: Intervenção Estatal e Tutela Legal. Revista de Direito Mercantil, São Paulo, ano VXIII (nova série) 1979(33)).

${ }^{228}$ Conforme Grau, E. o termo "dirigismo contratual” foi cunhado por Josserand, “(...) atividade na qual a ação intervencionista do Estado acaba por impor uma reformulação da teoria ortodoxa dos fundamentos do contrato, levando a uma minimização desta prerrogativa." GRAU, E. A Ordem Econômica na Constituição de 1988 (Interpretação e Crítica). 9. ed. São Paulo: Malheiros, 2004a, p. 95.
}

Conforme o item 4.1.2 do AN 15/75:

"Quando oriunda do exterior, a tecnologia a ser transferida deverá:

a) enquadrar-se nos critérios de seleção prioritária, baseados na natureza do produto ou processo e na sua significação para o desenvolvimento nacional, segundo a política governamental para o setor;

b) corresponder a níveis que não se possam alcançar ou obter no país, apurados através do confronto com a efetiva e disponível capacitação interna para sua execução ou com fontes alternativas já existentes;

c) acarretar, a curto prazo, efetivas vantagens para o progresso do setor, em concordância com os objetivos da política ou planos nacionais em matéria de tecnologia industrial e desenvolvimento;

d) criar condições qualitativas para o produto resultante de sua aplicação, com vistas principalmente à exportação;

e) permitir a substituição de importação do produto, inclusive de insumos e componentes necessários à sua fabricação" (grifos nossos)

${ }^{229}$ Para um delineamento da forma de avaliação do INPI da conveniência e oportunidade da contratação, vide artigo do Diretor de Contratos do INPI à época, Mauro Arruda. ARRUDA, M. La Experiencia Brasileña en la Regulación de la Trasferencia de Tecnologia. Revista del Derecho Industrial, Buenos Aires, Depalma, 1982 (12), p. 499 e ss. 
macroeconômica da economia, o INPI tentava conciliar interesses inconciliáveis em relação à transferência de tecnologia. Ao mesmo tempo em que pretendia estimulá-la (que tinha de vir de fora, pois não existia internamente), criava critérios que afastavam as contratações, por meio de (i) seleção de tecnologias prioritárias, (ii) dirigismo contratual e (iii) aplicação da legislação cambial e fiscal com um viés restritivo. ${ }^{230}{ }_{-}^{231}$

Em 1983, ainda no ápice desta orientação diretiva do Instituto, surge o Ato Normativo da Presidência do INPI 64/83. Com a finalidade de envolver as empresas nacionais em programas de investimento em infra-estrutura tecnológica e em atividades de pesquisa e desenvolvimento, paralelamente à contratação de tecnologia externa, o AN 64/83 condicionou a averbação dos contratos de transferência de tecnologia externa à implementação de programa de investimentos em infra-estrutura tecnológica, seja na própria empresa nacional, seja em institutos de pesquisa. $\mathrm{O}$ montante dos investimentos necessários seria definido em função do valor estimado no contrato de transferência de tecnologia externa. Para empresas de maioria de capital estrangeiro que contratassem com empresa estrangeira de fora do grupo do controle societário $^{232}$, além do compromisso da empresa brasileira de investir localmente, também a contratante estrangeira deveria realizar investimentos em capital de risco equivalente ao que a empresa nacional tivesse de remeter em divisas como pagamento pela tecnologia, ainda antes da respectiva remessa ser efetuada ${ }^{233}$.

Os Atos Normativos 15/75 e 64/83 foram revogados somente em 1991 com a Resolução 22 de 27/02/1991 do Presidente do INPI, regulamentada pela Instrução normativa 1/91. A Resolução trata especificamente da averbação do contrato como forma de promover a efetiva absorção e a capacitação tecnológica da parte receptora da tecnologia, mas retira-lhe o conteúdo de substituição de importações, e regulamenta as cláusulas contratuais de forma muito mais suave do que o Ato Normativo 15/75. Refletia-se, assim, a mudança de estratégia

\footnotetext{
${ }^{230}$ Vide Itens 3 e 4 infra.

${ }^{231}$ Conforme CABANELLAS, G. J. Antitrust and direct regulation of international transfer of technology transactions: a comparison and evaluation, p. 24 e 25, o escopo de atuação das autoridades de registro de contratos de tecnologia na América Latina era concedido de forma tão ampla pelas respectivas legislações que os limites de sua atuação poderiam ser inferidos somente dos precedentes administrativos da própria autoridade ou dos limites intrínsecos da atividade, físicos do seu pessoal e esgotamento das fontes de informação.

${ }^{232}$ A remessa de pagamentos (para licenças de marcas e patentes) entre empresas do mesmo grupo econômico com controle sobre a parte brasileira só veio a ser permitida com o advento da Lei 8.383/91. Fazemos referência ao Item 3 deste Capítulo.

${ }^{233}$ A atuação do Instituto em relação aos contratos de transferência de tecnologia aplicando a política econômica à área foi referendada pela jurisprudência, conforme RE 95.382 em 05/08/1983 (1 $1^{\mathrm{a}}$ Turma do STF). Comentando referida decisão, Silveira, N. entende que havia, à época, excessiva regulamentação que acabava por emperrar a contratação da tecnologia. SILVEIRA, N. INPI - Transferência de Tecnologia - Leis 5.648/70 e 5/772/71 Averbação de contrato no INPI. Revista de Direito Mercantil 1984(54), p. 119.
} 
do Executivo quanto à política industrial e comercial, no contexto de abertura econômica e não mais da política de substituição de importações ${ }^{234}$.

Em 1993 o Ato Normativo 120/93 do Presidente do INPI revoga a Resolução 22/91 estipulando a prevalência da liberdade contratual e limitando a atuação do INPI à informação sobre os limites aplicáveis de acordo com a legislação fiscal e cambial vigente ${ }^{235}$. Tratava-se, pois, de ato regulamentar de inspiração liberal, não obstante a lei ainda determinar a adoção pelo Instituto de "medidas capazes de acelerar e regular a transferência de tecnologia”. À época, a interpretação pelo Presidente do INPI do que seria acelerar e regular a transferência de tecnologia foi a da aplicação da legislação tributária e cambial que restringia os pagamentos contratuais, somente, nos termos da política macroeconômica de estabilização da economia. Dada a demasiada liberdade conferida às operações de transferência de tecnologia, mantendo-se somente o seu vetor fiscal e cambial, chega-se a se questionar, na doutrina, a legalidade da regulamentação. ${ }^{236}$

Com o advento da Lei 9.279/96, ocorre a revogação parcial do art. $2^{\circ}$ da Lei 5.648/70, retirando o conteúdo referente à aceleração e regulação da transferência de tecnologia das atribuições do INPI. Conforme referido art. 240:

O art. $2^{\circ}$ da Lei n. 5.648. de 11 de dezembro de 1970, passa a ter a seguinte redação: 'Art. $2^{\circ} \mathrm{O}$ INPI tem por finalidade principal executar, no âmbito nacional, as normas que regulam a propriedade industrial, tendo em vista a sua função social, econômica, jurídica e técnica, bem como pronunciar-se quanto à conveniência de assinatura, ratificação e denúncia de convenções, tratados, convênios e acordos sobre propriedade industrial.'

Ainda, na mesma Lei 9.279/96 o artigo que dispõe sobre a necessidade do registro do contrato, art. 211, menciona somente a finalidade de produção de efeitos perante terceiros,

\footnotetext{
${ }^{234}$ Política Industrial e de Comércio Exterior - PICE 1990 (Medida Provisória n. 158/90) que promoveu a abertura comercial, expondo a indústria nacional à competição interna e externa.

${ }^{235}$ Consta do Item 4 do AN 120/93:

“(...) $\S 1^{\circ}$ - Não serão objeto de análise ou de exigência por parte do INPI os dispositivos contidos nos atos ou contratos de que trata este Ato Normativo (...) especificamente aqueles que se refiram a preço, condições de pagamento, tipo e condições de transferência de tecnologia, prazos contratuais, limitações de uso, acumulação de objetos contratuais, legislação aplicável, jurisdição competente e demais cláusula.

$\S 2^{\circ}$ - Não poderá, destarte, o INPI recusar averbação com base em alegada violação de legislação repressora de concorrência desleal, legislação "anti-trust" ou relativa a abuso de poder econômico, de proteção ao consumidor e outras, facultada ao INPI a opção de alertar as partes quanto aos aspectos legais pertinentes".

${ }^{236}$ Barbosa entende que referido Ato Normativo é ilegal, pois emitido de forma desvinculada com a legislação que embasa o próprio Ato Normativo, qual seja, a legislação que regulamenta a atuação do INPI nos contratos de transferência de tecnologia (BARBOSA, D. B. Uma Introdução à Propriedade Intelectual, p. 982).
} 
não se referindo a medidas capazes de acelerar e regular a transferência de tecnologia ${ }^{237}$. Nota-se, claramente, uma flexibilização na normatização dos contratos de transferência de tecnologia. A moldura de atuação do INPI torna-se menos definida. Exige maior atenção quanto aos indicadores de cunho viés interpretativo a ser adotado pelo INPI na regulação.

Em 1997 é editado o Ato normativo 135/97 da Presidência do INPI, menos enfático em termos de liberdade contratual do que o Ato normativo 120/93, o qual revogou. O novo Ato Normativo não entra no mérito da análise específica das cláusulas contratuais, estabelece somente que os contratos deverão indicar claramente o objeto, remuneração, prazos de vigência e de execução e demais cláusulas e condições da contratação, deixando em aberto a faculdade do INPI de ingerir sobre o seu conteúdo, mormente com base na legislação envolvida nesses contratos, citada expressamente no início do normativo ${ }^{238}$.

Não obstante a Lei 9.279/96 ter restringido a atuação do INPI, o Decreto 77/91, que regulamentava suas atividades e ainda estava em vigor, continuava a dispor sobre a função de "criar melhores condições de absorção de tecnologia e acelerar a transferência de tecnologia".

Foi somente em 2003 que novo decreto regulamentador das atividades do INPI foi emitido, Decreto 4.636/03. Adaptando-se às novas funções designadas para o INPI na Lei 9.279/96 e mantendo o mesmo conteúdo da lei da propriedade industrial então em vigor, o decreto estipula que caberá ao INPI executar as normas que regulam a propriedade industrial, tendo em vista sua função social, econômica, jurídica e técnica.

Um ano depois, em 2004, novo decreto (Decreto 5.147/04) ${ }^{239}$, promoveu a reestruturação do INPI com base nas linhas gerais da nova política industrial do Governo Federal $^{240}$ e insere novamente em diploma legal as atribuições do INPI especificamente em relação à transferência de tecnologia, desta vez vinculando expressamente sua atuação à política industrial e tecnológica. De fato, foi somente em novembro de 2003 que o país voltou a ter uma política industrial e tecnológica estruturada ${ }^{241}$. Conforme o Anexo I do Decreto:

\footnotetext{
${ }^{237}$ Lei 9.279/96, art. 211: "O INPI fará o registro dos contratos que impliquem transferência de tecnologia, contratos de franquia e similares para produzirem efeitos em relação a terceiros”.

${ }^{238}$ A saber: Lei 4.131/62, Lei 7.646/87, Lei 8.383/91, Lei 8.884/94.

239 “Aprova a Estrutura Regimental e o Quadro Demonstrativo dos Cargos em Comissão e das Funções Gratificadas do Instituto Nacional da Propriedade Industrial - INPI, e dá outras providências”.

${ }^{240}$ EM Interministerial 00178/MP/MDIC de 07/07/2004.

${ }^{241}$ Lançamento da PITCE, parte PPA 2004-2007, vide também Capítulo I, Item 7.1.2.
} 
Anexo I - Estrutura Regimental do Instituto Nacional da Propriedade Industrial Capítulo I - Da Natureza e Finalidade

Art. $1^{\circ}$ O Instituto Nacional da Propriedade Industrial - INPI, autarquia federal criada pela Lei $\mathrm{n}^{\mathrm{o}}$ 5.648, de 11 de dezembro de 1970 e vinculada ao Ministério do Desenvolvimento, Indústria e Comércio Exterior, com sede e foro no Distrito Federal, tem por finalidade principal executar, no âmbito nacional, as normas que regulam a propriedade industrial, tendo em vista a sua função social, econômica, jurídica e técnica, bem como pronunciar-se quanto à conveniência de assinatura, ratificação e denúncia de convenções, tratados, convênios e acordos sobre propriedade industrial, conforme o art. 240 da Lei $\mathrm{n}^{-}$9.279, de 14 de maio de 1996. (...)

Art. 13. À Diretoria de Contratos de Tecnologia e Outros Registros compete:

I - analisar e decidir quanto à averbação de contratos para exploração de patentes, uso de marcas e ao que implique transferência de tecnologia e franquia, na forma da Lei $\mathrm{n}^{-}$9.279, de 1996, de modo alinhado às diretrizes de política industrial e tecnológica aprovadas pelo Governo Federal;(...). (grifos nossos)

A doutrina e a jurisprudência não são pacíficas em relação à atuação do INPI nos contratos de transferência de tecnologia. Há autores e jurisprudência que entendem que com o advento da Lei 9.279/96 e a retirada expressa da previsão de adoção pelo Instituto de medidas capazes de acelerar e regular a transferência de tecnologia de sua lei de criação; o INPI passou a ser mero executor da legislação cambial e tributária relativa a esses contratos e autoridade de registro dos contratos, para fins de produção de efeitos perante terceiros, somente ${ }^{242}$. Outros manifestam-se no sentido de que ainda lhe cabe poder discricionário em termos de regulamentar o interesse público contido nesses contratos, em que pese ter-se retirado da autarquia o poder de avaliar a conveniência e oportunidade da contratação ${ }^{243}$.

Entendemos que ocorreu, sim, flexibilização na moldura legal de regulação dos contratos pelo INPI. A partir desta flexibilização, não é qualquer ato do órgão sobre o qual se poderá alegar função de aceleração de transferência de tecnologia. A amplitude de poderes conferidos para a execução de normas cumpre um propósito. Permite ao intérprete adaptar sua atuação às flutuações da conjuntura econômica, no exercício de sua capacidade normativa de

\footnotetext{
${ }^{242}$ Neste sentido: LEONARDOS, L. Tratamento do Fluxo de Tecnologia Frente à Nova Lei de Propriedade Industrial e ao TRIPS. Revista da ABPI 2000(47), p. 22, culpando pela manutenção da interferência das contratações de transferência de tecnologia alguns setores empresariais prejudicados pela abertura da economia e a burocracia estatal saudosa do intervencionismo dos anos 70 e 80 (p. 15). LABRUNIE, J. A Transferência de Tecnologia ao Exterior. Gazeta Mercantil, Caderno A4 p. 9, 30/10/2007. AMARAL, P. E. Função Social dos Contratos de Transferência de Tecnologia. Revista da ABPI, Rio de Janeiro, 2003(66), p. 40. VIEGAS, J. Dos Contratos de Transferência de Tecnologia sob o Regime da Nova Lei de Propriedade Industrial. Revista da ABPI, Rio de Janeiro, 1998(34), p. 28. Na jurisprudência: Decisão de Apelação em Mandado de Segurança 71138 - 2007.51.01.800906-6 em 28/04/2008 e Decisão em Embargos de Declaração em 25/08/2009 (TRF 2 ${ }^{\mathrm{a}}$ Região).

${ }^{243}$ BARBOSA, D. B. Uma Introdução à Propriedade Intelectual, p. 983. Na jurisprudência: Decisão de Apelação em Mandado de Segurança - 2006.51.01.504157-8 em 04/06/2008 e Decisão em Embargos de Declaração em 31/03/2009 (TRF 2a Região); Decisão de Apelação em Mandado de Segurança 2006.51.01.511670-0 em 21/10/2008 e Decisão em Embargos de Declaração em 17/02/2009 (TRF 2 ${ }^{\mathrm{a}}$ Região).
} 
conjuntura. $^{244}$ Mas exige do intérprete que esteja atento ao cenário econômico e demais vetores interpretativos de sua atuação. A partir do Decreto 5.147/04 a atuação do INPI caminha estritamente calcada na política industrial e tecnológica do Governo Federal. Infelizmente, a Política de Desenvolvimento Produtivo (PDP) lançada pelo Plano Plurianual (PPA) 2008-2011 nada dispõe sobre a importação de tecnologia, conforme analisamos no Capítulo I, Item 7.

Tendo concluído que ao INPI cabe a aplicação ex ante, ainda no registro do contrato, das normas tributárias e cambiais relativas à contratação de transferência de tecnologia, passamos, em seguida, à análise de referidas normas.

\section{Breve Delineamento e Valoração de Aspectos da Legislação Tributária Aplicável aos Contratos de Transferência de Tecnologia e de sua Interpretação pelo INPI ${ }^{245}$}

A imposição de regras que limitem ou permitam maior liberdade no tratamento tributário a ser conferido aos contratos de transferência de tecnologia inegavelmente influencia a decisão de contratar; é claro que a política fiscal pode inibir operações de transferência de tecnologia.

Do ponto de vista do fornecedor, a transferência de tecnologia gera renda, tributada em todo o mundo precipuamente pelo imposto de renda. Já o recipiente da tecnologia tem interesse em que os pagamentos que efetuar sejam dedutíveis como despesa operacional na apuração do lucro real do seu imposto de renda. Tanto do ponto de vista interno quanto externo o imposto de renda é o principal tributo a incidir sobre a transferência de tecnologia ${ }^{246}$

\footnotetext{
${ }^{244}$ Conforme Grau, o exercício da capacidade normativa de conjuntura ocorre: “(...) mediante a edição de normas emanadas do poder executivo, seja da administração centralizada, seja de alguns de seus entes autônomos, [uma dinâmica capacidade normativa], com o que se confere resposta à exigência de produção imediata de normas jurídicas, que as flutuações da conjuntura econômica estão, a todo tempo, a impor" (colchetes nossos) (Enciclopédia Saraiva do Direito, verbete "capacidade normativa de conjuntura").

${ }^{245}$ Denominamos o delineamento a ser percorrido neste Item do Capítulo II de breve, pois ele não tem a intenção de esgotar a análise das operações de transferência de tecnologia sob o prisma do direito tributário. A função deste delineamento é tão somente demonstrar qual tratamento tributário está em vigor para estas operações, sua perspectiva histórica, e como o tratamento desestimula a importação de tecnologia. Não temos a intenção de empreender análise dos fundamentos deste tratamento tributário sob o prisma de sua natureza jurídica ou constitucionalidade, o que fugiria ao objetivo do trabalho. A literatura citada permite o aprofundamento daqueles aspectos tributários não abordados neste trabalho.

${ }^{246}$ LEONARDOS, G. A Tributação da Transferência de Tecnologia, p. 6 e 10; CASSIOLATO, J. E.; ELIAS, L. A. O Balanço de Pagamentos Tecnológicos Brasileiro: Evolução do Controle Governamental e Alguns Indicadores, p. 290.
} 
A política fiscal brasileira a partir da década de trinta (30) até o final dos anos setenta (70) teve como escopo limitar os rendimentos do capital estrangeiro, dando suporte à política de substituição de importações então em vigor. Como exemplo claro aplicado à área de transferência de tecnologia temos a grande diferença de tributação dos pagamentos por transferência de tecnologia entre partes brasileiras e com fornecedor estrangeiro, sendo esta última expressivamente maior.

Certo é que a política fiscal para esses pagamentos sempre esteve estritamente relacionada com a política cambial, andando ambas em conjunto na repressão à distribuição disfarçada de lucros e manobras contábeis que pretendiam burlar a lei então em vigor que restringia a remessa de pagamentos por marcas, patentes e tecnologia entre empresas relacionadas com controle do capital votante (Lei 4.131/62 e 4.506/64) ${ }^{247}$. Para tanto, aumentou-se o escrutínio sobre esses contratos pela atuação do INPI quando de sua averbação.

Com a abertura econômica a partir da década de noventa (90) observa-se mudança radical na política fiscal brasileira, a qual deixa de fundamentar-se precipuamente em ajustes macroeconômicos orientados para a estabilidade, principalmente em função da enorme inflação e dívida externa da década de oitenta $(80)^{248}$. Esta mudança não se refletiu no tratamento fiscal dos pagamentos pela transferência internacional de tecnologia, o qual permaneceu idêntico ao longo das últimas décadas ${ }^{249}$, com exceção da elevação paulatina de sua carga tributária, com a incidência de novos tributos ${ }^{250}$. Na contramão da política fiscal nacional, a tributação incidente sobre esses pagamentos torna a escolha pelo fornecedor estrangeiro e receptor brasileiro destas operações pouco atraente.

Conforme vimos analisando ao longo deste trabalho, referidas operações devem ser incentivadas como parte da estratégia nacional de exortar a transferência de tecnologia

\footnotetext{
${ }^{247}$ Vide Item 4 deste Capítulo e CASSIOLATO, J. E.; ELIAS, L. A. O Balanço de Pagamentos Tecnológicos Brasileiro: Evolução do Controle Governamental e Alguns Indicadores, p. 285 e 291.

${ }^{248}$ MORI, R. Política Fiscal e Desempenho Macroeconômico. In: VASCONCELLOS, R. F. de (coord.). Direito Tributário: Política Fiscal (série GVLaw). Saraiva: São Paulo, 2009, p. 9.

${ }^{249}$ Leonardos, G. entende que "[n]o Brasil, o imposto de renda tem importância notória na geração de receitas fiscais para a União e, indiretamente (através da participação do produto na sua arrecadação), também para os Estados, Distrito Federal e municípios". Assim, há sempre resistência política a qualquer proposta de redução de alíquota ou de aumento de limite de dedutibilidade do imposto (LEONARDOS, G. A Tributação da Transferência de Tecnologia, p. 10).

${ }^{250}$ CIDE em 2000 (Lei 10.168/00 - anteriormente por meio de Medida Provisórias); ISS Importação em 2003 (Lei Complementar 116/03); PIS/COFINS Importação em 2004 (Lei 10.865/04) e IOF em 2008 (Decreto 6.339/08) - Partindo-se do pressuposto da interpretação de transferência de tecnologia com natureza jurídica de serviços, conforme analisamos no item 3.1 infra.
} 
para a difusão tecnológica e promoção do encalço tecnológico do país. Faz-se necessária a alteração do seu tratamento fiscal, favorecendo-as, sem receio quanto à efetividade e realidade das operações, pois que a atual situação da balança de pagamentos do país não o justifica, e elas continuam sujeitas a registro ex ante pelo INPI, que averiguará sua efetividade, usualidade e necessidade, conforme os requisitos de dedutibilidade da legislação tributária ${ }^{251}$.

\subsection{Classificação das Operações de Transferência de Tecnologia pela Legislação Tributária}

De início cabe ressaltar que a classificação no campo do direito tributário das operações de transferência de tecnologia é diferente de sua classificação pelo direito civil e pelo INPI. Dificuldade maior é causada pelo fato de os contratos que o INPI classifica como "transferência de tecnologia" não terem todos o mesmo tratamento tributário. Cada categoria de operação tem um tratamento fiscal diferente. Importa ressaltar que quem determina o que constitui ou não transferência de tecnologia para fins específicos de registro no INPI é a legislação relacionada às atividades do INPI e não a legislação tributária ${ }^{252}$.

Lembramos que o presente trabalho se ocupa da análise das contratações de transferência de tecnologia não patenteada, incluindo-se, nesta categoria, tanto a transmissão de segredo de negócio direta por meio de fórmulas e documentos quanto a transferência indireta de tecnologia, pela prestação de serviços técnicos. ${ }^{253}$ Analisaremos a seguir a legislação tributária aplicável especificamente a elas.

Cumpre ressaltar que, dentro da categoria de prestação de serviços técnicos, o INPI registra contratos relativos à atividade operacional e pré-operacional de uma empresa. Esta última refere-se a serviços de projeto e instalação de linhas de produção, por exemplo. Esta categoria de serviços não fica sujeita à legislação específica em termos de dedutibilidade

\footnotetext{
${ }^{251}$ RIR 99 Art. 299.

${ }^{252}$ Vide Item 2.3 deste Capítulo. Conforme Ato Declaratório (Normativo) 1/00 da Coordenação-Geral do Sistema de Tributação: “(...) III - Para fins do disposto no Item I deste ato, consideram-se contratos de prestação de assistência técnica e de serviços técnicos sem transferência de tecnologia aqueles não sujeitos à averbação ou registro no Instituto nacional da Propriedade Industrial - INPI e Banco Central do Brasil” (grifamos). A doutrina critica a falta de tecnicidade dos termos utilizados pela autoridade tributária no normativo, já que o termo "assistência técnica" tem se firmado justamente como aqueles serviços que implicam transferência de tecnologia. ${ }^{253}$ Vide Capítulo I, Item 2.
} 
e limites de remessa que explicitaremos nos itens infra ${ }^{254}$. A essas operações aplicam-se as disposições gerais da legislação tributária em relação a serviços, as quais, justamente por serem genéricas e não específicas em relação à transferência de tecnologia, não serão analisadas neste trabalho. ${ }^{255}$ Ressaltamos, assim, que o fato do INPI determinar que uma operação consiste em transferência de tecnologia e registrá-la não deve alterar o tratamento tributário conferido a esta operação, efetuado com base na definição de sua natureza jurídica pelo direito civil e comercial. ${ }^{256}$

Com relação à sua caracterização para fins fiscais, a transferência de tecnologia objeto deste trabalho difere das operações que envolvem um licenciamento de direito de propriedade industrial propriamente dito. Pagamentos relacionados à propriedade intelectual geralmente são conhecidos como "royalties", termo de origem na língua inglesa e cuja tradução para o vernáculo seria "regalias". O conceito de royalties consta da legislação do imposto de renda, Lei 4.506/64, art. 22, e refere-se a rendimentos decorrentes de direitos ${ }^{257}$. A transferência de tecnologia pode envolver (i) segredo de negócio protegido pela concorrência desleal e/ou (ii) prestação de serviços, logo, é desprovida de um direito subjacente. Logo, os pagamentos contratuais destas operações não podem ser classificados no rigor técnico como royalties $^{258}$. Entendemos que pagamentos pela transferência de tecnologia têm a natureza jurídica de taxas pela prestação de serviços e não de royalties, ainda que sujeitas a regras específicas em termos de dedutibilidade e remessa em relação às prestações de serviço ordinárias.

A legislação tributária refere-se usualmente ao termo "despesas de assistência técnica, científica, administrativa e semelhantes" ou "importâncias de assistência técnica,

\footnotetext{
${ }^{254}$ Esta legislação aplica limites com base nas vendas liquidas do produto. Se ainda se está na fase préoperacional, não há venda líquida do produto.

${ }^{255}$ Vide RIR/99, art. 299 e 685, II a).

${ }^{256}$ Conforme Código Tributário Nacional (Lei 5.172/66): “Art. 109 - Os princípios gerais do direito privado utilizam-se para pesquisa da definição, do conteúdo e do alcance de seus institutos, conceitos e formas, mas não para definição dos respectivos efeitos tributários."

257 "Art. 22. Serão classificados como "royalties" os rendimentos de qualquer espécie decorrentes do uso, fruição, exploração de direitos, tais como: a) direito de colhêr ou extrair recursos vegetais, inclusive florestais; b) direito de pesquisar e extrair recursos minerais; c) uso ou exploraçâo de invenções, processos e fórmulas de fabricação e de marcas de indústria e comércio; d) exploração de direitos autorais, salvo quando percebidos pelo autor ou criador do bem ou obra" (grifos nossos). A Instrução Normativa da Secretaria da Receita Federal 208/2000 reproduz o conceito no art. 37.

${ }^{258}$ Algumas decisões da Receita Federal reconheceram extraordinariamente o know-how como um direito, tais como, por exemplo, Solução de Consulta da Superintendência Regional da Receita Federal do Brasil (SRRF) $8^{\text {a }}$ Região Fiscal/DISIT 178 de 26/06/2006 sobre capitalização de know-how. Tradicionalmente, porém, a legislação distingue as duas operações (know-how e licença de direitos de marcas e patentes), entendendo o know-how como assistência técnica e serviços - seja em termos de alíquotas do Imposto de Renda aplicáveis, seja em termos de créditos a serem concedidos no pagamento de contribuições.
} 
científica, administrativa e semelhantes"259 para se referir aos pagamentos por contratos de transferência de tecnologia e ao termo "royalties" para se referir aos pagamentos pela licença de uso de marcas e pela licença de exploração de patentes ${ }^{260}$.

Operações internacionais de transferência de tecnologia podem estar sujeitas a Tratado para Evitar a Bitributação, conforme o domicílio do fornecedor de tecnologia. Contrariamente à legislação doméstica, o conceito de royalties na Convenção-Modelo da OCDE (Organização de Cooperação e Desenvolvimento Econômico) abrange o know-how ${ }^{261}$. Excepcionalmente, serviços técnicos também poderão ser abrangidos pelo conceito de royalties se constar do Protocolo à Convenção indicação expressa de que os serviços técnicos devem ser incorporados ao conceito de royalties ${ }^{262}$. As Convenções para Evitar a Bitributação são firmadas bilateralmente pelo Brasil e um outro país. Aplicam-se, portanto, em princípio $^{263}$, a contratos de tecnologia firmados pelo receptor brasileiro com fornecedor

\footnotetext{
${ }^{259}$ Conforme a Instrução Normativa da Secretaria da Receita Federal 252/02, art. 17 II b), assistência técnica é a "assessoria permanente prestada pela cedente de processo ou fórmula secreta à concessionária, mediante técnicos, desenhos, estudos, instruções enviadas ao país e outros serviços semelhantes, os quais possibilitem a efetiva utilização do processo ou fórmula cedido."

${ }^{260}$ Invariavelmente, a falta de tecnicidade da redação legislativa acaba inferir que pagamentos por assistência técnica, científica, administrativa e semelhantes seriam royalties, o que contribui ainda mais para a dificuldade de interpretação da lei. Vide, por exemplo, o caput do art. 12 da Lei 4.131/62 (dispondo sobre royalties por assistência técnica) e, logo em seguida, o seu $\S 3^{\circ}$ (dispondo sobre despesas de assistência técnica).

${ }^{261}$ Art. 12, Item 2 da Convenção dispõe: "O termo "royalties", conforme empregado no presente Artigo, significa pagamentos de qualquer espécie recebidos como remuneração pelo uso, ou pelo direito de uso, de um direito de autor sobre uma obra literária, artística ou científica (inclusive filmes cinematográficos), de qualquer patente, marca de comércio, desenho ou modelo, plano, fórmula ou processo secreto, assim como pelo uso, ou pelo direito de uso, de um equipamento industrial, comercial ou científico, ou por informações relativas à experiência adquirida no setor industrial, comercial ou científico" (grifamos e traduzimos do inglês). Disponível em: <http://www.oecd.org/dataoecd/52/34/1914467.pdf>. Acesso em: 22/01/2010.

${ }^{262}$ Como por exemplo no Decreto 5.576/05 (Convenção Brasil-Israel):

"Protocolo (...) 2. Com referência ao Artigo 12, parágrafo $3^{\circ}$

Fica entendido que a expressão "por informação concernente à experiência industrial, comercial ou científica" mencionada no parágrafo $3^{\circ}$ do Artigo 12 inclui os rendimentos originários da prestação de assistência técnica e de serviços técnicos. (...)" (grifamos). Torres, H. T. considera referida equiparação como ausente de qualquer justificação jurídica, constituindo arbítrio normativo. A equiparação de pagamentos por serviços técnicos a pagamentos por royalties por transferência de tecnologia deve se restringir somente ao âmbito de tais acordos e como hipótese de presunção relativa. TORRES, H. T. Propriedade Industrial e Transferência de Tecnologia no Direito Tributário Brasileiro. Repertório de Jurisprudência IOB, 2004(15), volume I, p. 559.

${ }^{263}$ Utilizamos a expressão "em princípio" porque algumas convenções contém cláusulas que prevêem alteração automática das alíquotas do imposto vigentes, caso entre em vigor Tratado do Brasil com outro país, estipulando alíquota menor.
} 
domiciliado no país que celebrou o tratado. ${ }^{264}$ Tratados para Evitar a Bitributação referem-se usualmente ao imposto sobre a renda, somente ${ }^{265}$.

Desta maneira, a fim de verificar o tratamento tributário concedido aos pagamentos sob determinada operação de transferência de tecnologia é necessário verificarse, primeiro, se há tratado com o país de domicílio do fornecedor e qual a redação do tratado e seu protocolo. Em segundo lugar, é necessário verificar qual a natureza da operação principal e pela qual se cobra sob o contrato.

\subsection{O Foco na Dedutibilidade Fiscal dos Pagamentos Contratuais}

A legislação fiscal aplicável aos pagamentos por transferência de tecnologia foca intensamente a dedutibilidade como despesa operacional pela parte brasileira receptora, instituindo regras específicas para esses pagamentos. Adicionalmente, determina que despesas indedutíveis de pagamentos por transferência de tecnologia deverão ser adicionadas ao valor do lucro real, para fins de apuração do imposto de renda devido em cada exercício financeiro. Há uma equiparação entre o que é indedutível e o lucro distribuído, o que não existe para outras categorias de despesa operacional ${ }^{266}$.

$\mathrm{Na}$ época, visou-se coibir a prática que havia se generalizado de sociedades brasileiras controladas por capitais estrangeiros remeterem para os sócios controladores no exterior parte dos lucros sob a forma de royalties ou assistência técnica. Vários exemplos foram apontados sobre o pagamento de assistência técnica sem a sua efetiva prestação, ou

\footnotetext{
${ }^{264}$ As Convenções para Evitar a Bitributação têm aplicação automática quando internalizadas por Decreto, sobrepondo-se às disposições da legislação doméstica nos casos específicos que regula Conforme art. 98 do Código Tributário Nacional (CTN). Vide Decisões 119/99 e 24/02 da $7^{a}$ Região Fiscal e VASCONCELLOS, R. F.; RIBEIRO, R. P., A Transferência Internacional de Tecnologia e sua Tributação. Revista de Direito Tributário Internacional, São Paulo, 2007(6), p. 145.

${ }^{265}$ Conforme o art. $2^{\circ}$ da Convenção-Modelo da OCDE (VASCONCELLOS, R. F.; RIBEIRO, R. P., A Transferência Internacional de Tecnologia e sua Tributação, p. 166), entendem que os países podem acordar expressamente sobre a inclusão de outros impostos no escopo da convenção. Em 2000, com a introdução da CIDE - Contribuição de Intervenção no Domínio Econômico - sobre referidos pagamentos contratuais, discutiuse amplamente se este tributo seria abrangido pelas alíquotas máximas de imposto sobre a renda previstas no tratado, já que o fato gerador do tributo era o mesmo do fato gerador do imposto sobre a renda. Ocorre, porém, que os contribuintes são distintos, de forma que não se pode praticar a extensão da aplicação também a este tributo.

${ }^{266}$ Portaria 436/58 item e). Lei 4.131/62, Arts. 13 e 43. O que exceder aos limites legais serão tidos como lucros distribuídos, implicando sujeição ao Imposto Suplementar de Renda, se atingidos os seus critérios. Vide: BARBOSA, D. B. A Tributação da Propriedade Industrial e do Comércio de Tecnologia. São Paulo: Revista dos Tribunais e INPI, 1984, p. 188.
} 
para atividades já há muito tempo instaladas no País, que não requeriam importação de tecnologia, ou para produção de bens supérfluos, que não tinham prioridade no esforço de desenvolvimento ${ }^{267}$.

Notamos, assim, que a regulação da dedutibilidade nos contratos de transferência de tecnologia tem função claramente extrafiscal. Como tal, os efeitos atingidos pela norma devem ser monitorados e adaptados, a fim de que a intervenção sobre o domínio econômico se justifique ${ }^{268}$.

\subsubsection{Percentual de Dedutibilidade}

A Lei 3.470/58 introduziu na legislação do imposto de renda requisitos para a dedutibilidade, como despesa operacional, de pagamento a título de "assistência técnica, científica, administrativa ou semelhantes". Conforme o art. 74 da Lei 3.470/58, somente poderiam ser deduzidas as quantias até o limite máximo de $5 \%$ (cinco por cento) da receita bruta do produto fabricado ou vendido. Referidos percentuais seriam estabelecidos e revistos periodicamente pelo Ministro da Fazenda. A intenção era a de que os percentuais fossem ajustados paulatinamente, conforme o grau de essencialidade do produto. Dispunha o artigo, ainda, que a efetividade da despesa seria comprovada mediante a apresentação do contrato, e da verificação de que esses serviços seriam efetivamente prestados.

Os percentuais máximos de dedutibilidade foram estabelecidas pela Portaria 436/58 do Ministro da Fazenda. Referida Portaria divide-se em três categorias principais: (i) indústrias de base, (ii) indústrias de transformação e (iii) royalties pelo uso de marcas de indústria e de comércio. À época ocorria o auge da política de substituição de importações e a indústria automobilística, da construção naval e química (pesada), formavam os "Grupos Executivos" do governo Juscelino Kubitschek. Todos esses setores da indústria constam da Portaria com o máximo percentual de dedutibilidade, $5 \%$ (cinco por cento). Outras indústrias

\footnotetext{
${ }^{267}$ Conforme PEDREIRA, J .L. B. Imposto Sobre a Renda - Pessoas Jurídicas, p. 396: “O pagamento de royalties ou assistência técnica, nessas hipóteses, era meio de diminuir o lucro tributável das sociedades brasileiras e fazer com que a remessa de lucros para o exterior ficasse sujeita apenas à incidência do imposto de $25 \%$ sobre rendimentos de residentes no exterior, sem a prévia incidência do imposto sobre lucro das pessoas jurídicas domiciliadas no país."

${ }^{268}$ Para um estudo aprofundado da extrafiscalidade das normas tributárias, entendidas no seu conceito específico de espécie e não de gênero, ou seja, no seu conceito estrito de normas indutoras, vide: SCHOUERI, L. E. Normas Tributárias Indutoras e Intervenção Econômica. Rio de Janeiro: Forense, 2005.
} 
de transformação não foram tão beneficiadas, tais como produtos alimentares $4 \%$ (quatro por cento), máquinas e aparelhos para uso doméstico, em escritório ou científico 3\% (três por cento), artefatos de borracha e matéria plástica $2 \%$ (dois por cento) e a vala geral de outras indústrias de transformação $1 \%$ (um por cento). Em relação a royalties de marcas, ocorre a limitação a $1 \%$ (um por cento), quando o uso da marca não seja decorrente da utilização de patente, processo ou fórmula de fabricação.

A classificação do ramo de atividade da tecnologia objeto do contrato nos parâmetros da Portaria 436/58 é feita pelo INPI quando do registro do contrato. Na prática, a classificação da tecnologia sob os contratos entre as categorias desta Portaria é extremamente difícil. São vinte e quatro (24) categorias originalmente constantes da Portaria, as quais nem de longe refletem a miríade de áreas de atuação na economia.

Salta aos olhos que os percentuais originalmente estabelecidos em 1958 permaneceram inalterados desde então. A Portaria 436/58 foi alterada poucas vezes para acréscimo de categorias ${ }^{269}$. O próprio instrumento estabelece que "as pessoas jurídicas cujos tipos de produção não figurarem nos grupos indicados poderão solicitar a sua inclusão, mediante requerimento dirigido ao Diretor da Divisão do Imposto de Renda”. Trata-se de um mecanismo que exige a participação dos particulares. Porém, a política industrial do país alterou-se muito desde então, outros setores receberam maior destaque e incentivo, sem serem refletidos por novas inclusões de categorias na Portaria, moto próprio, pelo Governo. Nosso entendimento é que também o INPI deveria fazer sugestões de alteração dos percentuais ao MDIC.

Não encontramos na literatura qualquer indicação da origem do valor de $5 \%$ para o máximo de dedutibilidade. Pagamentos por transferência de tecnologia e royalties internacionalmente são comuns em valores superiores a 5\%, podendo chegar a $10 \%$ ou $30 \%$ ou mais, conforme o ramo de atividade ${ }^{270}$. Cabanellas salienta que a tolerância de um

\footnotetext{
${ }^{269}$ Portaria MF 113/59, Portaria MF 303/59, Portaria MF 151/70, Portaria GB 314/70, Portaria MF 60/94 e esclarecimentos emitidos pelas autoridades fiscais sobre o que estaria abrangido nas categorias existentes da Portaria: ADN/CST 30/1975, ADN/CST 31/75, ADN/CST $37 / 75$.

${ }^{270}$ Conforme palestra na Conferência organizada pela LES Brasil - Licensing Executives Society, "Latin American Innovation Tour", em 05/8/2008 em São Paulo, o Sr. James McCarthy apresentou resultados de pesquisa realizada pela LES USA/Canadá em contratos de licenciamento em biofarmacêuticos, dando conta de que as taxas de royalties variavam principalmente entre $10 \%$ e 17\%, para partes não relacionadas.
} 
percentual de $5 \%$ para pagamentos é uniforme em todas as regulações de transferência de tecnologia editadas na America Latina na década de setenta. ${ }^{271}$

A Lei 4.131/62 conforme alterada pela 4.390/64 estabelece a competência da Superintendência da Moeda e do Crédito (SUMOC) de verificar a assistência técnica prestada, a fim de apurar sua efetividade ${ }^{272}$. Em 1964, a Lei 4.506/64 compila e disciplina os requisitos de dedutibilidade de despesas com assistência técnica. ${ }^{273}$

No ano de 1971, o Parecer Normativo CST $320^{274}$ dispôs sobre a dedutibilidade de pagamentos em contrato de assistência técnica, administrativa e semelhantes condicionando-a à comprovação de que a despesa seja necessária, usual ou normal ao tipo de atividade desenvolvida, ou seja, os requisitos usuais de dedutibilidade de despesas, na forma do que observamos no atual Regulamento do Imposto de Renda - RIR - Decreto 3000/99, art. $299^{275}$.

Em 1979, o Decreto-lei 1.730/79 altera a base de cálculo dos percentuais de dedutibilidade, de percentual sobre a receita bruta, para percentual sobre a receita líquida ${ }^{276}$.

${ }^{271}$ CABANELLAS, G. J. Antitrust and direct regulation of international transfer of technology transactions: a comparison and evaluation, p. 32, nota de rodapé 87.

${ }^{272}$ Art. 10. A Superintendência da Moeda e do Crédito poderá, quando considerar necessário, verificar a assistência técnica, administrativa ou semelhante, prestada a emprêsas estabelecidas no Brasil, que impliquem remessas de divisas para o exterior, tendo em vista apurar a efetividade dessa assistência.

273 “Art. 52. As importâncias pagas a pessoas jurídicas ou naturais domiciliadas no exterior a título de assistência técnica, científica, administrativa ou semelhante, quer fixas quer como percentagens da receita ou do lucro, somente poderão ser deduzidas como despesas operacionais quando satisfizerem aos seguintes requisitos:

a) constarem de contrato por escrito registrado na Superintendência da Moeda e do Crédito;

b) corresponderem a serviços efetivamente prestados à emprêsa através de técnicos, desenhos ou instruções enviados ao país, estudos técnicos realizados no exterior por conta da emprêsa;

c) o montante anual dos pagamentos não exceder ao limite fixado por ato do Ministro da Fazenda, de conformidade com a legislação específica.

Parágrafo único. Não serão dedutíveis as despesas referidas neste artigo quando pagas ou creditadas:

a) pela filial de emprêsa com sede no exterior, em benefício da sua matriz;

b) pela sociedade com sede no Brasil a pessoa domiciliada no exterior que mantenha, direta ou indiretamente, o contrôle de seu capital com direito a voto."

${ }^{274}$ DOU de 05/07/71. Conforme o RIR/99: “Art. 280. A receita líquida de vendas e serviços será a receita bruta diminuída das vendas canceladas, dos descontos concedidos incondicionalmente e dos impostos incidentes sobre vendas (Decreto-Lei 1.598, de 1977, art. 12, § $1^{\circ}$ )"”.

275 “São operacionais as despesas não computadas nos custos, necessárias à atividade da empresa e à manutenção da respectiva fonte produtora (Lei 4.506, de 1964, art. 47).

$\S 1^{\circ}$ São necessárias as despesas pagas ou incorridas para a realização das transações ou operações exigidas pela atividade da empresa (Lei 4.506, de 1964, art. 47, § $1^{\circ}$ ).

$\S 2^{\circ}$ As despesas operacionais admitidas são as usuais ou normais no tipo de transações, operações ou atividades da empresa (Lei 4.506, de 1964, art. 47, § $2^{\circ}$ ).

$\S 3^{\circ} \mathrm{O}$ disposto neste artigo aplica-se também às gratificações pagas aos empregados, seja qual for a designação que tiverem."

276 "Art. $6^{\circ}$ - O limite máximo das deduções, estabelecido no artigo 12 da Lei 4.131, de 3 de setembro de 1962 , será calculado sobre a receita líquida das vendas do produto fabricado ou vendido." 
Esta implica não somente a dedução dos impostos incidentes sobre a venda, como também cancelamentos e descontos concedidos de forma incondicional. Se percentuais limitadores de dedutibilidade são estipulados, faz sentido a limitação também da base de cálculo respectiva, senão estar-se-ia permitindo uma flexibilidade indireta desses percentuais.

No tocante à base de cálculo dos pagamentos, o INPI inquire sobre componentes importados diretamente da parte fornecedora ou de empresa a ela vinculada quando do registro dos contratos. O raciocínio é o de que se partes e componentes inteiros estão sendo importados, em relação especificamente àquelas partes e componentes não haveria transferência de tecnologia, pois a parte receptora não aprende a fabricá-los. Como conseqüência, o Instituto considera que seu valor deve ser excluído da base de cálculo das vendas líquidas.

Trata-se de atuação sem amparo na legislação fiscal (não há previsão de desconto de insumos em nenhuma lei) e baseada em uma premissa econômica de controle das remessas de pagamentos. ${ }^{277}$ Esta premissa não existe mais na realidade atual. Que benefício de absorção e difusão da tecnologia pelo receptor brasileiro trará uma limitação na dedutibilidade pelo receptor brasileiro dos pagamentos que efetua?

Conforme a legislação que regulamenta suas atividades, o INPI deve, sim, avaliar se há transferência de tecnologia no caso concreto. Mas não com a finalidade de limitar pagamentos. A autarquia deveria avaliar se há no caso concreto conteúdo tecnológico sobre a forma de montagem de produtos; poderia chegar à conclusão que a operação principal que desponta no caso concreto não é transferência de tecnologia segundo o conceito do INPI, mas sim de natureza jurídica diversa, como compra e venda de equipamentos ${ }^{278}$. Defendemos, também, que o Instituto efetue análise de aspectos anti-concorrenciais que a vinculação da compra de materiais e insumos ao fornecimento de tecnologia possa gerar, assunto que será analisado no Capítulo III deste trabalho.

\footnotetext{
${ }^{277}$ Referido comportamento estava especificamente previsto no AN 15/75, já revogado (CABANELLAS, G. J. Antitrust and direct regulation of international transfer of technology transactions: a comparison and evaluation, p. 37); entende também que a limitação de insumos na base de cálculo dos pagamento está relacionada a questões de balança de pagamentos, assim como a vedação a cláusulas que limitem as exportações por parte da parte receptora. Barbosa, D. B., in 1984, p. 23, manifesta o entendimento de que estes valores deveriam ser considerados como acrescendo a base de cálculo do limite de dedutibilidade e não excluindo-se dela, conforme interpretação da Lei $4.506 / 64$, art. $23 \S 1^{\circ}$.

${ }^{278}$ Conforme analisamos no Capítulo I, Item 2, a compra de equipamentos industriais é reconhecida como transferência de tecnologia, inclusive pelo TOT Code (Item 6.2), mas não sujeita a registro no INPI.
} 


\subsubsection{Prazo de Dedutibilidade}

A Lei 4.131/62 trouxe a limitação temporal de cinco anos para a dedutibilidade de despesas com assistência técnica, científica, administrativa e semelhantes ${ }^{279}$. Esses cinco anos devem corresponder aos cinco primeiros anos do funcionamento da empresa ou da introdução do processo na produção. Demonstrando-se a necessidade, esse prazo poderá ser prorrogado por cinco anos adicionais, mediante autorização da SUMOC. O prazo inicial para computação dos cinco anos retroage até a data do protocolo do pedido de registro do contrato no INPI, ou data posterior a esse, mas nunca anterior ${ }^{280}$.

Infere-se pelo senso comum que esta limitação tem o intuito de assegurar ser a tecnologia nova para a empresa receptora, a fim de evitar-se o abuso de remessas por tecnologias há longo tempo incorporadas no processo produtivo da empresa nacional. Entendemos que um controle sobre a efetiva novidade da tecnologia para a empresa é correto e corresponde aos interesses que se pretende proteger com a importação de tecnologia para o país. A tecnologia deve ser nova para a empresa receptora, não para o mercado. Daí contar-se o prazo desde a sua introdução no processo produtivo. Porém, a presunção absoluta de que esta novidade somente ocorreria ou estaria presente nos cinco anos iniciais parece-nos errônea.

O INPI é a autoridade que aplica as limitações temporais na dedutibilidade dos pagamentos pela tecnologia, quando do registro do contrato de transferência de tecnologia. É também quem autoriza na prática eventual prorrogação do prazo por cinco anos adicionais ${ }^{281}$. Na posição da autarquia manifestada em 1982, a regra encontra guarida no entendimento do Instituto de que numa média de dois anos as empresas nacionais já teriam absorvido a tecnologia.

\footnotetext{
279 “Art. 12 (...) $\S 3^{\circ}$ As despesas de assistência técnica, científica, administrativa e semelhantes, somente poderão ser deduzidas nos cinco primeiros anos do funcionamento da empresa ou da introdução de processo especial de produção, quando demonstrada sua necessidade, podendo este prazo ser prorrogado até mais cinco anos, por autorização do Conselho da Superintendência do Conselho da Superintendência da Moeda e do Crédito" (grifamos).

${ }^{280}$ Decisão da Coordenação Geral do Sistema de Tributação (COSIT) 9/00: "São dedutíveis as despesas com royalties e assistência técnica, científica, administrativa e semelhantes correspondentes ao período de tramitação do processo de averbação no INPI do contrato respectivo. Esse período, portanto, retroage somente até a data do protocolo do pedido de averbação, sendo vedada a dedução fiscal dessas despesas quando incorridas em período anterior a essa data".

${ }^{281}$ Sobre o registro das operações pelo Banco Central do Brasil, vide Item 4 infra.
} 
Estudos do INPI teriam inferido que os empresários consideram a tecnologia um insumo a ser consumido em um processo de produção e não como um potencial ativo a ser incorporado e aperfeiçoado. A limitação teria, assim, a função de incentivar, na empresa, a investigação e romper o vínculo de dependência com a fornecedora de tecnologia ${ }^{282}$. O fato de uma limitação temporal de dedutibilidade de pagamentos promover a cultura de pesquisa e desenvolvimento internas à empresa é extremamente questionável e não deveria nortear a atuação do órgão.

Não entendemos que a limitação de prazo para pagamentos logre promover mais intensamente a absorção tecnológica pelo receptor brasileiro. Esta limitação de prazo, cumulada com a limitação de valor, acaba por desincentivar as contratações indo na contramão do que deveria ocorrer. ${ }^{283}$

\subsubsection{Concomitância de Pagamentos por Marcas e Transferência de Tecnologia}

A Letra a) Item II da Portaria 436/58 MF estipula que royalties pelo uso de marcas em qualquer ramo de atividade estariam sujeitos ao coeficiente máximo de dedução de um por cento (1\%), quando o uso da marca não for decorrente da utilização de patente, processo ou fórmula de fabricação. Não menciona referido item, portanto, "despesas de assistência técnica, científica, administrativa ou semelhante”. Referidas despesas constam especificamente, adicionalmente a "royalties pelo uso de invenção, processo e fórmulas de fabricação", em outro item da Portaria, Item I.

\footnotetext{
${ }^{282}$ ARRUDA, M. La Experiencia Brasileña en la Regulación de la Trasferencia de Tecnologia, p. 497 e ss.: "Otro punto en la cual la actuación del Instituto influye sobre las condiciones de los contratos, es el relacionado a los plazos de vigência o, más precisamente, al tiempo durante el cual el adquirente efectúa pagos por la tecnologia recibida. Se supone que mientras ocurren esos pagos persiste un flujo de tecnologia del proveedor al adquirente, y que al final de elos cesaría ese flujo, sea que la empresa nacional haya o no haya absorbido la tecnología. En realidad, ocurre algo muy distinto. Conforme a una conocida investigación del MIT (Massachusetts Institute of Technology) las empresas brasileñas absorben la tecnología en un plazo bastante inferior a los 5 años que generalmente reconoce el INPI como plazo de los pagos. Según este trabajo (ver cuadro II) El $78 \%$ de las empresas encuestadas - entre nacionales y extranjeras - absorben la tecnología en plazos inferiores a los dos años". A pesquisa do MIT mencionado é especificada como: Shing Fung y Cassiolato, The international transfer of technology to Brazil through technological elements, M.I.T, maio de 1976.

${ }^{283}$ Cabanellas salienta que nas regulações de transferência de tecnologia da América Latina é comum a limitação do prazo para registro, vinculado a efeitos fiscais e cambiais dos pagamentos contratuais e também como forma de reduzir a possibilidade de limitação do uso da tecnologia pela parte receptora.
} 
Referido assunto não foi regulamentado em nenhum outro diploma legal, o que gera questionamento sobre o que seria um "uso de marca decorrente de um direito de patente".

A argumentação utilizada pelo INPI é a de não se pode deduzir pagamentos concomitantes por marcas e por patentes. Ao fazê-lo, estar-se-ia permitindo pagamentos em duplicidade, pois se baseariam numa mesma base de cálculo (i.e. a venda uma única vez, de um único produto). Estaríamos, na hipótese, diante da utilização de uma mesma base de cálculo para um pagamento comercial, não para um tributo. Não há qualquer óbice legal para tanto. Ademais, parece-nos que se o mesmo produto, ao mesmo tempo em que incorpora uma patente, também tem nele afixada uma marca, realizar-se-ia pagamentos distintos por naturezas diversas, a saber: (i) exploração de patente e (ii) uso de marca, não subsistindo a argumentação. A linha de raciocínio que se depreende desta atuação é, portanto, a de reduzir o máximo possível os pagamentos contratuais e suas remessas ao exterior, notadamente ultrapassada no contexto econômico atual.

O INPI ainda estende arbitrariamente a aplicação desse dispositivo para pagamentos por transferência de tecnologia. Quanto à extensão do dispositivo legal para pagamentos por transferência de tecnologia, ainda que se argumente a existência de imprecisão terminológica na legislação tributária e cambial para pagamentos por transferência de tecnologia, salta aos olhos que, num mesmo diploma, a diferenciação específica para cada item é utilizada ${ }^{284}$. Forçosamente, há de se concluir que no caso de pagamentos de natureza de assistência técnica, não haveria qualquer impedimento de dedutibilidade de royalties de marcas concomitantemente, já que referidos pagamentos não foram expressamente mencionados. Onde o diploma legal não diferencia, não caberia ao intérprete diferenciar.

Referida atuação do INPI foi referendada em $1^{\circ}$ e $2^{\circ}$ grau de jurisdição, de forma errônea na nossa opinião. Utilizou-se o argumento de que o instituto tem legitimidade, por delegação, para verificação de condições de dedutibilidade fiscal e no que se refere às questões tributárias, cambiais e de capital estrangeiro ${ }^{285}$. Mas a atuação do órgão não está embasada em qualquer lei. Ainda que tenha poderes para aplicar a legislação tributária e regular a transferência de tecnologia, referida atuação deve necessariamente estar pautada em

\footnotetext{
${ }^{284}$ Portaria 436/58, letra a) Itens I e II.

${ }^{285}$ Apelação em Mandado de Segurança 2006.51.01.511670-0 TRF (2 ${ }^{\mathrm{a}}$ Região) de 21/10/2008.
} 
diploma legal, que lhe confere a moldura e delineia a regulamentação. Não cabe à autarquia diferenciar categorias de pagamentos onde a legislação não diferenciou.

\subsection{A Atuação do INPI em Relação a Aspectos Tributários dos Contratos de Transferência de Tecnologia}

O INPI sequer existia à época da instituição, pela legislação, dos limites de cinco por cento e de cinco anos para a dedutibilidade dos pagamentos contratuais. Do ponto de vista da legislação que instituiu esses limites, de cunho fiscal e cambial, conforme estudado no Item 1 do presente Capítulo, o motivo delineador foi o de coibir pagamentos de assistência técnica sem a sua efetiva prestação, ou para atividades já há muito tempo instaladas no País, que não requeriam importação de tecnologia, ou, ainda, para produção de bens supérfluos.

Vale ressaltar que as restrições de dedutibilidade impostas por esta legislação aplicam-se a todas as contratações e não somente às contratações entre partes relacionadas, como no caso da legislação de preços de transferência. No caso de partes relacionadas, a legislação, com finalidade precípua extrafiscal e relacionada à balança de pagamentos do país, impõe a adicionalmente a proibição de remessa, conforme analisaremos no item 4 abaixo.

Doutrina e jurisprudência discutem extensiva e exaustivamente se o registro no INPI é condição para a dedutibilidade dos pagamentos contratuais.

A legislação referente à dedutibilidade dos pagamentos sob contratos de transferência de tecnologia não menciona originalmente a necessidade do registro do contrato no INPI para fins de dedutibilidade ${ }^{286}$. A lei de criação do INPI (Lei n. 5.648/70) nada dispõe sobre a dedutibilidade dos pagamentos por transferência de tecnologia. O Código da Propriedade Industrial (Lei 5.772/71), revogado, mencionava nos arts. $29 \S 1^{\circ}$ e $90 \S 1^{\circ}$ que a remuneração nos contratos de licença de patentes e de marcas, respectivamente, deveria ser

\footnotetext{
${ }^{286}$ Assim, por exemplo, o art. 74 da Lei 3.470/58. Referida lei dispõe sobre a necessidade de registro dos contratos de uso de marcas e exploração de patentes com o órgão governamental vinculado a questões de propriedade intelectual, mas não dos contratos de transferência de tecnologia. A Lei 4..131/62, editada em seguida para disciplinar a aplicação do capital estrangeiro no Brasil, repetiu a mesma redação. Em 1964, a Lei 4..390/64 acrescentou, em seu art. 10, a autorização para que a Superintendência da Moeda e do Crédito (SUMOC) possa, quando considerar necessário, verificar a assistência técnica prestada, a fim de apurar sua efetividade. No mesmo ano, a Lei 4.506/64, em seu art. 52, estipulou que as despesas com contratos de transferência de tecnologia que fossem objeto de proibição de remessa ao exterior seriam indedutíveis.
} 
estipulada em harmonia com a legislação vigente e as "normas baixadas pelas autoridades monetárias e cambiais". ${ }^{287}$ Para os contratos de transferência de tecnologia não havia qualquer disposição nesse sentido. ${ }^{288}$

A primeira menção específica na legislação relacionando o registro do contrato de transferência de tecnologia no INPI e normas tributárias ocorre em 1974, por meio de regulamento fiscal. A Instrução Normativa da 5/74 da Secretaria da Receita Federal estipula que é necessário o registro do contrato no INPI para que os pagamentos contratuais sejam dedutíveis como despesa operacional. ${ }^{289} \mathrm{Na}$ mesma linha, também em 1975 é concedido o Parecer Normativo CST 102. ${ }^{290}$

Em 1979, com o Decreto 1.718/79 o INPI recebe delegação de competências para auxiliar a fiscalização dos tributos e prestar informações quando solicitado ${ }^{291}$.

Em lei federal, o requisito de registro no INPI para a dedutibilidade vem indicado na Lei $8.383 / 91^{292}$. Porém, esta regula a situação de pagamentos efetuados especificamente entre empresas pertencentes ao mesmo grupo econômico, remetidos ao exterior. Logo, nesses casos, a necessidade de registro no INPI para a dedutibilidade é inconteste; nos outros casos?

\footnotetext{
${ }^{287}$ Art. 90 § 1: “A remuneração será fixada com observância da legislação vigente e das normas baixadas pelas autoridades monetárias e cambiais."

${ }^{288}$ Também no ano de 1971, o Parecer Normativo CST 320 dispôs sobre a dedutibilidade de pagamentos em contrato de assistência técnica, administrativa e semelhantes condicionando-a à comprovação de que a despesa seja necessária, usual ou normal ao tipo de atividade desenvolvida, ou seja, os requisitos usuais de dedutibilidade de despesas, na forma do que observamos no atual Regulamento do Imposto de Renda - RIR - Decreto 3.000/99, art. 299. Não se observa, ainda, qualquer menção à averbação do contrato no INPI.

289 “(...) I - A dedutibilidade das importâncias pagas ou creditadas pelas pessoas jurídicas, a titulo de alugueis ou royalties (...), bem como a título de remuneração que envolva transferência de tecnologia (assistência técnica, científica, etc.) somente será admitida a partir da averbação do respectivo ato ou contrato no instituto Nacional da Propriedade Industrial (...)"

${ }^{290}$ DOU de $16 / 09 / 75$.

291 “Art $2^{\circ}$ Continuam obrigados a auxiliar a fiscalização dos tributos sob a administração do Ministério da Fazenda, ou, quando solicitados, a prestar informações, os estabelecimentos bancários, inclusive as Caixas Econômicas, os Tabeliães e Oficiais de Registro, o Instituto Nacional da Propriedade Industrial, as Juntas Comerciais ou as repartições e autoridades que as substituírem, as Bolsas de Valores e as empresas corretoras, as Caixas de Assistência, as Associações e Organizações Sindicais, as companhias de seguros, e demais entidades, pessoas ou empresas que possam, por qualquer forma, esclarecer situações de interesse para a mesma físcalização" (grifos nossos).

292 "Art. 50. As despesas referidas na alínea b do parágrafo único do art. 52 e no item 2 da alínea e do parágrafo único do art. 71, da Lei $\mathrm{n}^{\circ} 4.506$, de 30 de novembro de 1964, decorrentes de contratos que, posteriormente a 31 de dezembro de 1991, venham a ser assinados, averbados no Instituto Nacional da Propriedade Industrial (INPI) e registrados no Banco Central do Brasil, passam a ser dedutíveis para fins de apuração do lucro real, observados os limites e condições estabelecidos pela legislação em vigor.

Parágrafo único. A vedação contida no art. 14 da Lei $\mathrm{n}^{\circ} 4.131$, de 3 de setembro de 1962, não se aplica às despesas dedutíveis na forma deste artigo" (grifamos).
} 
A Lei da Propriedade Industrial de 1996 (Lei 9.279/96), ao estabelecer a necessidade de registro dos contratos que impliquem em transferência de tecnologia para fins de produção de efeitos perante terceiros, não faz menção a qualquer norma tributária.

Ao efetuar compilação da legislação aplicável o Regulamento do Imposto de Renda, RIR, Decreto 3.000/99 $9^{293}$, finalmente dispôs no $\S 3^{\circ}$ do art. 355 que a dedutibilidade das importâncias pagas a título de "remuneração que envolva transferência de tecnologia (assistência técnica, científica, administrativa ou semelhantes, projetos ou serviços técnicos especializados)" somente será admitida "a partir da averbação do respectivo ato ou contrato no Instituto Nacional da Propriedade Industrial - INPI, obedecidos o prazo e as condições de averbação e, ainda, as demais prescrições pertinentes, na forma da Lei 9.279/96, de 14 de maio de 1996."

Apesar de refletir expressamente a necessidade de registro no INPI como prérequisito de dedutibilidade, é relevante o fato de que normas hierarquicamente inferiores, tais como decretos e instruções normativas, não poderiam estabelecer validamente a necessidade de registro do contrato no INPI se esse delineamento já não constasse expressamente de norma hierarquicamente superior. Baseada nesta argumentação, parte da doutrina e da jurisprudência entendem que da legislação acima exposta não se extrai o registro do contrato no INPI como condição para a dedutibilidade dos pagamentos contratuais.

Em apelação em mandado de segurança no ano de 1987 decidiu o Tribunal Federal de que a ver na norma que estabelece o registro do contrato no INPI uma précondição para a dedutibilidade fiscal é ir alem do que expressamente previu o legislador. ${ }^{294}$ No mesmo sentido, outro acórdão em 1991, estipulando que a exigência do RIR é ilegal ${ }^{295}$. Na doutrina, Oliveira:

[...] O RIR/99 também exige como condição para a dedutibilidade a prévia averbação do contrato no INPI. Esse dispositivo regulamentar surgiu sem base

\footnotetext{
${ }^{293}$ O RIR/75 dispunha de maneira idêntica sob o art. $177 \S 3^{\circ}$, bem como o RIR/80 e RIR/94.

294 "Incensurável a r. Sentença monocrática que dispôs que 'a simples leitura do disposto pelo art. 126 do Código da Propriedade Industrial permite-nos verificar que, em tal dispositivo, não se cria obrigação alguma de natureza tributária. Nele se exige tão-só para os fins do artigo $2^{\circ}$ da Lei 5.648/70 o registro dos contratos de transferência de tecnologia do INPI. Assim, ver-se em tal norma, art. 126 do CPI, uma norma de natureza tributária, é ir alem do que expressamente previu o legislador', porque as restrições tocantes à dedutibilidade só são cabíveis a empresas domiciliadas no exterior. Normas hierarquicamente inferiores não alcançam disposições do texto hierarquicamente superior."AMS 109.706 - RS - TFR, $5^{\text {a }}$ Turma, em 28/10/1987.

295 "Se o Código da Propriedade Industrial não exige o registro no INPI, a não ser para os efeitos da Lei 5.648/70, do contrato em apreço, é ilegal a exigência de um decreto (RIR/80) no sentido de prever tal registro como requisito para a dedução das despesas no imposto de renda". AC. 89.04.16370-6/SC - DJU Seção II de $06 / 02 / 1991$
} 
legal, sendo que, antes do RIR/99 e de seus precedentes RIR/75, RIR/80 e RIR/94, a exigência era feita pela Instrução Normativa SRF n. 5/74. A falta de base legal suscitou controvérsias e inúmeros processos, até que surgiram o Decreto-Lei . 2433 de 19.05.1988 e a Lei n. 8383, de 30.12.1991.

O RIR/99, como já o faziam RIR/94 e o RIR/80, além da averbação no INPI, acrescentou, como condições para a dedutibilidade, que sejam obedecidos o prazo e as condições da averbação, bem como as prescrições dos arts. 29, 30, 90 e 126 da Lei n. 5772, de 21.12.1971. [...]. ${ }^{296}$ (grifamos)

Nosso entendimento é o de que o registro no INPI é condição para a dedutibilidade dos pagamentos em contratos de transferência de tecnologia. Isso porque para esses contratos, sejam contratos entre nacionais ou entre fornecedor estrangeiro e receptor nacional, somente o registro no INPI torna-os aptos a produzirem efeitos perante terceiros; o Fisco é um terceiro nesse contrato ${ }^{297}$. Assim, verifica, ex ante, quando da contratação, a presença dos requisitos gerais de dedutibilidade para despesas operacionais: prestação efetiva, usual, útil e necessária à atividade da empresa receptora. ${ }^{298}$

No entanto, estritamente do fato do registro no INPI permitir que os pagamentos sejam deduzidos como despesa operacional não se pode derivar uma competência do INPI para aplicar a interpretar a lei tributária.

Conforme o Código Tributário Nacional (Lei 5/172/96), art. $7^{\circ}$ :

A competência tributária é indelegável, salvo atribuição das funções de arrecadar ou fiscalizar tributos, ou de executar leis, serviços, atos ou decisões administrativas em matéria tributária, conferida por uma pessoa jurídica de direito público a outra, nos termos do $\S 3^{\circ}$ do artigo 18 da Constituição. (grifamos)

$\mathrm{O}$ art. $2^{\circ}$ do Decreto 1.718/79 é claro ao atribuir a competência ao INPI de auxiliar na fiscalização da legislação tributária ou de prestar informações. Não houve uma delegação para interpretar as leis em matéria tributária. Assim, a atuação do INPI, quando pautada em

\footnotetext{
${ }^{296}$ OLIVEIRA, R. M. de. Royalties e Assistência Técnica, Científica, Administrativa ou Semelhante. Guia IOB Imposto de Renda Pessoa Jurídica, São Paulo, Thomson IOB, 2008, p. 8. O autor menciona o Decreto-Lei 2.433/88 referente ao incentivo do Programa de Desenvolvimento Tecnológico industrial e Agropecuário (PDTI e PDTA) - norma específica, que determina que a concessão deste incentivo não prejudica a dedução da despesa permitida pela lei em geral, estabelecendo em seu art. $6^{\circ} \S 4^{\circ}$ que a dedução "continuará" condicionada à averbação do contrato nos termos do Código da Propriedade Industrial.

${ }^{297}$ Vide Item 2.4.1.2 deste Capítulo II.

${ }^{298}$ Art. 299 do RIR/99. Neste sentido, HIGUCHI, H. F. H.; HIGUCHI, C. H. Imposto de Renda das Empresas Interpretação e Prática. 34. ed. São Paulo: IR Publicações, 2009, p. 377 - comentando o Acórdão n. 10305.280/83 do $1^{\circ}$ Conselho de Contribuintes, publicado no DOU de 06/02/1984: "Os atos e contratos relativos à transferência de tecnologia, mesmo que os contratantes sejam residentes ou domiciliados no Brasil, estão sujeitos à averbação no INPI, para ensejar a dedutibilidade dos pagamentos feitos. A averbação tem a finalidade de averiguar e, em seguida, comprovar que se trata de assistência técnica real e verdadeira, necessária, usual e normal no tipo de transações, operações ou atividade da empresa que faz os pagamentos e deseja deduzi-los."
} 
sua "delegação para aplicação da legislação tributária" deve pautar-se tão somente nos estritos limites da lei. Caso contrário, estaria realizando interpretação da lei, o que lhe é vedado.

Em concluindo que no caso concreto o INPI não está atuando dentro de sua “delegação para aplicação da legislação tributária”, deve-se analisar se a autarquia está pautada pela função de "executar, no âmbito nacional, as normas que regulam a propriedade industrial, tendo em vista a sua função social, econômica, jurídica e técnica"299 e pela sua prerrogativa de "analisar e decidir quanto à averbação de contratos de modo alinhado às diretrizes de política industrial e tecnológica aprovadas pelo Governo Federal”300

Certo é que a política fiscal para esses pagamentos sempre esteve estritamente relacionada com a política cambial, andando ambas em conjunto na repressão à distribuição disfarçada de lucros e manobras contábeis que pretendiam burlar a lei então em vigor que restringia a remessa de pagamentos por marcas, patentes e tecnologia entre empresas relacionadas com controle do capital votante (Leis 4.131/62 e 4.506/64). Para tanto, aumentou-se, na época o escrutínio sobre esses contratos pela atuação do INPI, já que esta autarquia cuidava de sua averbação.

Faz-se necessária revisão da legislação fiscal, a fim de torná-la mais precisa e de adequá-la ao atual contexto econômico ${ }^{301}$; faz-se necessária a revisão da política aplicada pelo INPI em relação a esta legislação, conforme o contexto econômico atual.

A fim de promover a efetiva transferência de tecnologia e difusão tecnológica, a regulação tributária deve incentivar as operações de transferência de tecnologia internacional; a regulação relativa à transferência de tecnologia dentro da política industrial e tecnológica do país deve focar em outras cláusulas contratuais que não a de pagamentos, conforme analisaremos no Capítulo III.

\footnotetext{
${ }^{299}$ Lei 4.648/70 Art. $2^{\text {o }}$

${ }^{300}$ Decreto 5.147/04, Anexo I, Capítulo I, Art. 13. Vide Item 2.5 supra.

${ }^{301}$ Conforme Barbosa: "O Regime tributário dos royalties é estabelecido, no sistema vigente, (...) interpretado por uma massa de portarias, instruções normativas, atos declaratórios normativos e pareceres normativos. Tem-se levantado uma série de dúvidas sobre a coexistência desta legislação editada em épocas diferentes, e tratando dos mesmos objetos" (BARBOSA, D. B. A Tributação da Propriedade Industrial e do Comércio de Tecnologia, p. 24) (grifamos).
} 


\section{Os Contratos de Transferência de Tecnologia e a Legislação Cambial}

O último vértice do tripé da atual regulação de transferência de tecnologia internacional no Brasil é a legislação cambial. Já adiantamos no Item anterior que ela está intrinsecamente relacionada à legislação tributária, norteando as finalidades daquela.

Em termos cambiais, controla-se o montante da remessa ao exterior dos pagamentos contratuais em contratos de importação de tecnologia, regulando os fluxos de saída de valores do país. Somente contratos entre partes relacionadas têm o fluxo de valores ao exterior limitado pela regulação. Contratos entre partes independentes são registrados, somente, mas não sofrem qualquer limitação de valores.

A transferência e remessa de lucros ao exterior entre subsidiária e matriz ocorrem como um processo natural do investimento estrangeiro. Existe racionalidade em afirmar-se que a concessão de subsídios para o investimento estrangeiro implica transferir ganhos de contribuintes de países menos desenvolvidos para os bolsos de acionistas em países desenvolvidos. Porém, o raciocínio não faz sentido em um ambiente institucional em que esse investimento (i) não é subsidiado, (ii) não há mais impostos sobre a remessa de lucros ao exterior $^{302}$, nem imposto suplementar sobre a renda e (iii) não há desequilíbrio macroeconômico grave na balança de pagamentos do país.

\subsection{Limitação de Remessas entre Empresas do Mesmo Grupo Econômico}

Cabanellas afirma que tradicionalmente as legislações latino-americanas de transferência de tecnologia tendem a impor restrições mais severas a pagamentos entre empresas coligadas, dado o uso destas operações como forma de burlar a legislação cambial e fiscal. ${ }^{303}$ A proibição de remessa de pagamentos contratuais a empresas do mesmo grupo econômico foi inicialmente instituída no Brasil em 1961. Ela se referia a pagamentos entre matriz e filial e matriz e subsidiária. Não abrangia contratos de transferência de tecnologia:

\footnotetext{
${ }^{302}$ Lei $9.249 / 95$.

${ }^{303}$ CABANELLAS, G. J. Antitrust and direct regulation of international transfer of technology transactions: a comparison and evaluation, p. 26 e 27.
} 
Art. 14. Não serão permitidas remessas para pagamentos de "royalties", pelo uso de patentes de invenção e de marcas de indústria ou de comércio, entre filial ou subsidiária de empresa estabelecida no Brasil e sua matriz com sede no exterior ou quando a maioria do capital da empresa no Brasil, pertença ao aos titulares do recebimento dos "royalties" no estrangeiro.

Parágrafo único. Nos casos de que trata este artigo não é permitida a dedução prevista no art. 12 (doze). (grifamos)

Foi somente em 1964 que a Lei 4.506/64 estipulou que os pagamentos sob contratos de transferência de tecnologia entre partes relacionadas passassem a ser também alcançados pela limitação, porém, apenas parcialmente. As remessas entre subsidiária e matriz passaram a ser indedutíveis, independente de estarem ou não dentro dos percentuais de dedutibilidade de $1 \%$ a $5 \%$ conforme o grau de essencialidade da tecnologia. Não havia proibição específica de efetivá-las ${ }^{304}$ :

Art. 52. As importâncias pagas a pessoas jurídicas ou naturais domiciliadas no exterior a título de assistência técnica, científica, administrativa ou semelhante, quer fixas quer como percentagens da receita ou do lucro, sòmente poderão ser deduzidas como despesas operacionais quando satisfizerem aos seguintes requisitos:

(...)

Parágrafo único. Não serão dedutíveis as despesas referidas neste artigo quando pagas ou creditadas:

a) pela filial de emprêsa com sede no exterior, em benefício da sua matriz;

b) pela sociedade com sede no Brasil a pessoa domiciliada no exterior que mantenha, direta ou indiretamente, o contrôle de seu capital com direito a voto. (grifos nossos). Lei 4506/64 (conforme alterada pela Lei 4.506/64).

A definição, especificamente para esta legislação, daquilo que seria considerado "maioria do capital com direito a voto" (ou com qual critério se proibiria a remessa entre subsidiária e matriz) veio no decreto que regulamentou ambas as leis, Decreto 55.762/65. Conforme consta do art. 20:

\footnotetext{
Parágrafo único. Para os efeitos dêste Decreto, considera-se subsidiária de emprêsa estrangeira a pessoa jurídica, estabelecida no País, de cujo capital com direito a voto pelo menos $50 \%$ (cinqüenta por cento) pertença, diretamente ou indiretamente, a emprêsa com sede no exterior. (grifamos)
}

\footnotetext{
${ }^{304}$ Este entendimento não é pacífico, o INPI aplica a mesma proibição de remessa aos pagamentos por transferência de tecnologia ao registrar estes contratos. Corroborando nosso entendimento: MÉLEGA, L. Contrato de Prestação de Assistência Técnica - Sua Averbação junto ao Instituto Nacional da Propriedade Industrial como Condição à Dedutibilidade das Despesas Respectivas para Efeito da Apuração do Lucro Tributável. Revista de Direito Mercantil, 1975(19), p. 61 e ss.
} 
A proibição de dedutibilidade dos valores remetidos da subsidiária à matriz e a proibição de remessa dos valores foi parcialmente revogada em 1991 pela Lei 8.383/91:

Art. 50. As despesas referidas na alínea b do parágrafo único do art. 52 e no item 2 da alínea e do parágrafo único do art. 71, da Lei $\mathbf{n}^{\circ} \mathbf{4 . 5 0 6}$, de 30 de novembro de 1964, decorrentes de contratos que, posteriormente a 31 de dezembro de 1991, venham a ser assinados, averbados no Instituto Nacional da Propriedade Industrial (INPI) e registrados no Banco Central do Brasil, passam a ser dedutíveis para fins de apuração do lucro real, observados os limites e condições estabelecidos pela legislação em vigor.

Parágrafo único. A vedação contida no art. 14 da Lei ${ }^{\circ} 4.131$, de 3 de setembro de 1962, não se aplica às despesas dedutíveis na forma deste artigo. (grifos nossos)

Em relação a remessas entre filial e matriz, permanecem as restrições.

\subsection{A Atuação do INPI em Relação a Aspectos Cambiais dos Contratos de Transferência de Tecnologia}

A regulamentação da necessidade de registro de contrato de transferência de tecnologia no INPI previamente ao registro no Banco Central do Brasil ocorreu por meio do Comunicado Firce (Gerência de Fiscalização e Registro de Capitais Estrangeiros) do Banco Central do Brasil, n. 19 de 16/02/72 $2^{305}$. Antes desse Comunicado, remessas ao exterior sob contrato de transferência de tecnologia eram autorizadas sem o registro no INPI, conforme pode ser depreendido do próprio texto do Comunicado, que condiciona a aprovação dos processos de registro pendentes e dos processos de renovação ao recém instituído registro no

305 “Comunicado Firce n. 19

Remessas para o exterior referentes a marcas e patentes e tecnologia.

Comunicamos que, em virtude do que dispõe a Lei 5772, de 21.12.71, que instituiu o novo Código da Propriedade Industrial, e de conformidade com a decisão do Conselho Monetário Nacional, em sessão de 2.2.72, os atos ou contratos de exploração ou uso de marcas e patentes e de transferência de tecnologia subordinam-se às seguintes normas, relativamente a seu registro no Banco Central (Fiscalização e Registro de Capitais Estrangeiros), para os fins da Lei 4.131, de 3.9.62, modificada pela Lei 4.390, de 29.8.64:

a) o registro está sujeito à apresentação, pelo contratante domiciliado no País, de prova de que o documento foi averbado no Instituto Nacional da Propriedade Industrial, do Ministério da Indústria e do Comércio; (*)

b) o disposto na alínea anterior, aplica-se, também, aos pedidos de registro ainda em exame no Banco Central, bem como às solicitações de prorrogação de registros já efetuados; (**)

c) os Certificados de Registro que estabeleçam prazos indeterminados só amparam remessas para o exterior até 2.8.72, assegurada a seus titulares a faculdade de solicitarem, desde já, a renovação do registro, sempre mediante prova de averbação do contrato junto ao Instituto Nacional da Propriedade Industrial.

Rio de Janeiro, 16 de fevereiro de 1972

Gerência de Fiscalização e Registro de Capitais Estrangeiros (7)

Antonio Radesca

Gerente

(*) Vide Ato normativo n. 15 de 11.9.75.

(**) Vide Carta-Circular FIRCE n. 37 de 28.2.72” (grifos nossos). 
$\mathrm{INPI}^{306}$. Posteriormente, em 1998, foi implementado o registro eletrônico desses contratos no sistema do Banco Central do Brasil, Sisbacen, por meio da Circular 2.816/98 e Carta-Circular 2.795/98, revogadas em 2010 pela Circular 3.491/10, a qual manteve o mesmo sistema de registro.

Não há qualquer redação nos normativos citados no sentido de uma delegação ao INPI de competência para aplicação da legislação cambial relativamente a esses contratos; uma delegação para tanto teria necessariamente de ser expressa. ${ }^{307}$ Não obstante, ao registrar os contratos de transferência de tecnologia o INPI efetivamente interpreta e aplica a legislação cambial. $^{308}$

Ficam em evidência interpretações da legislação cambial pelo INPI limitando os valores de remessas ao exterior em contratos de transferência entre partes relacionadas. ${ }^{309} \mathrm{E}$ também não relacionadas, mas então com base na legislação de repressão ao abuso de poder econômico, por julgar o preço cobrado sob o contrato aviltante. ${ }^{310}$ A jurisprudência afirma o papel desempenhado pelo INPI. ${ }^{311}$

\footnotetext{
${ }^{306}$ Deve-se levar em conta que a primeira lei a instituir a necessidade de registro dos contratos de transferência de tecnologia no INPI foi a Lei 5.772/71, justamente em 1971, um ano antes do Comunicado Firce 19/72. Sobre o assunto dispõe também Gabriel Leonardos, in "Tributação da Transferência de Tecnologia, p. 131.

${ }^{307}$ Viegas, J. entende diversamente; por meio do Comunicado o INPI receberia uma delegação do BACEN para auxiliá-lo nos controles cambiais. VIEGAS, J. Contratos Típicos de Propriedade Industrial: Contratos de Cessão e de Licenciamento de Marcas e Patentes; Licenças Compulsórias. In: DOS SANTOS, M. J. P.; JABUR, W. P. (coord.). Propriedade Intelectual: Contratos de Propriedade Industrial e Novas Tecnologias (série GVLaw). Saraiva: São Paulo, 2007, p. 76.

${ }^{308}$ Apesar de adentrar em muitos aspectos da legislação cambial, o INPI não ousa estipular a moeda de pagamentos aplicável à contratação. Conforme o art. 17 do Decreto 55.762/65, que regulamenta a Lei 4.131/62, a moeda dos pagamentos contratuais deverá ser a do país de domicilio ou sede do beneficiário da remessa, exceções feitas a casos especiais, conforme o interesse nacional. Nos casos em que o INPI verifica haver divergências entre a moeda estipulada no instrumento contratual e o dispositivo legal, o instituto limita-se a incluir uma observação no Certificado de Averbação: "À consideração do Banco Central do Brasil o atendimento ao Artigo 17 do Decreto n. 55.762 de 17/02/65." Entendemos que referida isenção ocorre por uma ausência de interesse da autarquia neste aspecto da contratação, que não possui potencial de regulação dentro de um espectro mais amplo de política industrial de regulação do influxo de tecnologia e de remessa de divisas. Com o advento da Circular 3491/10, fica autorizado o registro em outra moeda, desde que acordado pelas partes. (Circular 3491/10, Titulo 3, Capitulo 3, Seção 2 Subsecão 3 Item 4).

${ }^{309}$ Conforme a Lei 8.383/91, art. 50 § único, haveria somente uma restrição de dedutibilidade, não de remessa.

${ }^{310}$ Vide Apelação em Mandado de Segurança 2006.51.01.504157-8 de 04/06/2008 - TRF (2a Região).

${ }^{311}$ Vide Agravo de Instrumento 2002.04.01.033776-0-PR em 07.11.2002. Tribunal Regional Federal da $4^{\mathrm{a}}$ Região, Quarta Turma. Trata-se de agravo de instrumento contra decisão que indeferiu, nos autos de mandado de segurança, o pedido de liminar para que o Banco Central do Brasil efetuasse a remessa de valor à empresa Somar International Ltd. como sinal em negócio de transferência de tecnologia no valor de U\$

30,000.00 (trinta mil dólares norte-americanos), ou, alternativamente, caso haja norma legal proibindo tal remessa, forneça certidão do porque da negativa. A Turma negou provimento ao agravo, por estarem ausentes os pressupostos autorizativos da concessão da liminar.

A decisão informa, ainda, que: “(...) o fato de supostamente não haver regra proibindo a remessa ao exterior da quantia pretendida não significa que a impetrante esteja dispensada de submeter-se ao procedimento instituído pela Circular 2816 e pela Carta-Circular 2875, dentre eles, a averbação junto ao INPI para possibilitar remessa de numerário relativo à transferência de tecnologia.
} 
Na prática, o Banco Central do Brasil registra os contratos após o INPI. Se os termos de registro do INPI são referendados pelo Banco Central do Brasil, há uma legitimação da interpretação da legislação cambial efetuada pelo Instituto.

Com a instituição de obrigatoriedade do registro do contrato de transferência de tecnologia no INPI em 1971 entendemos o registro adicional pelo Banco Central do Brasil desnecessário. Este fica sem função. Este onera e burocratiza cada remessa de pagamentos ao exterior sob o contrato, que é registrada por meio de um esquema de pagamentos no registro declaratório eletrônico do contrato já existente. Referidas remessas, fundamentadas em contrato de transferência de tecnologia já registrado pelo INPI, deveriam ser efetuadas somente mediante apresentação da documentação pertinente ao banco comercial que efetivará a remessa. Lembramos que qualquer remessa ao exterior está sujeita ao controle geral da balança de pagamentos brasileira. Mediante utilização da rubrica e código corretos quando da remessa, o controle de pagamentos geral do país, efetuado pelo Banco Central do Brasil como parte de suas atribuições não restaria prejudicado.

Cassiolato e Elias interpretam que a flexibilização da legislação cambial de restrição de pagamentos ocorrida nos anos noventa (90) não teve impacto significativo no número de contratos averbados pelo INPI, ressaltando que "o modelo anterior era muito pouco restritivo, de modo que até buscava estimular o licenciamento externo por parte de firmas locais" ${ }^{\prime 312}$; apontam que o canal de transferência internacional de tecnologia entre subsidiárias de empresas multinacionais e a matriz não deveria ser visto como uma forma fácil de construir a capacidade interna de inovação. ${ }^{313}$

Expusemos no o Item 7 do Capítulo I, supra que pagamentos por meio de licenciamento estão geralmente associados à presença de corporações transnacionais nos países em desenvolvimento. Empresas operando em mercados de tecnologia sofisticada tendem a guardar a fonte de sua vantagem competitiva, tornando a tecnologia disponível somente sob termos restritivos, sendo natural que prefiram manter a transferência de

\footnotetext{
Assim, uma vez que a impetrante sequer faz prova da tentativa de averbação do instrumento de fls. 31-45 junto ao INPI, não se mostra possível a concessão da liminar (...)".

312 CASSIOLATO, J. E.; ELIAS, L. A. O Balanço de Pagamentos Tecnológicos Brasileiro: Evolução do Controle Governamental e Alguns Indicadores. In: VIOTTI, E. B.; MACEDO, M. de M. (org.). Indicadores de Ciência, Tecnologia e Inovação no Brasil, p. 308 e 318. O Estudo apresenta vários gráficos quantitativos da atividade de registro de contratos no INPI.

${ }_{313}$ CASSIOLATO, J. E.; EliAS, L. A. O Balanço de Pagamentos Tecnológicos Brasileiro: Evolução do Controle Governamental e Alguns Indicadores, p. 317.
} 
tecnologia dentro de sua rede de subsidiárias. ${ }^{314}$ Ademais, em países em desenvolvimento há relativamente poucas empresas em condições de atuar como receptoras de tecnologia avançadas, em comparação com países desenvolvidos. Assim, grande parte dos pagamentos em taxas de licenciamento ocorre entre empresas do mesmo grupo.

Certamente esse canal de transferência de tecnologia não é uma forma fácil de construir capacidade de inovação. Por meio deste, as conseqüências da transferência de tecnologia serão determinadas pelos objetivos gerais da corporação, os quais certamente não englobam a disseminação da tecnologia para potenciais concorrentes. A simples abertura das portas ao investimento estrangeiro realmente não gerará incremento da base tecnológica local.

Entretanto, se esse é o tipo de investimento estrangeiro direto ao qual o país estiver tendo acesso por parte da transnacional, então se deve estimular o licenciamento. Cumulado com uma política de ancoramento desta tecnologia nas economias domésticas dos países.

Entendemos e acreditamos ter comprovado ao longo deste Capítulo que o modelo de regulação anterior e também aquele ainda em vigor no Brasil é extremamente restritivo e desprovido de coerência de aplicação da regulação quanto aos interesses perseguidos. A pequena liberalização de remessas dentro do que é permitido deduzir não representou grande impacto de liberalização na regulação como um todo. Pinçou-se um pequeno aspecto, que limitava as remessas por marcas e patentes entre empresas relacionadas; os demais aspectos da regulação que analisamos supra e que restringem sobremaneira a contratação?

Contribuindo para esse posicionamento, mas com outra argumentação, Cabanellas afirma que ao se estipular controles cambiais para as remessas de pagamentos ao exterior é preciso que a regulação defina o controle para absolutamente todas as remessas, sob pena de se gerar a burla do controle cambial, já que os agentes econômicos escolherão outros canais de remessa, estruturando suas transações de forma a não incidir no controle. ${ }^{315}$ No Brasil, outras categorias de serviços e de licença de propriedade intelectual - tais como licença de software e de direitos autorais, não foram sujeitas ao mesmo controle cambial estrito conferido às operações de transferência de tecnologia.

\footnotetext{
${ }^{314}$ UNCTAD - United Nations Conference on Trade and Development. Transfer of Technology, p. 90 e ss.

${ }^{315}$ CABANELLAS, G. J. Antitrust and direct regulation of international transfer of technology transactions: a comparison and evaluation. Weinheim; Deerfield Beach, Florida; Basel, Verlag Chemie, 1984, p. 38 e 39.
} 
Os agentes econômicos adaptam-se à regulação e vão encontrando formas de fazer os seus negócios que se adaptem melhor aos seus interesses. A transferência de tecnologia é atividade econômica que pode se revestir de várias formas. ${ }^{316} \mathrm{Se}$ o Estado consegue exercer algum tipo de controle da transferência de tecnologia sob o canal registro no INPI, há de se torná-lo atrativo para os agentes, sob pena de não se conseguir levar a cabo a regulação pretendida.

Não se pode esperar que um pequenino afrouxamento na regulação, dentro de um contexto de liberalização extensa da economia a partir dos anos noventa (90) logre aumentar a escolha dos agentes pelo canal transferência de tecnologia - INPI; cumpre ressaltar que os gráficos do Banco Central do Brasil e do INPI apontam um aumento explosivo nas remessas de pagamentos por serviços técnicos especializados e assistência técnica a partir de $1997,{ }^{317}$ o que fortalece nossa tese de que a prestação de serviços técnicos é atualmente aquela que mais importa para o catch up tecnológico brasileiro e onde se concentram as contratações. ${ }^{318}$

Novamente insistimos na necessidade de coordenação entre todos os órgãos envolvidos na regulação a fim de que se atinjam os seus objetivos. Atualmente há falta de definição dos objetivos perseguidos, ou seja, das linhas-mestras interpretativas da regulação.

\section{Conclusão do Capítulo II}

Sob a perspectiva do fundamento jurídico, a atuação do INPI no registro dos contratos encontra embasamento na evolução da atuação e funções do Estado na esfera do privado. Conforme Grau, como a liberdade de contratar tem a intenção de "viabilizar a realização dos efeitos e virtualidades da propriedade individual dos bens de produção", a atuação do Estado sobre o domínio econômico impacta de maneira "extremamente sensível" o regime jurídico dos $\operatorname{contratos}^{319}$. A conformação das relações contratuais delineia a própria atividade econômica e a atuação do Estado deve fazer com que, com o contrato, se alcance

\footnotetext{
${ }^{316}$ Vide Capítulo I, Item 2.

317 CASSIOLATO, J. E.; EliAS, L. A. O Balanço de Pagamentos Tecnológicos Brasileiro: Evolução do Controle Governamental e Alguns Indicadores, tabela na p. 310 e gráfico na p. 301.

${ }^{318}$ Capítulo 1, Item 2.

${ }^{319}$ GRAU, E. A Ordem Econômica na Constituição de 1988 (Interpretação e Crítica), p. 94 e 95.
} 
não somente os resultados privados almejados pelas partes, mas também o interesse público, consubstanciado nos fins últimos da ordem econômica. ${ }^{320}$

A transferência de tecnologia não é uma área autônoma do direito. Ela é uma atividade econômica e sua regulação envolve diferentes áreas do direito. ${ }^{321} \mathrm{Em}$ nossa análise da regulação dos contratos de transferência de tecnologia no Brasil, empreendemos a tentativa de distinguir, a fim de permitir uma análise mais rigorosa e acadêmica, entre diversas áreas da regulação (i.e cambial, fiscal, propriedade intelectual). Resta claro que a fim de funcionar e cumprir o seu papel toda a regulação deve estar alinhavada e em perfeita harmonia, isto é, sob um único viés interpretativo. Não é o que ocorre. ${ }^{322}$

Faz-se necessária revisão desta legislação a fim de torná-la mais precisa e de adequá-la ao atual contexto econômico ${ }^{323}$; faz-se necessária a revisão da política aplicada pelo INPI em relação a esta legislação. Não nos encontramos mais num processo de substituição de importações. É preciso que a autarquia entenda o seu papel no contexto econômico atual da sociedade brasileira.

Rodrik interpreta a importação de tecnologia como um processo de "autodescobrimento" do produtor nacional, pois ele experimenta com as tecnologias existentes e adapta-a às condições locais. Esse tipo de descoberta é diferente de pesquisa e desenvolvimento. O que se empreende aqui não é um produto novo, mas a descoberta de que

\footnotetext{
${ }^{320}$ GRAU, E. A Ordem Econômica na Constituição de 1988 (Interpretação e Crítica), p. 96, especificamente sobre os contratos de transferência de tecnologia: "De outra parte, inúmeras vezes, também, as condições de validez do contrato e o condicionamento de sua execução dependem ou residem em disposições normativas ou atos administrativos externos à vontade das partes. Mencione-se a título de exemplificação, aqui, os contratos de transferência de tecnologia e análogos, em especial os celebrados com empresas do exterior, sujeitos cumulativamente a aprovação e registro do INPI e Banco Central" (grifos nossos). Conforme RODRIK, D. Industrial Policy for the Twenty-First Century. September 2004. Disponível em: <http://www.ksg.harvard.edu/rodrik>. Acesso em: 18/08/2008, p. 2: "Atualmente temos uma oportunidade histórica de tomar uma posição intermediária entre o intervencionismo estatal e a liberdade de iniciativa das forças de mercado. Enquanto que as forças de mercado e o empreendedorismo individual continuariam a ser valorizados na agenda de política industrial, os governos teriam um papel estratégico de coordenação da esfera produtiva para além da simples garantia dos direitos de propriedade, execução dos contratos e estabilidade macroeconômica."

${ }^{321}$ A própria minuta de TOT Code contém sugestões de questões tributárias, cambiais, concorrenciais, administrativas e de propriedade intelectual a serem aplicadas em uma operação. Vide Capítulo I Item 6.2.

${ }^{322}$ Cassiolato, J. E.; Elias, L. A. entendem que "as dificuldades de ordenação dos vários sistemas de informação derivam da diversidade de objetivos, interesses e motivações dos diferentes agentes que participam da gestão das operações que envolvem transferência de tecnologia" (CASSIOLATO, J. E.; ELIAS, L. A. O Balanço de Pagamentos Tecnológicos Brasileiro: Evolução do Controle Governamental e Alguns Indicadores, p. 318).

${ }^{323}$ Conforme Barbosa: "O Regime tributário dos royalties é estabelecido, no sistema vigente, (...) interpretado por uma massa de portarias, instruções normativas, atos declaratórios normativos e pareceres normativos. Tem-se levantado uma série de dúvidas sobre a coexistência desta legislação editada em épocas diferentes, e tratando dos mesmos objetos" (BARBOSA, D. B. A Tributação da Propriedade Industrial e do Comércio de Tecnologia, p. 24) (grifamos).
} 
um certo produto, já estabelecido no mercado mundial, pode ser produzido localmente a um custo baixo. Esse processo de auto-descobrimento envolve altas taxas de ganhos sociais e de custos privados. ${ }^{324}$ Punir-se o receptor de tecnologia impedindo-o de deduzir os pagamentos contratuais não parece lógico. Muito menos desencorajar essas contratações, com uma intervenção exagerada no delineamento contratual.

É preciso pensar na política industrial como um processo, não como um resultado. Conforme Rodrik, isto envolveria escutar a classe de empresários (sem ser capturado pelos seus interesses). O maior problema pode não ser uma omissão, mas talvez um erro de comissão, ou seja, intervenções mal delineadas que aumentaram o custo do negócio. "Assim como a descoberta de custos existentes requer experimentação empresarial, a descoberta de medidas apropriadas para a reestruturação e superação de gargalos necessita de uma aproximação por acerto e erro ao se formular as políticas." 325

$\mathrm{Na}$ atual conjuntura da economia mundial, a regulação da transferência de tecnologia deve ser retomada como instrumento de inserção e de permanência dos agentes econômicos locais no mercado global, competindo. Entendemos que a nova chave de aplicação e interpretação da regulação da transferência de tecnologia é a que prioriza absorção e difusão de tecnologia e instrumentalização da concorrência pela propriedade intelectual.

O fortalecimento da edição de normativos pelo INPI, pelos Ministérios envolvidos e pelo próprio Presidente da República, cada qual no exercício de sua capacidade normativa de conjuntura, delineando e sinalizando para o particular as diretrizes de registro dos contratos de transferência de tecnologia de forma alinhada à conjuntura econômica então em vigor, é fundamental. Com isto, o Governo logrará obter maior segurança jurídica para os particulares, incentivando as operações de transferência internacional de tecnologia, que deve ser a finalidade da regulação, conforme analisamos no Capítulo I, Item 7.2 supra.

Defendemos, assim, a implementação de instrumento de política industrial que foque na criação de normas técnicas e legais que promovam a importação, transferência e conseqüente difusão tecnológica, baseando-se em aspectos do direito da concorrência e do interesse público, conferindo competências específicas e claras ao INPI quando do registro

\footnotetext{
${ }^{324}$ RODRIK, D. Industrial Policy for the Twenty-First Century, p. 9.

${ }^{325}$ RODRIK, D. Industrial Policy for the Twenty-First Century, p. 18.
} 
dos contratos. O Capítulo III do presente trabalho abordará as sugestões de contorno desta regulação. 


\title{
CAPÍTULO III - A INSTRUMENTALIZAÇÃO DA DIFUSÃO E ABSORÇÃo TECNOLÓGICA POR MEIO DA PROTEÇÃo E ESTÍMULO À CONCORRÊNCIA NO DIREITO DE PROPRIEDADE INTELECTUAL
}

\begin{abstract}
Uma das maiores políticas enfrentadas pelos países em desenvolvimento na era da globalização e liberalização é determinar o quão distante eles podem ir na adoção de estratégias orientadas para o mercado a fim de atrair investimento direto estrangeiro e assegurar o crescimento econômico, ao mesmo tempo considerando a extensão das limitações que precisam ser empregadas a tais estratégias a fim de não trazer danos a suas economias no médio e longo prazos. A transferência de tecnologia é um reflexo micro cósmico desta questão mais abrangente. ${ }^{326}$
\end{abstract}

Apresentaremos o tratamento que poderá ser conferido aos contratos de transferência de tecnologia internacional no Brasil sob a ótica do direito concorrencial, relacionado-o com o tratamento com base no direito de propriedade industrial, sob os vetores da absorção e difusão de tecnologia e da instrumentalização da concorrência, focando-se em cláusulas contratuais.

\section{Direito de Propriedade Intelectual, Direito da Concorrência e a Política Industrial nos Contratos de Transferência de Tecnologia}

\subsection{Interação e jogo de interesses em torno destes três elementos na transferência de tecnologia}

Tanto a propriedade intelectual como o direito da concorrência surgem como respostas políticas aos objetivos perseguidos pela sociedade. Seu embasamento é constitucional, porém sua calibragem é política, determinada pela evolução e situação econômica da sociedade. Tome-se como exemplo a evolução da proteção da propriedade industrial e do direito da concorrência nos diversos países. $\mathrm{Na}$ Alemanha, o direito concorrencial desenvolve-se com base na teoria ordo-liberal, que tem uma aproximação mais flexível em relação à concentração econômica, vis-à-vis os efeitos positivos que é capaz de

\footnotetext{
${ }^{326}$ UNCTAD - United Nations Conference on Trade and Development. Transfer of Technology, p. 21.
} 
gerar. Nos Estados Unidos desponta a Escola de Chicago, com viés ortodoxo. ${ }^{327} \mathrm{Na}$ seara da propriedade intelectual, o primeiro sistema de patentes surge em Veneza em 1474. No século XVI alguns Estados alemães usam o instituto da patente assistematicamente. Em 1623 tem-se a lei de patente britânica (Statute of Monopolies), reformada em 1852. A maior parte dos países industrializados instituiu leis de patente na primeira metade do século $\mathrm{XIX}^{328}$. Ainda assim, substâncias químicas ficaram proibidas de serem patenteadas até bem mais tarde: 1967 na Alemanha Ocidental, 1968 nos países nórdicos, 1976 no Japão, 1978 na Suíça e 1992 na Espanha. Motivados ou não por esse fim, referidas sociedades beneficiaram-se da possibilidade de cópia das invenções, largamente difundida, e que propiciou o alcance tecnológico desses países. ${ }^{329}$

Num contexto de liberalização do comércio mundial, a regulação estatal da contratação internacional de transferência de tecnologia vem ficando menos usual. Nas últimas duas décadas, os governos atentaram para exportações e investimentos estrangeiros, os dois fetiches do Consenso de Washington. Isso porque essas duas frentes supostamente são capazes de gerar efeitos distributivos de tecnologia e aprendizado a outras atividades. ${ }^{330}$

Propor, atualmente, o alcance tecnológico brasileiro com base na cópia de tecnologias, seguindo o modelo adotado por muitos países em diferentes épocas passadas seria um despropósito. Acordos internacionais assinados impõem limites à atuação do país e os compromissos assumidos em relação à proteção à propriedade intelectual é um desses limites. ${ }^{331}$ É preciso analisar caminhos viáveis para as políticas dentro da moldura nacional e internacional existente.

\footnotetext{
${ }^{327}$ Vide na Alemanha: MESTMÄCKER, E. Europäisches Wettbewerbsrecht. München: Beck, 1974; e nos EUA: BORK, R. The Antitrust Paradox - A Policy with the War Itself. New York: The Free Press, 1993. Ainda sobre a evolução do direito antitruste no mundo: SALOMÃO FILHO, C. Direito Concorrencial - As Estruturas. 3. ed. São Paulo: Malheiros, 2007, p. 67 e ss.

${ }^{328}$ Joseph Kohler atribui a revolução industrial inglesa à lei de patentes. No mesmo sentido, Douglas C. North. Vide especificamente: NORTH, D. C. Privatization, Incentives and Economic Performance. 1994. Disponível em: <http://ideas.repec.org/p/wpa/wuwpeh/9411002.html>. Acesso em: 18/02/2010, p. 7.

${ }^{329}$ CHANG, H. Chutando a Escada - A Estratégia do Desenvolvimento em Perspectiva Histórica, p. 147. Para a evolução da proteção à Propriedade Intelectual vide GAMA CERQUEIRA, J. Tratado da Propriedade Industrial. 2. ed. São Paulo: Revista dos Tribunais, 1982.

330 Vide RODRIK, D. Industrial Policy for the Twenty-First Century, p. 31. O autor dispõe que é de conhecimento geral que firmas exportadoras tendem a ser mais produtivas e tecnologicamente mais dinâmicas que firmas que vendem predominantemente no mercado doméstico. São as melhores empresas que podem escolher exportar. Conseqüentemente, subsidiar exportações pode fazer pouco para melhorar a capacidade produtiva e tecnológica local. $\mathrm{O}$ mesmo em relação ao investimento estrangeiro direto. Estudos cuidadosos encontraram pouca evidência sistemática de externalidades tecnológicas ou de outra natureza a partir do investimento estrangeiro direto. Alguns encontraram efeitos negativos.

${ }^{331}$ Conforme UNCTAD - United Nations Conference on Trade and Development. Transfer of Technology, p. 23: “(...) algumas medidas operacionais de países receptores, destinadas a induzir fornecedores estrangeiros a
} 
$\mathrm{Na}$ análise da regulação tende-se a focar no empresário brasileiro que importa a tecnologia como o maior interessado na operação. Nesse sentido, qualquer desvio da autonomia contratual das partes pela regulação é visto como aberração. Aonde o empresário brasileiro aceitou as condições e contratou não cabe ao Estado intervir, pois não haveria hipossuficiência nesse caso. O empresário é experiente o suficiente para saber negociar aquele contrato que pretende concluir.

Entretanto, não temos dúvidas de que o empresariado brasileiro que contrata a importação de tecnologia com empresas independentes geralmente ainda está em posição de maior fragilidade do que o fornecedor estrangeiro. Esta posição deriva da própria posição do país como usual importador de tecnologia, o que provoca uma assimetria. ${ }^{332}$ As corporações internacionais são fortemente influentes na operação tecnológica nacional e internacional. Elas produzem, adquirem, dominam o entendimento e organizam o uso dos insumos tecnológicos para além das fronteiras nacionais. As corporações transnacionais são uma força relevante no delineamento de mercados internacionais de tecnologia, especialmente no lado da demanda. ${ }^{333}{ }^{334}$

Dentro do contexto de conflito tecnológico norte-sul ainda existente, ${ }^{335}$ a harmonização do direito da concorrência e da propriedade intelectual em torno do interesse coletivo concentra-se justamente na administração da intenção dos países detentores da tecnologia de manter o seu monopólio e acesso restrito à tecnologia e o dos países receptores de terem amplo acesso e utilização da tecnologia. ${ }^{336}{ }_{-}^{337}$

adotar uma perspectiva mais ativa em relação à transferência e disseminação de tecnologia poderão não mais serem possíveis de adoção por países que acederam a instrumentos internacionais contendo estas limitações". (nossa versão do inglês).

${ }^{332}$ Conforme SALOMÃO FILHO, C. Direito Concorrencial - As Estruturas, p. 211: "Pelos mesmos motivos a pesquisa tecnológica é importante também para os países em vias de desenvolvimento. Com uma agravante bastante séria: a estrutural - ou talvez possa-se dizer endêmica - ausência de verbas públicas suficientes para o financiamento da pesquisa. Trata-se de uma realidade que contribui para reforçar a dependência tecnológica e econômica em relação aos países desenvolvidos" (grifamos.)

${ }^{333}$ UNCTAD - United Nations Conference on Trade and Development. Transfer of Technology. United Nations Publication, p. 90 e ss.

${ }^{334}$ Conforme Nguyen, T. T.: “(...) a aplicação pelos países em desenvolvimento das leis de concorrência aos direitos de propriedade intelectual poderá afetar os interesses de empresas transnacionais (MNCs). As MNCs (...) frequentemente exercem um lobby em seus países de origem a fim de gerar pressões políticas e econômicas no país hóspede (...)" (NGUYEN, T. T. The CFI's Ruling in Microsoft v. Commission. IIC, vol. 39 5/1002, p. 581 e 582) (nossa versão do inglês).

${ }^{335}$ Vide Capítulo 1, Item 5. Porém, já, ligeiramente mitigado para o Brasil, conforme veremos abaixo.

${ }^{336}$ Conforme PRADO, M. C. A. Contrato Internacional de Transferência de Tecnologia. Porto Alegre: Livraria do Advogado Editora, 1997, p. 66: “Constata-se, em geral, os países 'naturalmente exportadores' de tecnologia, como a França, possuem legislação bastante 'liberal', ou seja, pouco restritiva à autonomia das partes, enquanto os países 'naturalmente importadores' apresentam maior interferência do Estado sobre o conteúdo dos contratos." 
Com o desenvolvimento paulatino de capacidades tecnológicas específicas em alguns países em desenvolvimento, incluindo o Brasil, a posição do país vai se tornando menos extrema no sul, subindo gradualmente ao centro. Isto tem como resultado a necessidade atual de também termos de considerar os agentes econômicos nacionais desenvolvedores de tecnologia na regulação. Aos agentes econômicos nacionais também interessa a proteção da propriedade intelectual para suas invenções utilizadas e transferidas no território nacional e a liberdade na negociação contratual a terceiros de suas tecnologias. Porém, entender que o conflito norte-sul se extinguiu com a liberalização dos mercados é ignorar os diferentes posicionamentos e pressões exercidas pelos países, ainda divididos em blocos de negociação dos desenvolvidos e dos em desenvolvimento, em fóruns internacionais. $^{338}$

Conforme tratamos no Capítulo I, a reserva no TRIPS aos países-membros para a especificação de regras concorrenciais em acordos de licença é concessão efetuada em contrapartida às reivindicações dos países em desenvolvimento no âmbito do TOT Code, que não logrou ser assinado. ${ }^{339} \mathrm{O}$ maior motivo de desacordo em relação ao TOT Code foi a questão do controle sobre práticas comerciais restritivas em acordos de transferência de tecnologia. ${ }^{340}$ Cabanellas atenta que os países industrializados enxergam a regulação da transferência internacional de tecnologia como um assunto de cunho eminentemente concorrencial, enquanto os países receptores de tecnologia têm relutância em substituir sua regulação pelas leis antitruste. A fim de verificar se uma pode efetivamente substituir a outra

\footnotetext{
${ }^{337}$ Neste sentido, a jurisprudência brasileira: Recurso Extraordinário 95.382-5 Rio de Janeiro - STF, Primeira Turma, 05/08/1983 e Apelação em Mandado de Segurança 2006.51.01.511670-0 - Tribunal Regional Federal da $2^{\mathrm{a}}$ Região, 21/10/2008.

${ }^{338}$ Estudo da participação das importações e exportações no mercado brasileiro publicado no Jornal Valor Econômico revela que: "Em 2009, a participação das importações no mercado interno do país teve queda. O coeficiente de importação, que mede a representatividade dos importados no consumo interno, caiu de $20,9 \%$ em 2008 para 19, $2 \%$ no ano passado.

O levantamento, feito pela Federação das Indústrias do Estado de São Paulo (Fiesp), mostra ainda que a queda de participação ficou mais concentrada em bens de capital e bens intermediários. [...]Entre os setores em que as importações perderam espaço no consumo interno está o de aeronaves, ferrovias e embarcações. [...]

Segundo relatório da Fiesp, os setores industriais que mais agregam valor são os que têm sofrido maior queda nas receitas com exportação. O setor de veículos e autopeças, por exemplo, viu seu coeficiente de exportação cair de 15, 8\% em 2008 para 10\% em 2009. O setor de máquinas e equipamentos teve queda de 6, 3 pontos percentuais no mesmo período" (Peso de bens de capital importados no mercado brasileiro caiu para 30, 9\%. Jornal Valor Econômico, edição de 03/03/2010 (grifamos)).

${ }^{339}$ ULLRICH, H. Expansionist Intellectual Property Protection and Reductionist Competition Rules: a TRIPS Perspective, p. 730: "Esta reserva a favor da soberania da política de concorrência dos Membros representa concessão feita pelos países industrializados em resposta a um esforço anterior dos países em desenvolvimento de editar um Código de Conduta para a Transferência de Tecnologia" (nossa versão do inglês).

${ }^{340}$ UNCTAD - United Nations Conference on Trade and Development. Transfer of Technology., p. 70.
} 
é preciso analisar se as metas atualmente perseguidas pelos países receptores conseguirão ser atingidas somente com uma regulação concorrencial. ${ }^{341}$

As Diretrizes OCDE para Empresas Multinacionais - "OECD Guidelines for Multinational Enterprises" editadas em 2000 cuidam da matéria de forma ligeiramente diferente da proposta exclusivamente concorrencial. Consta no Capítulo de Ciência e Tecnologia o compromisso das empresas multinacionais de:

Ao atribuírem licenças para utilização dos direitos de propriedade intelectual, ou ao transferirem tecnologia de qualquer outra maneira, fazê-lo em termos e condições razoáveis, de modo a contribuírem para as perspectivas de desenvolvimento do país hóspede a longo prazo. ${ }^{342}$

Apesar de ambígua quanto ao seu significado preciso, esta formulação sugere que preocupações em torno do desenvolvimento podem ser relevantes para determinar se uma prática é razoável ou não. ${ }^{343}$ Ainda, nos comentários às referidas Diretrizes OCDE para Empresas Multinacionais estipula-se que as empresas:

[...] devem considerar como poderão melhorar a capacidade de inovação de suas empresas estrangeiras afiliadas e sub-contratantes e adicionar valor à infra-estrutura científica e tecnológica local, e como poderão contribuir de forma útil para a formulação de políticas pelo governo do país hóspede que conduzam ao desenvolvimento de sistemas de inovação dinâmicos. ${ }^{344}$

É fato que o TRIPS e outros tratados internacionais deixam espaço para a atuação do direito concorrencial nacional e da política industrial dos países em desenvolvimento em termos de transferência de tecnologia - com a finalidade de promover metas econômicas e sociais. É preciso tirar o máximo proveito destas flexibilidades.

No jogo internacional de interesses, começam a despontar acordos bilaterais de investimento que, além de impor padrões mais elevados à proteção da propriedade intelectual,

\footnotetext{
341 Vide CABANELLAS, G. J. Antitrust and direct regulation of international transfer of technology transactions: a comparison and evaluation, p. 12 e 13, e BARBOSA, D. B. Uma Introdução à Propriedade Intelectual, p. 154.

${ }^{342}$ UNCTAD - United Nations Conference on Trade and Development. Set of Multilaterally Agreed Equitable Principles and Rules for the Control of Restrictive Business Practices, art. VIII.4. Disponível em: <http://www.fazenda.gov.br/sain/pcnmulti/diretrizes.asp\#concorrencia>. Acesso em: 19/02/2010.

${ }^{343}$ UNCTAD - United Nations Conference on Trade and Development. Transfer of Technology, p. 78.

${ }^{344}$ UNCTAD - United Nations Conference on Trade and Development, p. 79.
} 
também impõem restrições ao delineamento da política industrial no país receptor de tecnologia. ${ }^{345}$ Conforme relatado pela UNCTAD: ${ }^{346}$

[...] Acordos de Investimento Bilaterais concluídos pelos Estados Unidos e, mais recentemente, pelo Canadá, contém cláusula que proíbe o estabelecimento de exigências de performance, incluindo exigências gerais de transferência de tecnologia, mas que toleram referidas exigências desde que impostas por Tribunais judiciais, administrativos ou autoridades da área da concorrência da parte do país hóspede a fim de remediar uma alegada violação das leis da concorrência. ${ }^{347}$

O Brasil não aderiu a qualquer tratado bilateral que imponha restrições específicas à sua política industrial em relação à transferência de tecnologia, nos moldes acima reportados.

Conforme Rodrik, a política industrial não desapareceu. Na maioria dos países, o desafio não é reinstituí-la, mas reempregar a máquina que já está alocada de forma mais produtiva. Muitos países em desenvolvimento continuaram a manter políticas industriais de diferentes tipos, algumas são vestígios das políticas de substituição de importações do passado, outras são respostas à escassez percebida nas políticas existentes. ${ }^{348}$

A regulação da transferência de tecnologia como parte da política industrial deve nortear-se pelo interesse coletivo. Esse não é o resultado da somatória dos interesses privados; não é o interesse da parte brasileira ou do demandante da tecnologia. Interesse coletivo deve ser entendido como o interesse da coletividade, de todos. ${ }^{349}$ Entendemos que à sociedade brasileira, à coletividade, interessa promover o alcanço tecnológico brasileiro e a inserção do país nas trocas comerciais internacionais em relação de melhor igualdade.

A tendência atual do tratamento da transferência de tecnologia importada aponta para duas vertentes: (i) regulatória - controle da condição na qual a propriedade intelectual é protegida e a tecnologia explorada e (ii) de mercado - foca na liberdade na contratação da

\footnotetext{
${ }^{345}$ Sobre a tentativa dos países desenvolvidos de imporem níveis superiores de proteção aos direitos de propriedade intelectual vide Capítulo I Item 6.3.

${ }^{346}$ UNCTAD - United Nations Conference on Trade and Development. Transfer of Technology, p. 79.

347 Artigo V(2) (e) do BIT Canadá/Filipinas de 1995 e Artigo VI (e) do Acordo Modelo de BIT dos EUA de 1994. Cláusula semelhante também consta do Tratado NAFTA, art. 1106 (1) (f).

${ }^{348} \mathrm{O}$ autor interpreta que a maioria das atuais políticas tomam como presumido que as externalidades estão na exportação e investimento direto estrangeiro e são formuladas em termos setoriais. A arquitetura institucional é raramente adequada para se engajar no processo de descobrimento de necessidades e interação entre os setores públicos e privados. Em alguns países, supõe-se inclusive que menos política industrial, melhor direcionada, teria um efeito melhor (RODRIK, D. Industrial Policy for the Twenty-First Century, p. 31 e ss.).

${ }^{349}$ Vide SALOMÃO FILHO, C. Regulação e Desenvolvimento, p. 8.
} 
transferência de tecnologia para que os detentores de tecnologia possam explorar seus direitos na maior extensão possível. Entendemos que as duas correntes não são excludentes. É possível para um país receptor de tecnologia adotar uma solução híbrida - que equilibre ambas as alternativas - desde que a moldura nacional e internacional em que está inserido o permita. ${ }^{350}$ É esta a posição que defendemos para o Brasil.

Conforme veremos no Item 4.3.1 infra, é possível identificar quatro modelos diferentes já sendo adotados por países em desenvolvimento, que trabalham com a lógica regulatória e a de mercado de formas diferentes: (i) modelo liberal (imunidade absoluta da propriedade intelectual para a aplicação das regras concorrenciais); (ii) modelo de proibição (regulatório puro); (iii) modelo da regra da razão simples (práticas anti-competitivas são analisadas caso a caso) e (iv) modelo híbrido.

Propomos nesse trabalho um modelo híbrido de verificação das cláusulas restritivas em contratos de transferência de tecnologia, baseado em uma política industrial que atente especificamente para a importação de tecnologia como elemento-chave no processo de inovação e desenvolvimento tecnológico nacional. Ela terá como base a coordenação entre o direito de propriedade industrial e o direito da concorrência em torno das contratações, sob o vetor do interesse coletivo.

\subsection{A intersecção entre o direito concorrencial e o direito de propriedade intelectual.}

A proteção à propriedade intelectual tem um forte componente concorrencial. Conforme exposto por Barbosa:

[A] tutela jurídica da concorrência tem sua dimensão de direito privado, que vem sendo historicamente o objeto do segmento da propriedade intelectual denominado concorrência desleal e, na proteção do fundo de comércio ou do aviamento, pelo Direito Comercial; tem sua parcela de direito público, seja na regulação do próprio Estado, seja na tutela geral do espaço concorrencial, esta objeto do chamado Direito de Defesa da Concorrência, ou Direito Antitruste. ${ }^{351}$

\footnotetext{
${ }^{350}$ Vale ressaltar que o relatório UNCTAD salienta que mesmo dentro da aproximação com base no mercado o país receptor de tecnologia possui discrição, na medida em que pode adotar um toque pesado ou leve na sua regulamentação de possíveis efeitos anti-competitivos das práticas restritivas adotadas em operações de transferência de tecnologia. UNCTAD - United Nations Conference on Trade and Development. Transfer of Technology, p. 83.

${ }^{351}$ BARBOSA, D. B. Uma Introdução à Propriedade Intelectual, p. 271.
} 
A primeira acepção da concorrência, concorrência desleal, visa tutelar atuações dos concorrentes contrárias aos ditames da deontologia profissional. Assim, não é a lei que define os limites da concorrência leal, mas as práticas dos demais concorrentes, conforme os costumes usuais do ramo, local, época, é que vão explicitar o que é lícito ou não. Seu delineamento pertence à seara da propriedade industrial. ${ }^{\mathbf{3 5 2}}$

A segunda acepção da concorrência é a que visa a proteger a estrutura do mercado. Não há, aqui, foco na regulação do comportamento dos agentes, mas na própria garantia de existência de determinadas liberdades. Ocupa-se esta acepção de concorrência da conciliação dos princípios constitucionais da livre concorrência e da livre iniciativa e de outros, ainda, com a finalidade de assegurar a todos existência digna segundo os ditames da justiça social. ${ }^{353}$ Dessa forma, a concorrência não é um fim em si mesma. ${ }^{354}$ Nesta última faceta da tutela da concorrência, certas práticas e comportamentos são também relevantes

\footnotetext{
${ }^{352}$ Vide Capítulo I Item 3 supra. A Lei 9.279/96 expõe lista exemplificativa de atos de concorrência desleal em seus Arts. 195 e ss. Salomão Filho, C. entende que as condutas de concorrência desleal formam inegavelmente parte do moderno direito antitruste. Assim, expõe que na Alemanha "[o] direito concorrencial nasce com regras que protegem exclusivamente a lealdade de competição (UWG). Não há qualquer preocupação com a existência da concorrência em si, mas apenas com a forma (leal) do seu exercício. Não há qualquer preocupação com a formação incipiente dos monopólios e cartéis, até porque, inicialmente, os monopólios não são considerados economicamente negativos" (SALOMÃO FILHO, C. Direito Concorrencial - As Estruturas, p. 75 e ss.). Mas também expõe que "[...] não há dúvida de que o direito antitruste só assume seu aspecto publicista com a legislação antimonopólio" (SALOMÃO FILHO, C. Direito Concorrencial - As Condutas. São Paulo: Malheiros, 2003, p. 14).

O autor interpreta, ainda, conter o art. 20 Inc. I da Lei 8.884/94 dispositivos reguladores da concorrência desleal e informa que a intenção de tais tipos de ilícitos é a proteção institucional do sistema concorrencial, a existência da concorrência. Porém, esclarece que o inciso I da Lei 8.884/94 deve ser interpretado sempre em conjunto com o Inciso II, sendo o Inciso I a explicitação da hipótese do inciso II (SALOMÃO FILHO, C. Direito Concorrencial - As Condutas, p. 104 e p. 121 e ss.). Não concordamos com esta interpretação, justamente por entender que a Lei 8.884/94 tem finalidade publicística. A proteção à concorrência desleal é desprovida de aspectos publicísticos, por ser a definição de ilícito auferida na prática, da interação entre os agentes. Colocar o acento da interpretação do inciso I do art. 21 da Lei 8.884/94 sobre a limitação à concorrência, e não ao concorrente, faz com que o Inciso I perca a característica de definidor de concorrência desleal que o autor pretendia lhe conferir.

${ }^{353} \mathrm{O}$ caráter instrumental da proteção à concorrência é o de reprimir o abuso do poder econômico que vise à dominação dos mercados e à eliminação da concorrência, em atenção ao princípio da livre concorrência; reprimir o aumento arbitrário dos lucros em atenção ao princípio de defesa do consumidor. Quanto à justiça social, Salomão Filho entende que: "O grande valor da menção ao objetivo da justiça social não é, portanto, a sua utilização como parâmetro oposto à livre iniciativa, mas sim a afirmação da necessidade de existência de políticas sociais (que compreendem obviamente o desempenho do serviço público no sentido da promoção da justiça social) tendentes a eliminá-la. Relativamente à intervenção do Estado no domínio econômico, regulando ou exercendo atividade empresarial, o valor da menção à necessidade de perseguir a justiça social é orientar a intervenção do Estado na economia no sentido de corrigir as imperfeições do sistema concorrencial, e não eliminar ou substituir este último (...)" (SALOMÃO FILHO, C. Direito Concorrencial - As Estruturas, p. 208).

${ }^{354}$ Constituição Federal, art. 1 inc. IV e 170 caput e inciso IV. Livre iniciativa e livre concorrência são corolários de liberdades individuais, expressando-se num contexto de sociedade. Conforme SEN, A. Development as Freedom. Oxford: Oxford University Press, 1999, p. 297: "Uma variedade de instituições sociais - relacionadas à operação dos mercados, administrações, legislaturas, partidos políticos, organizações não-governamentais, o judiciário, a mídia e a comunidade em geral - contribuem para o processo de desenvolvimento precisamente por meio de seus efeitos em elevar e sustentar as liberdades individuais" (nossa versão do inglês).
} 
como índices de excesso de poder (ainda que nem sempre abuso); mas é a objetividade do espaço concorrencial, e não a culpa ou qualquer outro desvio de comportamento dos agentes, que é o objeto primordial da tutela.

O direito de propriedade intelectual é concedido a um determinado agente do mercado. Esse direito em si exclui outros de usar, fazer, vender ou reproduzir e distribuir obras protegidas ou objetos corporificando direitos de propriedade intelectual durante um determinado período estatutário.

Como decorrência da natureza do direito de propriedade intelectual, ele per se implica, desde sua existência, em um monopólio legal. Porém, monopólio no sentido de exclusividade (e possibilidade de exclusão de terceiros de uso) do direito protegido - não no sentido econômico utilizado pelo direito concorrencial. ${ }^{355}$ Assim, restrições de uso são

${ }^{355}$ Conforme BASSO, M. Análise dos Direitos de Propriedade Intelectual sob a Perspectiva do Direito Antitruste: Especial Referência às Marcas. Revista do IBRAC 2009(1), p. 84: "O requisito da unicidade conferido pelos direitos de propriedade intelectual não tem nenhuma correlação com a unicidade suficiente para conferir ao seu titular monopólio ou poder de mercado. Qualquer presunção, contra ou a favor, de relacionar poder de mercado com os requisitos de propriedade intelectual é economicamente irracional. À luz da lógica do sistema econômico, a única conclusão que se pode chegar é a de que as leis de propriedade intelectual nunca, sob qualquer circunstância, conferem ao titular do direito de propriedade intelectual qualquer poder de mercado. Não existe qualquer ligação entre a unicidade (condição da exclusividade) que justifica os direitos de propriedade intelectual e o mercado".

Ascarelli também atentava para esta diferenciação: "O direito absoluto à utilização da criação intelectual tutela, havíamos notado, a probabilidade de vantagem conseguida por meio da utilização da criação mesma; não a conseguida por meio de determinado gênero de atividade, obstando a outro o exercício deste gênero de atividade; não constitui um direito de monopólio se o termo vem utilizado em seu significado jurídico corrente e não - como ocorre também na doutrina americana - como equivalente a direitos de exclusividade (que poderia então aplicar-se também à propriedade de coisas materiais) em seu sentido econômico. No sentido econômico na realidade (e isto tendo em consideração a formação de preços) a preclusão derivada do direito exclusivo sobre criações intelectuais quase sempre introduz um elemento monopolístico, ainda que, como recordamos, no âmbito das invenções e dos modelos, cada nova criação é, então, um fator de superação do monopólio econômico que possam preexistir e podem por isso reconhecer - como forma de promoção de novas invenções - uma função antimonopolística à disciplina.. monopolística dos brevês e invenção e modelos [...]" (ASCARELLI, T. Teoria della concorrenza e dei beni immateriali. Milano: Giuffrè, 1956, p. 214 e 215) (nossa versão do italiano).

É importante lembrar a diferenciação entre poder de mercado e poder de monopólio. Poder de mercado é comumente definido como a habilidade do vendedor de manter preços de forma lucrativa acima dos padrões de concorrência por um período significativo de tempo (neste sentido: US DoJ and FTC Horizontal Merger Guidelines - www.usdoj.gov/atr). Para provar poder de mercado, os participantes devem definir mercado relevante, demonstrar que a parte tem uma participação dominante deste mercado e demonstrar a existência de barreiras significativas à entrada e que os atuais concorrentes não têm condições de aumentar sua participação a curto prazo. O reconhecimento de um direito de propriedade intelectual, se chegar a tanto - isto dependerá da inovatividade e adequação aos anseios dos consumidores do produto - parece ter potencial de cumprir somente com a primeira parte. As questões em torno de mercado relevante, barreiras à entrada, e situação dos atuais concorrentes estão fora da esfera da propriedade intelectual. O poder de monopólio é definido como o poder de controlar preços ou excluir concorrência em um mercado relevante ou o poder de forçar um comprador a fazer algo que ele/ela não fariam em um mercado competitivo. O poder de mercado em si não é determinante de um poder de monopólio. O poder de monopólio pode ser entendido como um grau significativo de poder de mercado. Entendemos que o direito conferido pela propriedade intelectual autoriza a excluir competidores com relação ao produto, processo ou obra em questão, mas o titular ou aquele que exerce este direito ainda está 
necessárias para que se atinja o objetivo mesmo da proteção pelo direito da propriedade intelectual.

Reforçando a argumentação, é preciso atentar para o fato de que a informação somente se torna um bem econômico na medida em que é reconhecida como propriedade intelectual pelo direito. É preciso cuidado ao equiparar-se a propriedade intelectual às formas usuais de propriedade reconhecidas pelo direito. ${ }^{356} \mathrm{E}$ ao aplicar-se a teoria econômica aos direitos de propriedade intelectual. ${ }^{357}$

A propriedade intelectual deve ser respeitada pelo direito concorrencial como parte integrante do ordenamento jurídico. ${ }^{358}$ Diversas teorias e aproximações jurisprudenciais existem quanto à intersecção de ambos os ramos do direito, ora conferindo a um, ora a outro, prevalência. ${ }^{359}$ Kallay expressa que as contradições somente começaram a emergir quando as

exposto à concorrência, no sentido de poder haver substitutos para seus produtos. Além disto, direitos de propriedade intelectual são limitados no tempo.

${ }^{356}$ Para Hayek, F. A., a aplicação fiel do conceito de propriedade para bens imateriais contribui de forma efetiva para aumentar o monopólio (HAYEK, F. A. Individualism and Economic Order. Chicago: The University of Chicago Press, 1948, p. 113 e ss.). Já as Diretrizes americanas adotam a equiparação da propriedade intelectual à propriedade usual como princípio geral de aplicação da intersecção entre ambas as disciplinas. Elas também adotam como princípio que a propriedade intelectual não cria a presunção de poder de mercado no contexto do direito antitruste. Vide: US DoJ and FTC; Antitrust Guidelines for the Licensing of Intellectual Property; 1995, p. 2.

${ }^{357}$ Conforme NORTH, D. C. A Recommendation on How to Intelligently Approach Emerging Problems in Intellectual Property Systems, p. 1131: "Na atualidade, não temos uma moldura que nos permita realmente entender como um sistema político funciona e como os direitos de propriedade e de patente evoluíram, logo, não temos um corpo de teoria que nos permita fazer declarações com previsões que nos levariam a melhorar a função dos direitos de propriedade e dos sistemas de patente. O corpo da teoria neoclássica é muito elegante e muito útil, mas não consegue descrever como um sistema está evoluindo. Se queremos entender como funciona o sistema de patentes, não podemos simplesmente basearmo-nos em entender a racionalidade econômica do sistema de patentes [...]" (nossa versão do inglês).

${ }^{358}$ Neste sentido: AHRENS, C. Gewerblicher Rechtsschutz. Tübingen; Mohr Siebeck, 2008, p. 31. O autor recorda que o Tratado de Roma (no âmbito da Comunidade Européia) prevê expressamente no art. 295 a garantia ao direito de propriedade, devendo ser entendido como incluindo-se nele a propriedade intelectual.

Lembramos que a propriedade intelectual não é um direito absoluto, dependendo sua proteção da forma como está sendo exercida. Sua proteção está inserida dentro de um ordenamento jurídico. Conforme outro artigo do Tratado de Roma, art. 30, a propriedade intelectual pode ser justificativa de restrição à importação, exportação ou trânsito na Comunidade Européia, desde que não constitua um meio de discriminação arbitrária ou restrição dissimulada ao comércio entre os Estados-Membros. Vide também: HEINEMANN, A. Das Kartellrecht des geistigen Eigentums im TRIPS-Uebereinkommen der Welthandelsorganisation, p. 536; HASSELBLATT, G. (Hrsg.) Münchener Anwaltshanbuch Gewerblicher Rechtsschutz. Muenchen: Beck, 2005, p. 7 e ss, que argumentam que a propriedade intelectual está in pari materiae com o direito concorrencial.

${ }^{359}$ Vide: BODEWIG, T. Neue Guidelines fuer Lizenzvertraege in den USA. GRUR Int. 1997(12), p. 958 e ss. sobre a evolução jurisprudencial nos EUA.

Inicialmente, teve relevo a teoria que reconhecia um monopólio legal na propriedade intelectual que se identificava com o monopólio para fins do direito antitruste (referimo-nos aos nossos comentários na nota de rodapé 352).

Desenvolve-se, então, outra teoria sob a perspectiva de que os dois ramos do direito se contradizem, o direito da concorrência pretende preservar a concorrência enquanto que a propriedade intelectual pretende restringir a concorrência, concedendo monopólios legais como forma de retribuição aos inventores (este argumento não é acurado, pois o objetivo do direito da propriedade intelectual não é constituição de um monopólio legal, este 
doutrinas de ambos os ramos do direito já estavam bem sedimentadas. A autora expressa que o conflito entre ambos pode ser entendido como parte de uma contradição maior dentro do sistema jurídico, que é a oposição entre a concorrência e a propriedade. Indo além, Kallay identifica o conflito propriedade-concorrência como parte de um conflito ainda mais genérico e, este sim, centenário: o dilema básico da teoria jurídica liberal, segurança versus liberdade de ação. O sistema liberal procura conciliar a segurança individual e liberdade individual. As noções de propriedade estão relacionadas com a segurança individual, já a livre concorrência está relacionada à liberdade individual. ${ }^{360}$

Concordamos que qualquer doutrina sobre a intersecção de concorrência e propriedade intelectual lida, em primeiro plano, com o sopesamento desses interesses básicos, segurança e liberdade, e, em segundo plano, com os outros interesses envolvidos. Os outros interesses surgem da circunstância de que a concorrência implica liberdade de ação e mercado competitivo, que englobam noções econômicas e sociais adicionais; a propriedade intelectual

pode ser uma conseqüência da proteção, mas não está entre suas finalidades) (vide comentários à nota de rodapé 368).

Uma terceira teoria traz que a propriedade intelectual é um exceção ao direito concorrencial. Evidência desta teoria estaria na doutrina do desvirtuamento do exercício da propriedade intelectual. Cabanellas critica a teoria e expressa que para se chegar a esta conclusão é necessário verdadeiro malabarismo conceitual e logicamente indefensável - a distinção entre o direito e seu exercício - que esconde a real intenção da aplicação do antitruste, i.e. prevenir o poder de mercado adquirido com a propriedade intelectual de expandir-se em outros mercados ou setores econômicos (CABANELLAS, G. J. Antitrust and direct regulation of international transfer of technology transactions: a comparison and evaluation, p. 42 e 43). A teoria tenta negar o conflito de ambos os ramos do direito, mas não parece lograr. Muitas vezes, um abuso no exercício do direito anula a proteção por meio da propriedade intelectual, não se trata somente de retirar os efeitos do seu exercício. O âmago do direito de propriedade intelectual pode vir a ser atacado pela regra concorrencial. Esta teoria demonstra que é preciso estabelecer fronteiras para a exceção de aplicação do direito concorrencial à propriedade intelectual. Ascarelli se enquadraria nesta corrente (ASCARELLI, T. Teoria della concorrenza e dei beni immateriali, p. 209 e ss.).

Kallay, D. descreve, ainda uma quarta teoria, a da harmonia dos princípios de ambos os ramos do direito ou a escola do conflito ilusório. Esta corrente afirma que, na esfera de princípios, não há contradição entre propriedade intelectual e direito concorrencial, pois ambos dividem princípios comuns e complementam um ao outro. Estes seriam: maximização do bem-estar e eficiência econômica produzindo o que os consumidores desejam ao menor preço e encorajamento da inovação, da indústria e da concorrência aumentando a eficiência do mercado (KALLAY, D. The Law and Economics of Antitrust and Intellectual Property - An Austrian Approach. Cheltenham/Northampton: Edward Elgar Publishing, 2004). Entendemos que os diferentes focos de ambos os ramos do direito e suas diferentes formas de aplicação ainda podem resultar em um conflito.

Os princípios comuns a ambas as disciplinas são, na realidade, os princípios do ordenamento jurídico no qual estão inseridos, e sua harmonização é um imperativo da aplicação coerente do direito, conforme o ordenamento. Não advém, portanto, esta harmonização dos próprios sub-sistemas jurídicos, mas da necessidade de coesão dentro do ordenamento jurídico. Conforme Dworkin propõe, não há conflito entre princípios de um ordenamento jurídico, mas somente prevalência de um princípio sobre o outro no caso concreto (DWORKIN, R. A matter of principle. Cambridge/London: Harvard University Press, 1985, p. 137). Vide também SALOMÃO FILHO, C. Direito Concorrencial - As Estruturas, p. 207, nota de rodapé 39.

${ }^{360}$ KALLAY, D. The Law and Economics of Antitrust and Intellectual Property - An Austrian Approach, p. 4 e ss. A autora conclui que uma generalização pode ser feita a fim de estender este conflito a toda a ordem jurídica: o modelo da regra da lei versus o modelo da regra do mercado. 
é categoria sui generis de propriedade, mais extensa do que a concepção tradicional, por abranger bens imateriais. ${ }^{361}$

A tensão parece ter se resolvido em torno da idéia de que o direito de concorrência trabalha contra o exercício abusivo dos direitos de propriedade intelectual. ${ }^{362}$ Assim, o direito da concorrência não interfere na fixação da proteção, mas evita que a exclusividade inerente ao direito de propriedade industrial seja assegurada ou reforçada de forma desproporcional, quando cumulada com poder de mercado do titular ou daquele que exerce o direito. $^{363}$

Concordamos, outrossim, com a fragilidade desta acepção, pois que a dicotomia entre a definição do escopo dos direitos e seu exercício é claramente distinguível somente em teoria. Na prática, o legislador não consegue definir os direitos de forma clara o suficiente a fim de evitar que seu exercício se constitua em abuso. A liberdade de concorrência juridicamente tutelada (e que norteia a definição de abuso no exercício) é aquela que foi juridicamente delineada, não o conceito de liberdade em si. $^{364}$ Cabe aos tribunais e à administração fazer a sintonia fina de preencher as lacunas conforme a realidade econômica, legal e tecnológica de cada circunstância. ${ }^{365} \mathrm{O}$ escopo dos direitos é definido no nível político,

\footnotetext{
${ }^{361}$ Quanto à questão do reconhecimento de um direito de propriedade ou outra natureza jurídica à propriedade intelectual, reduzimos nesta passagem a análise sob a ótica do direito de patente e de marcas, somente, aos quais a Lei 9.279/96 expressamente atribui a natureza jurídica de propriedade (Arts. $6^{\circ}$ e 129). Direitos autorais têm como parte integrante da proteção os direitos morais do autor - afinidade estreita com os direitos da personalidade, o que faz com que a sua generalização em torno do instituto da propriedade seja complexa. Não analisaremos este aspecto. Vide: ASCARELLI, T. Teoria della concorrenza e dei beni immateriali, p. 209 e ss., especialmente p. 226. Vide quanto aos direitos autorais: ASCENSÃO, J. O. Direito Autoral. 2. ed. Rio de Janeiro: Renovar, 2007, p. 126 e ss.; DOS SANTOS, M. J. P. A Proteção Autoral de Programas de Computador, p. 51 e ss. Para os princípios orientadores da proteção à marca, especialmente suas funções de origem e de distintividade, vide: MORO, M. C. F. Marcas Tridimensionais - Sua Proteção e os Aparentes Conflitos com a Proteção Outorgada por Outros Institutos da Propriedade Intelectual. São Paulo: Saraiva; 2009, p. 54 e ss.

362 Vide: Deutsche Grammophon GmbH v. Metro-SB-Grossmärkte GmbH \& Co KG, 1971, European Court Reports 487. Vide, ainda, nota de rodapé n. 355.

${ }^{363}$ Vale notar que propriedade intelectual é passível de licenciamento e sublicenciamento, por meio do qual a exclusividade a ela inerente passa a ser exercida no mercado por agentes diferentes dos titulares.

364 Roubier compreende a liberdade de competir como uma liberdade civil: "Esta liberdade comporta normalmente as discussões e lutas em vista de fixar os interesses de uns e de outros; a partir de então encontra-se incluída no funcionamento mesmo desta liberdade a possibilidade de causar danos a outros, e não pode ser de forma diferente, pois o legislador partiu do princípio, caro aos economistas liberais, de que a luta entre interesses particulares para o triunfo dos mais aptos é o melhor meio de servir ao progresso geral da sociedade" (ROUBIER, P. Le Droit de la Proprieté Industrielle. Vol. 1. Paris: Sirey, 1952, p. 527, apud BARBOSA, D. B. Uma Introdução à Propriedade Intelectual, p. 272).

365 Quanto à atuação da administração a este respeito invocamos CASSESE, Sabino. Las bases del derecho administrativo, p. 27: "En la ordenación de los poderes públicos, por tanto, los poderes legislativo y judicial están en una posición recesiva con relación al poder administrativo. Todo ello ha sido destacado por aquellos partindo de Hans Kelsen en 1923 y de Carl Schmitt - que han hablado del Estado moderno como Verwaltungsstaat o 'Estado administrativo', en el sentido de que la Administración, y no a legislación o la actividad jurisdiccional, es el centro de la actividad estatal. Posteriormente, se ha sostenido que las autoridades
} 
pela lei da propriedade intelectual e aplicado, no Brasil, pelo INPI. Ao outorgar o direito de propriedade intelectual o INPI aplica o escopo legalmente definido ao caso concreto. Já o conceito de abuso de exercício do direito é um conceito legal que necessita ainda mais da observação dentro de um determinado contexto, em circunstâncias específicas. Este é inferido da prática pelo titular.

Cabe ao legislador, e não aos tribunais, estreitar o escopo dos diretos de propriedade intelectual. Cabe aos tribunais, e não ao legislador, verificar no caso concreto o abuso no exercício. ${ }^{366}$ Obviamente, o abuso no exercício é verificado posteriormente à concessão do direito.

O ponto primordial para a convergência entre direito da proteção à concorrência e direito da propriedade intelectual está na concepção jurídica de ambos os ramos do direito. A proteção à liberdade e igualdade de todos é pressuposto de qualquer ordenamento do direito privado. ${ }^{367} \mathrm{O}$ monopólio não é o propósito da lei de propriedade intelectual. Existe um caráter individual e um caráter público tanto na proteção à propriedade intelectual quanto na tutela da concorrência. ${ }^{368}$ Depende do prisma de observação. Ambas as leis visam promover a inovação

administrativas, además de administrar, desarrollan una importante actividad normativa y de solución de conflictos" (grifamos). Vide também Capítulo II, Item 2.5.

366 BODEWIG, T. On the Misuse of Intellectual Property Rights. In: HORST, A.; ROSENKRANZ, S. (Org.). Intellectual Property Rights and Global Competition - Towards a New Synthesis. Berlin: Sigma, 1995, p. 232 e ss.

367 Salomão Filho, C., 2004, p. 74 apud Emmerich, Immenga/Mestmäcker GWB Kommentar, Muenchen, Beck, 1992, sub § 35 Rdn 17, p. 1528.

${ }^{368}$ Salomão Filho entende que as regras de direito industrial têm natureza concorrencial e que a concorrência influenciaria a definição das "hipótese legais de incidência" e a definição de ilícitos. Entende que não há complementariedade entre direito industrial e direito concorrencial, e nem derrogação das regras de concorrência pelo direito industrial. $\mathrm{O}$ autor desenvolve este raciocínio com base na origem e função da propriedade industrial e sua evolução até os dias atuais, explicitando que perdeu sua função original e resta remunerando o investimento. Consegue-se o balanceamento do direito industrial com a garantia institucional da concorrência e a utilização de seus princípios publicísticos. Vide: BASSO, M.; SALOMÃO FILHO, C.; POLIDO, F.; CÉSAR. Direitos de Propriedade Intelectual \& Saúde Pública. O acesso universal aos medicamentos anti-retrovirais no Brasil. Instituto de Direito do Comércio Internacional e Desenvolvimento (IDCID), p. 149 e ss.

KALLAY, D. The Law and Economics of Antitrust and Intellectual Property - An Austrian Approach, p. 8 e ss., argumenta que a redução da concorrência não é o propósito da legislação da propriedade intelectual, mas sim um produto incidental deste ramo do direito, que pode vir a se manifestar: "Nenhuma da vasta literatura sobre o propósito da instituição da propriedade intelectual sugere que a redução da concorrência seja uma de suas finalidades. A restrição da concorrência parece ser um possível produto incidental das leis de propriedade intelectual, mais do que um objetivo proposital."

Entendemos que, mesmo com a evolução da proteção à propriedade intelectual - mormente marcas e patentes ao longo dos anos, os componentes publicísticos de (i) promoção da identificação de origem para a marca (intimamente ligada ao direito do consumidor) e da (ii) inovação para a patente não se perderam. Estes são componentes públicos, de interesse público, deste ramo do direito. Argüir-se que a função da patente é proteger o free-riding é esquecer-se que o inventor também pode optar por manter sua invenção secreta, o que efetivamente ocorreria se não fosse o incentivo do monopólio. A publicidade da invenção, de interesse da sociedade, é alcançada em troca da concessão do direito exclusivo de utilização da invenção por período determinado. Conforme Ascarelli, T.: "[...] é com a revolução francesa que, propriamente em relação à 
e a concorrência, ${ }^{369}$ sob perspectivas diferentes. Tanto os direitos de propriedade intelectual quanto o direito da concorrência são necessários para promover a inovação e garantir que ela seja explorada em condições competitivas. ${ }^{370}$ Precisamos de ambos.

A visão da escola econômica austríaca ajusta-se bem a esta idéia de paralelismo entre ambas as disciplinas. A escola austríaca entende a concorrência como objeto teórico distinto dentro da ciência econômica, um processo dinâmico de descoberta, ${ }^{371}$ incentivado pela inovação, a qual modifica de forma substancial o ambiente econômico, na busca por diferenciação e lucros monopolísticos. ${ }^{372}$ Nesse ambiente dinâmico, a propriedade intelectual, assim como o próprio mercado, constituem instituições necessárias para o desenvolvimento e operação da livre-concorrência. A inovação precisa das instituições, logo, a concorrência dinâmica precisa da propriedade intelectual. ${ }^{373}$

afirmação genérica de liberdade de exercício e de concorrência foram ditadas as leis sobre invenções industriais, direito do autor e marcas, com traços fundamentais que permaneceram sucessivamente, conciliando o reconhecimento de um direito absoluto, constituído com base em pressupostos objetivos e desviando-se da discricionariedade da proteção antitruste [p.A.], com a possibilidade de uma utilização geral após o decurso de um certo período de tempo da criação cultural e técnica (obras do engenho, invenções, modelos) e visando promover a sua revelação" (ASCARELLI, T. Teoria della concorrenza e dei beni immateriali, p. 201) (grifamos) (nossa versão do italiano).

Em um ambiente capitalista como o que se delineia a partir da revolução industrial, é natural que se identifique a propriedade intelectual como uma vantagem competitiva e que o seu sub-sistema jurídico envolva normas de cunho concorrencial. Novamente, a concorrência vigia o exercício do direito e não lhe determina o conteúdo. Alguns desenvolvimentos recentes no escopo da proteção em alguns países implicam, na nossa opinião, desvios de finalidade dos direitos de propriedade intelectual, porém, lembramos novamente, a definição do escopo do direito é legislativa e política. Entendemos que a concessão de proteção a bases de dados sem originalidade na Europa e o patenteamento de métodos de negócios nos EUA são exemplos de desvios de finalidade da proteção por meio da propriedade intelectual. Daí a argüir-se que a mera função da propriedade industrial é disciplinar a concorrência e que ela não seria disciplina extravagante em relação ao direito concorrencial, mas sim um caso especial de sua aplicação, é um caminho que não tomaremos.

${ }^{369}$ US DoJ e FTC; Antitrust Guidelines for the Licensing of Intellectual Property; 1995, p. 2, mencionando: Atari Games Corp v. Nintendo of America, Inc., 897 F.2d 1572, 1576 (Fed. Cir. 1990).

${ }^{370}$ Diretrizes sobre a Aplicação do Art. 81 do Tratado da Comunidade Econômica Européia a Contratos de Transferência de Tecnologia - Guidelines on the Application of Article 81 of the EC Treaty to Technology Transfer Agreements - 2004/C.101/02.

${ }^{371} \mathrm{O}$ modelo de concorrência dinâmico assume um processo de mercado naturalmente auto-sustentável e talvez até mesmo auto-regulador - Vide KALLAY, D. The Law and Economics of Antitrust and Intellectual Property An Austrian Approach, p. 102). Já a escola tradicional assume a configuração estática de mercado tradicional, a concorrência perfeita, inatingível, como base para a análise econômica concorrencial tradicional - Vide comentários de POSSAS, M. L. Limites normativos da análise econômica antitruste. Revista do IBRAC 2009(1), p. 236.

${ }^{372}$ SCHUMPETER, J. A. Capitalism, Socialism and Democracy. New York: Harper Colophon, 1975, p. 81 e ss.; p. 414 e ss. Conforme p. 84: "[...] Mas na realidade capitalista distinta da visão dos livros teóricos, não é este tipo de concorrência que conta, mas a concorrência da nova commodity, a nova tecnologia, nova fonte de fornecimento, novo tipo de organização (por exemplo, a unidade de controle em escala máxima) - concorrência que comanda um custo ou vantagem de qualidade decisivos e que não se orienta para as margens de lucro e produtividade das firmas existentes, mas sim em seus fundamentos e sua própria vida". (nossa versão do inglês).

373 Conforme KALLAY, D. The Law and Economics of Antitrust and Intellectual Property - An Austrian Approach, p. 104 - "A análise austríaca admite que o processo de mercado naturalmente robusto e sem interferência que ela pretende requer um certo grau mínimo de intervenção governamental, na forma de reconhecimento de direitos de propriedade. Assim, a metodologia austríaca exorta que o governo não deve 
A inovação é componente fundamental de uma economia de mercado. Os direitos de propriedade intelectual reforçam a concorrência dinâmica, incentivando as empresas a investirem no desenvolvimento de produtos e de novos processos melhorados.

\subsection{Especificidades quanto ao contrato de transferência de tecnologia}

A característica fundamental e o direito principal do titular de segredo de negócio é a faculdade de restringir o acesso e o uso da informação secreta, subjacente ao segredo de negócio. A faculdade e principal aspecto da proteção para o titular torna-se também uma obrigação, pois a perda da confidencialidade gerará a perda da proteção da informação. ${ }^{374}$

Assim, enquanto na patente o titular tem o direito de restringir o uso e gozo da informação durante período limitado de tempo, conforme o mandamento legal, no segredo de negócio o direito de restringir o uso e gozo da informação é vinculado à manutenção do segredo pelas partes que tenham acesso à informação. Não há um prazo máximo estipulado por lei, mas há o pré-requisito da confidencialidade para que receba a proteção indireta pela propriedade industrial. Em um contrato envolvendo segredo de negócio, a licença apenas poderá ser negativa, ou seja, o licenciador abster-se de fazer valer seu direito de defesa contra o licenciado. ${ }^{375} \mathrm{O}$ segredo de negócio é explorado por meio da transferência contratual protegida e restrita. Não há um direito à informação, mas sim um direito à sua obtenção legítima.

$\mathrm{Na}$ contratação da transferência de tecnologia o território mais fértil para os conflitos entre a propriedade intelectual e o direito da concorrência certamente é o das práticas restritivas de negócio. É usual o contrato conter cláusulas que protejam a tecnologia contra o abuso pela parte recipiente, por meio de cláusulas restritivas que controlem a

interferir no processo natural de mercado, com exceção da proteção à propriedade privada e às instituições libertárias necessárias para assegurar-se uma ordem competitiva eficaz" (nossa versão do inglês).

Conforme Irti: "Não se conhece como verdadeiro algum mercado (mercado determinado no tempo e no espaço) que não pressuponha institutos jurídicos: também a elementar distinção do 'meu' e 'teu', da qual procede todo ato de troca, implica a remissão a um critério determinativo. O mercado não cria, mas postula a distinção entre 'meu' e 'teu', e então que os bens sejam reconhecidos como propriedade privada, e não como propriedade comum" (IRTI, N. A Ordem Jurídica do Mercado. Palestra proferida no seminário: O Estado, A Empresa e o Mercado - Novas Tendências do Direito Econômico e Comercial - ministrado na Faculdade de Direito da Universidade de São Paulo, em 10/09/2007 - resenha distribuída aos presentes, p. 4).

Vide também: HAYEK, F. A. Individualism and Economic Order, p. 112.

${ }^{374}$ Vide Capítulo I Item 3.

${ }^{375}$ AHRENS, C. Gewerblicher Rechtsschutz, p. 163. 
liberdade de ação do recipiente ao aplicá-la. Alterar-se a faculdade do detentor do segredo de negócio de impor essas restrições, regulando-as, é tarefa que exige bastante ponderação, a fim de não anular totalmente a sua vantagem competitiva.

Restrições à concorrência inseridas num contrato de tecnologia não patenteada somente serão aceitáveis se relacionadas diretamente ao direito protegido (no caso do segredo de negócio, se relacionadas ao monopólio fático protegido pela concorrência desleal). Logo, (i) o objeto do contrato deve ter valor econômico; (ii) a restrição deve se limitar à duração da confidencialidade do objeto e (iii) as restrições devem atingir somente produtos ou serviços diretamente relacionados à informação que constitui o segredo de negócio. Conforme Barbosa, trata-se de uma limitação objetiva da restrição. ${ }^{376}$ As limitações em contratos de fornecimento de segredo de negócio devem permitir o exercício da proteção conferida pela concorrência desleal e não ir além dela. Assim, por exemplo, cláusulas que exigissem a restrição de divulgação de informações que não são confidenciais e, portanto, não protegidas por segredo de negócio não são admitidas.

Para fins do direito da concorrência e sopesamento de interesses envolvidos na regulação, em não existindo a proteção pela propriedade intelectual, ou em não existindo segredo sobre a tecnologia, não haveria de se falar em aplicação diferenciada das normas concorrenciais às cláusulas restritivas do contrato.

As disposições do TRIPS sobre práticas restritivas de negócio se referem à existência, abrangência e exercício dos direitos de propriedade intelectual. A Nota 3 do Acordo TRIPS define "proteção" como incluindo assuntos relativos à disponibilidade, aquisição, escopo, manutenção e execução dos direitos de propriedade intelectual bem como matérias que afetem o uso da propriedade intelectual e que estejam especificamente mencionadas no acordo. ${ }^{377}$ Politicamente, negociou-se restrições que poderão ser efetuadas pelos governos dos países-membros, sem que sejam consideradas uma limitação indevida da existência, abrangência e exercício da propriedade intelectual.

Entendemos que o registro do contrato pelo INPI, executado dentro da finalidade da política industrial e tecnológica do país, ${ }^{378}$ implicaria a revisão de harmonização das

\footnotetext{
${ }^{376}$ BARBOSA, D. B. Uma Introdução à Propriedade Intelectual, p. 1025 e ss.

${ }^{377}$ Também o art. 63.1 do TRIPS lista a prevenção do abuso de direitos de propriedade intelectual como matéria afeita ao TRIPS.

${ }^{378}$ Decreto 5.147/04 Anexo I art. 13.
} 
cláusulas contratuais com o interesse coletivo, dentro da função da autarquia de executar as normas que regulam a propriedade industrial tendo em vista sua função social, econômica,

jurídica e técnica, ${ }^{379}$ o que claramente inclui a aplicação em território nacional das disposições do TRIPS, internalizadas e parte integrante do direito pátrio. O grande desafio da regulação está em lograr a promoção da difusão e absorção da tecnologia localmente sem desincentivar a transferência de tecnologia em si.

Assim, estar-se-ia dentro de uma função de revisão de cláusulas a fim de verificar sua harmonia com a legislação nacional, tendo como embasamento o interesse coletivo de promoção da livre-concorrência, incluindo, na função de promoção da concorrência nos mercados, a necessidade de absorção e difusão de tecnologia. No âmbito da União Européia, a regulamentação destas cláusulas em contratos de transferência de tecnologia já existe e está em sua terceira versão. ${ }^{380}$

\subsection{A absorção e a difusão de tecnologia delineada nas cláusulas contratuais.}

Já adiantamos no Item 1 deste Capítulo que há diferentes finalidades e funções entre a análise das práticas restritivas de um contrato de transferência de tecnologia por meio de regulação específica ou por meio do direito da concorrência.

Ao analisar comparativamente as regulações sobre transferência de tecnologia existentes na América Latina nas décadas de setenta e oitenta, Cabanellas identificou os seguintes princípios da regulação: ${ }^{381}$ (i) melhorar o poder de barganha do receptor local de tecnologia; (ii) promover o desenvolvimento local de tecnologia, melhorando a qualidade e assimilação local da tecnologia transferida; (iii) proteger a inovação local e a tecnologia local; (iv) melhorar a informação disponível às partes locais sobre possíveis fontes de tecnologia; (v) equilibrar a balança de pagamentos do país receptor; (vi) controle de operações de câmbio e comércio exterior; (v) prevenir a evasão fiscal; (vi) limitar a proteção à propriedade industrial; (vii) controlar a natureza da tecnologia importada; (viii) regular investimentos

\footnotetext{
${ }^{379}$ Lei 5.648/70, art. $2^{\circ}$.

${ }^{380}$ Vide Item 3 infra.

${ }^{381}$ CABANELLAS, G. J. Antitrust and direct regulation of international transfer of technology transactions: a comparison and evaluation, p. 30 e ss.
} 
estrangeiros. Acrescentamos a aplicação da legislação relativa ao direito da concorrência, prática específica do Brasil em relação às demais regulações existentes na América Latina, conforme analisaremos no Item 4.1 infra.

O grande desafio da regulação está em lograr a promoção da difusão e absorção da tecnologia localmente sem desincentivar a transferência de tecnologia em si. Resta claro que uma regulação não específica, baseada somente no direito concorrencial geral, não terá a capacidade de desincentivar a operação de transferência de tecnologia, ao menos em relação às demais alternativas para operações comerciais no país, pois a transferência de tecnologia estaria sujeita aos mesmos controles que todas as outras operações comerciais. ${ }^{382}$ Porém, as operações de transferência de tecnologia ficariam destituídas de estímulo exógeno à difusão e absorção da tecnologia. Apesar de ter interesse na maior absorção possível da tecnologia em território nacional, a parte brasileira pode não conseguir negociá-la contratualmente. Já a difusão em território nacional, não é de interesse para nenhuma das partes do contrato, já que o receptor brasileiro deve desejar manter a tecnologia em seu domínio restrito, usufruindo da vantagem competitiva.

Estudo da UNCTAD demonstra que a aplicação de cláusulas de transferência de tecnologia em contatos de licenciamento é mecanismo recomendado fortemente para a governança de conhecimento ${ }^{383}$. O termo cláusulas de transferência de tecnologia entende-se como aquelas cláusulas que limitam a possibilidade de uma licença de segredo de negócio, de forma paralela com a licença de marcas e de patentes. ${ }^{384}$

É usual o contrato de transferência de tecnologia baseado em segredo de negócio conter cláusulas que protejam a tecnologia contra o abuso pela parte recipiente, por meio de

\footnotetext{
${ }^{382}$ A Abimaq - Associação Brasileira de Máquinas e Indústrias, coordenou estudo que mede o 'Custo Brasil' em relação a outros países do mundo. Concluiu-se que este custo fica na média de $36,27 \%$ - sendo composto de: impostos não recuperáveis na cadeia produtiva: $2,98 \%$; encargos sociais e trabalhistas $2,84 \%$; logística $1,90 \%$; burocracia e custos de regulamentação $0,36 \%$; custos de investimento $1,16 \%$ e custos de energia $0,51 \%$. Apenas investir em equipamentos, processos, tecnologia e inovação não basta diante do peso do Custo Brasil. Os favorecidos são os setores produtores em grande escala de bens intensivos em recursos naturais e com menor capacidade de agregação de valor. É o avanço do processo de 'commoditização' da indústria brasileira, o que significa desindustrialização. Conforme Júlio Sérgio Gomes de Almeida, do Iedi: "Corremos o risco de ver parte do setor produtivo ser transformado em montador, numa indústria que só tem casca e cujo conteúdo vem de fora". O Estado de São Paulo, Caderno Economia, 08/03/2010.

${ }^{383}$ UNCTAD - United Nations Conference on Trade and Development. The Least Developed Countries Report 2007 Knowledge, Technological Learning and Innovation for Development,p. XI.

${ }^{384}$ Conforme analisamos no Capítulo I Item 4.2 deste trabalho, em se tratando de um direito mesmo de propriedade intelectual e não em um monopólio de fato como no caso do segredo de negócio, desenvolveu-se a figura da licença do direito intangível, pela qual a informação não se transfere, mas somente o seu uso por certo prazo.
} 
cláusulas restritivas que controlem a liberdade de ação do recipiente ao aplicá-la. Alterar-se a faculdade do titular de impor essas restrições, regulando-as, é tarefa que exige bastante ponderação, a fim de não anular totalmente a vantagem competitiva do titular, seu direito. Porém, é, também, o modo de influir na absorção e difusão do conhecimento.

As cláusulas essenciais do contrato de fornecimento de tecnologia sob a modalidade de transmissão de conhecimentos protegidos sob segredo de negócio são: ${ }^{385}$ (i) cláusula pela qual o fornecedor comunica as informações definidas no contrato; (ii) cláusula por meio da qual o receptor se compromete a receber a informação e zelar pelo seu valor manutenção do segredo ou escassez das informações; e, (iii) em contratos onerosos, cláusula pela qual o receptor se compromete a retribuir financeiramente o fornecedor pelo recebimento das informações. Retirar do contrato de fornecimento de tecnologia quaisquer destas cláusulas livremente negociadas entre as partes afeta-lhe a natureza.

A cláusula de manutenção de segredo, item (ii) acima, pode assumir várias vertentes. Pode limitar o escopo de pessoas com acesso ao conhecimento, impondo proibição de transmissão a terceiros em geral. Pode permitir de forma restrita a transmissão da informação a terceiros, por exemplo na hipótese de subcontratação. Relativamente à duração, as cláusulas de sigilo podem ser de prazo igual ao prazo contratual ou além do contratual, inclusive de prazo indeterminado. O esvaziamento integral do conteúdo desta cláusula retirará a proteção legal da informação.

Outras cláusulas usuais ${ }^{386}$ em contratos, que regulamentam o uso e disposição da tecnologia protegida por segredo de negócio são cláusulas de:

\footnotetext{
${ }^{385}$ Vide BARBOSA, D. B. Uma Introdução à Propriedade Intelectual, p. 1018 e 1019. Conforme Ascarelli, T.: "Aquele que comunica um dado pode, à outra parte, impor um vínculo de não divulgação (e, conseqüentemente, de não transmissão) a cargo do destinatário, e assim consentir com sua utilização. É freqüente que a comunicação do segredo industrial ocorra a título oneroso [...]. Nesta hipótese não há propriamente uma transmissão do segredo, que não é uma coisa, mas um 'fazer' (comunicar) ou um dar (transmissão de desenhos, fórmulas, etc.) a título oneroso e com vínculo (aquele de não fazer) quanto à divulgação (vínculo frequientemente imposto adicionalmente a quem comunica o dado, assim como àquele a quem vem comunicado)" (ASCARELLI, T. Teoria della concorrenza e dei beni immateriali, p. 196).

${ }^{386}$ Contratos de transferência de tecnologia não obedecem a uma padronização de cláusulas típica, a sua forma de contratação é variada. Conforme a Coordenadora Geral de Contratos de Transferência de Tecnologia, da Diretoria de Transferência de Tecnologia Contratos e de Outros Registros, DIRTEC, Lia de Medeiros: "Em transferência de tecnologia, a possibilidade de adoção de um modelo contratual é remota ou mesmo impossível. Comumente, tem-se: I - Partes; II - Considerações; III - Definições; IV - Objeto; V - Território; VI Confidencialidade; VII - Pagamentos; VIII - Assistência Técnica; IX - Lei Aplicável ; XI - Arbitragem" Palestra Propriedade Intelectual e Transferência de Tecnologia proferida em 21 de junho de 2007 no painel Setorial da Inmetro. Disponível em: <www.inmetro.gov.br/painelsetorial/palestras/INPI.pdf>. Acesso em: 18/09/2009.
} 
(i) exclusividade de uso, as quais limitam a utilização do conhecimento por terceiros;

(ii) limitação de escopo geográfico ou territorial de atuação no uso da tecnologia, ou venda de produtos/serviços que a incorporam,

(iii) limitação de área de aplicação/uso da tecnologia conforme produtos/segmento;

(iv) limitação de uso da tecnologia pela parte receptora após prazo contratual;

(v) necessidade de fornecimento de melhorias e aperfeiçoamentos feitos na tecnologia pela parte receptora à fornecedora;

(vi) pagamento de níveis mínimos de remuneração, independente de performance;

(vii) impõem a compra de insumos e componentes de terceiros determinados;

(viii) imposição de receber e pagar por um pacote total de tecnologia, relativo a vários produtos e serviços diferentes;

(ix) legitimação da parte brasileira para agir em juízo em defesa da parte estrangeira;

(x) cláusulas que proíbem o questionamento judicial da tecnologia e seu status de segredo de negócio pela parte receptora;

(xi) imposição do preço de revenda do produto ou do serviço oriundo da tecnologia;

A faculdade de proibir o uso pelo licenciado além dos limites estritamente delineados na autorização de uso (i.e. licença) é amparada por lei no caso dos direitos de propriedade industrial propriamente ditos, pois ao titular é concedido monopólio legal. Somente o uso autorizado é permitido, qualquer uso além da autorização constitui violação do direito. Já no caso do segredo de negócio, em não havendo monopólio legal, mas somente de fato, não há uma proteção ou um direito a licenciar o segredo de negócio. A proteção que o titular poderá impor é a contratual; nada impede que o detentor do segredo de negócio 
delineie o contrato como se de licença fosse. Porém, novamente voltamos ao assunto tratado no Capítulo I, Item 4.2, sendo o segredo de negócio informação, uma vez transferida não há como obrigar-se a sua restituição ou apagar-se o aprendizado. O que nos força a concluir que, em impondo a transferência efetiva da informação sob o contrato de fornecimento de segredo de negócio, o Estado está influenciando os limites do direito, mas sem descumprir a legislação, já que o monopólio do detentor é de fato e não legal. Estamos fora do âmbito do direito da concorrência, já que não se trata de impor limites ao exercício de direito, pois que o segredo e controle da informação é do âmago mesmo do segredo de negócio.

O canal de transferência de tecnologia não é uma forma fácil de construir capacidade de inovação. Por meio deste, as consequiências da transferência de tecnologia serão determinadas pelos objetivos gerais das corporações que contratam, os quais certamente não englobam a disseminação da tecnologia para potenciais concorrentes. Em países em desenvolvimento, o poder de barganha das corporações receptoras na negociação é bastante reduzido, conforme analisamos no Item 1.1 supra. Há um nível elevado de dependência dos fornecedores estrangeiros, pela não abundância de tecnologia localmente desenvolvida. Há, também, uma relativa falta de informação sobre as tecnologias disponíveis na área, originada entre outras razões da falta de pessoal técnico para avaliar as tecnologias oferecidas. A simples abertura das portas ao investimento estrangeiro realmente não gerará incremento da base tecnológica local.

$\mathrm{Na}$ atual realidade comercial, as fontes de novas tecnologias se multiplicaram, surgiram tecnologias genéricas, com vasta área de aplicação. A diversificação e interdependência de produtos e empresas também aumentaram, assim como os custos de pesquisa e desenvolvimento e a exigência de atender o mercado mundialmente. Granstrand aponta para o aumento no comércio de tecnologia e de estratégias de licenciamento, aumento nas taxas de royalties, indicativos de que uma era pró-licenciamento pode estar emergindo. $\mathrm{O}$ maior receio das empresas que licenciam suas tecnologias é o risco de estar-se gestando futuros competidores e uma menor competitividade da própria empresa, pela perda de vantagens tecnológicas específicas da corporação. ${ }^{387}$ Para as empresas dos países industrializados que atuam como licenciadas, o papel da licença é complementar ao da pesquisa e desenvolvimento internos, funcionando como forma de encalço do padrão tecnológico e diversificação de atuação.

\footnotetext{
${ }^{387}$ GRANDSTRAND, O. The Economics and Management of Technology Trade: Towards a Pro-Licensing Era? International Journal of technology Transfer and Commercialisation 2004(27), p. 209 e ss.
} 
Analisamos no Capítulo II os vértices usados pela regulação brasileira e sua inadequação ao atual contexto econômico do país. Assim, entre os objetivos regulatórios identificados por Cabanellas ainda reconhecemos no contexto atual da regulação brasileira a necessidade dos seguintes vértices: (a) promoção do desenvolvimento local de tecnologia, melhorando a qualidade e assimilação local da tecnologia transferida, (b) proteção à inovação local e à tecnologia local. Abandonam-se as linhas-mestras interpretativas com base na balança de pagamentos, evasão fiscal, controles sobre a atividade matriz-subsidiária.

Os vértices remanescentes (a) e (b) supra indicados são perfeitamente compatíveis com os princípios do direito de propriedade intelectual baseados na promoção da inovação. Os quais, por sua vez, interagem com o vértice da repressão ao abuso de poder econômico da legislação concorrencial. Dessa forma, entendemos que o Estado deve focar em políticas com medidas de prevenção a (i) práticas anticompetitivas pelos detentores dos direitos sobre a tecnologia e (ii) práticas que impeçam "indevidamente" a transferência e disseminação de tecnologia. O conteúdo que se concederá ao "indevidamente" será definido pela política industrial e de inovação do país, tendo em vista o interesse coletivo. O controle destas práticas é bastante comum em países desenvolvidos, mas é comum a falta de medidas legislativas nesta área nos países em desenvolvimento.

A fim de fundamentar as práticas restritivas a serem aceitas ou não em contratos de transferência de tecnologia para o Brasil, é preciso adotar raciocínio diferente do usual para as restrições de negócios e sua análise concorrencial. Ao invés de tolerar o monopólio ou a concentração de poder entendendo-os como resultado dos direitos de propriedade intelectual, prega-se na regulação da transferência de tecnologia justamente uma postura mais restritiva às limitações contratuais impostas pelo fornecedor da tecnologia do que o próprio direito da concorrência imporia. Não se trata de imunizar o segredo de negócio da aplicação da regra concorrencial, mas de limitar as práticas negociais a ele relacionadas ainda mais do que o direito concorrencial limitaria. Ao tratar de limites em relação a (i) exclusividade de uso; (ii) limitação de uso da tecnologia após prazo contratual; lidamos, no caso do segredo de negócio, com a confidencialidade da informação e seu controle, com os limites mesmo de proteção da propriedade intelectual e não com o seu exercício.

É por isto que os países desenvolvidos negociam e tentam influenciar internacionalmente a adoção de restrições baseadas no direito da concorrência, somente. 
Entre o escopo de atuação do exercício do direito, sob a tutela da concorrência, teríamos as seguintes cláusulas: (i) limitação de escopo geográfico ou territorial de atuação no uso da tecnologia, (ii) limitação de área de aplicação da tecnologia conforme produtos/segmento; (iii) necessidade de fornecimento de melhorias e aperfeiçoamentos feitos na tecnologia pela parte receptora à fornecedora; (iv) pagamento de níveis mínimos de remuneração, independente de performance; (v) imposição da compra de insumos e componentes de terceiros determinados; (vi) imposição de receber e pagar por um pacote total de tecnologia, relativo a vários produtos e serviços diferentes; (vii) proibição do questionamento judicial da tecnologia e seu status de segredo de negócio pela parte receptora; (viii) imposição do preço de revenda do produto ou do serviço oriundo da tecnologia; a análise concorrencial requer a verificação de poder de mercado, logo, não haveria uma ilegalidade per se, mas analisada caso a caso, implicando, inclusive, um poder de mercado por parte de quem aplica a restrição.

Na Comunidade Européia, a regulação que desponta é claramente múltipla em termos de finalidades. A ela não interessa regular somente a questão sob o prisma concorrencial da promoção do comércio livre de barreiras dentro do mercado comum europeu. A repressão ao abuso de poder econômico é instrumentalizada também pela promoção da difusão e inovação tecnológica dentro do território europeu. Trata-se de uma concorrência instrumentalizada, em que determinadas cláusulas não são aceitas nas contratações, independente da participação de mercado dos agentes.

Ao governo brasileiro cabe delinear de forma mais clara em sua política industrial o tipo e maneira de controles que pretende exercer sobre a importação de tecnologia para o país, e com qual finalidade. Adicionalmente, é preciso promover uma harmonização dos vários diplomas legais incidentes na operação para que expressem coerência entre si. A coerência será atingida na medida em que se escolha os vetores definidores da regulação de forma consistente.

Analisaremos a seguir a moldura imposta pelo TRIPS à regulação, este sim um limite real para a atuação da lei brasileira. 


\section{As Práticas Restritivas em Contratos de Licença no TRIPS}

Conforme expomos neste trabalho ${ }^{388}$, as disposições sobre concorrência do TRIPS resultam de um compromisso entre países desenvolvidos e em desenvolvimento e são, portanto, uma exceção ou reserva à proteção da propriedade intelectual. O TRIPS é o acordo no âmbito da OMC com o maior número de dispositivos de cunho concorrencial, já que esta disciplina não logrou obter harmonização em tratados internacionais específicos. ${ }^{389}$

Referidas disposições refletem a aproximação de desenvolvimento baseado no mercado para a regulação da transferência de tecnologia. A política delineadora está centrada na crença de que o encorajamento da transferência de tecnologia será melhor alcançado em um ambiente no qual os direitos de propriedade intelectual sejam completamente protegidos e sujeitos à propriedade privada e no qual o mercado de tecnologia seja mantido num ambiente o mais competitivo possível. A justificativa alegada pelos países em desenvolvimento é que esse modelo é capaz de contornar os desincentivos comerciais que um modelo centrado em uma regulação estatal forte pode criar.

Assim, com o TRIPS a ênfase migrou da regulação de operações de transferência de tecnologia no interesse da parte mais fraca - normalmente a parte recipiente da tecnologia em um país em desenvolvimento - para um modelo baseado em um mercado aberto, no qual a transferência de tecnologia para países em desenvolvimento deva ser encorajada pela própria operação do mercado, em conjunto com assistência e cooperação por parte dos países desenvolvidos. Acredita-se que a criação de condições de mercado aptas a aumentar o investimento estrangeiro poderá levar ao aumento da transferência de tecnologia como parte do processo de investimento.

A política e ação governamental não é totalmente abandonada nesta aproximação, encoraja-se a transferência de tecnologia por meio de programas governamentais e incentivos às firmas, efetuados pelos governos dos países desenvolvidos, não dos países em desenvolvimento. 390

\footnotetext{
${ }^{388}$ Vide Item 1. supra e Capítulo I Item 6.3.

389 HEINEMANN, A. Das Kartellrecht des geistigen Eigentums im TRIPS-Uebereinkommen der Welthandelsorganisation. GRUR Int. 1995(7), p. 535. Heinemann enumera especificamente os arts. VIII e IX do GATS como relativos à concorrência em relação a serviços.

${ }^{390}$ UNCTAD - United Nations Conference on Trade and Development. Transfer of Technology, p. 64. O relatório esclarece que posições semelhantes estão contidas no (i) Tratado da Carta de Energia - Energy Charter
} 
As cláusulas do TRIPS relacionadas a regras de concorrência estão dispostas no Preâmbulo e nos arts. 8 2), 31 k) e 40 1) e 2) do acordo. ${ }^{391}$ Conforme o primeiro parágrafo do Preâmbulo:

Desejando (...) promover uma proteção eficaz e adequada aos direitos de propriedade intelectual e assegurar que as medidas e procedimentos destinados a fazê-los respeitar não se tornem, por sua vez, obstáculos ao comércio legítimo; [...]

Heinemann entende que este item atenta para a aparente relação de conflito genérica entre a proteção da propriedade intelectual e a proteção à concorrência e da necessidade de se encontrar um balanceamento entre ambas as proteções. ${ }^{392}$ A questão genericamente colocada no Preâmbulo esmiúça-se, então, nos artigos específicos dedicados à matéria.

$\mathrm{O}$ artigo $8^{\circ}$, item 2., dos Princípios, dispõe:

2- Desde que compatíveis com o disposto neste Acordo, poderão ser necessárias medidas apropriadas para evitar o abuso dos direitos de propriedade intelectual por seus titulares ou para evitar o recurso a práticas que limitem de maneira injustificável o comércio ou que afetem adversamente a transferência internacional de tecnologia.

Esse artigo reconhece a faculdade ${ }^{393}$ dos países-membros de adotar em sua legislação doméstica medidas apropriadas para prevenir três tipos principais de práticas relacionadas aos direitos de propriedade intelectual: (i) abuso desses direitos; (ii) práticas que restrinjam o comércio de forma desarrazoada e (iii) práticas que afetem de maneira adversa o comércio internacional de transferência de tecnologia, cobrindo tanto práticas unilaterais como restrições contratuais. Assim, não há uma proteção absoluta dos direitos de propriedade intelectual, não há uma imunidade destes em relação às normas de concorrência no TRIPS.

Treaty (art. $8^{\circ}$ ); (ii) GATS [art. IV (1) (a)]; (iii) Recomendações OCDE para Empresas Multinacionais - OECD Guidelines for Multinational Enterprises (Chapter 8); (iv) Conjunto de Princípios Equiparáveis e de Regras para o Controle de Práticas Restritivas de Negócios Acordados Multilateralmente - Set of Multilaterally Agreed Equitable Principles and Rules for the Control of Restrictive Business Practices - Resolução 35/63 (1980) da Assembléia Geral das Nações Unidas; (v) NAFTA (art. 1704).

${ }^{391}$ Não faremos a análise do Art. $31 \mathrm{k}$ ) por tratar de licença compulsória de direitos de patentes; a tecnologia objeto de patente não é o foco do presente estudo.

392 HEINEMANN, A. Das Kartellrecht des geistigen Eigentums im TRIPS-Uebereinkommen der Welthandelsorganisation, p. 536 e ss.

${ }^{393}$ Importante salientar que, como cláusula de exceção, insurgir-se contra o abuso dos direitos de propriedade intelectual torna-se uma faculdade dos países membros e não um dever. Vide neste sentido: HEINEMANN, A. Das Kartellrecht des geistigen Eigentums im TRIPS-Uebereinkommen der Welthandelsorganisation, p. 536 e 538, e ICTSD - International Centre for Trade and Sustainable Development. Intellectual Property and Competition Law - Exploring Some Issues of Relevance to Developing Countries. Issue Paper 21. Geneva, 2007, p. 2. 
Já o artigo 40, inserido na Seção 8, de Controle de Práticas de Concorrência Desleal em Contratos de Licenças, é a regra especial relativa a restrições contratuais em relação ao artigo 8) 2). Observa-se a seguinte redação em seus Itens 1) e 2):

1 - Os Membros concordam que algumas práticas ou condições de licenciamento relativas a direitos de propriedade intelectual que restringem a concorrência podem afetar adversamente o comércio e impedir a transferência e disseminação de tecnologia.

2 - Nenhuma disposição deste Acordo impedirá que os Membros especifiquem em suas legislações condições ou práticas de licenciamento que possam, em determinados casos, constituir um abuso dos direitos de propriedade intelectual que tenha efeitos adversos sobre a concorrência no mercado relevante. Conforme estabelecido acima, um Membro pode adotar, de forma compatível com as outras disposições deste Acordo, medidas apropriadas para evitar ou controlar tais práticas, que podem incluir, por exemplo, condições de cessão exclusiva, condições que impeçam impugnações da validade e pacotes de licenças coercitivos, à luz das leis e regulamentos pertinentes desse Membro. [...] (grifos nossos) $)^{394}$

Vale ressaltar que a utilização da expressão "afetar adversamente o comércio e impedir a transferência e disseminação de tecnologia" deve ser interpretada tanto quanto a restrição à entrada quanto à saída de tecnologia. Entendemos que a lista de cláusulas restritivas constantes do Item 2 não é exaustiva, já que a própria redação do Item assim dispõe. ${ }^{395}$ Ademais, o conceito de cláusula restritiva deve ser interpretado de forma ampla. ${ }^{396}$ 397

Dessa forma, argumentamos que as regras concorrenciais do TRIPS conferem aos países-membros discrição substancial para estabelecer suas próprias regras relativamente ao assunto. A limitação, por sua vez, está na necessidade das medidas serem "compatíveis com o TRIPS", "apropriadas" e "necessárias para evitar ou controlar as práticas", conforme o item 2 do art. 8 reproduzido supra.

\footnotetext{
${ }^{394}$ Vale ressaltar que o art. 40 constitui-se, ainda, de dois itens adicionais: itens 3 e 4, os quais lidam com um processo de consultas recíprocas entre países membros para a hipótese de violações à concorrência que produzam efeitos em mais de um país. Trata-se de regra específica para cláusulas em contratos de licença, por estar incluída sob o art. 40. Não trataremos destes dois Itens no presente trabalho. Vide HEINEMANN, A. Das Kartellrecht des geistigen Eigentums im TRIPS-Uebereinkommen der Welthandelsorganisation, p. 538, para comentários a respeito.

${ }^{395}$ Nguyen lembra, ainda, que a minuta de Bruxelas do art. 40 do TRIPS listava 14 (catorze) práticas anticoncorrenciais, as quais, por sua vez, constavam do TOT Code (versão de 1985) (NGUYEN, T. T., p. 558-586).

${ }^{396}$ O termo "práticas concorrenciais anti-competitivas" já foi interpretado de forma extensiva, conforme o Painel OMC "México-Medidas que Afetam Serviços de Telecomunicação" - WT/DS204/R (NGUYEN, T. T. The CFI's Ruling in Microsoft v. Commission, p. 560).

${ }^{397}$ Heinemann entende que as cláusulas listadas não podem ser consideradas per se como restritivas da concorrência, mas como cláusulas indicativas de haver, no caso concreto, uma obstrução à concorrência (HEINEMANN, A. Das Kartellrecht des geistigen Eigentums im TRIPS-Uebereinkommen der Welthandelsorganisation, p. 538).
} 
Em relação à consistência ou compatibilidade com o TRIPS, Nguyen argumenta que esse requisito implica dois aspectos: (i) as regras de concorrência domésticas, seus regulamentos e sua execução devem cumprir com os princípios fundamentais do TRIPS e dos Acordos $\mathrm{OMC}^{398}$ e (ii) com os padrões mínimos de proteção neles estabelecidos.

As regras concorrenciais do TRIPS se aplicam sobre as regras concorrenciais gerais dos países-membros. Assim como todos os princípios fundamentais dos acordos relativos à OMC também se aplicam, desde que internalizados pelo ordenamento pátrio. Logo, tratamento nacional, exceção da nação mais favorecida e transparência são princípios que deverão nortear o delineamento nacional da intersecção entre propriedade intelectual e antitruste.

Para o Brasil, resta como relevante notar que a regulação da transferência de tecnologia protegida por segredo de negócio não poderá distinguir entre a importação de tecnologia e a tecnologia obtida localmente no mercado interno. De certa forma, isto coíbe a intenção que existia na regulação latino-americana de compensar o desnível tecnológico norte-sul fortalecendo a posição do receptor latino-americano. Ademais, qualquer limitação específica para contratos entre empresas pertencentes ao mesmo grupo econômico, com vinculação majoritária de capital, resta prejudicada, pois não terá relevância de uma perspectiva concorrencial. ${ }^{399}$ São pontos bastante relevantes, face à regulação tradicional e, ainda, atual das contratações de transferência de tecnologia, conforme analisamos no Capítulo II.

\footnotetext{
398 Isso porque a Nota 3 do Acordo TRIPS define "proteção" como incluindo assuntos relativos à disponibilidade, aquisição, escopo, manutenção e execução dos direitos de propriedade intelectual bem como matérias que afetem o uso da propriedade intelectual e que estejam especificamente mencionadas no acordo. Também o art. 63.1 do TRIPS lista a prevenção do abuso de direitos de propriedade intelectual como matéria afeita ao TRIPS. Vide: NGUYEN, T. T. The CFI's Ruling in Microsoft v. Commission, p. 564.

${ }^{399}$ Conforme Barbosa, relatando o jogo de interesses das negociações: "As penas do direito antitruste estariam reservadas às limitações da concorrência [...]. Para os países em desenvolvimento, a idéia de abuso econômico era outra. Os países do Terceiro Mundo propunham que as restrições resultantes do comércio de tecnologia não fossem consideradas pelo ângulo estrito das limitações à concorrência, mas sim do ponto de vista da proteção e do desenvolvimento da indústria nacional, seja com o auxílio, seja a despeito da concorrência. O segundo ponto de conflito que tolheu o Código foi a situação especial que os países desenvolvidos de economia de mercado (o então chamado grupo B) entendiam haver e os países desenvolvidos da economia de mercado (o então chamado grupo dos 77) recusavam existir no tocante às restrições impostas entre matriz ou controladora e subsidiária ou filial. O raciocínio do Grupo B era de que é impossível conceber restrição à concorrência no caso de empresas sob o mesmo poder de controle. Os países em desenvolvimento, porém, consideravam que o uso de sua mão-deobra, de suas matérias-primas, e do seu mercado implicava, necessariamente, assumir um compromisso perante a comunidade, que superaria o vínculo interno natural do grupo econômico. Assim, as restrições, em princípio inócuas no contexto sem concorrência das empresas sob mesmo controle, seriam inaceitáveis numa análise de interesse social” (BARBOSA, D. B. Uma Introdução à Propriedade Intelectual, p. 154) (grifamos).
} 
Quanto ao fato das medidas terem de ser "apropriadas" e "necessárias" devemos entender a imposição de uma limitação definida negativamente, i.e. remédios claramente excessivos estão excluídos. ${ }^{400}$ No caso da aplicação das leis domésticas de concorrência à tecnologia, o impacto sobre os direitos de propriedade intelectual, sobre o comércio relativo aos direitos de propriedade intelectual e sobre a transferência e disseminação de tecnologia deverá ser analisado nesta medição. Heinemann entende que o termo "apropriadas" refere-se tanto à necessidade de promulgar-se normas específicas nas legislações nacionais como quanto à adoção de medidas para sua repressão e implementação destas normas.

Ponto importante é que tecnologia dentro da moldura do TRIPS refere-se tão somente a tecnologia protegida por propriedade intelectual. ${ }^{401}$ Entre os contratos analisados sob o presente trabalho, o termo, para fins do TRIPS, engloba, portanto, somente tecnologia protegida por segredo de negócio, que seja confidencial. Assim, em não existindo confidencialidade da tecnologia, o TRIPS não se aplica.

As implicações para o desenvolvimento desta opção de regulação de práticas anticompetitivas em contratos, que privilegia fortemente a análise concorrencial - apesar de deixar uma brecha, não difundida e promovida, de regulação de transferência de tecnologia ainda não são claras. Ela deposita grande confiança nas forças de mercado para entregar tecnologia e as vantagens oriundas desta tecnologia aos países em desenvolvimento. Mesmo esse posicionamento ainda reconhece que uma completa ausência de intervenção no mercado é provavelmente incapaz de auxiliar no processo de geração, transferência e difusão de tecnologia aos países em desenvolvimento. ${ }^{402}$

\footnotetext{
${ }^{400}$ Nguyen lembra que os termos "apropriado" e "necessário" nos acordos da OMC geralmente aparecem quando membros recebem a faculdade de impor exceções às obrigações dos acordos. A intenção deve ser a de preservar o equilíbrio entre a liberdade dos membros de determinar e alcançar objetivos regulatórios específicos por meio das medidas que escolherem e desencorajar os membros de adotar e manter medidas que restrinjam o comércio indevidamente (NGUYEN, T. T. The CFI's Ruling in Microsoft v. Commission, p. 565 e ss.).

${ }^{401}$ Capítulo 1, Item 5.

${ }^{402}$ Conforme UNCTAD - United Nations Conference on Trade and Development. Transfer of Technology. United Nations Publication, p. 100. O Relatório entende que os pontos principais desta proposta de regulação pelo TRIPS são: (i) uma reafirmação forte dos direitos de propriedade intelectual do detentor da tecnologia, que só poderão ser constritos baseado em exaustão dos direitos, licença compulsória e preocupações de cunho de saúde pública ou ambiental; (ii) regulação baseada somente em questões relacionadas à concorrência tratando de assegurar que o recipiente da tecnologia atua em situação de concorrência, não indevidamente restrita pelo fornecedor da tecnologia, e que terceiros mantenham sua posição competitiva, evitando-se que o fornecedor de tecnologia utilize sua posição de dominância para criar barreiras à entrada, especialmente por meio de criação de redes de acordos de tecnologia com receptores específicos; (iii) proibição de instituição de critérios de performance relacionados à tecnologia, a menos que sujeitos a considerações de cunho concorrencial; (iv) reconhecimento que o mercado internacional de tecnologia pode agir contra os interesses dos países em desenvolvimento, fazendo-se necessário impor-se certas obrigações às empresas transnacionais e seus governos quanto à geração, transferência e difusão de tecnologia aos países em desenvolvimento, referidas obrigações
} 
Entendemos que as questões comerciais podem e devem focar a promoção da transferência de tecnologia internacional, mas elas jamais conseguirão dar conta da questão da absorção da tecnologia pela mão-de-obra local. Seu foco é outro.

\section{A Regulação Administrativa dos Contratos de Transferência de Tecnologia sob a Perspectiva Concorrencial na Europa, sob o Tratado de Roma}

Analisaremos o tratamento concedido às operações de transferência de tecnologia em território europeu a fim de poder utilizá-lo como parâmetro de comparação e de influência para o delineamento de uma regulação brasileira. Tendo aderido ao TRIPS, os paísesmembros da Comunidade Européia ficam sujeitos às restrições aos contratos de licença por ele impostas. Logo, a regulação no âmbito dos artigos 81 e 82 do Tratado de Roma deverá estar conforme as disposição delineadas no TRIPS. Não nos esqueçamos, entretanto, que a situação e realidade fáticas daquele espaço geográfico é diferente do nosso; que, portanto, as exceções previstas no TRIPS em relação a países em desenvolvimento não se estendem aos países que integram a Comunidade Européia.

Vale ressaltar, ainda, que a regulação européia pauta-se sempre na preservação do livre mercado entre os Estados-membros, corolário dos pilares de livre movimentação de pessoas, mercadorias e serviços dentro do território europeu.

No âmbito europeu, contratos de licença devem ser analisados sob a égide do art. 81 do Tratado de Roma. O inciso 1 proíbe acordos entre empresas e práticas concertadas que sejam suscetíveis de afetar o comércio entre os Estados-Membros e que tenham por objetivo ou efeito impedir, restringir ou falsear a concorrência no mercado comum. Pré-condição para a aplicação do art. 81, inciso 1 , é a existência de uma restrição à concorrência, que seja capaz de afetar o comércio entre os Estados membros da União Européia e que seja identificável. A restrição à concorrência pressupõe que a limitação seja capaz de alterar as condições de

devem revestir-se de recomendações vinculantes ou não-vinculantes e exortações às empresas e/ou seus governos; (v) reconhecimento da posição especial dos países em desenvolvimento em relação ao impacto da proteção integral dos direitos de propriedade intelectual em suas economias, mediante a inclusão de cláusulas de transição com exceções temporais. 
mercado. Assim, compara-se a situação de concorrência antes da restrição e após a restrição. ${ }^{403}$

Para contratos de licença, desenvolveu-se o entendimento em âmbito europeu que o limite do ilícito está no exercício do direito de propriedade intelectual além do interesse protegido pelas faculdades conferidas pelo círculo de exclusões dos direitos de propriedade intelectual. Ocorrerá uma ponderação, em concreto, entre: (i) o âmbito de proteção concedido pelo direito e (ii) o contexto do mercado em que o direito é exercido. Cláusulas relativas a confidencialidade, auxílio do licenciado ao licenciante na defesa dos seus direitos, utilização da marca do licenciante no produto licenciado, pagamentos mínimos e quantidades mínimas de produção são geralmente entendidas como não representativas de limitação à concorrência. ${ }^{404}$ Cláusulas típicas de restrição à concorrência são reconhecidas no caso de fixação de preços, proibição de questionamento da validade do direito pelo licenciado, proibições à exportação e re-importação bem como restrições de quantidade de venda e territoriais.

A análise concorrencial no âmbito do Tratado de Roma refere-se tão somente ao comércio e tráfego de bens entre os Estados membros, não ao comércio entre um paísmembro e um país externo. ${ }^{405}$

Qualquer alteração no comércio entre Estados-membros: seja impedimento, limitação, também a ampliação, do comércio é analisada. Uma prova da efetiva alteração no comércio não precisa ser efetuada. Existem critérios que a pressupõem. Conforme a Diretriz específica editada pela Comissão Européia, há uma presunção de interferência no comércio entre membros quando o faturamento anual das partes com as mercadorias objeto da licença ultrapassar 40 (quarenta milhões de Euros) ${ }^{406}$ e a participação conjunta das partes no mercado relevante dentro da comunidade européia ultrapassar $5 \%$ (cinco por cento). ${ }^{407}$ Caso ainda não exista um mercado relevante que deva ser restringido pelo acordo entre as partes, foca-se no

\footnotetext{
${ }^{403}$ Vide: Diretriz da Comissão Européia sobre a Aplicação do art. 81 a Acordos de Transferência de Tecnologia - Diário Oficial 2004 C 101 2, p. 28 e ss. Especificamente: nota de margem 11.

${ }^{404}$ Vide: Diretriz da Comissão Européia sobre a Aplicação do art. 81 a Acordos de Transferência de Tecnologia. Especificamente: nota de margem 155; LUBITZ, M.; HASSELBLATT, G. (Hrsg.) Münchener Anwaltshanbuch Gewerblicher Rechtsschutz, p. 2015.

${ }^{405}$ Nesta hipótese, aplicar-se-ia o direito concorrencial nacional de cada país, a fim de verificar os efeitos anticoncorrenciais produzidos somente em seu território.

${ }^{406}$ Diretriz da Comissão Européia sobre a questão da interferência do comércio entre Estados-membros nos arts. 81 e 82 do Tratado de Roma, Diário oficial 2004 C 101. O cálculo deve ser feito somando-se o faturamento do licenciado com os produtos da técnica licenciada e do licenciante com estas mercadorias.

${ }^{407}$ A Diretriz não é vinculante para os tribunais.
} 
posicionamento das partes em mercados similares ${ }^{408}$ e suas forças em relação à tecnologia objeto do acordo.

Quanto à capacidade de alterar as condições do mercado, as restrições devem ser relevantes. A Comissão Européia emitiu comunicado sobre a relevância das restrições. ${ }^{409}$ Conforme a comunicação, haverá relevância quando (i) determinados níveis de participação no mercado pelas partes estiverem presentes, ${ }^{410}$ (ii) as restrições forem explícitas ou centrais. Ademais, expõe que acordos entre empresas de médio e pequeno porte raramente têm a possibilidade de influir no comércio entre Estados-membros de forma relevante. ${ }^{411}$

Ainda que preencha todos os requisitos do critério de relevância acima descritos, a restrição pode ser isenta de aplicação das regras concorrenciais por meio de um regulamento de isenção por categoria, que reconhece a aplicação do art. 81, inciso 3, do Tratado de Roma a determinadas categorias de acordos. $\mathrm{O}$ inciso 3 do art. 81 isenta a aplicação do inciso 1 a acordos que contribuam para melhorar a produção ou a distribuição dos produtos ou para promover o progresso técnico ou econômico, contanto que aos utilizadores se reserve uma parte equitativa do lucro daí resultante, e que: a) não imponham às empresas em causa qualquer restrição que não sejam indispensáveis à consecução desses objetivos; b) Nem dêem a essas empresas a possibilidade de eliminar a concorrência em relação a parte substancial dos produtos em causa.

Regulamentos de isenção por categoria têm força de lei e são vinculantes. $O$ regulamento de isenção por categoria aplicável para contratos de transferência de tecnologia parte do pressuposto de que o licenciamento tem efeitos positivos para a concorrência, por promover a circulação da invenção e a maximização de sua utilização.

Especificamente em relação à transferência de tecnologia, são interessantes para análise dois regulamentos de isenção por categoria. O Regulamento 240/96 $6^{412}$ e o Regulamento $772 / 04^{413}$, que o substituiu. ${ }^{414}$ A geração anterior de regulamentos por isenção

\footnotetext{
${ }^{408}$ O termo utilizado em alemão é "benachbarten Märkten".

409 "Bagatellbekanntmachung” Diário Oficial da Comunidade Européia 2001 C 368 p. 13 e ss.

${ }^{410}$ Acordos verticais: $15 \%$; acordos horizontais: $10 \%$ a serem verificados em todos os mercados afetados.

${ }^{411}$ São assim classificados: (i) empresas com menos do que 250 empregados e com faturamento anual inferior a 50 milhões de Euros ou cuja soma do balanço anual ultrapasse 43 milhões de Euros. Nenhum dos sócios deverá deter mais do que $25 \%$ do capital ou do direito de voto (podendo ser maior em determinadas categorias de investidores) e referido sócio não poderá ser, por sua vez, considerado uma empresa de pequeno e médio porte.

${ }^{412}$ Diário Oficial 1996 L 312.

${ }^{413}$ Diário Oficial 2004 L 12311.
} 
especificava um rol de cláusulas proibidas e permitidas em contratos. Dividiam-se as cláusulas em pretas (i.e. proibidas), brancas (i.e. permitidas) e cinzas (i.e. aprovação sujeita à análise da Comissão Européia, se não ocorresse dentro de determinado prazo estaria liberada). A fim de aprovar-se uma cláusula preta ou que não estivesse prevista no regulamento, fazia-se necessário um processo individual de aprovação perante a Comissão Européia.

A nova geração de regulamento de isenção por categoria, diferentemente da anterior, estipula que desde que determinados critérios de participação no mercado não forem ultrapassados, categorias de acordos estão liberadas da proibição concorrencial. Somente algumas cláusulas expressamente previstas no regulamento são proibidas, independentemente da participação de mercado da empresa. Logo, cláusulas não mencionadas no regulamento estão liberadas.

A intenção do regulamento de isenção por categoria é justamente esta, permitir às partes concluir contratos de transferência de tecnologia com relativa segurança quanto à aceitabilidade de suas cláusulas sob o ponto de vista concorrencial. Trata-se de conseguir segurança e previsibilidade para as contratações. Essas contratações recebem atenção especial por meio de um regulamento de isenção por categoria, pois se reconhece seu potencial para promover a difusão dos conhecimentos técnicos no território europeu, incentivando a produção de produtos aperfeiçoados tecnicamente, maximizando os efeitos da inovação . ${ }^{415}$

Acordos de transferência de tecnologia não cobertos pelo Regulamento 772/04 ficam sujeitos à análise individualizada pela Comissão Européia. Este seria o caso para acordos em que a participação de mercado das partes contratuais seja superior à prevista no Regulamento e casos em que o acordo envolva mais de duas partes. ${ }^{416}$

\footnotetext{
${ }^{414}$ Ambos são regulamentos especificamente relacionados a acordos de transferência de tecnologia. Outros regulamentos também poderão ser aplicáveis aos contratos, tais como o Regulamento sobre acordos de especialização (Diário Oficial 2000 L 304 3), o regulamentos sobre acordos de pesquisa e desenvolvimento (Diário Oficial 2000 L 304 7) e o regulamento sobre restrições verticais (Diário Oficial 1999 L 336 21). Cada Regulamento indica participações de mercado e disposições diferentes, que devem ser analisadas caso a caso. A fim de se delimitar qual o Regulamento aplicável, deve-se focar no objeto principal do contrato/acordo. Em sendo o objeto principal a licença, aplica-se os Regulamentos 240/96 e 772/04. Para o presente trabalho, restringiremo-nos à análise dos Regulamentos 240/96 e 772/04, específicos em relação ao contrato de transferência de tecnologia.

${ }^{415}$ Vide: ALTIN-SIEBER, I. Joint Ventures, Technologietransfer und - schutz1996, p. 328 (referindo-se ao Regulamento 240/96), e PIILOLA, A.; DOLMANS, M. The Proposed New Technology Transfer Block Exemption. World Competition 2003 26(4), p. 541.

${ }^{416}$ A Comissão Européia utilizar-se-á analogicamente dos princípios dispostos no Regulamento 772/04 para estes acordos, conforme disposto nas Diretrizes para aplicação do art. 81 do Tratado de Roma para acordos de transferência de tecnologia (nota de margem 40).
} 
Independente da análise sob o art. 81 do Tratado de Roma, aplica-se, ainda, o art. 82 sobre abuso de posição dominante capaz de afetar o comércio entre os Estados-membros. Conforme o art. 82:

É incompatível com o mercado comum e proibido, na medida em que tal seja susceptível de afectar o comércio entre os Estados-Membros, o facto de uma ou mais empresas explorarem de forma abusiva uma posição dominante no mercado comum ou numa parte substancial deste.

Estas práticas abusivas podem, nomeadamente, consistir em:

a) Impor, de forma directa ou indirecta, preços de compra ou de venda ou outras condições de transacção não equitativas;

b) Limitar a produção, a distribuição ou o desenvolvimento técnico em prejuízo dos consumidores;

c) Aplicar, relativamente a parceiros comerciais, condições desiguais no caso de prestações equivalentes colocando-os, por esse facto, em desvantagem na concorrência;

d) Subordinar a celebração de contratos à aceitação, por parte dos outros contraentes, de prestações suplementares que, pela sua natureza ou de acordo com os usos comerciais, não têm ligação com o objecto desses contratos.

Ao contrário do art. 81, que pressupõe a existência de um acordo, o art. 82 trata de condutas unilaterais. Os arts. 81 e 82 têm aplicação paralela. Mesmo que ocorra uma liberação de uma conduta sob o art. 81, inciso 3, e um regulamento de isenção de grupo, o art. 82 poderá ser aplicável. Possui uma posição dominante aquele que não está exposto a concorrência efetiva e, assim, tem a possibilidade de determinar o seu comportamento de mercado independentemente dos outros concorrentes e de seus clientes. Assim, por exemplo, pelo art. 82 o licenciante não poderá discriminar as condições de licença entre diferentes licenciados e não poderá exigir taxas de licença excessivamente altas. ${ }^{417}$ Conforme a jurisprudência da Corte Européia de Justiça, o art. 82 embasa a determinação de licenciamento compulsório. ${ }^{418}$

A conseqüência de um ilícito concorrencial será a imposição de multas, imposição de reparação de danos e/ou de obrigação de não fazer, mas, a mais importante é a nulidade do acordo contrário à concorrência. Haverá uma averiguação pelo juízo sobre se se trata de nulidade integral do acordo, de parte ou, ainda, de cláusula deste. ${ }^{419}$

\footnotetext{
${ }^{417}$ Lubitz; M. HASSELBLATT, G. (Hrsg.) Münchener Anwaltshanbuch Gewerblicher Rechtsschutz, p. 2022.

${ }^{418}$ Vide os seguintes julgados: IMS / NDC EuGH Slg. 1995 I, 743; Magill EuGH Slg. 19886211.

${ }^{419}$ Conforme Lubitz as disposições dos direitos nacionais dos Estados-membros sobre validade dos contratos e atos aplicam-se subsidiariamente na determinação das conseqüências (HASSELBLATT, G. (Hrsg.) Münchener Anwaltshanbuch Gewerblicher Rechtsschutz, p. 2022 e ss.).
} 


\subsection{Regulamento $240 / 96$}

Esse Regulamento refere-se a contratos de know-how e de patentes. Em relação aos regulamentos que lhe foram anteriores, ${ }^{420}$ é mais condescendente com os acordos de transferência de tecnologia, por reconhecer neles efeitos pró-competitivos. ${ }^{421}$

Não possui qualquer critério de participação mínima de mercado. Ele dispõe de lista de cláusulas que representam práticas restritivas em contratos, classificando-as em (i) cláusulas às quais não se aplica o inc. 1 do art. 81, por se considerar preenchidos os requisitos do inc. 3 desse artigo (art. $1^{\circ}$ do Regulamento 240/96); (ii) cláusulas "em geral não restritivas da concorrência" (art. $2^{\circ}$ do Regulamento 240/96); (iii) cláusulas não sujeitas a qualquer isenção de aplicação do direito concorrencial (art. $3^{\circ}$ do Regulamento 240/96) e (iv) cláusulas sujeitas à análise da Comissão Européia a fim de verificar a possibilidade de isenção de aplicação do direito concorrencial (art. $4^{\circ}$ do Regulamento 240/96). A doutrina acabou por denominar essas cláusulas de: (i) isentas; (ii) brancas; (iii) pretas; e (iv) cinzas, conforme a gravidade que reconhece para cada restrição. Utilizaremos esta classificação nos Itens abaixo.

Uma desvantagem desse Regulamento é o fato de ele prever que qualquer cláusula não especificamente mencionada como livre seja sujeita à revisão individual pela Comissão Européia. Como conseqüência, tem-se um Regulamento repleto de hipóteses de cláusulas, que procuram cobrir toda a miríade de possibilidades de restrições em contratos de licença, a fim de que acordos que contenham essas cláusulas não precisem ser submetidas à análise da comissão. ${ }^{422}$ Melhor teria procedido a Comissão Européia se tivesse estabelecido que cláusulas não expressamente previstas presumem-se isentas. Foi o que acabou ocorrendo no Regulamento seguinte, 772/04.

\footnotetext{
${ }^{420}$ Regulamento 2.349/84 sobre licenças de patentes e o Regulamento 556/89 sobre contratos de know-how. Dolmans, M.; Piilola, A., lembram que regulamentos de isenção por categoria para contratos de licença de patentes e de transferência de tecnologia começaram a ser adotados na Comunidade Européia em meados dos anos 80 (oitenta), logo estes foram os primeiros regulamentos específicos para estas contratações (DOLMANS, M.; PIILOLA, A. The Proposed New Technology Transfer Block Exemption. World Competition 2003 26(4)).

${ }^{421}$ Assafim expõe que o Regulamento 240/96, além de unificar a aplicação das disposições do art. 81 do Tratado de Roma a acordos de licenças de patente e de know-how, baseia-se na "finalidade de fomentar a difusão de conhecimentos técnicos na comunidade e de promover a fabricação de produtos tecnicamente mais elaborados" (ASSAFIM, J. M. A Transferência de Tecnologia no Brasil Aspectos Contratuais e Concorrenciais da Propriedade Industrial, p. 243). O autor ressalta, ainda, que o Regulamento se aplica somente a contratos nos quais esteja pressuposta uma pluralidade de vontades, conforme o art. $5^{\circ}$, acordos que não sejam fruto desta pluralidade ficam eliminados do âmbito de aplicação do Regulamento. Vide p. 245 e 246.

${ }^{422}$ Vide o art. $2^{\circ}$ do Regulamento 240/96, que dispõe sobre cláusulas isentas, conforme item 3.1.4 infra.
} 
Para os contratos de know-how, estabelece a nota de margem 13 do Regulamento 240/96:

(13) Tendo em conta a dificuldade de determinar quando é que o saber-fazer deixa de ser secreto, convém, no que diz respeito aos territórios em que a tecnologia licenciada só abrange o saber-fazer, limitar a um certo período a validade de tais obrigações. Além disso, para garantir suficientes períodos de protecção, convém fixar o início desses períodos a partir da data em que o produto é comercializado pela primeira vez por um dos licenciados no interior da Comunidade.

Esta disposição não foi reproduzida no Regulamento seguinte, 772/04.

\subsubsection{Cláusulas pretas}

Caso a contratação contenha uma cláusula classificada como "preta", o contrato integral deixa de ser sujeito à isenção por categoria e deve ser submetido à aprovação individual pela Comissão. Tratava-se do "princípio do tudo-ou-nada", severamente criticado. $^{423}$

A lista de cláusulas pretas foi consideravelmente diminuída em relação aos regulamentos anteriores, a maioria delas passou a integrar a lista cinza do novo Regulamento. ${ }^{424}$ São exemplos de cláusulas pretas no Regulamento 240/96:

(i) A que limite a faculdade de uma das partes na determinação dos preços, dos componentes de preços ou dos descontos relativos aos produtos objecto de licença;

(ii) Aquela pela qual uma das partes estiver limitada no que diz respeito à concorrência com a outra parte, com empresas a ela ligadas ou com outras empresas situadas no mercado comum nos domínios da investigação e do desenvolvimento, da produção e utilização dos produtos concorrentes e sua distribuição, sem prejuízo da obrigação do licenciado de explorar o melhor possível a tecnologia licenciada e sem prejuízo do direito do licenciante de pôr termo à exclusividade facultada ao licenciado e de cessar a licença dos melhoramentos, caso este inicie tais atividades concorrenciais, e do direito de o licenciante

\footnotetext{
${ }^{423}$ Vide: LUBITZ, M.; HASSELBLATT, G. (Hrsg.) Münchener Anwaltshanbuch Gewerblicher Rechtsschutz, p. 2028.

${ }^{424}$ Regulamento 2.349/84 sobre Licenças de patentes e o Regulamento 556/89 sobre contratos de know-how.
} 
exigir que o licenciado prove que o know-how licenciado não é utilizado para a produção de bens e serviços diferentes dos que são objeto da licença;

(iii) Uma ou ambas as partes forem obrigadas, sem qualquer razão objetivamente justificada, a: a) recusar-se a satisfazer pedidos de consumidores ou de revendedores estabelecidos no seu território respectivo, que comercializariam os produtos noutros territórios do mercado comum; b) restringir a possibilidade dos utilizadores ou dos revendedores comprarem os produtos a outros revendedores no mercado comum e, em particular, de invocarem direitos de propriedade intelectual ou de tomarem medidas que impeçam os consumidores ou os revendedores de se abastecerem fora do território objeto de licença ou de comercializarem nesse território produtos que foram legalmente comercializados no mercado comum pelo licenciante ou com o seu consentimento; ou quando tal decorra de uma prática concertada entre as mesmas; ${ }^{425}$

(iv) As partes já eram fabricantes concorrentes antes da concessão da licença e uma delas se encontre, dentro do mesmo domínio de aplicação técnica ou do mesmo mercado de produtos, sujeita a restrições quanto aos clientes que pode servir, especialmente pela proibição de abastecer certas categorias de consumidores, de utilizar certas formas de distribuição ou, com o objetivo de repartir a clientela, de utilizar certos tipos de acondicionamento dos produtos;

(v) Uma das partes se encontre sujeita a restrições quanto à quantidade dos produtos objeto de licença fabricados ou vendidos ou ao número de operações de exploração da tecnologia licenciada;

(vi) O licenciado é obrigado a ceder ao licenciante, no todo ou em parte, os direitos sobre os melhoramentos ou novas aplicações da tecnologia licenciada;

(vii) O licenciante é obrigado, mesmo por acordos separados ou pela prorrogação automática do período de duração inicial do acordo pela inclusão de eventuais novos melhoramentos, durante um período superior a

a) 5 anos da introdução do produto no mercado comum para licenças de patentes, desde que uma patente paralela continue válida em pelo menos um país-membro e

\footnotetext{
${ }^{425}$ Percebe-se aqui a proibição específica de limitação das importações paralelas.
} 
b) 10 anos a contar da data em que o produto é comercializado pela primeira vez para contratos de know-how a não conceder licenças a outras empresas para a exploração da tecnologia facultada no território concedido, ou uma das partes é obrigada, por um período superior ao acima referido, a não explorar a tecnologia facultada no território da outra parte ou de outros licenciados.

\subsubsection{Cláusulas brancas}

São os tipos de cláusulas contratuais que sempre são aceitos, independente de análise prévia pela Comissão Européia. Enumeradas no art. 2 do Regulamento 240/96, incluem, entre outras:

(i) Obrigações de confidencialidade que sobrevivam ao prazo contratual;

(ii) Restrição ao licenciado de conceder sublicenças e de ceder a licença;

(iii) A obrigação do licenciado de cessar a utilização do know-how que, ao final do período de licença, ainda é secreto;

(iv) A obrigação de retrolicença do licenciado, desde que: a) a licença seja nãoexclusiva no caso de melhorias dissociáveis da tecnologia e b) o licenciante tiver se comprometido a conceder ao licenciado, para suas próprias melhorias, uma licença (i.e. necessidade de reciprocidade);

(v) A obrigação do licenciado de manter níveis mínimos de qualidade e manter especificações técnicas fornecidas pelo licenciante quando da fabricação dos produtos, quando necessários a) para permitir a utilização da técnica sem restrições, b) para assegurar que a produção do licenciado seja correspondente às especificações de qualidade do licenciante;

(vi) A obrigação de informar sobre qualquer violação da tecnologia e de ir a juízo contra esta violação ou auxiliar o licenciante na defesa desta violação; 
(vii) A obrigação por parte do licenciado de continuar a pagar as royalties: a) até o final do acordo, cujos montantes, períodos e métodos tenham sido livremente determinados pelas partes, no caso de o know-how se tornar de domínio público não por ação do licenciante, sem prejuízo do eventual pagamento adicional de uma indenização caso o know-how se torne do domínio público por ação do licenciado em violação do acordo; b) por um período superior ao da duração das patentes licenciadas como forma de facilitar o pagamento; ${ }^{426}$

(viii) A obrigação do licenciado de limitar a exploração da tecnologia licenciada a um ou mais domínios de aplicação técnica cobertos por essa tecnologia, ou a um ou mais mercados dos produtos;

(ix) A obrigação do licenciado de pagar um royalty mínimo ou de fabricar uma quantidade mínima dos produtos objeto da licença ou, ainda, de efetuar um número mínimo de operações de exploração da tecnologia licenciada;

(x) A obrigação do licenciado de não utilizar a tecnologia do licenciante para construir instalações destinadas a terceiros; esta obrigação não prejudica o direito do licenciado aumentar a capacidade das suas instalações ou criar novas instalações para seu uso próprio em condições comerciais normais, incluindo o pagamento do royalties adicionais;

(xi) A obrigação do licenciado de fornecer apenas uma quantidade limitada do produto objeto de licença a um determinado cliente, quando a licença é concedida a fim de fornecer a este último uma segunda fonte de abastecimento no território concedido. Esta disposição é igualmente aplicável quando o cliente é o licenciado e a licença concedida com o objetivo de criar uma segunda fonte de abastecimento prevê que o cliente deve fabricar os produtos objeto de licença ou mandá-los fabricar por um subcontratante;

(xii) A reserva pelo licenciante do direito de invocar os direitos conferidos por uma patente para se opor à exploração da tecnologia pelo licenciado fora do território autorizado; de rescindir o acordo caso o licenciado impugne o caráter secreto ou substancial do know-how licenciado ou a validade, no âmbito do mercado comum, de quaisquer patentes licenciadas pertencentes ao licenciante ou a empresas a ele ligadas;

\footnotetext{
${ }^{426}$ Conforme expõe ASSAFIM, J. M. A Transferência de Tecnologia no Brasil Aspectos Contratuais e Concorrenciais da Propriedade Industrial, p. 249, nota de rodapé 526, os pagamentos efetuados posteriormente à expiração da patente na realidade correspondem a pagamentos por exploração realizada durante seu prazo de validade. Concordamos, posto que houve uma redução do valor do pagamento durante o prazo contratual, o que permitiu o pagamento se estendesse para além do prazo do direito.
} 
(xiii) A reserva pelo licenciante do direito de pôr termo à exclusividade conferida ao licenciado, e do direito de deixar de lhe facultar melhoramentos sempre que o licenciado entre em concorrência, no interior do mercado comum, com o licenciante, com empresas a este ligadas ou com outras empresas situadas no domínio da investigação e do desenvolvimento, da fabricação e utilização de produtos concorrentes e sua distribuição, e a reserva pelo licenciante do direito à prova pelo licenciado de que o know-how facultado não é utilizado para a produção de outros produtos e para a prestação de outros serviços que não os objeto de licença.

\subsubsection{Cláusulas cinza}

Esta categoria de cláusula necessita de submissão de aprovação à Comissão Européia, que será concedida automaticamente caso esta não seja aprovada dentro de 4 (quatro) meses. ${ }^{427}$ Exemplos destas cláusulas são:

(i) cláusulas que obriguem o licenciado, no momento da conclusão do acordo, a aceitar especificações de qualidade ou novas licenças ou a adquirir bens ou serviços que não sejam necessários para assegurar uma exploração tecnicamente correcta da tecnologia licenciada ou para garantir a conformidade da produção do licenciado com os padrões de qualidade respeitados pelo licenciante e outros licenciados;

(ii) cláusulas por meio das quais o licenciado for proibido de contestar a natureza secreta ou substancial do know-how licenciado ou a validade, no âmbito do mercado comum, de quaisquer patentes pertencentes ao licenciante ou a empresas a ele ligadas.

\subsection{4 . Cláusulas isentas}

São isentas da aplicação do art. 85, inciso 1, e consideradas justificadas pelo art. 85 , inciso 3, do Tratado de Roma, ${ }^{428}$ as seguintes cláusulas: ${ }^{429}$

\footnotetext{
${ }^{427}$ Regulamento 240/96, art. 4.

${ }^{428}$ Atualmente art. 81 Inciso 1 e art. 81 Inciso 3 do Tratado de Roma.

${ }^{429}$ Regulamento 240/96, art. $1^{\circ}$.
} 
(i) A obrigação por parte do licenciante de não permitir o uso da tecnologia licenciada no território objeto de licença por outras empresas; enquanto a patente estiver válida nesse território ou, em se tratando de contratos de know-how, por prazo não superior a dez anos a contar da data em que o produto objeto da licença é comercializado pela primeira vez por um dos licenciados no interior da Comunidade Européia;

(ii) A obrigação do licenciante de não explorar ele próprio a tecnologia licenciada no território objeto da licença; enquanto a patente estiver válida nesse território ou, em se tratando de contratos de know-how, por prazo não superior a dez anos a contar da data em que o produto objeto da licença é comercializado pela primeira vez por um dos licenciados no interior da Comunidade Européia;

(iii) A obrigação do licenciado de não explorar a tecnologia licenciada no território do licenciante no mercado comum; enquanto a patente estiver válida nesse território ou, em se tratando de contratos de know-how, por prazo não superior a dez anos a contar da data em que o produto objeto da licença é comercializado pela primeira vez por um dos licenciados no interior da Comunidade Européia;

(iv) A obrigação do licenciado de não fabricar ou utilizar o produto objeto de licença e de não utilizar o processo objeto de licença nos territórios concedidos a outros licenciados no mercado comum; enquanto a patente estiver válida nesse território ou, em se tratando de contratos de know-how, por prazo não superior a dez anos a contar da data em que o produto objeto da licença é comercializado pela primeira vez por um dos licenciados no interior da Comunidade Européia;

(v) A obrigação do licenciado de não praticar uma política ativa de comercialização do produto objeto de licença nos territórios concedidos a outros licenciados no mercado comum e, especialmente, de não fazer publicidade expressamente destinada a esses territórios, de não estabelecer aí qualquer sucursal nem manter qualquer depósito para a distribuição do produto; enquanto a patente estiver válida nesse território ou, em se tratando de contratos de know-how, por prazo não superior a dez anos a contar da data em que o produto objeto da licença é comercializado pela primeira vez por um dos licenciados no interior da Comunidade Européia; 
(vi) A obrigação do licenciado de não comercializar o produto objeto da licença nos territórios concedidos a outros licenciados no mercado comum, em resposta a pedidos de entrega não solicitados, por um período não superior a cinco anos a contar da data em que o produto licenciado foi comercializado pela primeira vez no mercado comum por um dos licenciados, desde que e enquanto, nesses territórios, esse produto for protegido por patentes paralelas;

(vii) A obrigação do licenciado de apenas utilizar a marca de fábrica do licenciante ou a apresentação determinada por este para distinguir o produto objeto de licença durante o período de validade do acordo, desde que o licenciado não seja impedido de indicar que é o fabricante do produto objeto de licença; enquanto a patente estiver válida nesse território ou enquanto o know-how for secreto e substancial;

(viii) A obrigação do licenciado de limitar a sua produção do produto objeto de licença às quantidades necessárias à fabricação dos seus produtos e de vender o produto objeto de licença unicamente como parte integrante ou como peça sobressalente dos seus produtos, ou enquanto ligado de qualquer outro modo à venda dos seus próprios produtos, desde que tais quantidades sejam livremente determinadas pelo licenciado e desde que a patente esteja válida no território aplicável ou o know-how permaneça válido e substancial.

\subsubsection{Críticas e mudanças para o novo Regulamento}

As principais críticas ao Regulamento 240/96 centraram-se no fato de que a classificação das suas cláusulas era muito formalista e rígida. Entendia-se que algumas cláusulas haviam sido incluídas sem justificativa econômica para tanto. Apontava-se para a excessiva rigidez no tratamento a restrições de clientela e cláusulas de não-concorrência (que podem ser necessárias para estimular o licenciado a dedicar recursos necessários para a tecnologia licenciada). Vale lembrar, entretanto, que o Regulamento de isenção por categoria tem a finalidade de constituir um porto seguro, um guia para orientação. Não é necessário cumprir com ele, o recurso à aprovação específica pela Comissão Européia ainda pode ser adotado. 
Critica-se também a ausência de consistência do Regulamento, por tratar muitas cláusulas de efeitos semelhantes à concorrência de forma diferente. Restrições territoriais e restrições de clientela, por exemplo, são tratados de forma diferente no Regulamento 240/96.

O Regulamento 772/04, tem uma moldura mais flexível de cláusulas. Conforme analisaremos abaixo, ela contém um número menor de cláusulas "pretas" e "cinzas", e cláusulas não previstas expressamente no Regulamento estariam isentas de análise concorrencial. As licenças entre competidores estão sujeitas a regras mais estritas no Regulamento 772/04; estreitaram-se ainda mais as regras sobre restrições territoriais.

Em contrapartida, inseriram-se parâmetros máximos de participação no mercado das empresas envolvidas que ensejam o direito a usufruir do regulamento de isenção por categoria.

Argumenta-se que a regulação se tornou mais sofisticada a partir do Regulamento 772/04, com a mescla de critérios de condutas e de quotas de participação de mercado. Ao tornar-se flexível e mais orientada economicamente, a regulação tem o preço de aumentar a complexidade de aplicação. Faz-se necessária uma análise econômica mais sofisticada para aplicar suas regras. ${ }^{430}$ Ao mesmo tempo, permite-se uma maior liberdade contratual para as partes ao definirem as condições de contratação.

\subsection{Regulamento $772 / 04$}

O Regulamento 772/04 aplica-se a contratos relativos a patentes, know-how, desenhos industriais e software, ${ }^{431}$ que se refiram à produção de produtos contratuais. ${ }^{432}$ Conforme o Regulamento 772/04, algumas restrições de negócios presentes nesses contratos

\footnotetext{
${ }^{430}$ Vide: DOLMANS, M.; PIILOLA, A. The Proposed New Technology Transfer Block Exemption, p. 548.

${ }^{431}$ Contratos de licença de marca e de direitos autorais (excluindo-se o software) não são abrangidos por este Regulamento, a menos que estejam incluídos como acordo acessório dentro de um acordo que tenha por objeto principal aqueles especificamente incluídos no Regulamento 772/04.

${ }^{432}$ Excluem-se, assim, contratos sobre pool de patentes e contratos-master, que definem somente as regras para a concessão de sub-licenças dos direitos. Vale ressaltar que produto é definido como: "um bem ou um serviço, incluindo quer os bens e serviços intermédios, quer finais”. Art. $1^{\circ}$ Inciso 1 alínea e.
} 
são eximidas da aplicação do direito concorrencial ${ }^{433}$ desde que presentes determinados pressupostos. Para que as empresas possam se fazer valer do Regulamento é necessário que a participação de ambas as partes contratuais no mercado do produto ou da tecnologia, juntas, não ultrapasse $20 \%$ para empresas concorrentes ${ }^{434}$ e $30 \%$ para empresas não concorrentes. ${ }^{435}$

A crítica da inserção desta participação de mercado no Regulamento 772/04 veio no sentido de que o art. 82 do Tratado de Roma já prevê a análise de abuso de posição dominante e tem prevalência sobre qualquer regulamento de isenção por categoria; que debruçar-se sobre participações de mercado é uma forma de olhar para trás e não para a frente, onde deveria estar o foco no caso de mercados de tecnologia e inovação. Estima-se que o mais relevante nesse mercado não seja quantas empresas atualmente vendem produtos no mercado, mas sim quantas empresas têm o potencial de ameaçar a posição do licenciante. ${ }^{436}$

Certamente aumenta-se a insegurança em relação à aplicação das quotas de mercado, pois que a definição de mercados relevantes em tecnologia é difícil, especialmente em produtos inovadores. ${ }^{437}$

\footnotetext{
${ }^{433}$ Lubitz explicita que às restrições que integram o objeto específico do direito o art. 81 Inciso 3 do Tratado de Roma não se aplica (HASSELBLATT, G. (Hrsg.) Münchener Anwaltshanbuch Gewerblicher Rechtsschutz, p. 2024).

${ }^{434}$ Conforme Art. 1, Inciso 1, Letra j, alíneas i e ii do Regulamento 772/04, são aquelas empresas que estão em posição de concorrência no mercado relevante de tecnologia ou de produto. Em se tratando de mercado de produtos, potenciais concorrentes também se enquadrariam na definição. Mas não em relação ao mercado de tecnologia. Conforme a nota de margem 29 das Diretrizes sobre a aplicação do art. 81, 3 aos acordos de transferência de tecnologia: "As partes são consideradas potenciais competidores no mercado de produto se, na ausência do contrato e sem infringir direitos de propriedade intelectual da outra parte, é provável que elas teriam feito o investimento adicional necessário para entrar no mercado relevante à procura de uma pequena, mas permanente alta de preços nos produtos."

${ }^{435}$ Trata-se de participações mais altas e mais generosas do que a participação definida na comunicação da Comissão Européia sobre a relevância de restrições contratuais (Bagatellbekanntmachung): acordos verticais: $15 \%$; acordos horizontais: $10 \%$, a ser verificada em todos os mercados afetados.

${ }^{436}$ DOLMANS, M.; PIILOLA, A. The Proposed New Technology Transfer Block Exemption, p. 553, mencionam que as Diretrizes americanas de 1995 têm uma aproximação melhor em relação ao mercado de tecnologia. O problema torna-se duplo pelo fato de a Comissão Européia se propor a analisar o percentual de mercado e dois mercados diferentes: o de produto (i.e. o mercado do produto que será substituído ou melhorado pela tecnologia licenciada) e o de tecnologia (i.e. o mercado para a tecnologia no qual a tecnologia licenciada compete. A própria Comissão Européia reconheceu a dificuldade de se definir os mercados e de calcular os percentuais de participação. A fim de calcular a participação de mercado em mercado de tecnologia a Comissão se propõe a utilizar as participações no mercado de produtos como base. Assim, parte-se de todas as vendas de produtos que incorporam a tecnologia relevante e posteriores na cadeia produtiva.

${ }^{437}$ Conforme a extensa regulamentação nas Diretrizes sobre a aplicação do art. 81, 3 aos acordos de transferência de tecnologia: "Nota de margem 20 - A tecnologia é um factor que está integrado quer num produto quer num processo de produção. A concessão de licenças de tecnologia pode, por conseguinte, afectar a concorrência tanto no mercado dos factores de produção, como no mercado da produção propriamente dita. Por exemplo, um acordo entre duas partes que vendem produtos concorrentes e que se concedem mutuamente as licenças respectivas para as tecnologias relativas ao fabrico desses produtos pode restringir a concorrência no mercado do produto relevante. Pode igualmente restringir a concorrência no mercado das tecnologias e eventualmente também noutros mercados de factores de produção. Para apreciar os efeitos de acordos de licença sobre a concorrência, pode por conseguinte -ser necessário definir o mercado relevante dos bens e serviços (mercado do
} 
produto), bem como o mercado da tecnologia. A expressão «mercado do produto» utilizada no artigo 3.o do RICTT refere-se aos mercados dos bens e serviços relevantes nas suas dimensões geográfica e de produto. Tal como decorre claramente do n.o 1, alínea j), do artigo 1.o do RICTT, a expressão é utilizada apenas para estabelecer uma distinção entre o mercado dos bens e serviços relevante e o mercado da tecnologia relevante.

Nota de margem 21 - O RICTT e as presentes orientações dizem respeito aos efeitos nos mercados dos produtos finais e dos produtos intermédios. $\mathrm{O}$ mercado do produto relevante inclui produtos considerados pelos compradores como intersubstituíveis ou substituíveis em relação aos produtos contratuais que integram a tecnologia licenciada, devido às características dos produtos, aos seus preços e à utilização pretendida.

Nota de margem 22 - O mercado da tecnologia inclui a tecnologia licenciada e os seus substitutos, ou seja, outras tecnologias que são consideradas pelos licenciados como intersubstituíveis ou substituíveis em relação à tecnologia licenciada, devido às características das tecnologias, às suas royalties e à utilização pretendida. $\mathrm{O}$ método utilizado para definir o mercado da tecnologia assenta nos mesmos princípios que o utilizado para definir o mercado do produto. A partir da tecnologia comercializada pelo licenciante, é conveniente identificar as outras tecnologias que os licenciados poderão passar a utilizar em reacção a um aumento ligeiro mas permanente dos preços relativos, isto é, das royalties. Uma outra abordagem consiste em considerar os produtos que incorporam a tecnologia licenciada (ver ponto 23 ).

Nota de margem 23 - Após a definição dos mercados relevantes, é conveniente atribuir quotas de mercado às diferentes fontes de concorrência que nele operam e que são utilizadas como indicador do poder relativo dos diferentes operadores. No caso dos mercados da tecnologia, uma forma de proceder consiste em calcular quotas de mercado com base na parte de cada tecnologia nas receitas totais constituí- das pelas royalties, que representam uma quota da tecnologia no mercado em que diferentes tecnologias concorrentes são licenciadas. Contudo, isto pode frequentemente ser uma simples forma teórica e não muito prática de proceder, devido à falta de informações claras sobre as royalties, etc. Uma abordagem alternativa, a utilizada no n.o 3 do artigo 3.o do RICTT, consiste em calcular as quotas de mercado no mercado da tecnologia com base nas vendas de produtos que incorporam a tecnologia licenciada nos mercados do produto a jusante (ver ponto 70). Nesta abordagem, todas as vendas no mercado do produto relevante são tomadas em consideração, independentemente do facto de o produto incorporar uma tecnologia licenciada. No caso dos mercados da tecnologia, justifica-se a abordagem do n.o 3 do artigo 3.o, a fim de tomar em consideração tecnologias que são (apenas) utilizadas internamente. Na realidade, esta abordagem é geralmente um bom indicador da relevância da tecnologia. Em primeiro lugar, considera qualquer concorrência potencial de empresas que fabricam os produtos com a sua própria tecnologia e que são susceptíveis de começar a licenciá-la em reacção a um ligeiro mas permanente aumento do preço das licenças. Em segundo lugar, mesmo que seja pouco provável que outros titulares da tecnologia comecem a licenciá-la, o licenciante não tem necessariamente poder no mercado da tecnologia, ainda que obtenha uma parte elevada das receitas de licenças. Se o mercado do produto situado a jusante for competitivo, a concorrência que se exerce a esse nível pode efectivamente limitar o licenciante. Um aumento das royalties a montante afecta os custos do licenciado, o que o torna menos competitivo e lhe faz perder vendas. A parte detida por uma tecnologia num mercado do produto reflecte igualmente este elemento e constitui, por conseguinte, normalmente um bom indicador do poder de mercado do licenciante. Em casos individuais não abrangidos pela zona de protecção proporcionada pelo RICTT, pode revelar-se necessário, quando for possível na prática, aplicar as duas abordagens anteriormente referidas, a fim de apreciar com mais exactidão o poder de mercado do licenciante.

Nota de margem 24 - Além disso, fora da zona de protecção proporcionada pelo RICTT, deve ser igualmente tomado em considera- ção, que a quota de mercado pode nem sempre constituir uma indicação correcta do poder relativo das tecnologias disponíveis. Por conseguinte, a Comissão terá também em conta, nomeadamente, o número de tecnologias disponíveis controladas independentemente, para além das tecnologias controladas pelas partes no acordo, susceptíveis de serem substituíveis em relação à tecnologia licenciada a custos comparáveis para o utilizador (ver ponto 131).

Nota de margem 25 - Certos acordos de licença podem afectar os mercados da inovação. Contudo, quando a Comissão analisa estes efeitos, limita-se normalmente a examinar o impacto do acordo sobre a concorrência nos mercados do produto e da tecnologia existentes. A concorrência nesses mercados pode ser afectada por acordos que atrasam a introdução de produtos melhorados ou de novos produtos que, a prazo, substituirão os produtos existentes. Nesse caso, a inovação constitui uma fonte de concorrência potencial que deve ser tomada em consideração aquando da apreciação do impacto do acordo no mercado do produto e no mercado da tecnologia. Todavia, num número limitado de casos, pode ser útil e necessário definir também os mercados da inovação. É nomeadamente o que acontece quando o acordo afecta a inovação destinada a criar novos produtos e quando é possível determinar muito cedo os pólos de investigação e desenvolvimento. Pode então determinar-se se, após o acordo, se manterá um número de pólos de investigação e desenvolvimento competitivos suficiente para que uma concorrência efectiva se mantenha no domínio da inovação." 
Ullrich entende que o Regulamento 772/04 reflete uma tendência generalizada de permitir, se não incentivar, inovação dentro de grupos empresariais e uma tendência próinovação na análise das operações de licença. ${ }^{438}$ Conforme o Relatório da Comissão Européia sobre a Avaliação da Transferência de Tecnologia:

\begin{abstract}
Ao rever as regras atuais e conceber um futuro regime, é preciso levar em consideração que a inovação em novos produtos e novas tecnologias é a última fonte de concorrência substancial e efetiva ao longo do tempo. A ênfase indevida na eficiência alocativa de curto prazo poderá, portanto, criar uma troca desfavorável socialmente entre a eficiência estática e a dinâmica. ${ }^{439}$
\end{abstract}

Trata-se de uma mudança radical, que representa uma passo adicional na direção da reformulação geral das regras de concorrência pela Comissão Européia, ${ }^{440}$ que abandona o foco típico no exercício territorial dos direitos de propriedade intelectual. Licenças verticais são tratadas muito similarmente a restrições verticais, licenças horizontais são tratadas de forma análoga às restrições horizontais.

No caso de contratos de know-how, a isenção do Regulamento 772/04 se aplica somente enquanto este permanecer secreto. ${ }^{441}$ Para os outros direitos, desde que respeitado o prazo de duração do Regulamento $772 / 04,{ }^{442}$ o prazo do acordo poderá perdurar enquanto subsistir o direito de propriedade intelectual. Há, ainda, a exigência de que o know-how seja substancial, ou seja, importante e útil para a manufatura do produto contratual. ${ }^{443}$

\title{
3.2.1. Restrições graves
}

Conforme o art. 4 do Regulamento 772/04, a presença de uma ou mais restrições graves em um acordo isentam-no da aplicação do Regulamento. Faz-se necessário o recurso ao procedimento de aprovação individual pela comissão, conforme o art. 81 , inciso 3 , do

\footnotetext{
${ }^{438}$ ULLRICH, H. Expansionist Intellectual Property Protection and Reductionist Competition Rules: a TRIPS Perspective, p. 748 e ss.

${ }^{439}$ Diário Oficial 2001 C 786 nota de margem 190.

${ }^{440}$ Conforme a Diretiva 1/2003, regulamentos de isenção em bloco não validam restrições inválidas em práticas negociais. Estas são inválidas por força do art. 81 Inciso 3. O Regulamento as protege de uma declaração posterior de nulidade.

${ }^{441}$ A menos que tenha se tornado público por ato imputável ao licenciado, em qual caso a restrição permanece válida pelo prazo originalmente acordado, em relação a aquele licenciado específico (art. 2 do Regulamento $772 / 04)$.

${ }^{442} 30 / 04 / 2014$ (art. 11 do Regulamento 772/04)

${ }^{443}$ Regulamento $772 / 04$, art. $1^{\circ}$ Inciso 1 alínea i (ii).
} 
Tratado de Roma. Referidas restrições graves são definidas no Regulamento 772/04 em função de ser o acordo (i) entre concorrentes ou (ii) entre empresas não concorrentes.

\subsubsection{Entre empresas concorrentes}

(i) Fixação de preços ${ }^{444}$

A fixação de preços de revenda aplica-se tanto a preços de produtos que incorporam a tecnologia como a preços de outros produtos vendidos pelas partes, independente do fato de esses outros produtos também estarem em relação de concorrência ou não. Sob esta categoria enquadram-se preços fixos, preços mínimos, preços máximos e sugestões de preços. Também a obrigação do licenciado de conceder somente determinada categoria de desconto ou de não oferecer preços abaixo dos praticados pelo licenciante é considerada fixação de preço para fins desse artigo do Regulamento 772/04. As Diretrizes definem que uma fixação indireta de preços ocorrerá, também, quando os valores das taxas de licença aumentarem após o alcance de determinado limite de preços dos produtos. Já a fixação de taxas mínimas de licença a serem pagas pelo licenciado não se enquadram nesta definição. ${ }^{445}$

\section{(ii) Limitação de produção}

Qualquer espécie de limitação de produção do licenciado pelo licenciante é considerada restrição grave, a menos que se refira a produtos fabricados com a tecnologia licenciada. Nesse caso, restrições de produção ou de comercialização são permitidas.

(iii) Indicação/divisão de mercados ou clientes

\footnotetext{
${ }^{444}$ Regulamento 772/04, art. 4 Inciso 1 Alínea a.

${ }^{445}$ Diretrizes sobre a aplicação do art. 81, 3 aos acordos de transferência de tecnologia, nota de margem 79.
} 
Apesar de prevista uma como restrição grave, diversas exceções são possíveis. Por exemplo, cláusulas de escopo de uso em determinados mercados de produtos ou aplicações são permitidas.

Nesta restrição é relevante diferenciar-se entre partes de contratos recíprocos ou não. Havendo reciprocidade, a Comissão Européia entende o acordo como mais potencialmente danoso e, portanto, impõe restrições maiores. A licença cruzada não implica necessariamente em reciprocidade. Uma licença será considerada não-recíproca quando for unilateral e também quando a reciprocidade referir-se a tecnologias não-concorrentes e que não sirvam para a produção de produtos concorrentes. ${ }^{446}$ Caso partes em contratos nãorecíprocos celebrem mais tarde uma outra licença que implica a reciprocidade, a primeira deverá adequar-se ao novo padrão.

Em não estando em relação de reciprocidade, as empresas poderão comprometerse a não atuar em determinados ramos de aplicação da tecnologia, em determinados mercados de produto ou territórios exclusivos reservados à outra parte. Porém, uma restrição genérica, que indique que todas as demais áreas de atuação não expressamente mencionadas no contrato estão reservadas para o licenciante não é válida. É preciso que o licenciante tenha a intenção de atuar, no futuro, nos mercados que exclui do contrato. A fim de não restringir o licenciante de forma muito rígida, uma estratégia de longo prazo que envolva 5 (cinco) a 10 (dez) anos é geralmente considerada como aceitável. ${ }^{447}$ Desde que a restrição de atuação coincida com o território do contrato, e tenha sido estipulada e negociada, não há de se considerar uma restrição indevida do licenciado. Resta claro que as demais áreas de atuação para o produto licenciado serão preenchidas pelo licenciante no futuro.

Somente em contratos não-recíprocos é possível estabelecer a proibição de venda ativa e/ou passiva em territórios exclusivos ou clientes exclusivos da outra parte. Para contratos não-recíprocos, será possível, também, proibir o licenciado de efetuar vendas ativas

\footnotetext{
${ }^{446}$ Diretrizes sobre a aplicação do art. 81, 3 aos acordos de transferência de tecnologia, nota de margem 78 .

${ }^{447}$ Vide: LUBITZ, M.; HASSELBLATT, G. (Hrsg.) Münchener Anwaltshanbuch Gewerblicher Rechtsschutz., p. 2031.
} 
no território exclusivo ou clientela exclusiva de um outro licenciado, mas não vendas

passivas. ${ }^{448}$ E desde que este outro licenciado não seja um concorrente do licenciante.

É possível, também, estabelecer-se que o licenciado deverá utilizar a tecnologia somente para fabricar produtos para uso próprio (i.e. restrição de utilização cativa). Em se tratando de componentes, é possível limitar a utilização de componentes somente pelo licenciado, para montar seus próprios produtos, excluindo a possibilidade de entrega a terceiros. Entretanto, o licenciado deve ter a possibilidade de utilizar os componentes como peça de reposição para seus próprios produtos, vendidos a terceiros, e dessa forma entregá-los a terceiros que prestam serviços pós-venda. ${ }^{449}$

O licenciado também poderá, somente em contratos não recíprocos, estar limitado quanto à destinação do produto, podendo fabricá-lo somente para um cliente, desde que dessa forma se logre obter uma fonte alternativa de abastecimento para esse cliente. Esta restrição poderá ser acordada com diversos licenciados em relação ao mesmo cliente. ${ }^{450}$

\section{(iv) Própria pesquisa do licenciado}

São restrições graves a limitação do licenciado de explorar sua própria tecnologia ou a restrição às partes de empreenderem pesquisa e desenvolvimento. A única exceção é no caso da licença de know-how, quando a ausência desta restrição implicaria a divulgação do know-how terceiros. Para que se aplique a exceção ao contrato de know-how é preciso que não haja qualquer outro meio de impedir a divulgação a terceiros. ${ }^{451}$

\footnotetext{
${ }^{448}$ A venda ativa significa uma abordagem direta ativa dos clientes individuais, a venda passiva significa o fornecimento de encomendas de clientes que não foram procurados diretamente. Vide: LUBITZ, M.; HASSELBLATT, G. (Hrsg.) Münchener Anwaltshanbuch Gewerblicher Rechtsschutz, p. 2033.

${ }^{449}$ Conforme as Diretrizes sobre a aplicação do art. 81, 3 aos acordos de transferência de tecnologia, nota de margem 92, a restrição cativa pode ser necessária para favorecer a divulgação de uma tecnologia entre concorrentes.

${ }^{450}$ Conforme a nota de margem 93 das Diretrizes sobre a aplicação do art. 81, 3 aos acordos de transferência de tecnologia, a possibilidade de tais acordos repartirem mercados é limitada, na medida em que a licença é concedida apenas para efeitos de abastecimento de um determinado cliente. Em especial, nessas circunstâncias, não se pode presumir que o acordo leve o licenciado a deixar de explorar a sua própria tecnologia.

${ }^{451}$ Art. 4, inciso I, alínea d, do Regulamento 772/04.
} 


\subsubsection{Entre empresas não concorrentes}

\section{(i) Limitações de preço}

A determinação direta ou indireta de preços fixos ou de preços mínimos em relação aos produtos vendidos a terceiros pelo licenciado é um restrição grave. O estabelecimento de preços máximos e de sugestões de preço são permitidas.

\section{(ii) Restrições ao território e círculo de clientes do licenciado}

A limitação da venda passiva é considerada uma restrição grave, porém, há diversas exceções que foram delineadas pela Comissão Européia. A restrição de vendas ativas é geralmente aceita. Já a restrição de vendas passivas pelo licenciado é permitida para territórios geográficos ou clientes que o próprio licenciante se reservou. Já em relação à exclusividade de outros licenciados, a restrição de venda passiva somente poderá ser imposta nos dois primeiros anos de exclusividade desse licenciado.

É possível restringir o licenciado para que utilize os produtos somente para uso próprio. Aqui, novamente, como nos contratos entre concorrentes, em se tratando de componentes, é possível limitar a utilização somente para a montagem pelo licenciado de seus próprios produtos, excluindo a possibilidade de entrega a terceiros. Entretanto, o licenciado deve ter a possibilidade de utilizar os componentes como peça de reposição para seus produtos, e dessa forma vendê-los a terceiros que prestam serviços pós-venda.

Da mesma forma que nos contratos entre concorrentes, o licenciado também poderá, somente em contratos não recíprocos, estar limitado quanto à destinação do produto, podendo fabricá-lo somente para um cliente, desde que dessa forma se logre obter uma fonte alternativa de abastecimento para esse cliente. Esta restrição poderá ser acordada com diversos licenciados em relação ao mesmo cliente. Ao licenciante também será possível estabelecer um licenciado como responsável pelo comércio atacadista e proibi-lo de vender diretamente a consumidores finais. 


\section{(iii) Restrições ao território e círculo de clientes do licenciante}

É permitida a venda ativa ou passiva pelo licenciante para território exclusivo ou clientela exclusiva de licenciados, desde que expressamente acordado.

\section{(iv) Venda seletiva}

O licenciante deve ter a capacidade de montar um sistema de vendas seletivas, dentro do qual ele deve poder ter a possibilidade de fazer vendas ativas e passivas a consumidores finais ou a outros membros do sistema. Isto inclui também a possibilidade de atribuir a um licenciado a função de atacadista. Dentro de um sistema de vendas seletivas, o licenciante deve ter a possibilidade de impor restrições de venda ativas e passivas a determinados licenciados não autorizados.

\subsubsection{Restrições excluídas}

Se um acordo contém uma cláusula listada como restrição excluída, somente esta ficará sujeita à aprovação em separado pela Comissão Européia, não o contrato inteiro. ${ }^{452}$

\section{(i) Retrolicença e dever de cessão}

Não são permitidas retrolicenças exclusivas do licenciado ou obrigações ao licenciado de ceder direitos em melhorias próprias e separáveis da tecnologia licenciada ou ceder direitos sobre novas aplicações da tecnologia ao licenciante ou a terceiros indicados pelo licenciante. $\mathrm{O}$ fato destas obrigações serem onerosas é indiferente para o Regulamento

\footnotetext{
${ }^{452}$ Ao contrário das cláusulas graves, que ensejam a submissão de todo o contrato à Comissão Européia.
} 
772/04. ${ }^{453}$ A melhoria será considerada separável da tecnologia licenciada quando puder ser utilizada sem violação da tecnologia original. Já a obrigação de conceder retrolicenças não exclusivas é permitida. O licenciante também poderá ser obrigado a licenciar ao licenciado melhorias na tecnologia.

\section{(ii) Proibição de contestação dos direitos do licenciante em juízo}

Qualquer tipo de cláusula que tente impedir o licenciado de questionar a validade dos direitos de propriedade intelectual do licenciante em juízo é considerada pela Comissão Européia como inibidora de inovação, ao invés de incentivadora. No entanto, a rescisão do contrato nesses casos é considerada válida. Para contratos de know-how, apesar de incomum, a restrição é permitida. ${ }^{454}$

\section{(iii) Restrições à pesquisa e desenvolvimento}

Em se tratando de empresas não concorrentes, a restrição ao licenciado quanto à exploração da própria tecnologia bem como de conduzir pesquisa e desenvolvimento é considerada problemática. A exceção é somente para os casos de contratos de know-how e, mesmo assim, quando for imprescindível para impedir a divulgação de know-how a terceiros.

\footnotetext{
${ }^{453}$ Conforme explicitado por Lubitz o fato de haver uma retribuição monetária relevante para a obrigação é levado em consideração pela Comissão Européia quando da análise individualizada da cláusula pelo art. 81 Inciso 3 do Tratado de Roma. O entendimento é o de em havendo a retribuição justa, o incentivo do licenciado em inovar não será tolhido (HASSELBLATT, G. (Hrsg.) Münchener Anwaltshanbuch Gewerblicher Rechtsschutz, p. 2034).

${ }^{454}$ Vide LUBITZ, M.; HASSELBLATT, G. (Hrsg.) Münchener Anwaltshanbuch Gewerblicher Rechtsschutz, p. 2035. Conforme a nota de margem 112 das Diretrizes sobre a aplicação do art. 81, 3 aos acordos de transferência de tecnologia: "A razão da exclusão das cláusulas de não contestação do âmbito da isenção por categoria $e ́$ facto de os licenciados se encontrarem em geral nas melhores condições para determinar se um direito de propriedade intelectual é ou não inválido. Para evitar qualquer distorção da concorrência e em conformidade com os princípios subjacentes à protecção da propriedade intelectual, os direitos de propriedade intelectual não válidos devem ser eliminados, uma vez que paralisam a inovação em vez de a promoverem. O n.o 1 do artigo 81.o pode igualmente ser aplicável a cláusulas de não contestação, quando a tecnologia licenciada possui um determinado valor e penaliza, por conseguinte, a nível da concorrência, as empresas que não a podem utilizar ou que podem apenas utilizar mediante o pagamento de royalties. Nesse caso, é pouco provável que as condições previstas no n. 3 do artigo 81. se encontrem reunidas. No entanto, a Comissão tem uma posição favorável em relação às cláusulas de não contestação relativas ao saber-fazer, uma vez que se for divulgado pode ser impossível ou muito difícil recuperar o saber-fazer licenciado. Nesses casos, uma obrigação de o licenciado não contestar o saber-fazer licenciado promove a divulgação de nova tecnologia, em especial, permitindo que os licenciantes mais fracos concedam licenças a licenciados mais fortes sem temer contestação depois de o licenciado ter absorvido o saber-fazer" (grifamos).
} 
Novamente, a restrição somente será imprescindível quando não houver outro modo de evitarse a divulgação a terceiros.

\subsection{A Aplicação do Direito Concorrencial pela Comissão Européia}

O último ponto importante a salientar em relação à regulação das práticas restritivas em contratos de transferência de tecnologia no Tratado de Roma é o fato de que a análise concorrencial anterior à produção de efeitos do contrato, bem como a edição de regulamentos, é efetuada pela Comissão Européia. Órgão criado pelo Tratado de Roma, o art. 211, que regula sua instituição e atividades deixa claro que a ela compete:

\footnotetext{
Artigo 211.

A fim de garantir o funcionamento e o desenvolvimento do mercado comum, a Comissão:

- vela pela aplicação das disposições do presente Tratado bem como das medidas tomadas pelas instituições, por força deste,

- formula recomendações ou pareceres sobre as matérias que são objecto do presente Tratado, quando este o preveja expressamente ou quando tal seja por ela considerado necessário,

- dispõe de poder de decisão próprio, participando na formação dos actos do Conselho e do Parlamento Europeu, nas condições previstas no presente Tratado, - exerce a competência que o Conselho lhe atribua para a execução das regras por ele estabelecidas.
}

Assim, não se trata de órgão exclusivo de aplicação da regras da concorrência presentes no Tratado de Roma, mas sim de órgão que zela pela aplicação do Tratado de Roma como um todo. A Comissão Européia tratará da emissão de diretivas e normativos em todas as áreas do direito europeu. Não há, portanto, um órgão no âmbito da comunidade econômica européia encarregado exclusivamente de tratar da matéria concorrencial do direito comunitário. Entendemos que esse fato sinaliza a própria natureza instrumental da defesa da concorrência no mercado comum europeu e no direito comunitário europeu. 


\section{Direito da Concorrência e da Propriedade Industrial como Instrumento de Política Pública na Revisão dos Contratos de Transferência de Tecnologia no Brasil}

\subsection{A Aplicação de Disposições do Direito Concorrencial a Contratos de Transferência de Tecnologia pelo INPI}

A Lei 5.772/71 continha disposições específicas sobre cláusulas que não deveriam constar de contratos de exploração de patentes e de licença de uso de marcas, muitas delas aludindo a questões de cunho concorrencial, como por exemplo a proibição de cláusulas de limitação de território, incluindo limitação de exportações, da parte licenciada. ${ }^{455}$ A existência destas cláusulas nos contratos ensejavam a sua não registrabilidade. Para contratos de transferência de tecnologia no sentido deste trabalho, disposições relativas a cláusulas contratuais e o direito concorrencial só vieram a ser normatizadas com a edição do Ato Normativo $15 / 75.456$

Conforme a classificação das operações de transferência de tecnologia constantes de referido Ato Normativo 15/75, as categorias abrangidas pelos contratos de transferência de tecnologia objeto desta tese seriam as de (i) fornecimento de tecnologia industrial ${ }^{457}$, (ii) cooperação técnico industrial ${ }^{458}$ e (iii) serviços técnicos especializados ${ }^{459}$. Cada uma das seções respectivas do AN 15/75 contém dispositivos semelhantes quanto à aplicação da legislação concorrencial. Exemplificativamente, dispõe o Item 4.5.2:

\footnotetext{
${ }^{455}$ Vide arts. 29 e 30 e também 90 da Lei 5.772/71, dispondo sobre a proibição de restrições à industrialização e comercialização dos produtos e serviços, incluindo restrições à exportação.

${ }^{456}$ Referimo-nos à nossa análise da capacidade normativa da Administração Pública empreendida no Capítulo II, Item 2.5. Para outras questões relativas ao Ato Normativo 15/75, referimo-nos também ao Item 2.5 do Capítulo II.

${ }^{457}$ AN 15/75 Item 4.1: "Considera-se de 'fornecimento de tecnologia industrial' o contrato tem por finalidade específica a aquisição de conhecimentos e de técnicas não amparadas por direitos de propriedade industrial depositados ou concedidos no país, a serem aplicados na produção de bens de consumo ou de insumos, em geral."

${ }^{458}$ AN 15/75 Item 5.1: "Considera-se 'de cooperação técnico-industrial' o contrato que tem por finalidade específica a aquisição de conhecimentos, de técnicas e de serviços requeridos para a fabricação de unidades e sub-unidades industriais, de máquinas, equipamentos, respectivos componentes e outros bens de capital, sob encomenda."

${ }^{459}$ AN 15/75 Item 6.1: "Considera-se de 'serviços técnicos' o contrato que tenha por finalidade específica o planejamento, a programação, e a elaboração de estudos e projetos, bem como a execução ou a prestação de serviços, de caráter especializado, de que necessita o sistema produtivo do país."
} 
4.5.2 O contrato não poderá:

[...] b) estabelecer a obrigatoriedade de o adquirente ceder, a título gratuito, as inovações, melhoramentos ou aperfeiçoamentos por ele introduzidos ou obtidos no país com relação à tecnologia transferida, os quais poderão ser transmitidos ao fornecedor, nas mesmas condições da tecnologia transferida;

c) prever a realização de qualquer outro serviço, ajuste ou negociações entre as partes, que não tenha relação com o objeto do contrato;

d) conter, implícita ou explicitamente, cláusulas restritivas e/ou impeditivas ao fornecimento da tecnologia, bem como para as atividades do adquirente, as quais se referem, direta ou indiretamente, à Lei 5772/71 (Código da Propriedade Industrial) e a Lei 4137/62 (Regula a repressão ao abuso do Poder Econômico), principalmente a que:

(i) regule, determine, altere ou limite a produção, venda, preço, publicidade ou difusão, distribuição, comercialização ou exportação, bem como a contratação de pessoal e a reserva ou a distribuição de mercados a exclusão de algum deles, excetuado, neste último caso, quando admitida pela legislação de propriedade industrial, quando exigida comprovadamente por Legislação específica do país do fornecedor ou, ainda, quando decorrente de Ato ou Acordo Internacional de que o Brasil participe;

(ii) obrigue ou condicione a compra de insumos ou componentes necessários à fabricação do produto ou utilização do processo, ou de máquinas e equipamentos, do fornecedor da tecnologia, e/ou de outras fontes por ele determinadas, inclusive de procedência interna;

(iii) imponha o uso de marca ou propaganda estrangeira para o fornecimento da tecnologia;

(iv) contenha disposições passíveis de limitar, regular, alterar, interromper ou impedir a política e as atividades de pesquisa e desenvolvimento tecnológico do adquirente da tecnologia; ${ }^{460}$

(v) vise a impedir o adquirente de contestar, administrativamente ou mediante procedimento judicial, os direitos de propriedade industrial pretendidos ou obtidos no país pelo fornecedor da tecnologia;

(vi) impeça a livre utilização da tecnologia, após decorrido período julgado razoável a partir de cada uma das últimas informações transmitidas;

(vii) exima o fornecedor de responsabilidade frente a eventuais ações de terceiros, originadas de vícios, defeitos ou por infringência de direitos de propriedade industrial inerentes ao conteúdo tecnológico do contrato.

Há, portanto, menção específica no AN 15/75 à Lei 4.137/62, bem como orientações e diretrizes sobre o conteúdo de cláusulas contratuais ou de práticas contratuais restritivas. Além das disposições acima transcritas, o AN 15/75 também regulava expressamente prazos contratuais (Itens 4.4, 5.4, 6.4); formas e condições de cobrança dos pagamentos contratuais (Itens $4.2,4.3,5.2,5.3,6.2$ ); e fornecimento de informações [Itens 4.5.1 a) e c); 5.5.1 a) e c), 6.5.1 a) e c)]; cláusulas que, indiretamente, têm relação com o direito concorrencial.

Os Atos Normativos posteriores deixaram de mencionar especificamente a legislação de repressão ao abuso de poder econômico, ligando-a a práticas contratuais. Alguns

\footnotetext{
${ }^{460}$ Os Itens 5.5.2 e 6.5.2 do AN 15/75, referentes, respectivamente, às categorias cooperação técnico industrial e serviços técnicos especializados, contem disposições idênticas, alteradas mutatis-mutandis para a natureza específica de serviços.
} 
continuaram a mencionar somente cláusulas específicas que seriam proibidas. Outros mencionaram a legislação como genericamente aplicável.

Exemplificativamente, a Resolução 22/91 permite a estipulação de cláusulas de sigilo e indisponibilidade da tecnologia transferida, mas prevê a necessidade do fornecimento de informações necessárias à aplicação e atualização do objeto (art. $7^{\circ}, \S$ único, e $\operatorname{art.~} 9^{\circ}$ ); prevê a faculdade da autarquia de "suspender ou anular a averbação, por motivo de transgressão à lei vigente, fazendo cessar seus efeitos e oficiando imediatamente aos órgão competentes para as providências cabíveis" (art. 16) e estipula que as "exigências para averbação serão formuladas com base na legislação”. A Instrução Normativa 1/91 prevê, ainda, que aperfeiçoamento e melhoramentos introduzidos nos produtos ou processo objeto dos contratos pelo cessionário a ele pertencerão, sendo que as informações poderão ser transmitidas ao cedente (Item 1.1. c) . O Item 1.6 do instrumento previa, ainda, considerações acerca da remuneração contratual. ${ }^{461}$

Barbosa explicita que o cerne de atuação do INPI se manteve sob os citados normativos, mesmo após a revogação do AN 15/75. Não obstante referidos normativos tenham redação muito mais simplificada que seu antecessor Ato Normativo 15/75, a legislação de base para a transferência de tecnologia não havia sofrido qualquer alteração. ${ }^{462}$

O Ato Normativo 120/93, que revogou os instrumentos supra, inovou. Prevê expressamente em seu art. $4, \S \S 1^{\circ}$ e $2^{\circ}$ que:

[...] $\S 1^{\circ}$ Não serão objeto de análise ou de exigência por parte do INPI os dispositivos contidos nos atos ou contratos de que trata este Ato Normativo não especificamente relacionados aos aspectos elencados no 'caput' deste artigo, inclusive aqueles a que se refiram preço, condições de pagamento, tipo e condições de transferência de tecnologia, prazos contratuais, limitações de uso, acumulação de objetos contratuais, legislação aplicável, jurisdição competente e demais cláusulas. $\S 2^{\circ}$ Não poderá, destarte, o INPI recusar averbação com base em alegada violação de legislação repressora de concorrência desleal, legislação 'anti-trust' ou relativa a abuso de poder econômico, de proteção ao consumidor e outras, facultada ao INPI a opção de alertar as partes quanto aos aspectos legais pertinentes.

Barbosa entende que, independentemente do teor do Ato Normativo 120/93:

[...] persistem as competências do INPI no tocante à análise de legalidade intrínseca e o dever de suscitar a necessidade de pronunciamento do órgão de tutela da

\footnotetext{
${ }^{461}$ Vale salientar que entre 1990 e 1992, época da edição da Resolução 22/91 do Presidente do INPI e da Instrução Normativa 1/91 do Presidente do INPI, a autarquia encontrava-se subordinada ao Ministério da Justiça e não ao Ministério do Desenvolvimento, Indústria e Comércio Exterior.

${ }^{462}$ BARBOSA, D. B. Uma Introdução à Propriedade Intelectual, p. 981.
} 
concorrência em casos em que o contrato, na forma apresentada ao INPI, seria suscetível de violação das normas concorrenciais em vigor.

Isso porque, novamente, a legislação federal aplicável à matéria e que fundamenta as atividades do INPI não havia sido alterada. ${ }^{463}$

Independente da regulação administrativa da matéria pelo INPI, a doutrina da área concorrencial alega incompetência para o INPI aplicar a legislação de repressão ao abuso de poder econômico pelo INPI, ao menos a partir da promulgação da Lei 4.137/62, que criou o Conselho Administrativo de Defesa Econômica (CADE) e incumbiu-o "da apuração e da repressão dos abusos de poder econômico" (art. $\left.8^{\circ}\right) .{ }^{464}$ Barbosa discorda e entende que:

\begin{abstract}
A averbação no INPI cria pelo menos a presunção de validade, pela obrigação legal do órgão de zelar pela sanidade dos contratos objeto da averbação. Presumptio juris tantum, porém removível por prova contrária. O INPI não faz coisa julgada, a não ser nos limites precários da coisa julgada administrativa. [...] No nosso entendimento a averbação do ato ou contrato no INPI torna-se necessária para as seguintes finalidades: [...] reconhecer que, a juízo do INPI, a execução do negócio jurídico, tal como estipulado, tem condições de atender à legislação de repressão ao abuso de poder econômico. ${ }^{465}$
\end{abstract}

O Ato Normativo 135/97 (que substituiu o Ato Normativo 120/93), ainda em vigor, não faz menção específica a cláusulas e práticas restritivas da concorrência, limitandose a exigir que os contratos indiquem claramente seu objeto, remuneração, prazos de vigência e demais cláusulas e condições da contratação. O preâmbulo do Ato Normativo indica que a finalidade principal da autarquia é "executar as normas que regulam a Propriedade Industrial, tendo em vista sua função econômica, social, jurídica e técnica”. Em seu item 1, o Preâmbulo indica expressamente que a finalidade do Ato Normativo é "normalizar os procedimentos de averbação ou registro de contratos de transferência de tecnologia" "na forma da LPI e de legislação complementar", enumerando a seguir a legislação aplicável, incluindo no rol de diplomas a Lei 8.884/94 (lei de prevenção e repressão às infrações à ordem econômica) Decreto Legislativo 30/94 e Decreto Presidencial 1.355/94 (recepcionaram o TRIPS no ordenamento jurídico brasileiro).

\footnotetext{
${ }^{463}$ BARBOSA, D. B. Uma Introdução à Propriedade Intelectual, p. 983 . O autor suscita inclusive a ilegalidade do Ato Normativo 120/93, por ter sido editado sem amparo da legislação federal.

${ }^{464}$ Neste sentido: FRANCESCHINI, J. I. G. Os Contratos de Tecnologia como Forma de Abuso do Poder Econômico, p. 619; CARVALHO, N. T. P. Abusos de Direitos de Patente: Um Estudo do Direito dos Estados Unidos com Referências Comparativas ao Direito Brasileiro, p. 21 (já sobre a então em vigor Lei 8.158/91).

${ }^{465}$ BARBOSA, D. B. Uma Introdução à Propriedade Intelectual, p. 992 e 993.
} 
A Lei 9.279/96 silencia a respeito de cláusulas específicas em contratos de transferência de tecnologia e, ao contrário da lei anterior de propriedade industrial (5.772/71) também silencia sobre cláusulas proibidas em contratos de licença de marcas e patentes.

Ocorre que a legislação que regula as atividades do INPI foi alterada com esta lei. Conforme analisamos no Capítulo II, Item 2.5, com o advento da Lei 9.279/96 retira-se expressamente do rol de competências do INPI o conteúdo referente à aceleração e regulação da transferência de tecnologia das atribuições do INPI. ${ }^{466}$ Ainda, na mesma Lei 9.279/96 o artigo que dispõe sobre a necessidade do registro do contrato, art. 211, menciona somente a finalidade de produção de efeitos perante terceiros, não se referindo a medidas capazes de acelerar e regular a transferência de tecnologia ${ }^{467}$. Nota-se, claramente, uma flexibilização na normatização dos contratos de transferência de tecnologia. A moldura de atuação do INPI torna-se menos definida. Exige maior atenção quanto aos indicadores de cunho viés interpretativo a ser adotado pelo INPI na regulação.

Conforme o princípio da especialidade, operacionaliza-se a descentralização da administração pública. Di Pietro expõe:

Quando o Estado cria pessoas jurídicas públicas administrativas - as autarquias como forma de descentralizar a prestação de serviços públicos, com vistas à especialização de função, a lei que cria entidade estabelece com precisão as finalidades que lhe incumbe atender, de tal modo que não cabe aos seus administradores afastar-se dos objetivos definidos na lei; isto precisamente pelo fato de não terem a livre disponibilidade dos interesses públicos. ${ }^{468}$

Porém, entender que havia uma competência do INPI para a análise de aspectos concorrenciais em contratos de transferência de tecnologia ${ }^{469}$ anteriormente a 1996, cuja competência restou prejudicada pela retirada de suas funções relativas à instituição de "medidas capazes de acelerar e regular a transferência de tecnologia" não nos parece ser a interpretação correta. O INPI continua, com o advento da Lei 9.279/96, com a atribuição legal

\footnotetext{
${ }^{466}$ Lei 9.279/96, art. 240:

$\mathrm{O}$ art. $2^{\circ}$ da Lei 5.648. de 11 de dezembro de 1970, passa a ter a seguinte redação:

'Art. $2^{\circ} \mathrm{O}$ INPI tem por finalidade principal executar, no âmbito nacional, as normas que regulam a propriedade industrial, tendo em vista a sua função social, econômica, jurídica e técnica, bem como pronunciar-se quanto à conveniência de assinatura, ratificação e denúncia de convenções, tratados, convênios e acordos sobre propriedade industrial.'

${ }^{467}$ Lei 9.279/96, art. 211: “O INPI fará o registro dos contratos que impliquem transferência de tecnologia, contratos de franquia e similares para produzirem efeitos em relação a terceiros”.

${ }^{468}$ A autora acrescenta, ainda, ser um princípio normalmente referido às autarquias (DI PIETRO, M. S. Z. Direito Administrativo, p. 65).

${ }^{469}$ Não estamos nos referindo a contratos de licença de marcas e patentes, para os quais a Lei 5.772/71 dispunha especificamente.
} 
de executar as normas que regulam a propriedade industrial, tendo em vista sua função econômica, social, jurídica e técnica. Uma interpretação ampla da função social, econômica e jurídica da propriedade industrial permite-nos inferir que inclui também aspectos concorrenciais gerados por esses direitos. Mesmo a doutrina que alega a não existência de competência do INPI para verificar aspectos concorrenciais de transferência de tecnologia após o advento das Leis 4.137/62 e 8.158/91, citada supra, ${ }^{470}$ não se manifesta sobre o fato de que (i) a legislação que embasa a competência do INPI não ter sido alterada com o advento destas leis ${ }^{471}$ e (ii) a especialidade conferida por lei ao INPI para questões de transferência de tecnologia.

Um posicionamento coerente por parte da doutrina deveria entender que (i) nunca houve competência por parte do INPI para aplicar questões da legislação de concorrência a contratos envolvendo propriedade intelectual, ou que (ii) esta competência sempre existiu, sendo calibrada pelo Poder Executivo conforme a edição dos atos normativos específicos orientando a análise dos contratos pelo INPI. Partilhamos desta segunda posição.

Como autarquia vinculada ao Ministério do Desenvolvimento, da Indústria e do Comércio Exterior, a atuação do Instituto deve harmonizar-se, em primeiro lugar, com o escopo de funções designadas a esse Ministério pela Presidência da República e, em segundo lugar, com as funções que o próprio Ministério lhe incumbir. Ao Ministério do Desenvolvimento, da Indústria e do Comércio Exterior - e não ao Ministério da Justiça, ao qual o CADE está vinculado, cabe regular propriedade intelectual e transferência de tecnologia. $^{472}$

Em 2004, novo decreto (Decreto 5.147/04) ${ }^{473}$, promoveu a reestruturação do INPI com base nas linhas gerais da nova política industrial do Governo Federal ${ }^{474}$ e insere

\footnotetext{
${ }^{470}$ FRANCESCHINI, J. I. G. Os Contratos de Tecnologia como Forma de Abuso do Poder Econômico, p. 619; CARVAlHo, N. T. P. Abusos de Direitos de Patente: Um Estudo do Direito dos Estados Unidos com Referências Comparativas ao Direito Brasileiro, p. 21.

${ }^{471}$ Aliás, a Lei 5.772/71, que especificava a proibição de cláusulas restritivas da concorrência em contratos de licença de marcas e patentes, é posterior à Lei 4.137/62.; a Lei 9.279/96 é posterior à Lei 8.884/94.

${ }^{472}$ A lei de organização da Presidência de República e dos Ministérios dispõe expressamente que (i) a política de desenvolvimento da indústria, do comércio e dos serviços e (ii) a propriedade intelectual e transferência de tecnologia são assuntos da área de competência do Ministério do Desenvolvimento, da Indústria e do Comércio Exterior - Lei 10.683/03 e alterações posteriores, art. 27 inc. IX alíneas a) e b), respectivamente.

473 "Aprova a Estrutura Regimental e o Quadro Demonstrativo dos Cargos em Comissão e das Funções Gratificadas do Instituto Nacional da Propriedade Industrial - INPI, e dá outras providências - , Anexo I Estrutura Regimental do Instituto Nacional da Propriedade Industrial Capítulo I - Da Natureza e Finalidade Art. $1^{\circ}$ O Instituto Nacional da Propriedade Industrial - INPI, autarquia federal criada pela Lei 5.648, de 11 de dezembro de 1970 e vinculada ao Ministério do Desenvolvimento, Indústria e Comércio Exterior, com sede e
} 
novamente em diploma legal as atribuições do INPI especificamente em relação à transferência de tecnologia, desta vez vinculando a análise e decisão quanto à averbação de contratos de modo alinhado às diretrizes de política industrial e tecnológica aprovadas pelo Governo Federal.

Em se tratando da aplicação de questões concorrenciais a contratos de transferência de tecnologia utilizando-se dispositivos do TRIPS, os quais, conforme analisamos no Item imediatamente anterior, têm precedência sobre as regras gerais de concorrência brasileiras, ${ }^{475}$ pode-se argumentar com maior propriedade da especialidade do INPI em termos de questões de propriedade intelectual e de transferência de tecnologia frente ao Sistema Brasileiro de Defesa da Concorrência. ${ }^{476}$

A intersecção entre propriedade intelectual e direito da concorrência é complexa, conforme analisamos no primeiro item deste Capítulo, e não conseguirá ser solucionada sem um esforço conjunto de ambos os entes, INPI e CADE (ou SBDC) cada qual com sua especialidade e pontos fortes.

Em 1996, foi firmado um Convênio de Cooperação Técnica entre o INPI e o CADE visando a "troca de informações, prestação de consultoria, a realização de seminários e elaboração de estudos atinentes aos diversos setores da economia relacionados com a temática da defesa da ordem econômica." 477 Iniciativa louvável, dada a necessidade de cooperação

foro no Distrito Federal, tem por finalidade principal executar, no âmbito nacional, as normas que regulam a propriedade industrial, tendo em vista a sua função social, econômica, jurídica e técnica, bem como pronunciarse quanto à conveniência de assinatura, ratificação e denúncia de convenções, tratados, convênios e acordos sobre propriedade industrial, conforme o art. 240 da Lei 9.279, de 14 de maio de 1996. [...]

Art. 13. À Diretoria de Contratos de Tecnologia e Outros Registros compete:

I - analisar e decidir quanto à averbação de contratos para exploração de patentes, uso de marcas e ao que implique transferência de tecnologia e franquia, na forma da Lei 9.279, de 1996, de modo alinhado às diretrizes de política industrial e tecnológica aprovadas pelo Governo Federal; [...]" (grifos nossos).

${ }^{474}$ EM Interministerial 00178/MP/MDIC de 07/07/2004.

475 Estando internalizadas no ordenamento e sendo específicas. Vide: NGUYEN, T. T. The CFI's Ruling in Microsoft v. Commission, p. 564. Conforme Forgioni: "Por isso, quando dizemos que a Lei Antitruste é uma 'lei geral', no sentido atribuído pela teoria do direito, indicamos que, em princípio, a 'Lei Antitruste regula a concorrência de forma geral entre agentes econômicos'. Ela será 'geral' quando comparada a diplomas que lhe fazem escapar determinados setores ou práticas do regramento antitruste, submetendo-os a lógica diversa da concorrência plena ('leis específicas')" (FORGIONI, P. A interpretação dos negócios empresariais no novo código civil brasileiro, p. 226).

${ }^{476}$ Não existe na lei brasileira previsão expressa sobre um sistema brasileiro de defesa da concorrência formalmente constituído. Na prática, tal denominação foi consagrada para se fazer alusão aos três órgãos envolvidos na tutela da concorrência, quando considerados em conjunto.

Vale ressaltar que também é atribuição do INPI "[...] pronunciar-se quanto à conveniência de assinatura, ratificação e denúncia de convenções, tratados, convênios e acordos sobre propriedade industrial”. Lei 5.648/70, art. $2^{\circ}$.

${ }^{477}$ Disponibilizado à autora por fax pelo CADE no dia 19/08/1997. 
entre os órgãos para que a defesa da concorrência efetivamente se realize nesta área, conforme frisado exaustivamente pela doutrina internacional. ${ }^{478}$ Entretanto, não há informações sobre feitos realizados sob esse Convênio ou mesmo de reuniões entre os órgãos realizadas a partir de sua assinatura. Sua redação é genérica e não impõe obrigações aos órgãos no sentido de efetivamente cooperarem e se reunirem, possivelmente este tenha sido o maior defeito do Convênio. ${ }^{479}$

Após 1996 e sob a égide do Ato Normativo 135/97, o INPI continuou a fazer considerações de cunho concorrencial quanto a algumas cláusulas do contrato de transferência de tecnologia fornecido para registro. Na realidade, a mudança que se observa é que ao invés de condicionar o registro do contrato à exclusão da respectiva cláusula, a autarquia passou a emitir o Certificado de Averbação acompanhado de carta, parte integrante do Certificado, no qual alertava para os efeitos negativos para a parte receptora e efeitos adversos para a concorrência das cláusulas específicas.

Vale ressaltar, porém, que algumas cláusulas continuavam e continuam sendo vedadas pelo INPI. Exemplificativamente, prazos de duração e de confidencialidade eram (e ainda o são) unilateralmente reduzidos pelo Instituto (quando considerados excessivamente extensos), insumos e componentes eram (e ainda são) excluídos da base de cálculo dos pagamentos $^{480}$, formas específicas de pagamento são impostas a categorias de contratos. ${ }^{481}$ É preciso avaliar sob qual argumentação o INPI veda essas cláusulas nos contratos de transferência de tecnologia. A justificativa para a negativa de inclusão de práticas restritivas contratuais assume diferentes vertentes, hora pretendendo fortalecer a posição da parte receptora e o incremento do parque tecnológico nacional (para a interpretação da transferência definitiva da tecnologia e não de sua licença), hora como interpretação da legislação tributária (para a limitação do prazo contratual). Do ponto de vista da legislação concorrencial, pode-se afirmar que desde o Ato Normativo 120/93 $3^{482}$ o INPI limita-se a inquirir sobre os motivos de

\footnotetext{
${ }^{478}$ Vide ICTSD - International Centre for Trade and Sustainable Development. Intellectual Property and Competition Law - Exploring Some Issues of Relevance to Developing Countries, p. xi e 2, e NGUYEN, T. T. The CFI's Ruling in Microsoft v. Commission, p. 579 e ss.

${ }^{479}$ Conforme a Lei que regula o processo administrativo no âmbito da Administração Pública Federal, Lei 9.784/99, art. 35: "Quando necessária à instrução do processo, a audiência de outros órgãos ou entidades administrativas poderá ser realizada em reunião conjunta, com a participação de titulares ou representantes dos órgãos competentes, lavrando-se a respectiva ata, a ser juntada aos autos."

${ }^{480}$ Vide Capítulo II Item 3.2.1.

${ }^{481}$ Negativa de pagamentos fixos para fornecimentos de tecnologia, necessidade de cobrança homem-hora para serviços, entre outros.

${ }^{482}$ Inspirado no seu art. $4^{\circ} \S 2^{\text {o }}$ : "Não poderá, destarte, o INPI recusar averbação com base em alegada violação de legislação repressora de concorrência desleal, legislação 'anti-trust' ou relativa a abuso de poder econômico,
} 
inclusão da cláusula e, em não sendo retirada, atenta para potenciais efeitos nocivos à concorrência que ela pode gerar, na carta que acompanha o Certificado de Averbação. O conteúdo da carta que acompanha o Certificado de Averbação tem o condão de informar. A natureza jurídica da carta, em relação a esse item específico, é exatamente este informacional.

Em sendo o direito da concorrência brasileiro um direito instrumental e que não protege a concorrência em si mesma, a sua adaptação sob esses vértices para a análise dos contratos de transferência de tecnologia é perfeitamente possível; entenda-se por transferência de tecnologia aqueles contratos sujeitos ao registro do INPI, já que cabe a esta autarquia, conforme a delegação que recebeu do Ministério da Indústria, do Desenvolvimento e do Comércio Exterior, a regulação da propriedade intelectual e da transferência de tecnologia no país. $^{483}$

Conforme posição expressada pela Diretoria de Contratos e Outros Registros do INPI, a autarquia é responsável pela repressão ao abuso de poder econômico quando da revisão dos contratos. ${ }^{484} \mathrm{Se}$ a aplicação da Lei $8.884 / 94$ pelo INPI continuar a ocorrer nos moldes imediatamente acima descritos, não vemos qualquer conflito de competências. ${ }^{485}$

Porém, a situação que existe hoje quanto à análise concorrencial das cláusulas restritivas em contratos envolvendo direitos de propriedade industrial é insatisfatória para o país. A atuação do INPI acima descrita, informando, não traz efeitos práticos. Por outro lado, o SBDC não revê de forma sistemática práticas negociais restritivas em contratos envolvendo

de proteção ao consumidor e outras, facultada ao INPI a opção de alertar as partes quanto aos aspectos legais pertinentes" (grifamos).

${ }^{483}$ Vide Capítulo 2, Item 2.5.

${ }^{484}$ Conforme apresentação da Diretoria de Contratos e Outros Registros do INPI - DIRTEC no painel setorial da Inmetro em 2007, são atribuições da autarquia ao rever os contratos de transferência de tecnologia: (i) A Regulação dos Fluxos de Tecnologia e, (ii) no Campo Legislativo, rever os seguintes assuntos: 1 - Popriedade Intelectual, sobretudo a Propriedade Industrial. 2 - Comércio Exterior, principalmente a relacionada ao capital estrangeiro. 3 - Fiscal e tributário. 4 - Abuso de poder econômico. Disponível em: <http://www. inmetro.gov.br/painelsetorial/palestras/INPI.pdf>. Acesso em 16/02/2010).

${ }^{485}$ Vaz e Dias entende que até mesmo o pronunciamento sobre cláusulas potencialmente anti-competitivas em contratos de transferência de tecnologia é de legalidade questionável, em vista do princípio da especialidade que norteia a administração pública. Acrescenta: "Na verdade, esses pronunciamentos produzem apreensão e insegurança aos agentes econômicos em virtude do impacto econômico e político das decisões do INPI" (VAZ e DIAS, J. C. Os Princípios da Legalidade e da Competência e os Limites de Atuação do INPI no Direito da Concorrência, p. 21). O autor não atribui a referidos pronunciamentos quaisquer efeitos jurídicos, conseqüentemente, não conseguimos vislumbrar qualquer ilegalidade. Ademais, entendemos que o princípio da especialidade pode ser utilizado justamente para argumentar a competência do INPI para esta revisão, conforme exposto supra. Referimo-nos, ademais, às nossa considerações sobre o princípio da legalidade e as competências do INPI analisadas no Capítulo II Item 2.5. 
direitos de propriedade intelectual. A legislação concorrencial e, especialmente, a limitação de práticas restritivas em contratos, exceção arduamente negociada no âmbito do TRIPS, permanece inócua, sem aplicação em território nacional. ${ }^{486}$ Não foi editada qualquer regulação ou diretriz a esse respeito e o TRIPS foi incorporado ao ordenamento jurídico pátrio em 1994, há mais de quinze anos.

Nosso posicionamento é pela necessidade de cooperação entre o INPI e o SBDC a fim de atingir-se uma regulação do assunto que seja satisfatória para atender aos interesses nacionais. A revisão pelo INPI de práticas restritivas de negócios em contratos de transferência de tecnologia ocorre antes do contrato produzir efeitos em relação a terceiros. ${ }^{487}$ A aprovação do contrato pela autoridade concorrencial não é, em princípio, condição para sua eficácia, o que ocorre no registro do contrato pelo INPI.

Logo, entendemos perfeitamente possível a coordenação das atividades de ambos os órgãos administrativos. O INPI teria a competência de uma verificação da presença de condutas nos contratos, dada a competência do órgão de registrar esses contratos para que produzam efeitos em relação a terceiros e "executar as normas que regulam a Propriedade Industrial, tendo em vista sua função econômica, social, jurídica e técnica." ${ }^{488}$ As diretrizes para esta verificação podem e devem ser elaboradas em conjunto com o SBDC. ${ }^{489}$ Já ao SBDC, caberia a liberação pela regra da razão destas cláusulas. Não estamos aqui sugerindo a

${ }^{486}$ Conforme Coelho, "nosso Direito, diferentemente, não possui esta extensão. Afinal, o CADE (Conselho Administrativo de Defesa Econômica) deve analisar as fusões, incorporações e os atos que possam limitar a concorrência. Por exemplo, contratos de prestação de serviços, contratos de financiamento, uma sériede operações, na Alemanha devem estar submetidos ao controle do órgão de defesa da concorrência, uma vez que eles já trabalham com um conceito de controle muito mais amplo; conceito não fundado exclusivamente na titularidade de ações, e que atende aos objetivos do Direito da Concorrência. [...] Um segundo mecanismo de controle não fundado na titularidade de ações é aquele baseado em contratos de prestação de serviços que levam o prestador a controlar o contratante dos serviços; ainda mais numa área de tecnologia avançada, como na de telecomunicações, o detentor de uma tecnologia nova deve defender esta tecnologia. Os mecanismos de propriedade intelectual nem sempre são eficazes. Muitas vezes é necessário garantir o segredo de indústria, ao invés de obter a patente, que pressupõe a necessária divulgação do objeto. Assim, o titular de uma tecnologia altamente avançada mantida em segredo apenas presta um serviço na empresa alheia se o contrato garantir condições de preservação de segredo. Isto envolve ingerência na administração da empresa que esta contratando o serviço. Os instrumentos de controle são encontrados nos próprios contratos de prestação de serviços" (COELHO, F. U. Reforma do Estado e Direito Concorrencial, p. 198 e 199).

${ }^{487}$ Exceção ocorreu à época em que a Resolução 22/91 estava em vigor, quando o INPI poderia, conforme o art. 16, propor a suspensão ou anulação do registro do contrato com base em transgressão da legislação vigente. Este dispositivo não foi reproduzido nos normativos seguintes e não temos conhecimento de sua aplicação na prática pelo INPI.

${ }^{488}$ Lei 5.648/70, art. $2^{\circ}$.

${ }^{489}$ Conforme NGYUEN, T. T. The CFI's Ruling in Microsoft v. Commission. IIC, vol. 39 5/1002, p. 579 e ss., um dos principais obstáculos à regulação da transferência de tecnologia nos países em desenvolvimento é a falta de cooperação e de comunicação entre os órgão de defesa da propriedade intelectual e da concorrência. Neste sentido também: ICTSD - International Centre for Trade and Sustainable Development. Intellectual Property and Competition Law - Exploring Some Issues of Relevance to Developing Countries, p. xi e 2. 
introdução de regras de ilícitos concorrenciais per se. Trata-se de propor alternativa que torne a revisão concorrencial sistemática dos contratos de transferência de tecnologia viável, a fim de fazer jus à restrição arduamente negociada no âmbito do TRIPS. Proporemos um modelo de regulação no Item 4.3.2, infra. ${ }^{490}$

\title{
4.2. A Aplicação da Lei 8.884/94 ao Contrato de Transferência de Tecnologia
}

Conforme o art. $1^{\circ}$ da Lei sobre a Prevenção e a Repressão às Infrações contra a Ordem Econômica, Lei 8.884/94:

\begin{abstract}
Esta lei dispõe sobre a prevenção e repressão às infrações contra a ordem econômica, orientada pelos ditames constitucionais da liberdade de iniciativa, livre concorrência, função social da propriedade, defesa dos consumidores e repressão ao abuso de poder econômico.

Parágrafo Único. A coletividade é a titular dos bens jurídicos protegidos por esta lei.
\end{abstract}

Grau expressa que as referências aos princípios constitucionais contidas no art. $1^{\mathrm{o}}$ definem a amplitude do conteúdo da lei, não se trata meramente de uma lei antitruste, mas de uma lei "voltada à preservação do modo de produção capitalista", "ainda que seja, também, instrumento de política pública”. O princípio da livre concorrência no quadro da Constituição Federal "assume um sentido conformado pelo conjunto dos demais princípios por ela contemplados, seu conteúdo é determinado pela sua inserção em um contexto de princípios, no qual e com os quais subsiste em harmonia." ${ }^{491}$ Claramente, então, adota o Brasil o sistema da concorrência-meio. ${ }^{492}$

\footnotetext{
${ }^{490} \mathrm{O}$ controle preventivo dos atos contrários à livre concorrência na Lei 8.884/94, de forma similar ao art. 81 Inciso 3 do Tratado de Roma, traz a questão dos efeitos benéficos à economia e à sociedade, exatamente a hipótese à qual se aplicam os Regulamentos por isenção de categoria, conforme analisamos no Item 3 supra. Propomos justamente uma forma de Regulamento de isenção por categoria aos contratos de transferência de tecnologia no Brasil, com dupla finalidade: declarar a. (Vide Item 4.3.2 infra). Não entendemos ter de lidar aqui com a problemática da arbitrariedade da isenção, pois estaríamos diante de uma moldura ainda mais restritiva do que aquela fornecida pelo direito da concorrência. A moldura da absorção e difusão do conhecimento tecnológico, à qual a concorrência é instrumentalizada, dado o interesse coletivo. (Vide Item 1.4 supra). Conforme Forgioni: "[...] a concessão de autorização pode ser (e geralmente o é) diretamente derivada da política econômica atuada pelo órgão, em um determinado momento" (FORGIONI, P. A interpretação dos negócios empresariais no novo código civil brasileiro, p. p. 230). Sobre a questão da arbitrariedade na interpretação das isenções vide p. 224 da obra da autora.

${ }^{491}$ GRAU, E. Equidade, Razoabilidade e Proporcionalidade, p. 211 e 212.

${ }^{492}$ Conforme PROENÇA, J. M. M. Concentração Empresarial e o Direito da Concorrência, p. 39 e 40: “Assim, pode-se verificar que, dependendo do bem jurídico a ser tutelado pela lei de defesa da concorrência, temos diversas respostas jurídicas ao ato praticado pelo agente econômico, surgindo os dois grandes sistemas de defesa da concorrência: sistema da concorrência-fim, também chamado de concorrência-condição, na qual a
} 
Como atividade econômica, a transferência de tecnologia certamente poderá produzir efeitos anticoncorrenciais, que se não estiverem legitimados por alguma exceção prevista em lei serão coibidos. Conforme Kubrusly: “[...] mesmo na ausência de leis ou diretrizes específicas sobre interface entre propriedade intelectual e direito antitruste, no seu contorno atual, o exercício dos direitos oriundos da propriedade intelectual no Brasil não está imune ao direito da concorrência [...]."

O controle de condutas no direito brasileiro centra-se em dois dispositivos: os arts. 20 e 21 da Lei 8.884/94. Trata-se do sistema de cláusula geral e tipificação pormenorizada, mas exemplificativa. ${ }^{494}$ Ainda que seja difícil relacionar e classificar as condutas do artigo 21 nas hipóteses do art. 20, esta é a forma pela qual se concede sentido às condutas no âmbito da Lei 8.884/94, classificação de rigor conforme Salomão Filho. ${ }^{495}$

Assim, às práticas restritivas de negócios sob o contrato de transferência de tecnologia aplica-se, de maneira geral, o art. 20:

\footnotetext{
Art. 20. Constituem infração da ordem econômica, independentemente de culpa, os atos sob qualquer forma manifestados, que tenham por objeto ou possam produzir os seguintes efeitos, ainda que não sejam alcançados:

I - limitar, falsear ou de qualquer forma prejudicar a livre concorrência ou a livre iniciativa;

II - dominar mercado relevante de bens ou serviços;

III - aumentar arbitrariamente os lucros;

IV - exercer de forma abusiva posição dominante.

$\S 1^{\circ}$ A conquista de mercado resultante de processo natural fundado na maior eficiência de agente econômico em relação a seus competidores não caracteriza o ilícito previsto no inciso II.

$\S 2^{\circ}$ Ocorre posição dominante quando uma empresa ou grupo de empresas controla parcela substancial de mercado relevante, como fornecedor, intermediário, adquirente ou financiador de um produto, serviço ou tecnologia a ele relativa.

$\S 3^{\circ}$ A posição dominante a que se refere o parágrafo anterior é presumida quando a empresa ou grupo de empresas controla $20 \%$ (vinte por cento) de mercado relevante,
}

concorrência aparece como um objetivo, ou seja, a concorrência é um fim em si mesmo, trata-se do fim máximo a ser tutelado pela legislação; e o sistema da concorrência-meio, também chamado de concorrência instrumento, na qual a concorrência é vista como um instrumento utilizado para se chegar a um outro objetivo que é ainda maior, objetivo esse que, para ser definido, depende do país, do momento econômico, das políticas públicas, dos valores previstos na ordem econômica constitucional, etc."

${ }^{493}$ KUBRUSLY, C. T. Direito Antitruste e Propriedade Intelectual: Análise Concorrencial dos Acordos de Licença e da Recusa de Licenciar, p. 49.

494 “O primeiro dispositivo define, com fórmulas gerais, três tipos de ilícitos: a concorrência desleal (inciso I), os atos tendentes à dominação do mercado relevante de bens e serviços (inciso II) e o abuso de posição dominante (inciso III). Em seguida, o art. 21 enumera de forma exemplificativa as hipóteses em que os ilícitos do art. 20 podem se verificar" (SALOMÃO FILHO, C. Direito Concorrencial - As Condutas, p. 99 e ss.). Discordamos do autor ao interpretar o Inciso I como afeito à concorrência desleal, por estar esta fora do escopo publicístico da Lei 8.884/94 (vide Item 1.2 supra). Salomão Filho lembra que o aumento arbitrário dos lucros é modalidade de abuso de posição dominante e apresenta a discussão doutrinária em torno da permissibilidade de se aceitar a listagem do art. 21 como exemplificativa das condutas, posição que defende e com a qual concordamos.

${ }^{495}$ SALOMÃO FILHO, C. Direito Concorrencial - As Condutas, p. 103. 
podendo este percentual ser alterado pelo Cade para setores específicos da economia.

E, de forma exemplificativa as seguintes condutas do art. 21:

Art. 21. As seguintes condutas, além de outras, na medida em que configurem hipótese prevista no art. 20 e seus incisos, caracterizam infração à ordem econômica:

I - fixar ou praticar, em acordo com concorrente, sob qualquer forma, preços e condições de venda de bens ou de prestação de serviços;

II - obter ou influenciar a adoção de conduta comercial uniforme ou concertada entre concorrentes;

III - dividir os mercados de serviços ou produtos, acabados ou semi-acabados, ou as fontes de abastecimento de matérias-primas ou produtos intermediários;

IV - limitar ou impedir o acesso de novas empresas ao mercado;[...]

VI - impedir o acesso de concorrente às fontes de insumo, matérias-primas, equipamentos ou tecnologia, bem como aos canais de distribuição; [...]

$\mathrm{X}$ - regular mercados de bens ou serviços, estabelecendo acordos para limitar ou controlar a pesquisa e o desenvolvimento tecnológico, a produção de bens ou prestação de serviços, ou para dificultar investimentos destinados à produção de bens ou serviços ou à sua distribuição;

XI - impor, no comércio de bens ou serviços, a distribuidores, varejistas e representantes, preços de revenda, descontos, condições de pagamento, quantidades mínimas ou máximas, margem de lucro ou quaisquer outras condições de comercialização relativos a negócios destes com terceiros;

XII - discriminar adquirentes ou fornecedores de bens ou serviços por meio da fixação diferenciada de preços, ou de condições operacionais de venda ou prestação de serviços; [...]

XIV - dificultar ou romper a continuidade ou desenvolvimento de relações comerciais de prazo indeterminado em razão de recusa da outra parte em submeterse a cláusulas e condições comerciais injustificáveis ou anticoncorrenciais; [...]

XVI - açambarcar ou impedir a exploração de direitos de propriedade industrial ou intelectual ou de tecnologia; [...]

XXIII - subordinar a venda de um bem à aquisição de outro ou à utilização de um serviço, ou subordinar a prestação de um serviço à utilização de outro ou à aquisição de um bem;

XXIV - impor preços excessivos, ou aumentar sem justa causa o preço de bem ou serviço. [...]

Conforme analisamos no Item 1.4, cláusulas usuais em contratos de transferência de tecnologia e que estariam no escopo de atuação do exercício ${ }^{496}$ do direito ao segredo de negócio, que é objeto da tutela da concorrência, teríamos as seguintes cláusulas:

(i) limitação de escopo geográfico ou territorial de atuação no uso da tecnologia, [Lei 8.884/94; art. 21, incs. II; III; IV; X; XIV]

\footnotetext{
${ }^{496}$ Conforme analisamos no Item 1.4 supra, ao tratar de limites em relação a (i) exclusividade de uso e (ii) limitação de uso da tecnologia após prazo contratual; lidamos, no caso do segredo de negócio, com a confidencialidade da informação e seu controle, portanto, com os limites mesmo de proteção da propriedade intelectual e não com o seu exercício. Entendemos estas cláusulas como exteriores ao direito da concorrência e como integrantes dos limites da atuação do INPI e do Judiciário, mas não do SBDC. Vide Itens 1.2, 1.3 e 1.4 supra.
} 
(ii) limitação de área de aplicação da tecnologia conforme produtos/segmento; [Lei 8.884/94; art. 21, incs. II; III; IV; X; XIV]

(iii) necessidade de fornecimento de melhorias e aperfeiçoamentos feitos na tecnologia pela parte receptora à fornecedora; [Lei 8.884/94; art. 21, incs. X; XIV; XVI]

(iv) pagamento de níveis mínimos de remuneração, independente de performance [Lei 8.884/94; art. 21, incs. XII; XIV; XXIV];

(v) imposição da compra de insumos e componentes de terceiros determinados; [Lei 8.884/94; art. 21, incs. III; VI; X; XII; XIV; XXIII]

(vi) imposição de receber e pagar por um pacote total de tecnologia, relativo a vários produtos e serviços diferentes; [Lei 8.884/94; art. 21, incs. VI; X; XII; XIV; XIII]

(vii) proibição do questionamento judicial da tecnologia e seu status de segredo de negócio pela parte receptora; [Lei 8.884/94; art. 21, incs. XIV]

(viii) imposição do preço de revenda do produto ou do serviço oriundo da tecnologia. [Lei 8.884/94; art. 21, incs. I; XI; XII; XIV; XXIV]

Ao contrário do que ocorre na Comunidade Econômica Européia, na qual deve haver o potencial efetivo de afetação da concorrência entre os Estados-Membros, a fim de que se caracterize a infração, definido por meio de participações de mercado ${ }^{497}$ a análise brasileira independe de um critério específico de participação relevante no mercado ou de verificação de posição dominante. ${ }^{498}$ No entanto, conforme explicita Forgioni, embora baste para a lei brasileira que existam determinados objetivos ou a produção dos efeitos previstos no art. 20 da Lei 8.884/94, para que ocorra o ilícito deve restar caracterizada uma infração à ordem econômica. ${ }^{499}$ Esta infração inexistirá quando uma empresa com diminuto poder de mercado não for apta a praticar atos que levem ao prejuízo para a livre iniciativa ou livre

\footnotetext{
${ }^{497}$ Vide Item 3 supra, em especial a questão da "Bagatellbekantmachung".

${ }^{498} \mathrm{O}$ art. $20, \S 3^{\circ}$, estabelece uma presunção para a posição dominante: o controle de $20 \%$ do mercado relevante.

${ }^{499}$ Conforme Forgioni: "Já o sistema da lei brasileira, é um sistema híbrido, que aproveita o europeu no que tange à caracterização do ilícito pelo objeto ou efeito, mas supera tanto esta tradição quanto aquela norteamericana no que tange à tipificação dos atos. Tomando como ponto cardeal o objeto ou efeito da prática analisada, o art. 20 da Lei 8884, de 1994, refere-se aos 'atos, sob qualquer forma manifestados', englobando, a um só tempo, os acordos e as concentrações entre empresas, o domínio de mercado e o abuso de posição dominante" (FORGIONI, P. A interpretação dos negócios empresariais no novo código civil brasileiro, p. 147 e ss.).
} 
concorrência. $^{500}$ Salomão Filho entende que a classificação das condutas do art. 21 nas hipótese do art. 20 cumpriria esta função, com a ressalva de que o inciso I do art. 20 não pode ser utilizado como tipo residual. ${ }^{501}$

Ainda assim, entendemos que a possibilidade de práticas restritivas usuais em contratos de transferência de tecnologia se caracterizarem como conduta ilícita vis-à-vis o direito concorrencial brasileiro é muito elevada, conforme o enquadramento das práticas entre os incisos do art. 21 que, exemplificativamente, efetuamos supra. Isso porque, conforme analisamos ao longo deste Capítulo, o exercício do direito de propriedade intelectual, pela sua própria natureza, implicará uma restrição à livre concorrência.

O alívio vem do art. 54 da Lei 8.884/94, como sistema de autorização. O art. 54 traz a possibilidade da prova da licitude, que se faz vis-à-vis seus efeitos benéficos tendo em vista os outros bens e interesses tutelados pela lei. ${ }^{502}$ Estabelece: ${ }^{503}$

Do Controle de Atos e Contratos

Art. 54. Os atos, sob qualquer forma manifestados, que possam limitar ou de qualquer forma prejudicar a livre concorrência, ou resultar na dominação de mercados relevantes de bens ou serviços, deverão ser submetidos à apreciação do Cade.

$\S 1^{\circ} \mathrm{O}$ Cade poderá autorizar os atos a que se refere o caput, desde que atendam as

\footnotetext{
${ }^{500}$ Vide FORGIONI, P. A interpretação dos negócios empresariais no novo código civil brasileiro, p. 150 e ss.

501 "Assim, todo e qualquer acordo entre concorrentes (de preços, quantidade produzida, etc.) só chega a representar perigo para o sistema concorrencial se puder efetivamente levar à formação de uma posição de poder nos mercados. Só assim será possível atingir o objetivo final desse tipo de acordo.”

“[...] O que ocorre é que esse caráter residual inexiste. O inciso I do art. 20 é a explicação da hipótese do inciso II." Utilizando-se da teoria da incipiência, o autor defende que haverá dominação de mercado toda vez que existir risco de limitar a concorrência em seu sentido institucional, isto é, reduzir a escolha do consumidor. "Isto ocorrerá tanto quando houver risco de exclusão de concorrente ou de colusão entre concorrentes que possa ter impacto sobre o mercado, limitando a escolha do consumidor (SALOMÃO FILHO, C. Direito Concorrencial As Condutas, p. 104 e 121 e ss.).

${ }^{502}$ Conforme Shieber, a lei brasileira desconhece o ilícito per se e admite a aplicação da regra da razão a todos os casos de restrição de concorrência. Analisando os efeitos da análise caso-a-caso prevista na lei, Shieber, B. M. dispõe: "Assim, é possível que um acordo para fixação de preços seja lícito numa época, e o mesmo acordo entre as mesmas empresas seja ilícito noutra época. A mudança de situação econômica na indústria ou no país pode servir como base da diferença nos dois julgamentos" (SHIEBER, B. M. Abusos do Poder Econômico: Direito e Experiência Anti-truste no Brasil e nos E.U.A. São Paulo: Revista dos Tribunais, 1966, p. 138).

Forgioni conclui que é impossível a legitimação de prática que tenha por objeto ou efeito o aumento arbitrário de lucros ou abuso de posição dominante (FORGIONI, P. Os Fundamentos do Antitruste, p. 224. Realmente, interpretando o caput do art. 54 e relacionando-o com o art. 20, salta aos olhos o fato dos dois últimos incisos do art. 20 não estarem mencionados no art. 54.

${ }^{503}$ Forgioni esclarece que, "[...] no Brasil, a matriz legal para análise tanto das concentrações, quanto dos acordos entre os agentes econômicos é a mesma (art. 54 da Lei 8884, de 1994) [...]” (FORGIONI, P. Os Fundamentos do Antitruste, p. 225). Conforme Assafim, “o art. 54, embora seja tradicionalmente aplicado pela Administração de forma praticamente exclusiva no campo do controle 'a posteriori' de atos de concentração, os termos [de que] se utiliza [são] de suficientemente amplos e abertos para estender sua aplicação a outros setores, como acordos contidos em contratos de transferência de tecnologia". (Inclusões nossas entre colchetes para facilitar o entendimento do texto) (ASSAFIM, J. M. A Transferência de Tecnologia no Brasil Aspectos Contratuais e Concorrenciais da Propriedade Industrial, p. 276).
} 
seguintes condições:

I - tenham por objetivo, cumulada ou alternativamente:

a) aumentar a produtividade;

b) melhorar a qualidade de bens ou serviço; ou

c) propiciar a eficiência e o desenvolvimento tecnológico ou econômico;

II - os benefícios decorrentes sejam distribuídos equiitativamente entre os seus participantes, de um lado, e os consumidores ou usuários finais, de outro;

III - não impliquem eliminação da concorrência de parte substancial de mercado relevante de bens e serviços;

IV - sejam observados os limites estritamente necessários para atingir os objetivos visados. [...]

$\S 2^{\circ}$ Também poderão ser considerados legítimos os atos previstos neste artigo, desde que atendidas pelo menos três das condições previstas nos incisos do parágrafo anterior, quando necessários por motivo preponderantes da economia nacional e do bem comum, e desde que não impliquem prejuízo ao consumidor ou usuário final.

$[\ldots]$

A propriedade intelectual e seu exercício - incluindo o exercício da posição da fato conferida pelo segredo de negócio inserto em contrato de transferência de tecnologia tem usualmente por objetivo "aumentar a produtividade, melhorar a qualidade de bens ou serviço, bem como propiciar a eficiência e o desenvolvimento tecnológico ou econômico."504

Porém, é preciso atentar para o inciso II: “os benefícios decorrentes sejam distribuídos eqüitativamente entre os seus participantes, de um lado, e os consumidores ou usuários finais, de outro". Aplicando-se o interesse da coletividade de difusão e absorção da tecnologia em território brasileiro, encontramos na própria Lei 8.884/94 a instrumentalização da concorrência necessária para a regulação do contrato de transferência de tecnologia.

Entretanto, conforme os parágrafos seguintes do art. 54, a autorização da prática restritiva em um contrato de transferência de tecnologia está sujeita a um processo específico de aceitação:

[...] $\S 4^{\circ}$ Os atos de que trata o caput deverão ser apresentados para exame, previamente ou no prazo máximo de quinze dias úteis de sua realização, mediante encaminhamento da respectiva documentação em três vias à SDE, que imediatamente enviará uma via ao Cade e outra à Seae. (Redação dada pela Lei $\mathrm{n}^{\circ}$ 9.021, de 30.3.95)

$\S 5^{\circ} \mathrm{A}$ inobservância dos prazos de apresentação previstos no parágrafo anterior será punida com multa pecuniária, de valor não inferior a 60.000 (sessenta mil) Ufir nem superior a 6.000.000 (seis milhões) de Ufir a ser aplicada pelo Cade, sem prejuízo da abertura de processo administrativo, nos termos do art. 32 .

\footnotetext{
${ }^{504}$ Vale ressaltar que a melhoria tecnológica não é apta a justificar, por si só, a conduta. Os demais requisitos dos demais incisos do artigo devem estar presentes: os benefícios sejam distribuídos equitativamente aos participantes, consumidores e usuários finais; não impliquem a eliminação da concorrência de parte substancial do mercado relevante de bens e serviços e sejam observados os limites estritamente necessários para atingir os objetivos visados.
} 
$\S 6^{\circ}$ Após receber o parecer técnico da Seae, que será emitido em até trinta dias, a SDE manifestar-se-á em igual prazo, e em seguida encaminhará o processo devidamente instruído ao Plenário do Cade, que deliberará no prazo de sessenta dias.

$\S 7^{\circ}$ A eficácia dos atos de que trata este artigo condiciona-se à sua aprovação, caso em que retroagirá à data de sua realização; não tendo sido apreciados pelo Cade no prazo estabelecido no parágrafo anterior, serão automaticamente considerados aprovados.

$\S 8^{\circ}$ Os prazos estabelecidos nos $\S \S 6^{\circ}$ e $7^{\circ}$ ficarão suspensos enquanto não forem apresentados esclarecimentos e documentos imprescindíveis à análise do processo, solicitados pelo Cade, SDE ou SPE. [...]

Assim, o processo de autorização implicaria uma notificação anterior à execução do contrato, ou dentro de quinze dias de sua execução, à Secretaria de Direito Econômico (SDE), que remeterá copia da notificação ao CADE e à Secretaria de Acompanhamento Econômico (SEAE). SDE e SEAE emitirão pareceres, cada qual em trinta dias, e o plenário do CADE decidirá em até sessenta dias. Conforme salientado por Assafim, “o sistema de autorizações estabelecido pela LDC [Lei da Concorrência] no Brasil corresponde ao esquema de 'autorizações singulares', isto é, o CADE examina e avalia cada ato de conduta individualmente.,

Conforme o art. 28 da Lei 8.884/94, as infrações à ordem econômica prescreverão em cinco anos, a partir da data da prática do ilícito. No caso de infração permanente ou continuada (que se daria de fato com a execução do contrato) o prazo e conta do dia em que tiver cessado.

Um normativo regulando a isenção do procedimento de aprovação para determinadas práticas negociais restritivas em contratos de transferência de tecnologia é necessário e poderia ser inserido na moldura jurídica já existente. ${ }^{506}$

\footnotetext{
505 ASSAFIM, J. M. A Transferência de Tecnologia no Brasil Aspectos Contratuais e Concorrenciais da Propriedade Industrial, p. 278 (inclusões entre colchete nossas, para facilitar o entendimento).

${ }^{506}$ Conforme Forgioni: "Vê-se, portanto, que o sistema jurídico brasileiro admite a existência de isenções à Lei Antitruste. Como demonstrado, não é necessária disposição expressa nesse sentido; a legalidade e constitucionalidade das leis específicas autorizadoras de práticas anticompetitivas decorrem diretamente da Constituição Federal. Enfim, a 'viabilidade de uma isenção em bloco, no Brasil, brota da interpretação sistemática do nosso direito"” (FORGIONI, P. Os Fundamentos do Antitruste, p. 228).

Conforme Assafim: "Mais que isso, a estrutura dogmática e institucional do Sistema nacional não só estaria afeita a um controle mais intenso das condutas em geral, como, até mesmo justificaria a adoção de uma espécie de sistema de isenção por categoria de acordos como ferramenta de descentralização da análise antitrust, nos moldes do artigo 81.3 do TCE e do Regulamento 1/2003 e, por exemplo, poder-se-ia instituir resoluções como o que ocorre com o advento do Regulamento (CE) Ns. 240/96 e 772/2004, haja vista a possibilidade de autorizações ou isenções de maneira análoga mediante o emprego combinado do art. 27 com outras disposições da LDC, incluindo entre elas o artigo 54" (ASSAFIM, J. M. A Transferência de Tecnologia no Brasil Aspectos Contratuais e Concorrenciais da Propriedade Industrial, p. 300).
} 
Esclarecendo, não se estaria diante de hipótese de definição de ilícitos per se ou de afastamento do poder de julgamento dos órgãos do SBDC. Trata-se de aplicação do próprio modelo da razão. O que propomos é espécie de regulamento de isenção por categoria que definiria que determinadas cláusulas usuais em contratos de transferência de tecnologia são presumidamente lícitas dados os efeitos de eficiência compensatória indicados no art. 54 da Lei 8.884/94.

Como expõe Forgioni, a moeda de troca da certeza e segurança jurídicas da autorização é a renúncia a maior flexibilidade negocial. "A segurança e a previsibilidade são apanágios dos negócios que obedecerem ao texto do regulamento de isenção, porque se sabe de antemão que estarão imunes de contestação antitruste."

Enquanto um sistema de controle a posteriori das condutas proporciona maior grau de liberdade dos agentes econômicos, o controle prévio promove a segurança jurídica, a previsibilidade, incentiva as contratações e, tendo em vista as questões impostas pelo TRIPS, conseguirá atender à necessidade de verificação sistemática destas contratações.

\subsection{Recomendação de Criação de Regulação Administrativa Específica para Contratos de Transferência de Tecnologia}

\subsubsection{Análise da experiência recente internacional dos países em desenvolvimento}

Cuidar de aspectos concorrenciais da propriedade intelectual na legislação nacional não é tarefa fácil para os países em desenvolvimento. Há atualmente quatro modelos diferentes sendo adotados: (i) modelo liberal; (ii) modelo de proibição; (iii) modelo da regra da razão simples e (iv) modelo híbrido.

O modelo liberal é o adotado por Hong Kong, Guatemala e Jamaica. Hong Kong e Guatemala seguem uma política de não-intervencionismo sem regulação específica no campo da exploração da propriedade intelectual e o direito concorrencial. As restrições em acordos de transferência de tecnologia são aceitas desde que estabelecidas em consenso entre

\footnotetext{
${ }^{507}$ FORGIONI, P. Os Fundamentos do Antitruste, p. 220.
} 
as partes (Hong Kong). Na Jamaica, a lei antitruste estabelece absoluta imunidade para atividades relativas a propriedade intelectual e transferência de tecnologia. ${ }^{508}$

Já o modelo de proibição, é similar à posição adotada pelos países em desenvolvimento (inclusive na América Latina) nos anos 1970 e 1980. Apesar de não terem legislação antitruste, os países aplicam uma proibição quase per se para várias restrições. Exemplo desse modelo são as Filipinas. Na Lei de Propriedade Industrial Filipina, há quatorze restrições, análogas às quatorze restrições proibidas do TOT Code. As restrições são proibidas, por serem consideradas prima facie como tendo um efeito adverso na concorrência e no comércio. A Lei de Propriedade Industrial Filipina ainda inclui cláusulas mandatórias a serem incluídas em contratos de transferência de tecnologia, a fim de proteger licenciados. ${ }^{509}$. 510

Quanto ao modelo da regra da razão simples, as práticas anti-competitivas são analisadas caso a caso, claramente com base no modelo adotado por países desenvolvidos. Para facilitar a aplicação do modelo, Coréia do Sul, Taiwan e Cingapura promulgaram diretrizes nos moldes da opção efetuada pelos EUA, União Européia e Japão. ${ }^{511}$ As diretrizes reiteram a questão da falta de presunção de poder de mercado dos titulares dos direitos de propriedade intelectual, efeitos pró-competitivos do licenciamento e análises profundas dos contextos das práticas. A regulação da Coréia do Sul e de Taiwan baseiam-se amplamente no Regulamento 240/96 da Comissão Européia, anterior ao atualmente em vigor (Regulamento 772/04), incluindo cláusulas "pretas" e "brancas" na listagem que efetuam. A aplicação do modelo da regra da razão requer bastante experiência e capacidade das autoridades

\footnotetext{
${ }^{508}$ Jamaica: www.jftc.com/TheFCA/theact/Theact.htm. - promulgado em 1993 e alterado em 2001 - vide arts. 3) c), 20 2) b) e 263 ).

509 NGUYEN, T. T. The CFI's Ruling in Microsoft v. Commission, p. 576 e ss. esclarece que as opiniões emitidas pela Suprema Corte Filipina demonstraram que os direitos exclusivos dos detentores de direitos de propriedade intelectual não são absolutos e devem ser limitados a fim de proteger o interesse público e a livre concorrência. A Suprema Corte baseia-se nas exceções do TRIPS.

${ }^{510}$ Vale ressaltar que o Canadá se empenhou em estabelecer um acordo bilateral de investimento com as Filipinas. Conforme Artigo V(2) (e) do BIT Canadá/Filipinas de 1995:

"Nenhuma das Partes Contratantes poderá impor quaisquer das exigências seguintes em relação a permitir o estabelecimento ou aquisição de um investimento ou exercitar quaisquer das seguintes exigências em relação à subseqüente regulação do referido investimento;

$[\ldots]$

(e) a transferir tecnologia, um processo produtivo ou outro conhecimento proprietário a uma pessoa em seu território não afiliada ao transferente, exceto quando a exigência for imposta ou a obrigação ou compromisso for imposto por uma corte, tribunal administrativo ou autoridade da concorrência, seja para remediar uma alegada violação das leis da concorrência ou agindo de forma não inconsistente com as cláusulas deste contrato".

${ }^{511}$ Coréia do Sul: www.ftc.go.kr/eng/index.html (menciona expressamente em seu prefácio a regulação européia, americana e japonesa); Taiwan: www.ftc.gov.tw/EnglishWeb/English.html; Cingapura: www.ccs.gov.sg/Guidelines/Index.html (cópia do Regulamento 772/2004 da Comissão Européia). Conforme NGUYEN, T. T. The CFI's Ruling in Microsoft v. Commission, p. 573.
} 
encarregadas. Nguyen considera esse modelo adequado somente para os países desenvolvidos. $^{512}$

O modelo híbrido proposto por Nguyen $^{513}$ para os países em desenvolvimento seria uma mistura dos anteriores, delineado caso a caso conforme a situação econômica, política, social e institucional do país. Imprescindível é que se faça uso das exceções à concorrência invocadas no TRIPS, a fim não somente de controlar as práticas anticompetitivas, mas também para encorajar a transferência de tecnologia. $\mathrm{O}$ autor alerta para obstáculos internos e externos da regulação nos países em desenvolvimento.

São obstáculos internos: (i) falta de capacidade das autoridades regulatórias, principalmente para a análise econômica necessária à intersecção propriedade intelectual antitruste; (ii) deficiência da legislação - ausência de diretrizes para aplicação da intersecção propriedade intelectual - antitruste na maioria dos países em desenvolvimento; (iii) ausência de uma cultura de concorrência ou de uma ideologia sócio-econômica de concorrência, especificamente relacionada à propriedade intelectual, a opinião pública foca demasiadamente na quantidade e qualidade das tecnologias importadas, tenta aumentar o investimento estrangeiro direto como prioridade ${ }^{514}$ e (iv) ausência de cooperação entre os órgão da propriedade intelectual e da concorrência - alertando para a necessidade de uma regulação vinculante para a cooperação entre os órgãos, gerando desentendimento sobre o campo de atuação de cada qual. ${ }^{515}$

Como obstáculo externo para a regulação Nguyen cita especificamente o poder de pressão das corporações transnacionais sobre os seus próprios governos os quais, conseqüentemente, pressionam os governos dos países em desenvolvimento. Assim, quando da aplicação da restrição aos direitos de propriedade intelectual, mesmo que baseadas na legislação de concorrência, os países em desenvolvimento certamente sofreram pressão por

\footnotetext{
${ }^{512}$ NGUYEN, T. T. The CFI's Ruling in Microsoft v. Commission, p. 579.

${ }^{513}$ NGUYEN, T. T. The CFI's Ruling in Microsoft v. Commission, p. 579 e ss.

${ }^{514}$ Exemplificativamente, Nguyen cita o relatório do Comitê de Revisão da Política de Concorrência que expõe Hong Kong como país atualmente sofrendo com práticas anti-competitivas de grandes corporações, particularmente excluidoras e exploradoras, que têm gerado abusos no exercício do poder de mercado. Conclui que o local de maior sucesso da política "laissez-faire" está precisando de concorrência (NGUYEN, T. T. The CFI's Ruling in Microsoft v. Commission, p. 575).

${ }^{515}$ Vide ICTSD - International Centre for Trade and Sustainable Development. Intellectual Property and Competition Law - Exploring Some Issues of Relevance to Developing Countries, p. xi e 2.
} 
parte dos países desenvolvidos. ${ }^{516}$ Instrumentos de pressão, além de painéis da OMC, são também os acordos de investimentos bilaterais, conforme analisamos no Item 1. supra e no Capítulo I Item 6.3.

\subsubsection{Proposta para o Brasil}

Conforme analisamos ao longo do Capítulo II e deste Capítulo III, a atuação do INPI em relação aos contratos de transferência de tecnologia fundamenta-se na execução das normas atinentes à propriedade industrial tendo em vista sua função social, econômica, jurídica e técnica ${ }^{517}$ e, especificamente, na política industrial e tecnológica aprovadas pelo Governo Federal. ${ }^{518}$

Assim, a competência do INPI estende-se àquilo que for (i) objeto direto da propriedade industrial e (ii) delineamento específico da política industrial do Governo Federal. ${ }^{519}$ Delimitamos, assim, a moldura da atuação do INPI.

Contratos de transferência de tecnologia contém usualmente cláusulas que protegem a tecnologia contra o abuso pela parte recipiente, cláusulas restritivas que controlam a liberdade de ação do recipiente ao aplicar a tecnologia. Alterar-se a faculdade do titular de impor essas restrições, regulando-as, é tarefa que exige bastante ponderação, a fim de não

\footnotetext{
${ }^{516} \mathrm{O}$ autor cita especificamente os casos da Argentina contra os EUA referente à proteção por patentes e de dados de testes (WT/DS196/1 6 de junho de 2000) e do Brasil contra os EUA referente à exigência de exploração local (WT/DS199/4). NGUYEN, T. T. The CFI's Ruling in Microsoft v. Commission, p. 583 e ss.

${ }^{517}$ Lei 5.648/70, art. $2^{\circ}$.

${ }^{518}$ Decreto 5.147/04 “Aprova a Estrutura Regimental e o Quadro Demonstrativo dos Cargos em Comissão e das Funções Gratificadas do Instituto Nacional da Propriedade Industrial - INPI, e dá outras providências - , Anexo I - Estrutura Regimental do Instituto Nacional da Propriedade Industrial Capítulo I - Da Natureza e Finalidade Art. $1^{\circ} \mathrm{O}$ Instituto Nacional da Propriedade Industrial - INPI, autarquia federal criada pela Lei 5.648, de 11 de dezembro de 1970 e vinculada ao Ministério do Desenvolvimento, Indústria e Comércio Exterior, com sede e foro no Distrito Federal, tem por finalidade principal executar, no âmbito nacional, as normas que regulam a propriedade industrial, tendo em vista a sua função social, econômica, jurídica e técnica, bem como pronunciarse quanto à conveniência de assinatura, ratificação e denúncia de convenções, tratados, convênios e acordos sobre propriedade industrial, conforme o art. 240 da Lei 9.279, de 14 de maio de 1996. [...]

Art. 13. À Diretoria de Contratos de Tecnologia e Outros Registros compete:

I - analisar e decidir quanto à averbação de contratos para exploração de patentes, uso de marcas e ao que implique transferência de tecnologia e franquia, na forma da Lei 9.279, de 1996, de modo alinhado às diretrizes de política industrial e tecnológica aprovadas pelo Governo Federal; [...]" (grifos nossos).

${ }^{519}$ Quanto aos limites da própria política industrial, conforme colocado por Salomão Filho, a política industrial não pode ser erigida para substituir ou eliminar o sistema concorrencial (SALOMÃO FILHO, C. Direito Concorrencial - As Estruturas, p. 208).
} 
anular totalmente a vantagem competitiva do titular. Porém, é, também, o modo de influir na absorção e difusão do conhecimento.

Argüir-se que "a existência de um contrato de transferência de tecnologia, ainda que com restrições de uso e limitações territoriais, é melhor do que nenhum contrato" deve ser analisado com cuidado. O fato da Comissão Européia adotar regulamento específico para essas operações desde meados da década de oitenta (80) nos faz inferir que são operações sensíveis e relevantes, sim, para a economia de um país, conforme expomos no Capítulo I.

O TRIPS impôs limites a esta regulação. ${ }^{520}$ A limitação, está na necessidade das medidas serem "compatíveis com o TRIPS", "apropriadas" e "necessárias para evitar ou controlar as práticas". Os princípios fundamentais dos acordos relativos à OMC também se aplicam, tais como tratamento nacional, exceção da nação mais favorecida e transparência. A regulação da transferência de tecnologia protegida por segredo de negócio não poderá distinguir entre a importação de tecnologia e a tecnologia obtida localmente no mercado interno. De certa forma, coíbe-se assim a intenção que existia na regulação latino-americana de compensar o desnível tecnológico norte-sul fortalecendo a posição do receptor latinoamericano. Ademais, limitações específicas para contratos entre empresas pertencentes ao mesmo grupo econômico, com vinculação majoritária de capital, restam prejudicadas, pois sua relevância sob a perspectiva concorrencial é reduzida.

Ponto importante é que tecnologia dentro da moldura do TRIPS refere-se tão somente a tecnologia protegida por propriedade intelectual. Entre os contratos analisados sob o presente trabalho, o termo, para fins do TRIPS, engloba, portanto, somente tecnologia protegida por segredo de negócio, que seja confidencial. Assim, em não existindo confidencialidade da tecnologia, o TRIPS não se aplica.

A fim de fundamentar as práticas restritivas a serem aceitas ou não em contratos de transferência de tecnologia para o Brasil, é preciso adotar raciocínio diferente do usual para as restrições de negócios e sua análise concorrencial. Ao invés de tolerar o monopólio ou a concentração de poder entendendo-os como resultado dos direitos de propriedade intelectual, para algumas cláusulas específicas defende-se justamente uma postura mais restritiva às limitações contratuais impostas pelo fornecedor da tecnologia do que o próprio direito da concorrência imporia. Não se trata de imunizar o segredo de negócio da aplicação 
da regra concorrencial e sim de limitar as práticas negociais a ele relacionadas ainda mais do que o direito concorrencial limitaria. Ao tratar de limites em relação a (i) exclusividade de uso e (ii) limitação de uso da tecnologia após prazo contratual; lidamos, no caso do segredo de negócio, com a confidencialidade da informação e seu controle, com os limites mesmo de proteção da propriedade industrial e não com o seu exercício. Estamos, portanto, na esfera de competência do INPI. ${ }^{521}$

Logo, defendemos a continuidade de aplicação pelo INPI do conceito de transferência de tecnologia ao contrato de fornecimento de segredo de negócio, quando de seu registro. O conceito de "transferência" de tecnologia, conforme revimos no Capítulo I Item 4.2, opõe-se ao conceito de sua "licença". Impor esse conceito implica, tratando-se de segredo de negócio, garantir que o receptor da tecnologia tenha plena capacidade de utilizar o segredo de negócio após o término do prazo contratual, promovendo-se, assim, a disseminação da transferência de tecnologia no território.

Dentro do conceito de "transferência" acima introduzido, há diversas variáveis possíveis. Quanto à exclusividade de uso, pode-se:

Limitá-la à pessoa do receptor, durante o prazo do contrato;

(i) Permitir a transmissão do conhecimento pelo receptor a terceiros, ainda durante o prazo contratual e mediante contrato de confidencialidade, como forma de subcontratação para a fabricação de parte dos ou dos produtos/prestação de serviços;

(ii) Limitá-la à pessoa do receptor, durante o prazo do contrato, e abrir a possibilidade de uso por terceiros, mediante confidencialidade, após o prazo do contrato;

(iii) Dentro do item (iii), somente permitir a transmissão a terceiros dentro de determinado período, após o prazo do contrato. ${ }^{522}$

Quanto à confidencialidade, temos as seguintes possibilidades principais:

(i) Permiti-la somente durante o prazo contratual;

\footnotetext{
${ }^{521}$ Isto é, a execução das normas atinentes à propriedade industrial tendo em vista sua função social, econômica, jurídica e técnica (Lei 5.648/70, art. $2^{\circ}$ ).

${ }_{522}$ Dentre as hipóteses apresentadas, há uma possibilidade grande de variações. Por exemplo, ao invés de subcontratação, permitir o uso integral por terceiros autorizados pelo receptor como forma de cobrir mesmo parte do território que ele não conseguir explorar.
} 
(ii) Permiti-la por prazo determinado após o prazo contratual;

(iii) Permiti-la por prazo indeterminado após o prazo contratual.

A confidencialidade se interrelaciona intrinsecamente com a exclusividade de uso. Por exemplo, é possível interpretar-se uma cláusula de exclusividade como proibidora da transmissão do conhecimento a terceiros por meio de subcontratação. ${ }^{523}$ Porém, extinta a obrigação de confidencialidade, extingue-se a exclusividade daquela parte do conhecimento que agora é de acesso ilimitado a todos.

Propondo (ou sugerindo a manutenção) da ingerência do INPI sobre os prazos de confidencialidade da tecnologia, não estamos lidando com algo esdrúxulo ou sem precedentes internacionais. Para os contratos de know-how, o próprio Regulamento 240/96 da Comissão Européia estabelecia: ${ }^{.24}$

Tendo em conta a dificuldade de determinar quando é que o saber-fazer deixa de ser secreto, convém, no que diz respeito aos territórios em que a tecnologia licenciada só abrange o saber-fazer, limitar a um certo período a validade de tais obrigações. Além disso, para garantir suficientes períodos de protecção, convém fixar o início desses períodos a partir da data em que o produto é comercializado pela primeira vez por um dos licenciados no interior da Comunidade.

O prazo máximo imposto pelo Regulamento $240 / 96$ era de dez (10) anos. ${ }^{525}$ Entendemos que a questão da determinação do prazo de confidencialidade que é razoável está relacionada com o ciclo de vida da tecnologia e dos produtos/serviços respectivos.

Um ponto importante a ser considerado pelo INPI é a questão da tecnologia não secreta, portanto, não protegida por segredo de negócio. É fato que a tecnologia tem de ser secreta ou "de não fácil acesso" para se beneficiar das isenções de aplicação do art. 81, inciso 1, do Tratado de Roma. ${ }^{526}$ Conforme comentamos no Capítulo II, Item 2.3.3, aceitar ou não esse tipo de contrato para registro é algo que o INPI deve medir dentro da sua discrição de determinar aquilo que é transferência de tecnologia. Entendemos que nesta hipótese, a atuação do INPI quando do registro do contrato estaria legitimada para: (i) classificar e enquadrar corretamente a contratação como serviços técnicos, já que o conteúdo de transferência de

\footnotetext{
${ }^{523}$ A redação da cláusula contratual é importante e deve ser precisa quanto às obrigações.

${ }^{524}$ Nota de margem 13. O Regulamento pode ser consultado no Diário Oficial 1996 L 31/2.

${ }^{525}$ Art. $1^{\circ}$, inciso 6, do Regulamento 240/96.

${ }^{526}$ Regulamento 240/96, art. 10 Inciso I; Regulamento 772/04 Art. 1 Inciso 1 letra i) alínea (i).
} 
tecnologia estaria no ensinar a aplicação prática da tecnologia e não no transmitir a tecnologia já pública, e (ii) controlar e eventualmente eliminar cláusulas de confidencialidade que estejam presentes no instrumento contratual.

Ponto interessante da Regulação da Comissão Européia e que poderia ser adotado no Brasil é a necessidade de, em se tratando de contrato de know-how, cessar-se imediatamente o pagamento a partir do momento em que ele se tornar de conhecimento geral. ${ }^{527}$ Curiosamente, se o know-how vem a público por culpa do receptor da tecnologia, o titular deve poder continuar cobrando os pagamentos contratuais até o final do contrato, sem prejuízo da sua capacidade de rescindir o contrato. ${ }^{528}$

A propriedade industrial e seu exercício - incluindo o exercício da posição da fato conferida pelo segredo de negócio inserto em contrato de transferência de tecnologia - tem usualmente por objetivo "aumentar a produtividade, melhorar a qualidade de bens ou serviço, bem como propiciar a eficiência e o desenvolvimento tecnológico ou econômico."

Entretanto, vale ressaltar que a melhoria tecnológica não é apta a justificar, por si só, a conduta. Requisitos adicionais, previstos na própria lei, devem estar presentes: (i) que os benefícios sejam distribuídos equitativamente aos participantes, consumidores e usuários finais; (ii) não impliquem a eliminação da concorrência de parte substancial do mercado relevante de bens e serviços e (iii) sejam observados os limites estritamente necessários para atingir os objetivos visados. Aplicando-se o interesse da coletividade de difusão e absorção da tecnologia em território brasileiro, encontramos na própria Lei 8.884/94 a instrumentalização da concorrência necessária para a regulação do contrato de transferência de tecnologia. ${ }^{529}$

Nosso posicionamento é pela necessidade de cooperação entre o INPI e o SBDC a fim de atingir-se uma regulação do assunto que seja satisfatória para atender aos interesses nacionais. ${ }^{530}$ A revisão pelo INPI dos contratos de transferência de tecnologia ocorre antes do

\footnotetext{
${ }^{527} \mathrm{Ou}$, em havendo interesse comercial do receptor da tecnologia, atentar para a necessidade de se alterarem os termos do contrato. É fato notório que a divulgação da tecnologia secreta diminui consideravelmente o seu valor.

${ }^{528} \mathrm{E}$, acrescente-se, cobrar perdas e danos e/ ou multa contratual (se houver) pela divulgação indevida.

${ }^{529}$ Lei 8.884/94; art. 54.

${ }^{530}$ Conforme a Lei que regula o processo administrativo no âmbito da Administração Pública Federal, Lei 9.784/99:

"Capítulo VI da Competência:

Art. 11. A competência é irrenunciável e se exerce pelos órgãos administrativos a que foi atribuída como própria, salvo os casos de delegação e avocação legalmente admitidos.
} 
contrato produzir efeitos em relação a terceiros. Já a análise concorrencial pela regra da razão sob o art. 54 da Lei 8.884/94 ocorre em até quinze dias de sua assinatura. A aprovação do contrato pela autoridade concorrencial não é, em princípio, condição para sua eficácia, o que ocorre no registro do contrato pelo INPI. Logo, todo contrato de transferência de tecnologia passará necessariamente pelo INPI, já no caso da análise pelo SBDC, há uma discricionariedade e até assunção de risco pela parte, o que poderá fazer com que muitos contratos potencialmente nocivos nem cheguem a seu conhecimento.

É perfeitamente possível a coordenação das atividades de ambos os órgãos administrativos. O INPI teria a competência de verificar a presença de algumas condutas, dada a competência do órgão de registrar esses contratos para que produzam efeitos em relação a terceiros e "executar as normas que regulam a Propriedade Industrial, tendo em vista sua função econômica, social, jurídica e técnica."

O Regulamento de isenção por categoria da Comissão Européia tem a intenção de permitir às partes concluir contratos de transferência de tecnologia com relativa segurança quanto à aceitabilidade de suas cláusulas sob o ponto de vista concorrencial. Trata-se de conseguir segurança e previsibilidade para as contratações. A intenção do regulamento de isenção por categoria é isentar automaticamente alguns tipos de contratos do escopo do art. 81, inc. I, do Tratado de Roma, sem a necessidade de se individualmente considerar os efeitos anti-competitivos e pró-competitivos da prática restritiva (i.e. balanceamento com o art. 81, inciso 3, do mesmo Tratado). Isto facilita a atribuição dos órgãos e instâncias envolvidos na aplicação do direito da concorrência. ${ }^{531}$

Dessa forma, o Regulamento 772/04 da Comissão Européia não institui restrições anticoncorrenciais "per se". Ele descreve restrições que usualmente são problemáticas do ponto de vista concorrencial e outras restrições que não apresentam qualquer preocupação do ponto de vista concorrencial, baseada na prática da Comissão e do Tribunal Europeu na análise das restrições contidas nesses contratos. Aquelas restrições que considera "graves" são indicadas pela Comissão Européia como ensejadoras de uma análise do contrato integral,

Art. 12. Um órgão administrativo e seu titular poderão, se não houver impedimento legal, delegar parte da sua competência a outros órgãos ou titulares, ainda que estes não lhe sejam hierarquicamente subordinados, quando for conveniente, em razão de circunstâncias de índole técnica, social, econômica, jurídica ou territorial. [...] Art. 35. Quando necessária à instrução do processo, a audiência de outros órgãos ou entidades administrativas poderá ser realizada em reunião conjunta, com a participação de titulares ou representantes dos órgãos competentes, lavrando-se a respectiva ata, a ser juntada aos autos."

${ }^{531}$ DOLMANS, M.; PIILOLA, A. The Proposed New Technology Transfer Block Exemption, p. 541. 
individualmente, pela Comissão Européia. Já aquelas restrições consideradas “excluídas”, são consideradas pela Comissão Européia como sujeitas, individualmente (i.e. não o contrato integral) à revisão específica pela Comissão Européia, sob pena de poderem ser consideradas nulas de pleno direito. Logo, otimiza-se o trabalho da autoridade concorrencial.

Propomos que o INPI, quando do registro do contrato de transferência de tecnologia, verifique a presença de determinadas restrições de negócio potencialmente danosas, conforme estiver estabelecido em diretrizes conjuntas dos dois órgãos - INPI e CADE. Em estando presentes, caberá às partes decidir sobre: (i) excluí-las do contrato ou (ii) submetê-la ao SBDC para análise de razoabilidade sob o art. 54 da Lei 8.884/94. O rol de cláusulas que ensejará esse procedimento é reduzido, pois se trata de restrições que usualmente causam apreensão do ponto de vista concorrencial, não bastasse estarem inseridas em documento atinente à propriedade industrial.

A fim de não prejudicar a agilidade do registro do contrato pelo INPI, nem da sua eficácia perante terceiros, entendemos que caberá ao INPI incluir no Certificado de Averbação que emitir a devida observação quanto à cláusula e a necessidade de submissão ao CADE para verificação, conforme o regulamento/diretriz em vigor. ${ }^{532} \mathrm{E}$ o encaminhamento de ofício de cópia do processo de registro ao SBDC, com os comentários que julgar pertinentes. As diretrizes para esse controle preventivo podem e devem ser elaboradas em conjunto com o SBDC, dada a especialização de ambos os órgãos, cada qual em sua matéria. Está-se diante de diretrizes concorrenciais, mas com cunho de absorção e disseminação de tecnologia, conforme vier a ser previsto em política industrial e tecnológica do país e dentro da moldura do TRIPS.

Nesse ponto, há de se diferenciar entre uma política de concorrência focada na inovação e uma política de concorrência focada na disseminação.

Conforme Ullrich, os efeitos da política de concorrência que foca excessivamente no não impedimento da inovação se esquecem de que o bônus que se concede hoje à inovação implicará um preço no futuro.

\footnotetext{
${ }^{532} \mathrm{O}$ art. $54 \S 4^{\circ}$ estipula o prazo, "dentro de quinze dias úteis de sua realização" para qu a parte submeta o ato ao CADE. Entendemos que este prazo deveria, então ser contado a partir da retirada do Certificado de Averbação do INPI pela parte.
} 
O licenciante é visto como o senhor do jogo e o licenciado como um adotador ou, nos melhores casos, adaptador. Porém, esta aproximação ignora a possibilidade de que o licenciado pode transformar a tecnologia licenciada a fim de adaptá-la às suas próprias necessidades e àquelas do segmento de mercado em que opera; ou ainda, que ele pode diversificar sua aplicação, desenvolvendo seu potencial, e criando valor agregado contribuindo com tecnologia complementar ou know-how de serviço próprio. ${ }^{533}$

Nos países em desenvolvimento, a inovação é baseada principalmente em melhorias que fazem um acréscimo a tecnologias existentes, mais do que em contribuições originais para o estado atual do conhecimento. A informação não é só efeito do seu processo de produção, a informação é também condição de seu processo de produção. Assim, a sociedade seria beneficiada se os competidores tivessem a permissão de aperfeiçoar a inovação, após utilizá-la.

O atual foco da política concorrencial de contratos de transferência de tecnologia na Europa segue a tendência iniciada pelos Estados Unidos e refletida nas diretrizes "Antitrust Guidelines for the Licensing of Intellectual Property". ${ }^{534}$ A intenção da análise antitruste é reforçar os incentivos do licenciante de inovar. Como ferramentas, tem-se: (i) definição estreita do receptor como um potencial competidor e (ii) definição ampla dos ganhos de eficiência a serem esperados de termos restritivos de licença, em termos de potenciais de lucro e oportunidades de melhorias, que são considerados gerados primordialmente, se não exclusivamente, pelo fornecedor. ${ }^{535}$

${ }^{533}$ ULLRICH, H. Expansionist Intellectual Property Protection and Reductionist Competition Rules: a TRIPS Perspective, p. 751.

534 Disponível em: <http://www.usdoj.gov/atr/public/guidelines/ipguide.htm>. Acesso em: 27/12/2009. Conforme palestra apresentada pelo Departamento de Justiça dos Estados Unidos em 01/04/2004:

"[...] É importante reconhecer que as exportações baseadas em propriedade intelectual [...] são as exportações número 1 deste país e, como tais, sua criação e proteção é critica para uma economia vibrante. [...] diferenças entre as regras de licenciamento entre as nações têm o potencial de corromper o comércio transfronteira. Como resultado, os EUA têm um interesse importante e justificado nas escolhas que outras jurisdições fazem sobre como suas autoridades antitruste analisarão as restrições que aparecem em transações de licenciamento de propriedade intelectual. Os Estados Unidos adotaram Diretrizes Antitrust para a licença de propriedade intelectual em 1995, adotando uma aproximação baseada sistematicamente em efeitos econômicos para a avaliação [...] Um ano depois, a Comissão Européia adotou o seu Regulamento de Isenção em Bloco ("TTBE") corrente, o qual foca fortemente em uma aproximação estrutural para o exame dos contratos de licença de transferência de tecnologia. Em seu trabalho recente de revisão do TTBE, e na minuta de um novo documento, as Diretrizes para Licenciamento de Tecnologia, a Comissão afastou-se daquela interpretação estrutural e abraçou um modelo baseado nos efeitos econômicos. Conseqüentemente, estamos satisfeitos que a adoção do TTBE e a emissão de respectivas Diretrizes moverão a União Européia e os Estados Unidos de forma significativa para uma convergência em nossa análise antitruste de contratos de licença de direitos de propriedade intelectual. Este é um desenvolvimento bem-vindo pela economia global que vivemos hoje, e nós parabenizamos o Membro da Comissão Monti e a Comissão Européia pelos seus esforços nesta área" (nossa versão do inglês) (grifamos). Disponível em: <http://www.justice.gov/atr/public/speeches/203228.htm>. Acesso em: 03/01/2010.

${ }_{535}$ ULLRICH, H. Expansionist Intellectual Property Protection and Reductionist Competition Rules: a TRIPS Perspective, p. 750. 
Esta aproximação, do ponto de vista do TRIPS, implica em muito mais do que estender a política da concorrência relativa à propriedade intelectual às práticas restritivas de acordos. Ullrich entende que estamos nos deparando com um

[E]sforço concertado em mercados maiores a fim de permitir que contratos de licença restritivos reforcem a proteção das oportunidades e lucros da inovação com base na propriedade intelectual, visando melhorar a capacidade produtiva $\mathrm{e}$ inovativa do titular do direito de propriedade intelectual e encorajar o licenciado a embarcar nesta situação e cooperar com os projetos do primeiro. ${ }^{536}$

A aplicação do modelo da regra da razão para cláusulas restritivas em contratos de licenciamento requer bastante experiência e capacidade das autoridades encarregadas. Nguyen considera esse modelo adequado somente para os países desenvolvidos. ${ }^{537}$ Uma política de concorrência focada na disseminação da tecnologia deveria deparar-se com maior cuidado nas seguintes práticas: (i) cláusulas de retrolicença ou que imponham o dever de cessão pelo receptor de melhorias e desenvolvimentos que fizer à tecnologia ao fornecedor; (ii) proibição de contestação da validade da proteção da informação em juízo; ${ }^{538}$ (iii) restrições à pesquisa e desenvolvimento pelo receptor, bem como restrições do receptor de explorar a sua própria tecnologia; (iv) fixação de preços pelo fornecedor ao receptor (preços relativos ao produto ou serviço que incorporam a tecnologia - mínimos, máximos, sugestões de preços, restrições de descontos); (v) limitação de quantidade máxima de produção e de comercialização dos produtos; (vi) divisão de mercados ou cliente, inclusive proibição de vendas ativas ou passivas

Já quanto ao estabelecimento de participações de mercado como critério para eximir de análise as contratações relativas à propriedade industrial, ${ }^{539}$ a doutrina européia e os debates promovidos à época da instituição do novo Regulamento levantaram o fato de que se

\footnotetext{
${ }^{536}$ ULLRICH, H. Expansionist Intellectual Property Protection and Reductionist Competition Rules: a TRIPS Perspective, p. 752. Conforme Comparato (2006, p. 343)" [...] a apropriação do saber tecnológico pelo empresário capitalista é o grande fator de concentração de poder em suas mãos, poder que, ao criar um mercado mundial, transforma o conjunto das relações e instituições sociais nos quatro cantos da Terra.”

${ }^{537}$ NGUYEN, T. T. The CFI's Ruling in Microsoft v. Commission, p. 579.

${ }^{538}$ A Comissão Européia, curiosamente, optou por incluir no rol de cláusulas brancas esta faculdade do receptor quando inserida em contratos envolvendo segredo de negócio. A restrição teria o efeito de promover a licença de tecnologias em geral, titulares de tecnologia mais fracos economicamente teriam a coragem de licenciar o seu segredo de negócio a receptores mais fortes economicamente, sem temer que estes a contestem, uma vez absorvido o conhecimento. O raciocínio fará mais ou menos sentido para o Brasil analisando-se a situação dos titulares brasileiros de tecnologia e as restrições de prazos de confidencialidade a serem aplicadas à contratação. Resta claro que se trata de ponto que lida com o exercício do direito e, portanto, sujeito à regulação de cunho concorrencial.

${ }^{539}$ Conforme a inovação trazida pelo Regulamento 772/04 da Comissão Européia, que significou uma tendência de harmonização em relação às Diretrizes americanas.
} 
trata de elemento causador de incerteza para as partes contratuais, por ser difícil de aplicar. A definição de mercados relevantes em tecnologia é difícil, especialmente em produtos inovadores. Alega-se também que debruçar-se sobre participações de mercado é uma forma de olhar para trás e não para a frente, onde deveria estar o foco no caso de mercados de tecnologia e inovação. Estima-se que o mais relevante nesse mercado não seja quantas empresas atualmente vendem produtos no mercado, mas sim quantas empresas têm o potencial de ameaçar a posição do licenciante. Outra crítica da adoção desse critério é o fato de o direito concorrencial já prever uma análise específica sob o crivo de abuso de posição dominante. ${ }^{540}$

Entendemos que para o Brasil e a política de concorrência focada em disseminação que defendemos, a aproximação de uma eventual regulação específica com o Regulamento anteriormente aplicado pela Comissão Européia (Regulamento 240/96), com foco mais estrutural (no sentido de condutas estruturantes do contrato) ${ }^{541}$ e menos econômico, seria o adequado.

O fato é que uma política de concorrência com a intenção de promover a disseminação e absorção de tecnologia não pode ser tarefa para as autoridades da área concorrencial, somente. ${ }^{542}$

Propomos no início desse Item a atuação do INPI quanto à extensão das faculdades atribuídas ao titular do segredo de negócio. Lembramos no Capítulo II que a Coordenação de Imigração do Ministério do Trabalho e Emprego adota diretrizes importantes para absorção e disseminação de tecnologia ao vincular a concessão de visto de assistência técnica e sua prorrogação ao treinamento de mão-de-obra especializada brasileira. ${ }^{543} \mathrm{O}$ balanceamento ideal entre concorrência e propriedade industrial na transferência de tecnologia poderá ser alcançado com uma diversidade de políticas e regimes, desde que se adote um vetor comum baseado no interesse coletivo da difusão e absorção de tecnologia.

\footnotetext{
${ }^{540}$ Conforme DOLMANS, M.; PIILOLA, A. The Proposed New Technology Transfer Block Exemption, p. 541.

${ }^{541}$ Estrutural foi a qualificação utilizada pelo representante do DoJ americano para definir o Regulamento 240/96. Vide nota de rodapé 533.

${ }^{542}$ Conforme relatório do ICTSD emitido dentro do "Programa de Direitos de Propriedade Intelectual e Desenvolvimento Sustentável”, "a implementação de uma política de concorrência eficaz tende a requerer uma multiplicidade de atores institucionais [...] cooperação e coordenação entre várias agências poderá ser essencial para criar e manter um ambiente competitivo" ICTSD - International Centre for Trade and Sustainable Development, p. 26.

${ }^{543}$ Resolução Normativa 61/2004 do Conselho Nacional de Imigração, vide Capítulo II, Item 1.
} 
Conforme analisamos no Capítulo I, a intensificação de contratações de tecnologia não assegurará, por si só, que essas conexões internacionais trabalhem efetivamente como canais de difusão tecnológica, a intensidade do componente de aprendizado em cada transação deve ser valorizada. É preciso focar na intensidade do aprendizado e não no volume de contratos. Somente assim ocorrerá a difusão tecnológica. 


\title{
CONCLUSÃO
}

\begin{abstract}
En primer lugar, se registra el pasaje de una estructura ordenada desde lo alto a un esquema de autoordenación. El ordenamiento jurídico, que era un dato, se transforma en una elección. De hecho, del lado de la "demanda del derecho", el operador puede realizar una elección, expresando así un juicio sobre la "oferta del derecho" y "adquiriendo" el más conveniente. (...) La elección es admitida para la búsqueda de la mejor tutela o del derecho menos severo o de aquél más conveniente. Los derechos o las administraciones objeto de la elección son, entonces, puestos en competencia. La replica de mercado que así se produce no es completa. Los derechos o los administraciones derrotadas, en realidad, no fallan. Sin embargo, aquellos vencedores amplían su esfera de dominio, yendo más allá de los confines nacionales, en un proceso acumulativo típico de la empresa que adquiere una posición dominante. Habría que preguntarse si el cuasimercado que así se desarrolla tiene necesariamente por efecto la optimización del resultado. (...) no se puede excluir que, en otros casos, la búsqueda del derecho menos severo y de la mejor tutela pueda resolverse en la prevalencia del peor derecho. Se ilustra así un paradigma, el de la "mercantilización" de las instituiciones que desmiente el paradigma tradicional por el cual las instituciones se imponen a los particulares, constituyendo un prerrequisito al cual estos últimos deben necesariamente adaptarse. $^{544}$
\end{abstract}

Nossa proposta para o presente trabalho era a de comprovar que a atual regulação da contratação internacional de transferência de tecnologia no Brasil e inadequada ao atual contexto econômico e industrial do país. Expusemos que a regulação deve concentrar-se na absorção da técnica pela mão-de-obra local, sem desestimular o fornecedor estrangeiro. Pretendíamos convencer que ambos os objetivos podem ser atingidos com a (i) matização da regulação na área tributária e cambial e (ii) promoção de maior interatividade entre a regulação pela propriedade industrial e o direito concorrencial, que devem focar nos termos das contratações, direcionados a promover a difusão do conhecimento.

No primeiro Capítulo demonstramos que a transferência de tecnologia é a base para o desenvolvimento tecnológico. Muito além da dicotomia desenvolvimento autóctone versus importação de tecnologia, verificamos que a importação de tecnologia é, também, geradora de parte das condições precedentes para o desenvolvimento de inovação localmente. Também por meio dela é que um país alcança o estado da técnica mundial que lhe permitirá avançar tecnologicamente.

Concluímos, ademais, que componente-chave de qualquer processo de transferência de tecnologia é a efetiva transferência de habilidades e know-how intangível que

${ }^{544}$ CASSESE, S. La Crisis Del Estado. Buenos Aires: Abeledo-Perrot, 2003, p. 152 e 153. 
assegurem a capacidade produtiva. Nos países em desenvolvimento, a inovação é baseada principalmente em desenvolvimentos que fazem um acréscimo a tecnologias existentes, mais do que em contribuições originais para o estado atual do conhecimento.

O canal de transferência de tecnologia não é uma forma fácil de construir capacidade de inovação. Por meio deste, as conseqüências da transferência de tecnologia serão determinadas pelos objetivos gerais das corporações que contratam, os quais certamente não englobam a disseminação da tecnologia para potenciais concorrentes. Dentro do contexto de conflito tecnológico norte-sul ainda existente e que apresentamos no Capítulo I, a harmonização do direito da concorrência e da propriedade intelectual em torno do interesse coletivo concentra-se justamente na administração da intenção dos países detentores da tecnologia de manter o seu monopólio e acesso restrito à tecnologia e o dos países receptores de terem amplo acesso e utilização da tecnologia.

Logo, a intensificação de licenciamento de tecnologia, não assegurará, por si só, que essas conexões internacionais trabalhem efetivamente como canais de difusão tecnológica. A intensidade do componente de aprendizado em cada transação deve ser valorizada. A simples abertura das portas ao investimento estrangeiro realmente não gerará incremento da base tecnológica local.

Apesar de a transferência de tecnologia ser um objetivo fundamental de muitos instrumentos públicos internacionais, sua implementação e execução na prática ainda é um desafio. A Conferência das Nações Unidas sobre um Código de Conduta em Transferência de Tecnologia nasceu em 1974, como iniciativa que reconhecia o papel fundamental que a ciência e a tecnologia desempenham no desenvolvimento sócio econômico de todos os países e, em especial, na aceleração do desenvolvimento dos países menos desenvolvidos ou em desenvolvimento. Havia efetivamente nos anos sessenta e setenta interesse em regular-se a transferência internacional de tecnologia por meio de um código em que os países desenvolvidos e detentores de tecnologia colaborariam com o desenvolvimento das outras economias dos países em menor estágio de absorção tecnológica.

Ao longo da década de oitenta, assistimos a um desenvolvimento diferente no posicionamento desses países, que se intensifica na década de noventa. Há uma centralização de interesses justamente em torno dos particulares e não mais dos países. Explicam os países 
desenvolvidos que a propriedade industrial trata de interesses empresariais e não estatais, cujos interesses se poderia transigir muito dificilmente.

Partindo do deslocamento do centro de interesses dos países para os particulares, a moeda de troca para o fornecimento de tecnologia a países em desenvolvimento torna-se o respeito a padrões mínimos de propriedade intelectual e a liberalização do comércio. Na esteira da criação da Organização Mundial do Comércio executa-se acordos-pilastras desta organização, entre estes, o Acordo sobre Aspectos Comerciais dos Direitos de Propriedade Intelectual Relacionados ao Comércio (TRIPS).

Acordos internacionais assinados impõem limites à atuação do país e os compromissos assumidos em relação à proteção à propriedade intelectual é um desses limites.

A política de intensificação da transferência de tecnologia por meio de mecanismos internacionais depende não somente de políticas regionais e internacionais, mas também de políticas nacionais. É preciso analisar caminhos viáveis para as políticas dentro da moldura nacional e internacional existente.

Os mercados podem funcionar mal tanto quanto os governos interferem demais quanto quando interferem de menos. As políticas de desenvolvimento das últimas duas décadas estiveram obcecadas com a primeira categoria de erros de política, os erros de ação do Governo. Assim, os erros de omissão - excesso de regras, restrições ao livre comércio, repressão financeira - foram "desenfatizados", em parte como reação à grande ênfase dada nas políticas anteriores de substituição de importações. Recentemente, os Governos têm procurado uma estratégia melhor balanceada, pois que a liberalização e a privatização falharam em entregar a performance esperada. Políticas industriais propriamente formuladas têm um importante papel a desenvolver nestas estratégias. Assim, o desafio nos países em desenvolvimento não é redescobrir a política industrial, mas aprender novamente como utilizá-la, de forma mais eficaz. ${ }^{545}$

Em nossa análise do tratamento jurídico dos contratos de transferência de tecnologia no Brasil, empreendemos a tentativa de distinguir, a fim de permitir uma análise mais rigorosa e acadêmica, as normas aplicáveis de cada uma das diversas áreas do direito que entram em contato com a atividade: direito de propriedade industrial, normas cambiais e

\footnotetext{
${ }^{545}$ RODRIK, D. Industrial Policy for the Twenty-First Century, p. 27 e 36.
} 
tributárias e direito concorrencial. De nossa análise aponta um verdadeiro subsistema jurídico, composto por normas que se inter-relacionam. Resta claro que, a fim de funcionar e cumprir o seu papel, toda a regulação deve estar alinhavada e em perfeita harmonia, sob um único viés interpretativo. Não é o que ocorre, ainda hoje, no Brasil.

Ao longo do Capítulo II, demonstramos que a regulação existente para essas operações é inadequada porque se baseia em pontos atualmente irrelevantes para a economia e estágio de desenvolvimento do país e tem como conseqüência o desestímulo das operações de transferência de tecnologia.

O processo de desenvolvimento industrial brasileiro norteou-se basicamente em (i) proteção ao mercado interno, (ii) políticas de comércio exterior, (iii) políticas de financiamento de bens de capital (base de toda a indústria de transformação) e (iv) industrialização acelerada em setores específicos com participação do Estado na economia por meio de empresas estatais, a chamada política industrial desenvolvimentista de substituição de importações. A industrialização orientou-se no sentido de gerar capacidade produtiva com adoção de padrões tecnológicos relativamente atrasados e imposição de elevadas barreiras à entrada, impactando significativamente a capacidade do país de gerar, transferir e introduzir inovações tecnológicas.

A regulação da transferência de tecnologia que acompanhou o processo de industrialização brasileiro tinha como vetores principais a substituição de importações paralelamente a controles fiscais e cambiais dos pagamentos das contratações, como forma de promover o equilíbrio da balança de pagamentos do país. Esta permanece em vigor, com alterações mínimas. Faz-se necessária revisão desta legislação e faz-se necessária a revisão da interpretação do INPI desta legislação, bastante restritiva.

O INPI tem a função de registrar os contratos de transferência de tecnologia para que produzam efeitos em relação a terceiros. Adicionalmente, o registro é condição precedente para a dedutibilidade dos pagamentos contratuais e para a remessa de pagamentos ao exterior. Como autarquia vinculada ao Ministério do Desenvolvimento, da Indústria e do Comércio Exterior (MDIC) a competência do INPI deriva da competência do próprio MDIC. A política do desenvolvimento da indústria, do comércio e dos serviços, bem como a 
propriedade intelectual e a transferência de tecnologia estão entre as atribuições do MIDC. ${ }^{546}$ O registro do contrato pelo INPI ocorre como parte da política industrial e tecnológica do MIDC. A sua atuação na transferência de tecnologia está vinculada à execução das normas de propriedade industrial considerando sua função econômica, social, técnica e jurídica e à execução de política industrial e tecnológica pelo poder Executivo. A atual política industrial e tecnológica do país é silente em relação à transferência de tecnologia internacional. A legitimação da atuação do INPI depende de uma sinalização explícita do MDIC na política industrial e tecnológica,

Ao Governo cabe delinear de forma mais clara em sua política industrial o tipo e maneira de controles que pretende exercer sobre a importação de tecnologia para o país, e com qual finalidade. Adicionalmente, é preciso promover uma harmonização dos vários diplomas legais incidentes na operação para que expressem coerência entre si. A coerência será atingida na medida em que se escolha os vetores definidores da regulação de forma consistente.

O terceiro argumento a corroborar a tese é o de que uma regulação eficaz, que incentive a transferência de tecnologia promovendo a absorção pela mão-de-obra local conseguirá se estabelecer com base no balanceamento entre proteção à propriedade industrial e preservação da concorrência. O instrumento adequado para tanto é a análise e interpretação dos efeitos para o mercado e para a sociedade dos termos contratuais pactuados.

Defendemos a implementação de instrumento de política industrial que foque na criação de normas técnicas e legais que promovam a importação, transferência e conseqüente difusão tecnológica, baseando-se em aspectos do direito da concorrência e do interesse coletivo, (i) conferindo competências específicas e claras ao INPI quando do registro dos contratos e (ii) influenciando a análise de condutas pelo Sistema Brasileiro de Defesa da Concorrência.

Verificamos no Capítulo I, Item 6.3, e no Capítulo III, Item 2, que nem mesmo o TRIPS, com seus padrões elevados de proteção à propriedade intelectual, logra impedir que o Brasil imponha regras e políticas específicas destinadas a incentivar a absorção de know-how pela mão-de-obra nacional: desde que se respeite em território nacional os direitos de

\footnotetext{
${ }^{546}$ Lei 10.683/03 e alterações, Art. 27 inc. IX alíneas a) e b).
} 
patente. ${ }^{547}$ Qualquer regulação de absorção de tecnologia protegida por segredo de negócio pela mão-de-obra local que se institua em território pátrio não representará violação aos termos do tratado.

Concluímos adicionalmente que as disposições sobre concorrência do TRIPS resultam de um compromisso entre países desenvolvidos e em desenvolvimento e são, portanto, uma exceção ou reserva à proteção da propriedade intelectual delineada no tratado. Referidas disposições refletem a aproximação baseada no mercado para a regulação da transferência de tecnologia. Assim, com o TRIPS a ênfase migrou da regulação de operações de transferência de tecnologia no interesse da parte mais fraca - normalmente a parte recipiente da tecnologia em um país em desenvolvimento - para um modelo baseado em um mercado aberto, no qual a transferência de tecnologia para países em desenvolvimento deva ser encorajada pela própria operação do mercado.

A fim de fornecer subsídios sobre possibilidades para a regulação da transferência de tecnologia, analisamos o tratamento dos contratos de transferência de tecnologia no espaço geográfico da Comunidade Européia. Percebemos que durante muitos anos o Regulamento de isenção em bloco para categorias de contratos de know-how e patentes foi editado justamente por reconhecer nesses contratos efeitos benéficos gerados pela inovação, mas ressalvava a necessidade de difusão do conhecimento internamente no espaço da Comunidade Européia (Regulamento 240/96) ${ }^{548}$. Delineava-se um controle baseado nas condutas sob os contratos. Em 2004, tem-se uma alteração de foco por meio do Regulamento 772/04. Ênfase é dada aos efeitos econômicos dos contratos, aproximando-se o enfoque europeu destas contratações do enfoque americano. ${ }^{549}$

\footnotetext{
${ }^{547}$ Vale ressaltar que o direito de patente é territorial, portanto, uma tecnologia patenteada em um determinado país, mas não no Brasil, não receberá qualquer proteção por propriedade intelectual em território nacional. Aliás, trata-se de tecnologia de conhecimento público, já que o patenteamento traz a público, mundialmente, a tecnologia, conforme analisamos no subitem 3, acima.

${ }^{548}$ Conforme o Item 3 do Preâmbulo: “(3) É conveniente unificar o âmbito de aplicação das referidas isenções por categoria num regulamento único de acordos de transferência de tecnologia, bem como harmonizar e simplificar o mais possível as disposições aplicáveis aos acordos de licença de patente e de saber-fazer, por forma a encorajar a divulgação dos conhecimentos técnicos na Comunidade e a promover o fabrico de produtos tecnicamente melhorados. (...)" (grifamos).

549 Conforme o Item 4 do Preâmbulo: "É conveniente renunciar à abordagem que consiste em enumerar as cláusulas isentas e dar maior ênfase à determinação das categorias de acordos isentos até um determinado nível de poder de mercado, bem como à identificação das restrições ou cláusulas que não podem constar desses acordos. Tal coaduna-se com uma abordagem de carácter económico que aprecia o impacto dos acordos no mercado relevante. É igualmente consentâneo com esta abordagem estabelecer uma distinção entre os acordos entre concorrentes e os acordos entre não concorrentes" Quanto ao enfoque americano: Antitrust Guidelines for the Licensing of Intellectual Property. Disponível em: <http://www.usdoj.gov/atr/public/guidelines/ipguide.htm>. Acesso em: 27/12/2009.
} 
Ullrich $^{550}$ distingue claramente entre a concorrência inovação e a concorrência disseminação que emerge nesse contexto.A política de concorrência focada no não impedimento da inovação se esquece de que o bônus que se concede hoje à inovação implicará um preço no futuro. A informação não é só efeito do seu processo de produção, a informação é também condição de seu processo de produção. Assim, a sociedade seria beneficiada se os competidores tivessem a permissão de aperfeiçoar a inovação, após utilizála.

Rodrik enfatiza que atualmente temos uma oportunidade histórica de tomar uma posição intermediária entre o intervencionismo estatal e a liberdade de iniciativa das forças de mercado. Enquanto as forças de mercado e o empreendedorismo individual continuariam a ser valorizados na agenda de política industrial, os governos teriam um papel estratégico de coordenação da esfera produtiva para além da simples garantia dos direitos de propriedade, execução dos contratos e estabilidade macroeconômica. ${ }^{551}$

Uma política de concorrência com a intenção de promover a disseminação e absorção de tecnologia não pode ser tarefa para as autoridades da área concorrencial, somente. Conforme relatório do ICTSD emitido dentro do "Programa de Direitos de Propriedade Intelectual e Desenvolvimento Sustentável”, “a implementação de uma política de concorrência eficaz tende a requerer uma multiplicidade de atores institucionais [...] cooperação e coordenação entre várias agências poderá ser essencial para criar e manter um ambiente competitivo." 552 O fortalecimento da edição de normativos pelo INPI, CADE, Ministérios envolvidos e pelo próprio Presidente da República, cada qual no exercício de sua capacidade normativa de conjuntura, delineando e sinalizando para o particular as diretrizes dos contratos de transferência de tecnologia de forma alinhada à conjuntura econômica então em vigor, é fundamental. O balanceamento ideal entre concorrência e propriedade industrial na transferência de tecnologia poderá ser alcançado desde que se adote um vetor comum e harmônico.

Ullrich atenta para a impopularidade da política de disseminação de conhecimentos vis-à-vis o charme que a política da inovação possui intrinsecamente:

\footnotetext{
${ }^{550}$ ULLRICH, H. Expansionist Intellectual Property Protection and Reductionist Competition Rules: a TRIPS Perspective, p. 751.

${ }_{551}^{55}$ RODRIK, D. Industrial Policy for the Twenty-First Century, p. 2.

${ }^{552}$ ICTSD - International Centre for Trade and Sustainable Development. Intellectual Property and Competition Law - Exploring Some Issues of Relevance to Developing Countries, p. 26.
} 
A alternativa inovação/disseminação em relação à política dos direitos de propriedade intelectual enfrenta um potencial conflito que lhe é próprio. Por conta do fato de a aproximação pela inovação ser mais popular quanto maior o mercado em que é aplicada, a colisão com a aproximação pela disseminação trará problemas de divisão territorial: a defesa da disseminação será muito provavelmente trazida por membros que são afetados especificamente pela dominância estrangeira da inovação. Assim, isto poderá fazer surgir um problema típico da globalização, em que o interesse de uma multinacional operando e se beneficiando de mercados transnacionais conflita com o interesse das nações de proteger e promover a indústria nos mercados locais. [...] Não se deve recorrer a falsas esperanças de que os conflitos entre os efeitos causados pelas duas orientações serão superados prontamente pela "concorrência regulatória" ou harmonização das regras. O problema de ambas as aproximações não é inerente a qualquer fraqueza teórica ou prática, mas sim e precisamente a sua orientação política. $^{553}$ (grifos nossos)

Num contexto de globalização econômica, o mesmo ordenamento jurídico que instrumentaliza políticas públicas também se presta a proteger interesses de agentes econômicos globais. A dificuldade que se impõe é a da escolha. Esperamos ter logrado expor os interesses envolvidos no contexto da regulação da contratação internacional de transferência de tecnologia a fim de contribuir efetivamente para a solução das questões atuais da difusão da tecnologia, da expansão do conhecimento e do desenvolvimento do país.

${ }^{553}$ ULLRICH, H. Expansionist Intellectual Property Protection and Reductionist Competition Rules: a TRIPS Perspective, p. 755. 


\section{REFERÊNCIAS BIBLIOGRÁFICAS}

ADKINS, B. The Draft Block Exemption: Opportunities and Threats. World Intellectual Property Report 2003(17).

AHRENS, C. Gewerblicher Rechtsschutz. Tübingen; Mohr Siebeck, 2008.

AMARAL JÚNIOR, A. do. Licença Compulsória e Acesso a Medicamentos nos Países em Desenvolvimento. Revista do Instituto dos Advogados de São Paulo, vol. 8, n. 16, p. 11-23 julho/dez. 2005.

ALTIN-SIEBER, I. Joint Ventures, Technologietransfer und - schutz. Heidelberg: Recht und Wirtschaft, 1996.

AMARAL, P. E. Função Social dos Contratos de Transferência de Tecnologia. Revista da $A B P I$, Rio de Janeiro, 2003(66).

ANDERSON, R. Competition policy and intellectual property rights in the knowledge-based economy. Calgary: University of Calgary Press, 1998.

ANDRADE, R. E. de. A Capacidade Normativa da Administração Pública. In: (org.). Regulação Pública da Economia no Brasil. Campinas: Edicamp, 2003.

ARRUDA, M. La Experiencia Brasileña en la Regulación de la Trasferencia de Tecnologia. Revista del Derecho Industrial, Buenos Aires, Depalma, 1982 (12).

ASCARELLI, T. Teoria della concorrenza e dei beni immateriali. Milano: Giuffrè, 1956.

ASCENSÃO, J. O. Direito Autoral. 2. ed. Rio de Janeiro: Renovar, 2007.

Direito de Autor e Desenvolvimento Tecnológico: Controvérsias e Estratégias. Revista Forense, Rio de Janeiro, 2005 (374). 
ASSAFIM, J. M. A Transferência de Tecnologia no Brasil Aspectos Contratuais e Concorrenciais da Propriedade Industrial. Rio de Janeiro: Lumen Juris, 2005.

ATAliBA, G. República e Constituição. São Paulo: Revista dos Tribunais, 1985.

AVELÃS NUNES, A. J. Industrialização e Desenvolvimento - A Economia Política do 'Modelo Brasileiro de Desenvolvimento. São Paulo: Quartier Latin, 2005.

BAER, W. A Economia Brasileira. São Paulo: Nobel, 2007.

BANCO MUNDIAL. Conhecimento e Inovação para a Competitividade. Trad. Confederação Nacional da Indústria. Brasília: CNI, 2008.

BAKER, J. B. Recent Developments in Economics that Challenge Chicago Shool Views. Antitrust Law Journal, 1989/58.

BARBOSA, C. R. Propriedade Intelectual Enquanto Informação e os Aspectos Econômicos dos Bens Intelectuais. Tese de Doutoramento. Universidade de São Paulo, Faculdade de Direito, 2007.

BARBOSA, D. B. Conceito Jurídico de Know-how (1979). Usucapião e Outros Estudos de Propriedade Intelectual. Rio de Janeiro: Lumen Juris, 2006.

BARBOSA, D. B. Direito da Inovação - Comentários à Lei N. 10973/2004, Lei Federal de Inovação. Rio de Janeiro: Lumen Juris, 2006.

. Propriedade Intelectual - A Aplicação do Acordo TRIPS. 2. ed. Rio de Janeiro: Lumen Juris, 2005.

. Uma Introdução à Propriedade Intelectual. 2. ed. Rio de Janeiro: Lumen Juris, 2003.

. A Tributação da Propriedade Industrial e do Comércio de Tecnologia. São Paulo: Revista dos Tribunais e INPI, 1984

BARTENBACH, K., GENNEN, K.; GAUL, D. Patentlizenz- und Know-how-Vertrag. 4. Aufl. Koeln: O. Schmidt, 1997. 
BASSO, M. Análise dos Direitos de Propriedade Intelectual sob a Perspectiva do Direito Antitruste: Especial Referência às Marcas. Revista do IBRAC 2009(1).

Contratos Internacionais do Comércio: Negociação, Conclusão, Prática. 3. ed. Porto Alegre: Livraria do Advogado Editora, 2002.

O Direito Internacional da Propriedade Intelectual. Porto Alegre: Livraria do Advogado Editora.

Propriedade Intelectual na Era pós-OMC., Porto Alegre: Livraria do Advogado Editora, 2005.

A Proteção Internacional dos Direitos de Propriedade Intelectual - das Uniões Internacionais à OMC-TRIPS, Tese de livre-docência. Faculdade de Direito da Universidade de São Paulo, 1999.

; SAlOMÃO FILHO, C.; POLIDO, F.; CÉSAR, P. Direitos de Propriedade Intelectual \& Saúde Pública. O acesso universal aos medicamentos anti-retrovirais no Brasil. Instituto de Direito do Comércio Internacional e Desenvolvimento (IDCID), 2007.

BASTOS, A. W. C. (organização e pesquisa). Dicionário Brasileiro de Propriedade Industrial e Assuntos Conexos. Rio de Janeiro: Lumen Juris, 1997.

Transferência de tecnologia: jurisprudência judicial e administrativa. Rio de Janeiro, Brasília: Fundação Casa de Rui Barbosa, 1981.

BENNETT, D.; VAIDYA, K. International Technology Transfer and Collaborative New Product Development: Evidence and a Case from the Machine Tool Industry. International Journal of Technology Transfer and Commercialisation 2002(1)

BENT, S.; GOTTS, I. Heightened Scrutiny of Intellectual Property Transfers by US Antitrust Officials is the Trend. European Intellectual Property Law Review 1994(6).

BLEEKE, J.; RAHL, J. The Value of Territorial and Field of Use Restrictions in the International Licensing of Unpatented Know-how: An Empirical Study. Northwestern Journal of International Law \& Business 1:450(1979). 
BODEWIG, T. On the Misuse of Intellectual Property Rights. In: HORST, A.; ROSENKRANZ, S. (Org.). Intellectual Property Rights and Global Competition - Towards a New Synthesis. Berlin: Sigma, 1995.

Neue Guidelines fuer Lizenzvertraege in den USA. GRUR Int. 1997(12).

BORK, R. Antitrust and Monopoly The Goals of Antitrust Policy. Antitrust and Monopoly American Economic Association.

BORK, R. The Antitrust Paradox - A Policy with the War Itself. New York: The Free Press, 1993.

The goals of antitrust policy. The American economic review 57 (1967).

BRAITHWAITE, J.; DRAHOS, P. Information Feudalism - Who Owns the Knowledge Economy? London: Earthscan Publications, 2002.

CABANELLAS, G. J. The extraterritorial effects of antitrust law on transfer of technology transactions. Weinheim, New York VCH Verlagsgesellschaft mbH, VCH Publishers Inc., 1991.

Antitrust and direct regulation of international transfer of technology transactions: a comparison and evaluation. Weinheim; Deerfield Beach, Florida; Basel, Verlag Chemie, 1984.

; MASSAGUER, J. Know-How Agreements and EEC Competition Law. Weinheim, New York VCH Verlagsgesellschaft mbH, VCH Publishers Inc.,1998.

CALABRESI, G. The Pointlessness of Pareto: Carrying Coase Further. The Yale Law Journal 1991(100).

CAMPANÁRIO, M. de A. Intenções Implícitas da Nova Política Industrial Brasileira. 2004. Material distribuído como leitura na disciplina "Política Industrial e Tecnológica", do Programa de Pós-Graduação da Faculdade de Economia e Administração da USP, em 2006.

; SILVA, M. M. Fundamentos de Uma Nova Política Industrial. In: FLEURY, M.T.L.; FLEURY, A. Política Industrial 1. São Paulo: Publifolha, 2004. 
; COSTA. T. R.; MUNIZ, M. M. Política Industrial, Tecnológica e de Comércio Exterior: Análise dos Fundamentos e Arranjos Institucionais. Palestra no IX Seminário Latino-Iberoamericano de Gestión Tecnológica - 25/28 Outubro de 2005.

CAPUTO, A. C.; DE MELO, H. A Industrialização Brasileira nos Anos de 1950: Uma Análise da Instrução 113 da Sumoc. Estudos Econômicos, São Paulo, 39(3): 513-538 jul.-set. 2009

CARVAlho, N. T. P. Abusos de Direitos de Patente: Um Estudo do Direito dos Estados Unidos com Referências Comparativas ao Direito Brasileiro. Revista da ABPI 1994(12).

Transferência de Tecnologia e Abuso de Poder Econômico - A Armadilha da L. 8.158/91 que o A.N. 120/93, do INPI, Finalmente Revelou. Revista da ABPI 1994(10), p. 21 e ss.

CASSESE, S. La Crisis Del Estado. Buenos Aires: Abeledo-Perrot, 2003.

- Las bases del derecho administrativo. Madrid: Instituto Nacional de Administración Pública, 1994.

CASSiOlATO, J. E.; ELIAS, L. A. O Balanço de Pagamentos Tecnológicos Brasileiro: Evolução do Controle Governamental e Alguns Indicadores. In: VIOTTI, E. B.; MACEDO, M. de M. (org.). Indicadores de Ciência, Tecnologia e Inovação no Brasil. Campinas: Ed. Unicamp, 2003.

CASTELlS, M. A Sociedade em Rede - A Era da Informação: Economia, Sociedade e Cultura Volume 1. 11. ed. São Paulo: Paz e Terra, 2008.

CHANG, H. Chutando a Escada - A Estratégia do Desenvolvimento em Perspectiva Histórica. São Paulo: Ed. Unesp, 2003.

CHENG.

Disponível em: $<$ http://www.nyls.edu/user_files/1/3/4/30/39/41/cheng_michigan.pdf>. Acesso em: 22/02/2010.

CHRISTOPH, M. Wettbewerbsbeschraenkungen in Lizenzvertraegen ueber gewerbliche Schutzrechte nach deutschem und europaeischem Recht. Regensburg, Roderer, 1998. 
COELHO, F. U. Reforma do Estado e Direito Concorrencial. In: SUNDFELD, C. A. Direito Administrativo Econômico. 1. ed. 3. tir. São Paulo, Malheiros, 2006.

COMPARATO, F. A Transferência Empresarial de Tecnologia para Países Subdesenvolvidos: um Caso Típico de Inadequação dos Meios aos Fins. Revista de Direito Mercantil, Industrial, Econômico e Financeiro 1982(47).

Ética. São Paulo: Companhia das Letras, 2006.

Muda Brasil - Uma Constituição para o desenvolvimento democrático. São Paulo: Editora Brasiliense, 1987.

CONDE GALLEGO, B. Handelsbezogene Aspekte des Lizenzkartellrechts. Bern: Staempfli, 2003.

The Principle of Exhaustion of Rights and Its Implications for Competition Law. IIC 2003(5).

CORREA, C. Aperfeiçoando a Eficiência Econômica e a Equidade pela Criação de Leis de Propriedade Intelectual. In: VARELLA, M. Propriedade Intelectual e Desenvolvimento. São Paulo: Aduaneiras, 2005.

CORREA, C. M. El derecho latinoamericano y la propuesta de regulación internacional de la transferência de tecnología: un análisis preliminar. 1981. Disponível em: $<$ http://www.iadb.org/intal/intalcdi/integracion_latinoamericana/documentos/057-

Derecho_de_la_Integracion_Estudios.pdf $>$.

Pro-Competitive Measures under TRIPS to Promote Technology Diffusion in Developing Countries. In: DRAHOS, P.; MAYNE, R. (Editores). Global Intellectual Property Rights. Nova Iorque: Palgrave Macmillan, 2002.

COSTA, T. R.; CAMPANÁRIO, M. A.; MUNIZ, M. M. Política Industrial, Tecnológica e de Comércio Exterior: Análise dos Fundamentos e Arranjos Institucionais. Palestra no IX Seminário Latino-Iberoamericano de Gestión Tecnológica - 25/28 Outubro de 2005

COUTINHO, L. Inflexões e Crise da Política Econômica: 1974-1980. Revista de Economia Política, São Paulo, Centro de Economia Política, 1981(1). 
DANEMANN; SIEMSEM; BIEGLER; IPANEMA MOREIRA. Comentários à Lei de Propriedade Industrial e Correlatos. Rio de Janeiro: Renovar, 2001.

DIAS, M. H. P. Hipertexto, O Labirinto Eletrônico, Uma Experiência Hipertextual. Tese de Doutoramento na Faculdade de Educação da Universidade Estadual de Campinas, Unicamp, 2000. Disponível em <http://www.libdigi.unicamp.br/document/?code=vtls000197594>. Acesso em 15/10/2009.

DICTIONNAIRE de Droit International Public, Emile Bruylant, Bruxelas, 2001.

DI PIETRO, M. S. Z. Direito Administrativo. São Paulo: Atlas, 1994.

DLOUHY, A. Extraterritoriale Anwendung des Kartellrechts im europaeischen und USamerikanischen Recht. Baden-Baden: Nomos-Verl.-Ges., 2003.

DOLMANS, M.; PIILOLA, A. The Proposed New Technology Transfer Block Exemption. World Competition 2003 26(4).

DRAHOS, P.; BRAITHWAITE, J. Information Feudalism - Who Owns the Knowledge Economy? London: Earthscan Publications, 2002.

DREXL, J. The Critical Role of Competition Law in Preserving Public Goods in Conflict with Intellectual Property Rights In: MASKUS, K.; REICHMAN, J. International Public Goods and Transfer of Technology under a Globalized Regime. Cambridge: Cambridge University Press, 2005.

DROMI, J. R. Derecho y Tecnologia. Revista de Direito Público, São Paulo, 1989(55).

DURAND, B.; GALARZA, A. F.; MEHTA, K. The Interface Between Copetition Policy and International Trade Liberalisation. Looking into the Future: Applying a New Virtual AntiTrust Standard, World Competition 27(1).

DWORKIN, R. A matter of principle; Cambridge/London: Harvard University Press, 1985.

ELIAS, L. A.; CASSIOLATO, J. E. O Balanço de Pagamentos Tecnológicos Brasileiro: Evolução do Controle Governamental e Alguns Indicadores. In: VIOTTI, E. B.; MACEDO, M. de M. (org.). Indicadores de Ciência, Tecnologia e Inovação no Brasil. Campinas: Ed. 
Unicamp, 2003.

ENCICLOPÉDIA SARAIVA do Direito. Coordenação. Limongi França. São Paulo: Saraiva, 1978.

FARINA, E. M. M. Q. Quatro Anos à Frente do CADE. Revista do IBRAC, São Paulo, 2009(16).

FEKETE, E. K. O Regime Jurídico do Segredo de Indústria e Comércio no Direito Brasileiro. Rio de Janeiro: Forense, 2003.

FERRAZ JR., T. Propriedade Industrial e Defesa da Concorrência. Revista da ABPI, Rio de Janeiro, 1993 Vol. II (8).

FIKENTSCHER, W. The Draft International Code of Conduct on the Transfer of Technology: A Study on 3. World Development. Weinheim; Deerfield Beach, Florida; Basel: Verlag Chemie, 1980.

Wettbewerb und gewerblicher Rechtsschutz. Muenchen: Berlin, Beck, 1958.

; HEINEMANN, A.; KUNZ-HALLSTEIN, H.P. Das Kartellrecht des Immaterialgueterschutzes im Draft International Antitrust Code, GRUR Int. 1995(10).

; STRAUB, W. Der RBP-Kodex der Vereinten Nationen: Weltkartellrichtlinien (II), GRUR Int. 1982(12)

FLORES, C. Segredo Industrial e o Know-how Aspectos Jurídicos Internacionais. Rio de Janeiro: Lumen Juris, 2008.

FORGIONI, P. A interpretação dos negócios empresariais no novo código civil brasileiro. Revista de Direito Mercantil 130, Ano XLLII abril/junho 2003, p. 7-38.

. Contrato de Distribuição. 2. ed. São Paulo: Revista dos Tribunais, 2008.

Direito Concorrencial e Restrições Verticais. São Paulo: Revista dos Tribunais, 2007. Os Fundamentos do Antitruste. 3. ed. São Paulo: Revista dos Tribunais, 2008. 
FRANCESCHINI, J. I. G. Os Contratos de Tecnologia como Forma de Abuso do Poder Econômico. Poder Econômico: Exercício e Abuso - Direito Antitruste Brasileiro. São Paulo: Revista dos Tribunais, 1985.

FRANCO, V. H. De M. Contratos de Transferência de Tecnologia: Intervenção Estatal e Tutela Legal. Revista de Direito Mercantil, São Paulo, ano VXIII (nova série) 1979(33).

FUNKE, G. Technologietransfer in internationalen Corporate Joint Ventures: eine Untersuchung zu dem Wirtschaftsordnungsrecht im Hinblick auf patentrechtlich nicht geschützte Technologie. Europäische Hochschulschriften: Reihe 2, Rechtswissenschaft, Band 2382. Frankfurt/M., Berlin, Bern, New York, Paris, Wien: Peter Lang, 1998.

FURTADO, C. Formação Econômica do Brasil. 32. ed. São Paulo: Companhia Editora Nacional, 2003.

FURTADO, C. Estado e Empresas Transnacionais na Industrialização Periférica. Revista de Economia Política, São Paulo, Centro de Economia Política, 1981(1).

GALARZA, A. F., MEHTA, K.; DURAND, B. The Interface Between Copetition Policy and International Trade Liberalisation. Looking into the Future: Applying a New Virtual AntiTrust Standard. World Competition 27(1), The Hague, Kluwer Law International, 2004.

GALBRAITH, JOHN K. O Novo Estado Industrial. Tradução da $3^{\text {a }}$ edição por Leônidas Gontijo Carvalho. São Paulo: Abril Cultural, 1982.

GALLINI, N.; TREBILCOCK, M. Intellectual Property Rights and Competition Policy: A Framework for the Analysis of Economic and Legal Issues. Competition Policy and Intellectual property Rights in the Knowledge-Based Economy. Ministry of Supply and Services, Canada. Calgary: University of Calgary Press, 1998.

GAMA CERQUEIRA, J. Tratado da Propriedade Industrial. 2. ed. São Paulo: Revista dos Tribunais, 1982.

GAUL, D., BARTENBACH, K.; GENNEN, K. Patentlizenz- und Know-how-Vertrag. 4. ed. Koeln: O. Schmidt, 1997.

GNOCCHI, A. Licenças e Roialties no Brasil. São Paulo: Revista dos Tribunais, 1960. 
GOMES, T. Z. Os Princípios da Ordem Econômica. Revista de Direitos Difusos 2004 (24).

GONÇALVES, M. E. dos Santos; A. C.; MARQUES, M. M. L. Direito Econômico. 4. ed. Coimbra: Almedina, 2001.

GONÇALVES, R. Globalização Produtiva, Investimento Externo Direto e Empresas Transnacionais no Brasil: Uma Perspectiva Histórica. 2008. Disponível em: <http://www. reggen.org.br/midia/documents/globaprodutivaivesextdireto.pdf>. Acesso em: dez. 2009.

GOTTS, I.; BENT, S. Heightened Scrutiny of Intellectual Property Transfers by US Antitrust Officials is the Trend. European Intellectual Property Law Review 1994(6).

GRANDSTRAND, O. The Economics and Management of Technology Trade: Towards a Pro-Licensing Era?. International Journal of technology Transfer and Commercialisation 2004(27).

GRAU, E. A Ordem Econômica na Constituição de 1988 (Interpretação e Crítica). 9. ed. São Paulo: Malheiros, 2004.

Equidade, Razoabilidade e Proporcionalidade. Revista do Advogado, ano XXIV, 78, setembro 2004.

. Ensaio e Discurso sobre a Interpretação/Aplicação do Direito. São Paulo: Malheiros, 2002.

Capacidade normativa de conjuntura. Enciclopédia Saraiva do Direito. São Paulo: Saraiva, 1977.

GRAU-KUNTZ, K. Sobre a Controvertida Questão da Patente Pipeline. Revista Eletrônica do IBPI, Edição Especial nov. 2009. Disponível em <www.ibpibasil.org>. Acesso em: 13/01/2010.

GRECO, M. A. Estabelecimento Tributário e Sites na Internet. In: LUCCA, N. de; SIMÃO FILHO, A. Direito \& Internet - Aspectos Jurídicos Relevantes. 2. ed. São Paulo: Quartier Latin, 2007 
GRIMES, W. Brand Marketing, Intrabrand Competition, and the Multibrand Retailer: The Antitrust Law of Vertical Restraints. Antitrust Law Journal 1995(64).

HASSELBLATT, G. (Hrsg.) Münchener Anwaltshanbuch Gewerblicher Rechtsschutz. Muenchen: Beck, 2005.

HAYEK, F. A. Individualism and Economic Order. Chicago: The University of Chicago Press, 1948.

HEINEMANN, A. Das Kartellrecht des geistigen Eigentums im TRIPS-Uebereinkommen der Welthandelsorganisation. GRUR Int. 1995(7).

Immaterialgueterschutz in der Wettbewerbsordnung: eine grundlagenorientierte Untersuchung zum Kartellrecht des geistigen Eigentums. Tuebingen: Mohr Siebeck, 2002.

; KUNZ-HALLSTEIN, H.P.; FIKENTSCHER, W. Das Kartellrecht des Immaterialgueterschutzes im Draft International Antitrust Code. GRUR Int. 1995(10).

HENN, G. Patent und Know-how Lizenzvertrag. 3. ed. Heidelberg: Recht und Wirtschaft, 1992.

HENN, R. Technologie, Wachstum und Beschaeftigung. Berlin, Heidelberg, New York, London, Paris, Tokyo: Springer Verlag, 1987.

HERDEGEN, M. Internationales Wirtschaftsrecht. 2. ed. Munique: Verlag C H Beck, 1995.

HIGUCHI, H. F. H.; HIGUCHI, C. H. Imposto de Renda das Empresas - Interpretação e Prática. 34. ed. São Paulo: IR Publicações, 2009.

HEUBEL, A. Technologietransfer durch internationale Unternehmenskooperationen - Eine vertragstheoretische Analyse Law and Economics, Band 23. München: Beck, 1994.

HOEKMAN, B.; JAVORCIK, B. Lessons from Empirical Research on International Technology Diffusion through Trade and Foreign Direct Investment. Global Integration and Technology Transfer. The International Bank for Reconstruction and Development/The World Bank. Washington: The World Bank and Palgrave Macmillan, 2006. 
HÖLZLWIMMER, G. Produkthaftungsrechtliche Risiken des Technologietransfers durch Lizenzverträge. Tese de Doutoramento na Ludwig-Maximiliams-Universität zu München. Munique, 1993.

ICTSD - International Centre for Trade and Sustainable Development. Intellectual Property and Competition Law - Exploring Some Issues of Relevance to Developing Countries. Issue Paper 21. Geneva, 2007.

IMMENGA, U.; MESTMAECKER, E. J. GWB Gesetz gegen Wettbewerbsbeschraenkungen Kommentar. 3. ed. Muenchen: Beck, 2001.

IRTI, N. A Ordem Jurídica do Mercado. Palestra proferida no seminário: O Estado, A Empresa e o Mercado - Novas Tendências do Direito Econômico e Comercial - ministrado na Faculdade de Direito da Universidade de São Paulo, em 10/09/2007 - resenha distribuída aos presentes.

IRTI, N. L’ètá della Decodificazione. Milano: Giuffré, 1999.

JAVORCIK, B.; HOEKMAN, B. Lessons from Empirical Research on International Technology Diffusion through Trade and Foreign Direct Investment. Global Integration and Technology Transfer. The International Bank for Reconstruction and Development/The World Bank. Washington D.C.: The World Bank and Palgrave Macmillan, 2006.

JUNQUEIRA DE AZEVEDO, A. Negócio Jurídico - Existência, Validade e Eficácia. 2. ed. São Paulo: Saraiva, 1986.

KALLAY, D. The Law and Economics of Antitrust and Intellectual Property - An Austrian Approach. Cheltenham/Northampton: Edward Elgar Publishing, 2004.

KATTAN, J. Trends in Intellectual Property Antitrust Enforcement. Antitrust Magazine American Bar Association, Summer 1997.

KORAH, V. Draft Block Exemption for Technology Transfer. European Competition Law Review 2004(5).

KOROTTCHENKO DE OLIVEIRA, A. Inovação Tecnológica: Opinião. Estado de Minas, Belo Horizonte, 10 de janeiro de 2009. 
KUBRUSLY, C. T. Direito Antitruste e Propriedade Intelectual: Análise Concorrencial dos Acordos de Licença e da Recusa de Licenciar. Dissertação de Mestrado. Faculdade de Direito da Universidade de São Paulo, 2008.

KUNZ-HALlSTEIN, H. P.; HEINEMANN, A.; FIKENTSCHER, W. Das Kartellrecht des Immaterialgueterschutzes im Draft International Antitrust Code. GRUR Int. 1995(10).

LABRUNIE, J. Direito de Patentes - Condições Legais de Obtenção e Nulidades. Barueri: Manole, 2006.

A Proteção ao Segredo de Negócio. In: SIMÃO FILHO, A.; LUCCA, N. (coord.) Direito Empresarial Contemporâneo. 2. ed. São Paulo: Juarez de Oliveira, 2004.

A Transferência de Tecnologia ao Exterior. Gazeta Mercantil, Caderno A4 p. 9, $30 / 10 / 2007$.

; MURAD, F. Apontamentos sobre o Contrato de Cost Sharing e sua Tributação. Revista da ABPI 2004(71).

LANDES, W. M.; POSNER, R. A. The Economic Structure of Intellectual Property Law. Cambridge, Massachussets e Londres: The Belknap Press of Harvard University Press, 2003.

LANGE, K. Europäisches und Deutsches Kartellrecht. Frankfurt am Main: Verlag Recht und Wirtschaft, 2006.

LARENZ, K. Metodologia da Ciência do Direito. 2. ed. Lisboa: Fundação Calouste Gulbekian, 1983.

LEONARDOS, G. A Tributação da Transferência de Tecnologia. Rio de Janeiro: Forense, 1997.

LEONARDOS, L. Tratamento do Fluxo de Tecnologia Frente à Nova Lei de Propriedade Industrial e ao TRIPS. Revista da ABPI 2000(47).

LESSA, C. Prefácio. In: TAVARES, M. C. Da Substituição de Importações ao Capitalismo Financeiro Ensaios sobre Economia Brasileira. Rio de Janeiro: Zahar Editores, 1972. 
LIND, R.; MUYSERT, P. The European Commission`s Draft Technology Transfer Block Exemption Regulation and Guidelines: A Significant Departure from Accepted Competition Policy Principles. European Competition Law Review 2004(4).

MARQUES, M. M. L.; GONÇALVES, M. E.; SANTOS, A. C. dos. Direito Econômico 4. ed. Coimbra: Almedina, 2001.

MARTINEK, M. Moderne Vertragstypen, Band II: Franchising, Know-how Verträge, Management- und Consultingverträge. Munique: Beck, 1992.

MASSAGUER, J.; CABANELLAS, G. Know-How Agreements and EEC Competition Law. Weinheim, New York: VCH Verlagsgesellschaft mbH, VCH Publishers Inc., 1991.

MATTIA, F. de. O Direito de Autor e a Concorrência Desleal. Revista de Direito Mercantil, 1995(20).

MEHTA, K.; DURAND, B.; GALARZA, A. F. The Interface Between Copetition Policy and International Trade Liberalisation. Looking into the Future: Applying a New Virtual AntiTrust Standard. World Competition 2004 27(1).

MÉLEGA, L. Contrato de Prestação de Assistência Técnica - Sua Averbação junto ao Instituto Nacional da Propriedade Industrial como Condição à Dedutibilidade das Despesas Respectivas para Efeito da Apuração do Lucro Tributável. Revista de Direito Mercantil, 1975(19).

MELO, H. de; CAPUTO, A. C. A Industrialização Brasileira nos Anos de 1950: Uma Análise da Instrução 113 da Sumoc. Estudos Econômicos, São Paulo, 39(3): 513-538 jul.-set. 2009.

MELLO, C. A. B. de. Curso de Direito Administrativo. 9. ed. São Paulo: Malheiros, 1997.

MESTMÄCKER, E. A Legal Theory without Law - Posner v. Hayek on Economic Analysis of Law. Beiträge zur Ordnungstheorie und Ordnungspolitik 174 Herausgegeben vom Walter Eucken Institut. Tübingen: Mohr Siebeck, 2007.

Die Interdependenz von Recht und Ökonomie in der Wettbewerbspolitik. Wirtschaft und Verfassung in der Europäischen Union Beiträge zu Recht, Theorie und Politik der europäischen Integration. 2. Auflage. Baden Baden: Nomos, 2006. 
Europäisches Wettbewerbsrecht. München: Beck, 1974.

. J.; IMMENGA, U. GWB Gesetz gegen Wettbewerbsbeschraenkungen Kommentar. 3 Aufl. München: Beck, 2001.

MORI, R. Política Fiscal e Desempenho Macroeconômico. In: VASCONCELLOS, R. F. de (coord.). Direito Tributário: Política Fiscal (série GVLaw). Saraiva: São Paulo, 2009.

MORO, M. C. F. Marcas Tridimensionais - Sua Proteção e os Aparentes Conflitos com a Proteção Outorgada por Outros Institutos da Propriedade Intelectual. São Paulo: Saraiva; 2009.

MUNIZ, M. M.; COSTA. T. R.; CAMPANÁRIO, M. A. Política Industrial, Tecnológica e de Comércio Exterior: Análise dos Fundamentos e Arranjos Institucionais. Palestra no IX Seminário Latino-Iberoamericano de Gestión Tecnológica - 25/28 Outubro de 2005.

MURAD, F.; LABRUNIE, J. Apontamentos sobre o Contrato de Cost Sharing e sua Tributação. Revista da ABPI 2004(71).

MUYSERT, P.; LIND, R. The European Commission's Draft Technology Transfer Block Exemption Regulation and Guidelines: A Significant Departure from Accepted Competition Policy Principles. European Competition Law Review 2004(4).

NGUYEN, T. T. The CFI's Ruling in Microsoft v. Commission. IIC, vol. 39 5/1002, 1998, p. 558-586.

NORTH, D. C. Privatization, Incentives and Economic Performance. 1994. Disponível em: <http://ideas.repec.org/p/wpa/wuwpeh/9411002.html>. Acesso em: 18/02/2010.

NORTH, D. C. A Recommendation on How to Intelligently Approach Emerging Problems in Intellectual Property Systems. Review of Law and Economics, vol. 5, iss. 3, Article 9, 2009. Disponível em: <http//www.bepress.com/rle/vol5/iss3/art9>. Acesso em: 05/01/2010

NUSDEO, F. Curso de Economia - Introdução ao Direito Econômico.; 4. ed. São Paulo: Revista dos Tribunais, 2005. 
OCDE - Diretrizes para Empresas Multinacionais. Disponível em: $<$ http://www.fazenda.gov.br/sain/pcnmulti/diretrizes.asp\#concorrencia>. Acesso em: 19/02/2010.

OLIVEIRA, R. M. de. Royalties e Assistência Técnica, Científica, Administrativa ou Semelhante. Guia IOB Imposto de Renda Pessoa Jurídica, São Paulo, Thomson IOB, 2008.

PACHECO, P. El Analisis Econômico del Derecho. Madrid: Centro de Estúdios Constitucionales, 1994.

PACK, H. The Cost of Technology Licensing and the Transfer of Technology. International Journal of Technology Transfer and Commercialisation 2002(1).

PAIVA, P. Colloreconomics. Revista Brasileira de Economia, Rio de Janeiro, Fundação Getúlio Vargas, 1991(45).

PEDREIRA, J .L. B. Imposto Sobre a Renda - Pessoas Jurídicas. Vol I. Rio de Janeiro: Justec, 1979.

PEEPERKORN, L. IP Licences and Competition Rules: Striking the Right Balance. World Competition 26(4).

PEREIRA, L. C. B. Os Dois Congelamentos de Preços no Brasil. Revista de Economia Política, São Paulo, Centro de Economia Política, 1988(8).

PIILOLA, A.; DOLMANS, M. The Proposed New Technology Transfer Block Exemption. World Competition 2003 26(4).

POLANYI, K. A Grande Transformação - As Origens de Nossa Época. Rio de Janeiro: Elsevier, 2000.

PONTES DE MIRANDA. Tratado de Direito Privado. Parte Especial. Tomos XVI e XVII. Campinas: Bookseller, 2002.

POSNER, R. The Chicago School of Antitrust Analysis. University of Pennsylvania Law Review 1979(127). 
The Next Step in the Antitrust Treatment of Restricted Distribution: Per Se Legality. The University of Chicago Law Review 1981(48).

; LANDES, W. M. The Economic Structure of Intellectual Property Law. Cambridge, Massachussets e Londres: The Belknap Press of Harvard University Press, 2003.

POSSAS, Mario Luiz. Limites normativos da análise econômica antitruste. Revista do IBRAC 2009(1)

PRADO, M. C. A. Contrato Internacional de Transferência de Tecnologia. Porto Alegre: Livraria do Advogado Editora, 1997.

PROENÇA, J. M. M. Concentração Empresarial e o Direito da Concorrência. São Paulo: Saraiva, 2001.

RAHL, J.; BLEEKE, J. The Value of Territorial and Field of Use Restrictions in the International Licensing of Unpatented Know-how: An Empirical Study. Northwestern Journal of International Law \& Business 1:450(1979).

REBEL, D. Gewerbliche Schutzrechte. Koeln: Berlin, Bonn, Muenchen, Carl Heymmans, 2003.

REMÉDIO MARQUES, J. P. Propriedade Intelectual e Interesse Público. Boletim da Faculdade de Direito da Universidade de Coimbra, Lisboa, 2003, Vol. LXXIX.

REMICHE, B. Revolução Tecnológica, Globalização e Direito das Patentes. In: VARELLA, M. Propriedade Intelectual e Desenvolvimento, São Paulo: Aduaneiras, 2005.

REPERTÓRIO ENCICLOPÉDICO do Direito Brasileiro. Por J. M. De Carvalho Santos coadjuvado por José de Aguiar Dias. Rio de Janeiro: Borsoi.

RIBEIRO, R. P.; VASCONCELLOS, R. F. A Transferência Internacional de Tecnologia e sua Tributação. Revista de Direito Tributário Internacional, São Paulo, Quartier Latin, 2007(6).

RODRIK, D. Industrial Policy for the Twenty-First Century. September 2004. Disponível em: <http://www.ksg.harvard.edu/rodrik>. Acesso em: 18/08/2008. 
ROSENBERG, B. Patentes de Medicamentos e Comércio Internacional: os parâmetros do TRIPS e do direito concorrencial para a outorga de licenças compulsórias. Tese de Doutorado apresentada na Faculdade de Direito da Universidade de São Paulo em 2004.

ROUBIER, P. Le Droit de la Proprieté Industrielle. Vol. 1. Paris: Sirey, 1952.

SACHS, J. O Divisor Global de Inovação. In: VARELLA, M. Propriedade Intelectual e Desenvolvimento. São Paulo: Aduaneiras, 2005.

SALOMÃO FILHO, C. Direito Concorrencial - As Condutas. São Paulo: Malheiros, 2003. Direito Concorrencial - As Estruturas. 3. ed. São Paulo: Malheiros, 2007.

Direito Industrial, Direito Concorrencial e Interesse Público. Revista CEJ, Brasília, 2006(35).

. Regulação e Desenvolvimento. São Paulo: Malheiros, 2002.

A Regulação da Atividade Econômica (Princípios e Fundamentos Jurídicos). 2. ed. São Paulo: Malheiros, 2008.

Sociedade Anônima: Interesse Público e Privado. Revista de Direito Mercantil, São Paulo, 127:12; 2002.

SANTOS, M. J. P. dos. A Proteção Autoral de Programas de Computador. Rio de Janeiro: Lumen Juris, 2008.

SANTOS, A. C. dos; GONÇALVES, M. E.; MARQUES, M. M. L. Direito Econômico. 4. ed. Coimbra: Almedina, 2001.

SCHOUERI, L. E. Normas Tributárias Indutoras e Intervenção Econômica. Rio de Janeiro: Forense, 2005.

SCHUMPETER, J. A. Capitalism, Socialism and Democracy. New York: Harper Colophon, 1975.

Das Wesen und der Hauptinhalt der theoretischen Nationaloekonomie. 2. Aufl. Berlin: Duncker \& Humblot, 1970. 
Theorie der wirschaftlichen Entwicklung. 4. ed. Berlin: Duncker \& Humblot, 1934. Reimpressão em 1997 como 9. ed., inalterada em relação à 4. ed.

SEGADE, J. El Secreto Industrial (Know-how): Concepto y Protección. Madri: Tecnos, 1974.

SEN, A. Development as Freedom. Oxford: Oxford University Press, 1999.

SHAVELL, S.; TANGUY VAN YPERSELE, T. Rewards versus intellectual property rights. Working Paper 6956, National Bureau of Economic Research. Cambridge: February 1999. Disponível em <http://nber.org/papers/w6956>.

SHIEBER, B. M. Abusos do Poder Econômico: Direito e Experiência Anti-truste no Brasil e nos E.U.A. São Paulo: Revista dos Tribunais, 1966.

SILVEIRA, N. A Propriedade Intelectual e as Novas Leis Autorais. São Paulo: Saraiva, 1998. Estudos e Pareceres de Propriedade Intelectual. Organização e Seleção de Wilson Silveira. Rio de Janeiro: Lumen Juris.

INPI - Transferência de Tecnologia - Leis 5.648/70 e 5/772/71 - Averbação de contrato no INPI. Revista de Direito Mercantil 1984(54).

Propriedade Intelectual: Propriedade Industrial, Direito de Autor, Software, Cultivares. 3. ed. Barueri: Manole.

Licença de Exploração de Patentes com Cláusula Acessória de Assistência Técnica - Royalties Contratados em Fraude à Lei. Revista de Direito Mercantil, n. 63 julho/setembro 1986(63).

STAHL, K. Konferenz der Vereinten Nationen ueber wettbewebsbeschraenkende Geschaeftspraktiken im internationalen Handel. Wettbewerb und Wirtschaft 1980(4).

STIGLER, G. A Note on Patents. The Organization of Industry. Homewood, Nobleton: Ricahrd D. Irwin, Inc.; Irwin-Dorsey Limited, 1968. 
STIGLITZ, J. Development Policies in a World of Globalization. Paper presented on the occasion of the fiftieth anniversary of the Brazilian Economic and Social Development Bank (BNDES). Rio de Janeiro, September 2002.

STRAUB, W.; FIKENTSCHER, W. Der RBP-Kodex der Vereinten Nationen: Weltkartellrichtlinien (II). GRUR Int. 1982(12).

STUMPF, H. Der Lizenzvertrag. 5. ed. Heidelberg: Recht und Wirtschaft, 1984.

SUZIGAN, W. Estado e Industrialização no Brasil. Revista de Economia Política, São Paulo, Centro de Economia Política, 1988(8).

TANGUY VAN YPERSELE, T.; SHAVELL, S. Rewards versus intellectual property rights. Working Paper 6956, National Bureau of Economic Research, Cambridge, February 1999. Disponível em: <http://nber.org/papers/w6956>.

TAVARES, M. O Processo de Substituição de Importações como Modelo de Desenvolvimento na América Latina. Da Substituição de Importações ao Capitalismo Financeiro Ensaios sobre Economia Brasileira. Rio de Janeiro: Zahar, 1972.

TERHECHTE, J.P. Die Reform des europaeischen Kartellrechts - am Ende eines langen Weges? Europaeische Zeitung fuer Wirtschaftsrecht 2004(12).

TINOCO SOARES, J. C. Lei de Patentes, Marcas e Direitos Conexos. São Paulo: Revista dos Tribunais, 1997.

TORRES, H. T. Propriedade Industrial e Transferência de Tecnologia no Direito Tributário Brasileiro. Repertório de Jurisprudência IOB, 2004(15), volume I.

TREBILCOCK, M.; GALLINI, N. Intellectual Property Rights and Competition Policy: A Framework for the Analysis of Economic and Legal Issues. Competition Policy and Intellectual property Rights in the Knowledge-Based Economy, Ministry of Supply and Services, Canada. Calgary: University of Calgary Press, 1998.

ULLRICH, H. Expansionist Intellectual Property Protection and Reductionist Competition Rules: a TRIPS Perspective. In: MASKUS, K.; REICHMAN, J. International Public Goods 
and Transfer of Technology under a Globalized Regime. Cambridge: Cambridge University Press, 2005.

UNCTAD - United Nations Conference on Trade and Development. Set of Multilaterally Agreed Equitable Principles and Rules for the Control of Restrictive Business Practices. United Nations Publication. New York and Geneva, 2000. Disponível em: <http://www.unctad.org/en/docs/tdrbpconf10r2.en.pdf> Acesso em: 19/02/2010.

UNCTAD - United Nations Conference on Trade and Development. The Least Developed Countries Report 2007 Knowledge, Technological Learning and Innovation for Development. United Nations Publication. New York and Geneva, 2007. Versão compilada disponível em $<$ http//:www.unctad.org $>$.

UNCTAD - United Nations Conference on Trade and Development. Transfer of Technology. United Nations Publication. New York and Geneva, 2001. Disponível em: $<$ http://www.unctad.org/en/docs//psiteiitd28.en.pdf>. Acesso em: 20/01/2010.

UNCTAD - ICTSD - United Nations Conference on Trade and Development, International Centre for Trade and Sustainable Development. Intellectual Property Rights: Implications for Development - Policy Discussion Paper. Geneva, UNCTAD, ICTSD, 2003. Disponível em: $<$ http//:www.icstd.org/iprsonline $>$.

VAIDYA, K.; BENNETT, D. International Technology Transfer and Collaborative New Product Development: Evidence and a Case from the Machine Tool Industry. International Journal of Technology Transfer and Commercialisation 2002(1).

VASCONCELLOS, R. F.; RIBEIRO, R. P., A Transferência Internacional de Tecnologia e sua Tributação. Revista de Direito Tributário Internacional, São Paulo, 2007(6).

VAZ e DIAS, J. C. Os Princípios da Legalidade e da Competência e os Limites de Atuação do INPI no Direito da Concorrência. Revista do IBRAC, 9, 1998, p. 12-21.

VIEGAS, J. Dos Contratos de Transferência de Tecnologia sob o Regime da Nova Lei de Propriedade Industrial. Revista da ABPI, Rio de Janeiro, 1998(34). 
Contratos Típicos de Propriedade Industrial: Contratos de Cessão e de Licenciamento de Marcas e Patentes; Licenças Compulsórias. In: Dos SANTOS, M. J. P.; JABUR, W. P. (coord.). Propriedade Intelectual: Contratos de Propriedade Industrial e Novas Tecnologias (série GVLaw). Saraiva: São Paulo, 2007.

VILLASCHI, A. Anos 90 - Uma década perdida para o sistema nacional de inovação brasileiro? São Paulo em Perspectiva, São Paulo, v. 19, n. 2, p. 3-20 abr./jun., 2005.

WEISZ, J. Mecanismos de Apoio à Inovação Tecnológica. 3. ed. Brasília: SENAI/DN, 2006.

WHITE, B. Black and White Thinking in the Gray Areas of Antitrust: Dismantling of Vertical Restraints Regulation. The George Washington Law Review 1991(60). 